\title{
MODERNIZAÇÃO AGRÍCOLA EM PERNAMBUCO, 1950-1996
}

\author{
WILLIAM JOSÉ SABBAG
}

Orientador: Prof. Dr. GERALDO SANT'ANA DE CAMARGO BARROS

Tese apresentada à Escola Superior de Agricultura

"Luiz de Queiroz", Universidade de São Paulo, para obtenção do título de Doutor em Ciências. Área de concentração: Economia Aplicada.

\section{PIRACICABA}

Estado de São Paulo - Brasil

Outubro - 2000 
Dados Internacionais de Catalogação na Publicação (CIP) DIVISĀO DE BIBLIOTECA E DOCUMENTAÇÃO - Campus "Luiz de Queiroz"/USP

Sabbag, Willian José

Modemização agrícola em Pernambuco 1950-1996 / William José Sabbag. - Piracicaba, 2000.

$170 \mathrm{p}$.

Tese (doutorado) - Escola Superior de Agricultura Luiz de Queiroz, 2000.

Bibliografia.

1. Análise fatorial 2. Desenvolvimento agrícola 3. Modernização agrícola 4. Tecnologia agrícola I. Título

CDD 338.16

Parmitich cópia total ou parcial destedocumento, desde que citada a fonte- O autory 


\section{SUMÁRIO}

Página

LISTA DE FIGURAS ......................................................................... iv

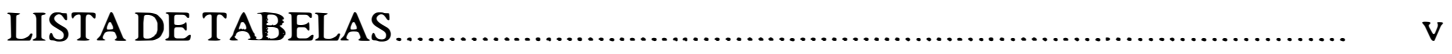

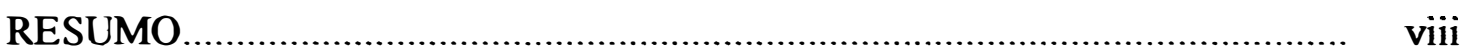

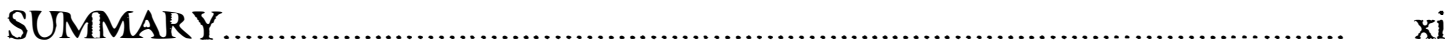

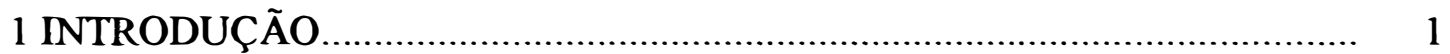

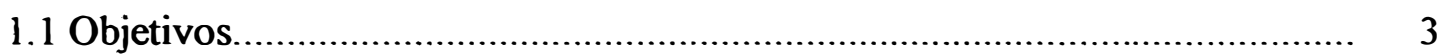

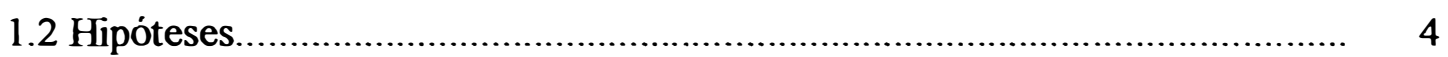

1.3 Organização do trabalho........................................................................... 5

2 MODERNIZAÇÃO D A AGRICULTURA ................................................ 7

2.10 conceito de modernização....................................................................... 7

2.2 Modelos teóricos sobre o desenvolvimento da agricultura........................ 12

2.2.1 Pressupostos teóricos sobre o desenvolvimento em economias dualistas.... 17

2.3 Dualismo na agricultura pernambucana................................................. 24

3 CARACTERIZAÇÃO DA MODERNIZAÇÃO AGRÍCOLA EM

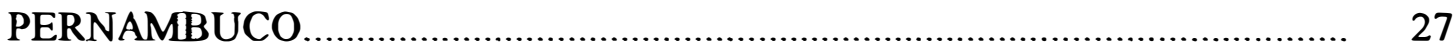

3.1 A modernização na Mesorregião da Mata ................................................. 33

3.2 A modemização na Mesorregião Agreste...................................................... 38

3.3 A modemização na Mesorregião Sertão................................................... 41

4 ESTUDOS EMPÍRICOS SOBRE MODERNIZAÇÃO ATRAVÉS DA

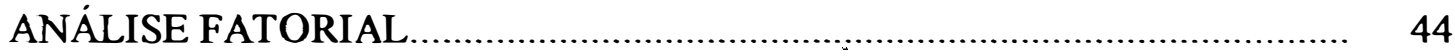

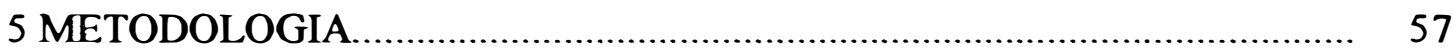

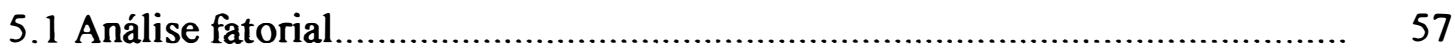

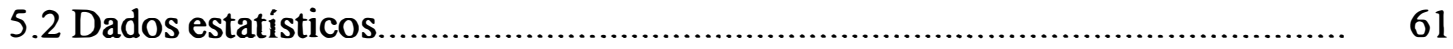

5.2.1 Variáveis utilizadas nas análises fatoriais................................................ 67

5.3 Teste dos indicadores (Análise fatorial estática para 1960 e 1980).............. 71 
5.3.1 Indicadores de modernização utilizados para teste na análise fatorial

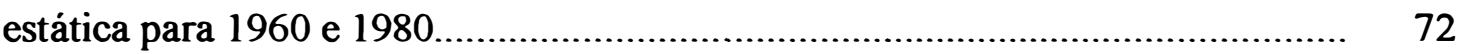

5.4 Análise fatorial dinâmica para o periodo 1950/1960/1970/1980.................. 74

5.4.1 Dados estatísticos referentes aos indicadores de modernização para a análise dinâmica.

5.4.2 Indicadores de modernização para a análise dinâmica do período $1950 / 80$

5.5 Análise fatorial estática para 1995/96.

5.5.1 Indicadores de modernização para a análise estática de1995/96.

6 RESULTADOS PRELIMINARES E DISCUSSÃO DO TESTE DOS INDICADORES

6.1 Análise estática da modernização agrícola nas $12 \mathrm{MRHs}$ do Estado de Pernambuco em 1960

6.2 Análise estática da modernização agricola nas 12 MRHs do Estado de Pernambuco em 1980.

6.3 Conclusões

7 RESULTADOS E DISCUSSÃO

7.1 Análise dinâmica da modernização agrícola nas 12 MRHs do Estado de Pernambuco no periodo 1950/1980.

7.2 Análise estática da modernização agrícola no Estado de Pernambuco segundo dados de 1995/1996

8 CONCLUSÕES. 


\section{LISTA DE FIGURAS}

Página

7.1 Tendências do Fator 3 (mecanização) nas microrregiões canavieiras entre 1950 e 1980.

7.2 Tendências do Fator 3 (mecanização) na Mesorregião Agreste entre 1950 e 1980

7.3 Tendências do Fator 3 (mecanização) na Mesorregião Sertão entre 1950 e 1980

7.4 Tendências do Fator 1 (tração animal) e do Fator 3 (mecanização) nas microrregiões Arcoverde, Sertão do Moxotó e Alto Pajeú entre 1950 e 1980

7.5 Tendências do Fator 1 (tração animal) e do Fator 3 (mecanização) nas microrregiões Agreste Meridional, Vale do Ipojuca e Araripina entre 1950 e 1980

7.6 Tendências do Fator 1 (tração animal) e do Fator 3 (mecanização) nas microrregiões Sertão do São Francisco e Salgueiro entre 1950 e 1980.

7.7 Tendências do Fator 1 (tração animal) e do Fator 3 (mecanização) nas microrregiões Recife, Mata Seca e Mata Úmida entre 1950 e 1980

7.8 Tendências do Fator 1 (tração animal) e do Fator 3 (mecanização) na microrregião Agreste Setentrional entre 1950 e 1980. 


\section{LISTA DE TABELAS}

Página

3.1 Área colhida, quantidade e rendimento médio, segundo culturas. Pernambuco, 1950/1980.

3.2 Distribuição percentual do valor bruto da produção vegetal segundo o tipo e a destinação da produção. Pernambuco, 1950/79.

3.3. Distribuição percentual do crédito de custeio entre os principais produtos agrícolas. Pernambuco, 1974/81

3.4. Valor médio por contrato de crédito para os principais produtos agrícolas de Pernambuco, segundo quadriênios (1974-77; 1978-81) e o período 1974-81.. 3.5 Distribuição percentual do crédito destinado à aquisição de insumos subsidiáveis entre os principais produtos agrícolas. Pernambuco, 1974-81......... 3.6 Distribuição percentual da área cultivada com tomate, cebola e alho, segundo mesorregiões de Pernambuco. 1949-80

4.1 Valores das componentes principais, segundo microrregiões homogêneas, na análise fatorial em 20 indicadores estratificados. Pernambuco, 1970-72......... 4.2 Valores de dois fatores principais obliquos, segundo microrregiões homogêneas, na análise fatorial em 20 indicadores estratificados. Pernambuco, 1970-72.

4.3 Valores de três fatores imagem, segundo microrregiões homogêneas, na análise fatorial em 20 indicadores estratificados. Pernambuco, 1970-72 ............ 4.4 Valores de cinco fatores principais oblíquos, segundo microrregiões homogêneas, na análise fatorial em 20 indicadores estratificados. Pernambuco, 1970-72.

4.5 Valores de três fatores de modemização segundo microrregiões de Pernambuco, 1980.

5.1 Equivalência aproximada entre microrregiões homogêneas (Censos de 1970 ao de 1985) e zonas fisiográficas (Censos de 1950 e 1960) para o Estado de Pernambuco.

5.2 Equivalência aproximada entre as microrregiões homogêneas do Censo Agropecuário de 1995/1996 e as microrregiões dos Censos do período 1970 a 1985 para o Estado de Pernambuco.

5.3 Existência de variáveis específicas nos Censos de 1950 e 1960..................... 68

5.4 Significado dos conceitos de área trabalhada, explorada e aproveitável........ 69

5.5 Pesos para conversão das categorias de trabalhador, segundo sexo e idade, em equivalente-homem. 
6.1 Raízes características da matriz de correlações simples $(35 \times 35)$ para as microrregiões homogêneas do Estado de Pernambuco, 1960.

6.2 Coeficientes de correlação (cargas fatoriais), comunalidades e percentagem da variância explicada por cada fator após a rotação pelo método Varimax. Microrregiões Homogêneas do Estado de Pernambuco, 1960.

6.3 Percentagem da variância explicada por cada fator antes e após a rotação ortogonal.

6.4 Percentagem de grupos de variáveis segundo o grau de correlação entre cada fator e a variável.

6.5 Valores dos fatores, segundo microrregiões homogêneas, na análise fatorial em 35 indicadores. Pernambuco, 1960.

6.6 Raízes características da matriz de correlações simples $(35 \times 35)$ para as microrregiões homogêneas do Estado de Pernambuco, 1980.

6.7 Percentagem da variância explicada por cada fator antes e após a rotação ortogonal.

6.8 Coeficientes de correlação (cargas fatoriais), comunalidades e percentagem da variância explicada por cada fator após a rotação pelo método Varimax. Microrregiões Homogêneas do Estado de Pernambuco, 1980.

6.9 Percentagem de grupos de variáveis segundo o grau de correlação entre a variável e cada fator.

6.10 Valores dos fatores, segundo microrregiões homogêneas, na análise fatorial em 35 indicadores. Pernambuco, 1980.

7.1 Raízes caracteristicas da matriz de correlações simples ( $25 \times 25)$ para as microrregiões homogêneas do Estado de Pernambuco, 1950/1980.

7.2 Coeficientes de correlação (cargas fatoriais), comunalidades e percentagem da variância explicada por cada fator após a rotação pelo método Varimax, na extração de três fatores em 25 indicadores. Microrregiões Homogêneas do Estado de Pernambuco, 1950 a 1980

7.3 Percentagem da variância explicada por cada fator antes e após a rotação ortogonal......

7.4 Coeficientes de correlação (cargas fatoriais), comunalidades e percentagem da variância explicada por cada fator após a rotação pelo método Varimax, na extração de quatro fatores em 25 indicadores. Microrregiões Homogêneas do Estado de Pernambuco, 1950 a 1980

7.5 Percentagem de grupos de variáveis segundo o grau de correlação entre cada fator e a variável.

7.6 Valores do Fator 1 (tração animal), segundo microrregiões homogêneas, na análise fatorial em 25 indicadores. Pernambuco, 1950 a 1980.

7.7 Variação $(\Delta)$ dos valores do Fator 1 (tração animal), segundo microrregiões homogêneas, na análise fatorial em 25 indicadores. Pernambuco, 1950 a 1980... 7.8 Valores do Fator 2 (pecuária melhorada), segundo microrregiões homogêneas, na análise fatorial em 25 indicadores. Pernambuco, 1950 a 1980... 
7.9 Variação $(\Delta)$ dos valores do Fator 2 (pecuária melhorada), segundo microrregiões homogêneas, na análise fatorial em 25 indicadores. Pernambuco,. 1950 a 1980.

7.10 Valores do Fator 3 (mecanização com ênfase na cana-de-açúcar), segundo microrregiões homogêneas, na análise fatorial em 25 indicadores. Pernambuco, 1950 a 1980

7.11 Variação $(\Delta)$ dos valores do Fator 3 (mecanização com ênfase na cana-deaçúcar), segundo microrregiões homogêneas, na análise fatorial em 25 indicadores. Pernambuco, 1950 a 1980.

7.12 Valores do Fator 4 ("assalariamento e relações de trabalho nãomodernizadas e subutilização do recurso terra"), segundo microrregiões homogêneas, na análise fatorial em 25 indicadores. Pemambuco, 1950 a 1980... 7.13 Variação $(\Delta)$ dos valores do Fator 4 ("assalariamento e relações de trabalho não-modernizadas e subutilização do recurso terra"), segundo microrregiões homogêneas, na análise fatorial em 25 indicadores. Pernambuco, 1950 a 1980

7.14 Raizes características da matriz de correlações simples (32 x 32) para as microrregiões homogêneas e mesorregiões* do Estado de Pernambuco, $1995 / 1996$.

7.15 Percentagem da variância explicada por cada fator antes e após a rotação ortogonal.

7.16 Coeficientes de correlação (cargas fatoriais), comunalidades e percentagem da variância explicada por cada fator após a rotação pelo método Varimax, na extração de três fatores em 32 indicadores. Microrregiões Homogêneas e Mesorregiões* do Estado de Pernambuco, 1995/96.

7.17 Percentagem de grupos de variáveis segundo o grau de correlação entre cada fator e a variável

7.18 Valores dos fatores, segundo microrregiões homogêneas e mesorregiões, na análise fatorial em 32 indicadores. Pemambuco, 1995/96. 


\title{
MODERNIZAÇÃO AGRÍCOLA EM PERNAMBUCO, 1950-1996
}

\author{
Autor: WILUAM SABBAG \\ Orientador: Prof. Dr. GERALDO SANT'ANA DE CAMARGO BARROS
}

\section{RESUMO}

Este trabalho analisa o processo de modemização agrícola nas microrregiões no período de 1950 a 1996. Os principais objetivos foram os de identificar os padrões ou dimensões características do processo, os níveis de modemização, segundo as unidades geográficas, e suas tendências. Foram efetuadas análises estáticas para os anos de 1960, 1980 e 1995/1996 e uma análise dinâmica para o período 1950/1960/1970/1980.

Os dados estatísticos oriundos dos Censos do IBGE foram interpretados a partir da análise fatorial, pelo método dos componentes principais, que permitiu resumir grande quantidade de indicadores de modernização, representando o fenômeno através de pequeno número de variáveis sintéticas ou fatores estimados. Forneceu, também, os escores fatoriais ou índices, os quais possibilitaram identificar os graus de modernização, segundo microrregiões, para cada fator ou estrutura específica de representação do processo, nos vários cortes temporais.

Em Pernambuco, ainda predomina uma agricultura de baixo padrão tecnológico e a distribuição espacial da modemização continua bastante desigual. Além disso, o conjunto de microrregiões mais modemizadas manteve-se relativamente estável desde os anos 1950. Em conseqüência, as microrregiões que apresentaram níveis mais 
altos de modernização são as que evidenciaram tendência mais acentuada de incremento do processo, implicando um aumento da diferenciação: Mata Seca, Mata Úmida, Recife e Sertão Pernambucano do São Francisco.

A tendência de desenvolvimento de um padrão mais elementar de modernização, através da utilização da tração animal, foi identificada para o periodo 1950/80, para microrregiões do Agreste e do Sertão. Em oposto, na Zona da Mata, existiu tendência de afastamento em relação a esse padrão, em favor de um padrão de modernização mais consistente.

Resumidamente, a investigação dos dados resultantes da análise fatorial dinâmica evidenciou a existência de duas tendências de modernização - convencional (mecanização e insumos químico-biológicos) e a elementar (principalmente a tração animal) -, resultando em três grupamentos geográficos: microrregiões com predomínio de tendência de modernização convencional: as da zona canavieira e Agreste Setentrional; microrregiões com tendência equilibrada entre os dois padrões: São Francisco e Salgueiro, refletindo forte dualidade tecnológica; microrregiões com tendência predominante de desenvolvimento de padrão elementar de tecnificação: microrregiões do Agreste - excetuando-se o Agreste Setentrional - e microrregiões do Sertão.

A análise dinâmica também revelou uma estrutura relativa ao desenvolvimento da pecuária melhorada que, grosso modo, continuaria localizada nas mesmas microrregiões, apesar de decorridos 30 anos: as microrregiões da zona canavieira e as do Agreste, e no Sertão, apenas o Vale do Pajeú.

De outra parte, considerando-se os dados do Censo de 1995/96, os resultados da análise fatorial estática evidenciaram níveis de modernização mais elevados para as microrregiões homogêneas da zona canavieira. Revelaram, ainda, modernização em partes das antigas microrregiões Agreste Setentrional e Agreste Meridional, respectivamente MRH Médio Capibaribe e MRH Brejo Pernambucano. Através da identificação de uma segunda estrutura na qual a mecanização e assistência técnica se associaram à irrigação, constatou-se elevados escores fatoriais para o Sertão Pernambucano do São Francisco, Mata Seca e Recife. 
Em síntese, houve tendência generalizada de modernização em todas as microrregiões, porém com mais intensidade nas mais modemizadas. Como resultado, tanto nos anos 1980 quanto nos anos 1990, as principais microrregiões com indícios de modemização mais consistente continuaram a ser as da Zona da Mata, em função de sua principal atividade a cana-de-açúcar, e o Sertão do São Francisco, dado o dinamismo propiciado pelo crescente uso de sistemas irrigados. 


\title{
THE MODERNIZATION OF AGRICULTURE IN PERNAMBUCO STATE, 1950-1996
}

\author{
Author: WILIAM SABBAG \\ Adviser: Prof. Dr. GERALDO SANT'ANA DE CAMARGO BARROS
}

\section{SUMMARY}

This study analyses the process of agricultural modernization in the Homogeneous Microregions (HMR) of Pernambuco between 1950 and 1996. The main objectives have been to identify the characteristic standards or dimensions of the process, the levels of modernization, according to the geographical units, and their tendencies. Static analyses were carried out for the years 1960, 1980 and 1995/1996 and a dynamic analysis for the period 1950/1960/1970/1980.

The statistical data from the I.B.G.E. (The Brazilian Institute for Geography and Statistic) Census were interpreted using factor analytical technique, according to the method of the principal components, that allowed the summary of a large number of indicators of modernization, representing the phenomenon through a small number of synthetic variables or estimated factors. It also supplied the factor scores or indexes, which made the identification of the levels of modernization possible, according to the Microregions, for each factor or structure of representation of the process, at specific points in time.

In Pernambuco, low technology agriculture still predominates and the distribution of modernization continues to be very unequal. In addition to this, the group 
of more modemized Microregions has remained relatively stable since the 1950s. As a result, the Microregions that have revealed the highest levels of modernization are those which evidenced accentuated tendency of increment in the process, implying an increase of the differentiation: Mata Seca, Mata Úmida, Recife e Sertão Pernambucano do São Francisco.

The tendency to develop a more basic modernization model, through the use of animal traction, was identified for the period 1950-80, in Microregions of the Macroregions Agreste and Sertão. By contrast, in the Macroregion Zona da Mata, there has been the tendency to move away from this model, in favour of a more consistent technological modemization.

In short, the investigation of the data from the factor dynamic analysis revealed the existence of two tendencies of modernization - conventional or advanced technology (mechanization and chemical / biological inputs) and elementary or rudimentary technology (mainly animal traction and use of the plow) -, resulting in three geographical groups: Microregions with a predominant tendency towards the development conventional modernization: those of the sugar-cane zone and Agreste Setentrional; Microregions with tendencies balanced between the two patterns: São Francisco and Salgueiro, reflecting strong technological duality; Microregions with a predominant tendency towards the development of the elementary standard modernization: Microregions of the Sertão and Agreste - with the exception of the HMRs Sertão Pernambucano do São Francisco e Agreste Setentrional.

The dynamic analysis (1950-80) also revealed a structure relative to the development of improved cattle-farming which, in general terms, continued to be located in the same Microregions, even after 30 years: the Microregions of the sugarcane belt and those of the Agreste, and in the Sertão, just the HMR Vale do Pajeú.

On the other side, taking into account the data from the 1995/96 Census, the results of the static analysis displayed higher levels of modemization for the Homogeneous Microregions of the sugar-cane belt. They also revealed modernization in parts of the old Microregions Agreste Setentrional and Meridional Agreste, respectively, HMR Médio Capibaribe and HMR Brejo Pernambucano. Through the identification of a 
second structure in which the mechanization and technical assistance were linked to irrigation, high factor scores were recorded for the Sertão Pemambucano do São Francisco, Mata Seca and Recife.

To summarize, there has been a generalized modernization tendency in all the Microregions, however, with greater intensity in those most modernized. As a result, both in the 80s and in the 90s, the main Microregions with the most consistent factor scores of modernization continued to be those of the Macroregion Zona da Mata, due to the predominance of sugar-cane production, and the Microregion Sertão Pernambucano do São Francisco, given the dynamism generated by the growing use of irrigation systems. 


\section{INTRODUÇÃO}

Este estudo pretende analisar o processo de modemização da agricultura em Pernambuco, através de suas microrregiões, no periodo 1950/1996.

A incorporação e a difusão do progresso técnico na agricultura pernambucana têm sido bastante heterogêneas, no sentido de que a utilização de moderna tecnologia vem-se dando de forma diferenciada e parcial. Nesse sentido, a modernização tecnológica tem-se revelado seletiva, ao verificar-se mais fortemente em lavouras de produtos de exportação e alguns produtos nobres da hortifruticultura. Em acréscimo, a adoção de novas tecnologias é parcial, ao localizar-se em apenas algumas etapas do ciclo produtivo. A diversidade tecnológica entre os agricultores, mesmo considerando-se as lavouras modernas, a exemplo da cana-de-açúcar, é bastante grande.

Em Pernambuco, esse caráter seletivo da modernização expressou-se espacialmente, na formação de bolsões, a exemplo da agricultura irrigada do submédio São Francisco e das microáreas de brejo de altutude, na mesorregião Agreste, especializadas na hortifruticultura e floricultura.

Em linhas gerais, o processo de modernização tem ocorrido, de um lado, através da introdução ou expansão de novas culturas, do subsetor hortifruticultura, cujas etapas de produção de seus ciclos produtivos já pressupõem uma base técnica mais avançada; de outro lado, pela supressão ou afastamento das lavouras tradicionais, principalmente os alimentos básicos, que passaram a ocupar preferencialmente as áreas menos férteis. 
Considerando-se o espaço territorial do estado, há um reordenamento tanto da composição da produção quanto da distribuição espacial das culturas; ou seja, alteraram-se a pauta de produtos e o padrão geográfico de produção de algumas lavouras. Entretanto, do lado da distribuição espacial dos alimentos básicos e da canade-açúcar, as modificações são menos agudas. Ou seja, o padrão geográfico dessas culturas, em termos de mesorregião, pouco se alterou. No entanto, há que se destacar que a partir dos anos 70 inicia-se um movimento expansivo da cana-de-açúcar, principalmente na Mata Seca, e em áreas limítrofes da mesorregião Agreste, ocupando áreas antes reservadas a pastagens e ao plantio de alimentos.

Especialmente a microrregião Mata Seca vai apresentar mais intensamente a incorporação de progresso técnico, sobretudo a mecanização, cuja adoção foi favorecida pelo relevo, ao contrário da maior parte da Mata Úmida.

Observando-se os três grandes espaços mesorregionais do estado, há a ocorrência de um processo de especialização entre essas macro unidades geográficas. No Agreste, processou-se um movimento duplo, caracterizado pela atração e fuga de produtos da hortifruticultura. Enquanto cresce e se expande uma ampla variedade de legumes, verduras e condimentos, outras lavouras como a cebola e o tomate destinados às agroindústrias, deslocam-se para o Sertão. Principalmente nessa mesorregião, expande-se uma ampla sorte de culturas irrigadas. Ou seja, a partir dos anos 1950 ocorre um processo de redefinição do uso da terra, acarretando em espaços bastante circunscritos a diversificação agrícola.

Apesar da importância econômica das novas culturas, em termos do aumento dos índices intersetoriais de ligações para trás, ou seja, como demandante de insumos modernos, sua expressão em termos comparativos com os tradicionais alimentos básicos, juntamente com a cana-de-açúcar, ainda é pequena. Cabe ainda a esses dois subsetores a maior fatia de participação no valor bruto da produção vegetal do estado.

Em resumo, a modemização vai expressar-se tanto pela tecnificação do processo produtivo das culturas já existentes, quanto através da substituição de culturas tradicionais por outras de maior valor comercial, cujos sistemas de produção 
incorporados pelo agricultor, já são bastante tecnificados, principalmente no que se refere à utilização de inovações biológicas e fisico-químicas, mais acessiveis ao pequeno produtor, ao contrário da mecanização (trator) que dependeria de uma escala minima de produção.

Esse processo de modernização foi viabilizado por instrumentos de politicas governamentais, notadamente o crédito, além da assistência técnica e extensão, e da pesquisa agrícola. Programas especiais, principalmente voltados à irrigação, foram também responsáveis pela modernização e redefinição do uso das melhores terras ao longo da margem do trecho submédio do São Francisco.

\subsection{Objetivos}

O objetivo geral do estudo é o de analisar os padrões e a dinâmica do processo de modernização agrícola, no Estado de Pernambuco, em suas 12 microrregiões, entre 1950 e 1996, e em subperíodos: 1950/60, 1960/70, 1970/80, e efetuar uma caracterização microrregional da modernização para 1995/96.

Os objetivos especificos são:

a) Extrair as principais dimensões subjacentes ao processo de modernização (fatores ou variáveis sintéticas), a partir de um conjunto de indicadores selecionados;

b) Estabelecer os niveis de modernização nas diferentes unidades geográficas assinaladas, revelando a distribuição espacial do processo;

c) Extrair os padrões de modernização a partir da estratificação microrregional em niveis diferenciadores do processo para cada dimensão ou fator; 
d) Analisar a evolução da modernização com base no comportamento dos escores para cada microrregião, tomados para os períodos, segundo as dimensões características do processo.

\subsection{Hipóteses}

As hipóteses delineadas a seguir foram extraidas a partir de evidências apontadas pela literatura e nortearão o sentido da investigação, através da qual os dados, uma vez analisados, servirão para testá-las.

A modernização da agricultura pernambucana estar-se-ia propagando de forma bastante heterogênea, ao incidir-se mais incisivamente em apenas algumas lavouras; revelar-se-ia também parcial, ao verificar-se apenas em algumas etapas do ciclo produtivo e, predominantemente, em determinadas categorias de produtores.

Esse processo de modernização teve seu início nos anos 1950, e poderiam ser creditadas como causas, a crescente urbanização, que alargou e sofisticou os mercados consumidores, e o conseqüente decréscimo de população rural. A esse processo foram-se somando os instrumentos de políticas governamentais, em especial o crédito rural, e seus complementos: a pesquisa agropecuária, a assistência técnica e extensão rural. Programas específicos voltados ao fomento da irrigação também teriam concorrido para a modemização. As próprias condições edafo-climáticas, características de cada mesorregião (Mata, Agreste e Sertão) ou de microáreas, teriam contribuído para a incorporação de novas tecnologias, ou mesmo tomando-as inviáveis. Contemporaneamente, a desregulamentação do setor sucroalcooleiro estaria promovendo sua modernização forçada.

Todo esse conjunto de elementos propulsores da modemização haveria incidido de forma desigual sobre a agricultura, implicando uma evolução diferenciada, em termos da incorporação e difusão do progresso técnico. Esse caráter desigual de estímulos ao setor teria consubstanciado a existência de diferentes dimensões estruturais (fatores). Goograficamente, essa desigualdade ter-se-ia revelado em niveis e padrões distintos de modemização. 
Tem-se como hipótese que a modernização haveria sido parcial e heterogênea. Isto posto, esperam-se padrões e niveis de modernização bastante distintos. Supõe-se que a modernização tenha sido seletiva, concentrada espacialmente, em meio a um contexto de generalizado predomínio de baixo nível tecnológico.

Fenômenos como a urbanização e o seu contraponto, a desruralização em termos de perda de população rural, e políticas de governo direcionadas ao setor agrícola, teriam contribuido na conformação de niveis e padrões de modernização diferenciados, alterando a composição e distribuição da produção em áreas especificas.

Um grande número de variáveis indicadoras do processo de modernização, que serão analisadas individualmente e, em conjunto, através da análise fatorial, servirão para identificar as dimensões subjacentes ao processo e os niveis e padrões de modernização, caracterizando as desigualdades microrregionais, em termos de espaços geográficos diferenciados tecnologicamente.

\subsection{Organização do trabalho}

Esta Tese compõe-se da seguinte estrutura: após o capítulo introdutório apresentado anteriormente, discorre-se sobre o conceito de modernização e as contribuições teóricas de alguns modelos acerca do processo diferenciado de transformação tecnológica e o desenvolvimento em economias dualistas. No próximo item, faz-se uma caracterização do processo de modemização no estado e em suas mesorregiões. Na seção seguinte, essa caracterização é reforçada, ao mesmo tempo em que se fornecem elementos complementares interpretativos à apresentação de conclusões e dados sobre Pernambuco, - que aqui são também reinterpretados -, referentes aos estudos empíricos sobre modernização através da análise fatorial. A exposição de elementos da metodologia vem na seqüência. Os resultados preliminares sobre a modernização agrícola, obtidos através das análises fatoriais estáticas para 1960 e 1980, visando ao teste dos indicadores, e as conclusões decorrentes dos resultados dessa análise fatorial, compõem, juntamente com os capítulos anteriores, o primeiro segmento referente à parte textual desta Tese. Seguem-se os resultados da análise fatorial dinâmica 
do periodo 1950/80, revelando as tendências do processo, e na seqüência da investigação, os da análise fatorial estática dos dados de 1995/96, que forneceram uma caracterização microrregional mais recente da modernização no estado. Completando o trabalho, expõem-se as principais conclusões acerca dos resultados das análises fatoriais. Ao final, listam-se as referências bibliográficas. 


\section{MODERNIZAÇÃO DA AGRICULTURA}

\subsection{O Conceito de modernização}

O termo modemização agrícola vem sendo usualmente empregado enquanto processo de mudança na base técnica de produção - em termos de substituição e incorporação de progresso técnico - e nas relações sociais de produção, especialmente pelo crescimento do trabalho assalariado.

Entre os clássicos, Marx foi um dos que verificou e analisou o surgimento desse processo, em países como a Inglaterra e a Alemanha, no decorrer do século XIX. Na célebre obra "O Capital", no capítulo "A maquinaria e a indústria moderna", dedicou uma seção ao tema que intitulou "Indústria moderna e agricultura". Tratou a modemização enquanto ... "revolução realizada pela indústria moderna na agricultura e nas relações sociais de seus agentes de produção”. Portanto, toma como origem do processo o setor urbano-industrial. Enfatizou o emprego crescente de máquinas, que fazia decrescer a população rural, dando-lhe uma finalidade estratégica: prover de mão-de-obra a indústria emergente.

Segundo Marx (1971, p.571), “a indústria moderna atua na agricultura mais revolucionariamente que em qualquer outro setor, ao destruir o baluarte da velha sociedade, o camponês, substituindo pelo trabalho assalariado. As necessidades de transformação social e a oposição de classes no campo são assim equiparadas às da cidade. Os métodos rotineiros e irracionais da agricultura são substituídos pela aplicação consciente, tecnológica da ciência...”. 
Denotando a busca pelo aumento da produtividade do trabalho e da terra e suas conseqüências, observa que ..."na agricultura moderna, como na indústria urbana, o aumento da força produtiva e a maior mobilização do trabalho obtêm-se com a devastação e a ruína fisica da força de trabalho. E todo o progresso da agricultura capitalista significa progresso na arte de despojar não só o trabalhador mas, também, o solo; e todo aumento da fertilidade da terra num tempo dado significa esgotamento mais rápido das fontes duradouras dessa fertilidade. Quanto mais se apóia na indústria moderna o desenvolvimento de um país, como é o caso dos Estados Unidos, mais rápido é esse processo de destruição. A produção capitalista, portanto, só desenvolve a técnica e a combinação do processo social de produção, exaurindo as fontes originais de toda a riqueza: a terra e o trabalhador" (Marx, 1971, p.579).

No capítulo "A chamada acumulação primitiva", dedica outra seção à agricultura: "Repercussões da revolução agrícola na indústria; formação do mercado interno para o capital industrial". O que hoje rotineiramente a literatura corrente denomina modernização, era analisada por Marx como uma revolução agrícola que expropriava e expulsava a população rural. Entretanto, “a terra continuava a proporcionar a mesma quantidade de produção ou maior, a despeito do escasseamento de camponeses independentes, pois a revolução no regime de propriedade territorial corria paralela com a melhoria dos métodos de cultura, com maior cooperação, concentração dos meios de produção etc., e porque os assalariados tinham que trabalhar mais intensivamente dispondo de uma área cada vez menor..." (Marx, 1971, p.863). Ou seja, o aumento da produtividade da terra e do trabalho intensificava a exploração, liberando força de trabalho.

Esse processo vai-se manifestando, paulatinamente, numa crescente especialização e monetização na agricultura e em sua relação setorial com a indústria. A principal implicação dessa nova articulação foi a formação de um mercado interno para o capital industrial... "parte dos habitantes rurais se torna disponivel e se desvincula dos meios de subsistência com que se abastecia. Esses meios se transformam então em elemento material do capital variável. Os camponeses expulsos têm de comprar o valor desses meios, sob a forma de salário, a seu novo senhor o capitalista industrial... Na 
realidade, a família camponesa produzia e elaborava os meios de subsistência e matérias-primas que eram, na sua maior parte, consumidos por ela mesma. Esses meios de subsistência e matérias-primas transformam-se agora em mercadorias..." (Marx, 1971, p.865).

Os elementos da conceituação básica de modemização agrícola incorporados pelos autores que analisam esse processo mantêm-se em sua essência os mesmos: mudanças na base técnica e nas relações de produção.

Tomando-se um dos trabalhos pioneiros de análise fatorial sobre modernização agrícola (Mesquita et al., 1977, p.4), esse conceito é visto como hierarquicamente situado em nível decrescente aos conceitos de desenvolvimento rural e desenvolvimento agrário, mas em sintese trata a modemização enquanto incorporação de progresso técnico visando ao aumento da produtividade. Segundo os autores, "em termos conceituais, desenvolvimento rural tem caráter abrangente, englobando não só o desenvolvimento agrário mas também as condições de bem-estar da população rural. $O$ desenvolvimento agrário incorpora a modernização agrária e também uma institucionalização ligada a aspectos infra-estruturais de apoio creditício e de pesquisa e extensão rural; ele incluiria, então, o desenvolvimento da atividade agrária e seus aspectos de vinculação a um contexto econômico-regional. Já a modemização agrária corresponde a uma melhoria da agricultura pela adoção de técnicas modernas, com o objetivo de alcançar maior produtividade e rendimento da terra e do trabalho".

Dessa forma, os autores apresentam "os conceitos de desenvolvimento rural, desenvolvimento agrário e modemização agrána, em niveis decrescentes de abrangência, havendo, portanto, grupos diferentes de indicadores para esses conceitos, possibilitando, assim, efetuar análises em separado dessas linhas de abordagem ao estudo da agricultura".

Mesquita et al. (1977, p.4) chamam a atenção para a relatividade do conceito de modemização “... já que pode ser representada, em diferentes contextos, por diferentes indicadores ligados a uma grande variedade de técnicas e de procedimentos adotados nas atividades agrárias". 
Eisenstadt (1966), citado por Cunha (1978, p.3-4), revela que a modemização em um contexto histórico, “... é o processo de mudança através de tipos de sistemas sociais, econômicos e políticos que se têm desenvolvido na Europa Ocidental e América do Norte, do século dezessete ao dezenove, e têm-se espalhado para os demais paises da Europa e, nos séculos dezenove e vinte, para a América do Sul, Ásia e o continente africano". E acrescenta que, "similarmente, a modernização agrícola pode ser definida como o processo de mudança através do qual a agricultura "tradicional" adquire características de sistemas agricolas de paises mais desenvolvidos". Para Cunha (1978, p.4), "esta idéia é mais bem expressada por Marx, que escreveu no prefácio de "O Capital", que... "Os países que são mais desenvolvidos... somente mostram, para os menos desenvolvidos, a imagem do seu próprio futuro".

Hoffmann \& Kassouf (1989, p.275) tomam a modernização da agricultura ... “essencialmente como progresso tecnológico, que permite aumentar a produtividade do trabalho e da terra; mas são consideradas também as relações sociais de produção".

Também seguindo esse raciocínio, Zanchet (1990, p.54) afirma que “o desenvolvimento capitalista na agricultura brasileira está associado a mudanças na base técnica e nas relações de produção. O processo que aprofunda e consolida tais mudanças tem sido denominado genericamente de "modemização agrícola". ... "a modernização agrícola representa o processo de mudança tecnológica, que leva ao aumento da produtividade do trabalho e da terra, abrangendo inclusive as relações sociais de produção".

Troncoso Leone (1988, p.29-30), baseando-se em Kageyama (1987), apresenta a modernização agricola como uma transformação temporal iniciada desde os primórdios da civilização. Em sua fase inicial, a agricultura revelava-se auto-suficiente, tanto em relação ao processo produtivo, quanto ao provimento dos gêneros destinados à reprodução da força de trabalho. Paulatinamente, foi havendo um processo de especialização, de monetarização e mercantilização da atividade. Intensifica-se a divisão social do trabalho e aumentam as relações intersetoriais agricultura-indústria. Segundo 
Kautsky, trata-se do processo de industrialização do campo, que fora iniciado a partir da Revolução Industrial.

No decorrer do tempo, diferenciadamente entre paises, regiões, classes de agricultores, e culturas, esse processo tomou curso. $\mathbf{O}$ caráter desigual de propagação do progresso técnico resultou, principalmente nos paises em desenvolvimento, em dualismo tecnológico, dada a coexistência de um setor agricola moderno e outro tradicional. Neste contexto, ocorreria uma multiplicidade de situações: coexistência de niveis e padrões diversos de modernização, mesmo dentro do mesmo espaço microrregional.

Para Andrade (1989, p.81), o conceito de modemização utilizado por ele não se reduz apenas às modificações ocorridas na base técnica de produção, que consistiria na passagem de uma agricultura natural para uma que utiliza insumos fabricados industrialmente. Incorporando a teoria manista, e citando Silva (1981, p.24), reconhece o progresso técnico como... "progresso das técnicas capitalistas de produção, ou seja, como um dos elementos da dominação do capital sobre o trabalho". Segundo Andrade, ... "o processo de modernização da agricultura deve ser analisado dentro do contexto da aplicação do progresso técnico na sociedade capitalista, que visa a elevação geral da produtividade da força de trabalho e sua subordinação ao capital".

Guedes (1992, p.39-40), seguindo argumentação semelhante, desta feita apoiando-se em Graziano Neto (1986), afirma que "modernização da agricultura não consiste apenas de modificações ocorridas na base técnica de produção; na substituição de técnicas agrícolas tradicionalmente utilizadas por técnicas modernas". ... “a modernização significa também que, ao mesmo tempo em que vai ocorrendo progresso técnico, vai-se modificando a organização da produção... a composição e a utilização do trabalho modificam-se, intensificando-se o uso do "bóia-fria" ou trabalhador volante; a forma de pagamento da mão-de-obra é cada vez mais o salário; os pequenos produtores, sejam proprietários, parceiros ou posseiros, vão sendo expropriados, dando lugar em certas regiões, à organização da produção em moldes empresariais”.

Figueiredo (1996, p.5) enfatiza também a modemização como transformações na base técnica e nas relações sociais de produção. $O$ processo de 
modernização resultaria crescentemente numa produção apoiada ... "no uso intensivo de insumos modernos - máquinas e implementos, fertilizantes químicos e corretivos, e controle químico de pragas e doenças - que resulta em alta produtividade do trabalho e da terra... O avanço técnico no campo é acompanhado de mudanças nas relações de trabalho, desaparecendo formas tradicionais de parceria, que são substituídas pelo assalariamento".

\subsection{Modelos teóricos sobre o desenvolvimento da agricultura}

Após ter evidenciado o conceito de modernização, trata-se agora de explorar o conteúdo de alguns modelos ${ }^{1}$, em uma abordagem resumida, e, portanto, sem a pretensão de exaurir o tema. O objetivo é o de evidenciar algumas contribuições, sem a preocupação de uma exposição formal dos modelos, tendo-se como fio condutor a questão da transformação tecnológica da agricultura.

Caberia, de início, caracterizar a diferenciação tecnológica existente nos países em desenvolvimento. Em seu aspecto básico, manifesta-se em decorrência de um processo de intensidade variada, cuja propagação revela-se lenta e desigual no âmbito geográfico, e em nível de produtos e das unidades produtivas. Essa desigualdade pode também ser observada tanto dentro da unidade quanto entre unidades produtivas. Quer dizer, as faces da desigualdade tecnológica revelam-se múltiplas.

Essa desigualdade de propagação do progresso tecnológico em algumas situações terá reforçado diferenciações preexistentes, e em outras, conformado padrões tecnológicos distintos, cada qual englobando níveis diferenciados de modernização. Em função disso, pode-se constatar a existência de extremos tecnológicos representativos

\footnotetext{
${ }^{1}$ Uma conceituação do signifícado dos modelos é apresentada por Araújo \& Schuh (1997, p.17), que os concebem como sendo ... "a especificação de relações entre fatores econômicos e sociais. Esses fatores devem ser representados por variáveis críticas do mundo real. As relaçöes podem ser estabelecidas em palavras e em forma geométrica ou matemática Normalmente, as variáveis explícitas de um modelo são: (a) dependentes e (b) independenter As relações sugeridas pelo modelo devem ser indicadas e antexipadas sempre que possivel. Ademais, para que os modelos tenham maior validade cientifica, as variáveis devem ser estatisticamente mensurúreis para permitî o teste empínico do modelo".
} 
dessa diferenciação: os estabelecimentos que empregam somente técnicas modernas e os excluidos do processo, os de "agricultura de enxada". Um meio termo, representativo da ambivalência tecnológica inserida em uma mesma unidade produtiva, caberia aos estabelecimentos conduzidos por agricultores que fizeram adaptações na base técnica tradicional, introduzindo complementar e parcialmente tecnologias modernas. A coexistência de utilização de técnicas modernas e tradicionais intra ou entre explorações e regiões, é referida enquanto dualismo tecnológico, que poderia ser peculiar às sociedades em processo de transição. ${ }^{2}$

De acordo com Fei \& Ranis (1975), “a característica central do dualismo é a coexistência de um grande setor agrícola com um ativo e dinâmico setor industrial. A indústria utiliza capital e ambos os setores sofrem mudança tecnológica contínua, à medida que interagem durante o processo de crescimento...". Através desse modelo teórico ... "defendem a idéia de que o desenvolvimento deve seguir pela transição, primeiro, do agrarianismo ${ }^{3}$ para o dualismo e, depois, do dualismo para a maturidade...".

Por outro lado, Myint (1964), citado por Ruttan (1975, p.165), enfatiza a importância do mercado de capital, como base para o dualismo de enclave ${ }^{4}$. A hipótese é a de que o custo do capital é mais baixo para o setor moderno induzindo, em conseqüência, a adoção de técnicas intensivas que levam à baixa demanda por mão-deobra. Ao contrário, para o setor tradicional, o preço mais elevado do capital inviabilizaria investimentos.

\footnotetext{
2 Rostow (1964), citado por Araújo \& Schuh (1997, p.34), identificou cinco etapas para o processo de desenvolvimento econômico: sociedade tradicional, pré-condição para o arranco, arranco, marcha para mahuridade e consumo de massa. A etapa "pré-condição para o arranco" refere-se às ... "sociedades em processo de transição, à medida que o avanço tecnológico se converte em "hovas funções de produçâo tanto na agricultura quanto na indústria" ... "Em muitos casos, escas transformaçōes ocorrem em ritmo muito lento. Ademais, é muito comum a coexistência de um setor moderno, relativamente pequeno, e de outro, maior, tipicamente tradicional, o que dá origem ao dualismo tecnológico".

${ }^{3}$ Fei \& Ranis (1975) conceituam o agranianismo como sendo um sistema econômico onde há a preponderância das atividades agricolas. A economia agrána é exsencialmente estacionána. As atividades não-agrícolas são caracterizadas por um modesto uso de capital.

${ }^{4}$ Ruttan (1975, p.162-165) situa o "dualismo de enclave" e o "dualismo sociológico" como as duas variações do dualismo estático, através do qual enfatiza-se a interąão limitada entre os setores tradicional e moderno. Citando Singer (1950), afirma que o dualismo de enclave...reflete expressivamente os esforços de um número de teóricos sobre o comércio para explicar "o espetáculo de ... um setor de alta produtividade produraindo para exportação coexistente com um setor de baixa produção para o mercado doméstico".
} 
Essa ambivalência tecnológica e, em outros casos, a ausência de incorporação de técnicas modemas, estão intrínsecas ao modelo teórico proposto por Mellor (1967), citado por Araújo \& Schuh (1997, p.39), que pode ser representado por uma função de produção relacionando a produção total de uma agricultura tradicional a uma série de fatores ou insumos. Alguns fatores são utilizados apenas na função de produção típica tradicional; são eles os insumos tradicionais. Outros fatores, os insumos modernos, são utilizados em conjunto com os tradicionais na agricultura moderna. Desse modelo, deriva-se a hipótese de que as mudanças tecnológicas podem complementar os insumos tradicionais e torná-los mais eficientes.

Para Jorgenson (1975, p.137), “é amplamente reconhecido que, nas condições contemporâneas, a maioria dos sistemas econômicos retrógrados tem relações importantes com economias avançadas, através do comércio internacional ou através do estabelecimento de um "enclave" moderno em um contexto social e economicamente atrasado: também as relações existentes fazem crescer o dualismo econômico e social, isto é, um dado sistema consiste de duas partes componentes - um setor avançado ou moderno e um setor atrasado ou tradicional".

Apreendendo-se o progresso técnico sob o ângulo da unidade produtiva, tem-se a contribuição de Fei \& Ranis $(1975$, p.122), para os quais “o proprietário dualista, em sua condição de agricultor, tem interesse crescente na inovação agrícola à medida que as potencialidades da industrialização tornam-se aparentes para ele ... o aumento da produtividade agrícola é considerado elemento dos mais importantes para provocar o equilibrio intersetorial do sistema dualista. Esse fenômeno pode ser chamado de ajustamento tecnológico positivo".

Hayami \& Ruttan (1971), citado por Paiva (1975, p.119), ... “mostram que o modelo que esteve em voga por mais tempo, conhecido por "modelo de difusão"s, procura explicar a modernização da agnicultura pela simples disseminação de técnicas que implicam em maiores produtividades dos fatores terra, mão-de-obra e capital e que

\footnotetext{
5 Paiva (1975, p.124) considera “... "adoção" e "difusāo" de técnicas modemas como fases distintas do processo de modemização. A adoção é um fenômeno de características microeconômicas, basicamente da alçada direta dos agricultores... ao contrário, a difusão tem caracteristicas macroeconômicas, uma vez que a modernização feita por um grande número de agricultores depende de outros elementos, inclusive do comportamento da economia em geral".
} 
trazem, assim, maiores retornos financeiros aos agricultores". Segundo Paiva (1975, p.120), duas são as limitações desse modelo: sua utilização não implicou em modernização da agricultura em paises em desenvolvimento, apesar da assistência técnica e financeira oferecidas; não explicou a ocorrência do dualismo, pois se as técnicas modernas são vantajosas numa região, nada impediria que outros agricultores as adotassem.

Araújo \& Schuh (1997, p.39), além do modelo de difusão, citam seis outros modelos teóricos sobre o desenvolvimento da agricultura: 1. Modelo de exploração dos recursos produtivos; 2. Modelo de conservação dos recursos; 3. Modelo de localização, baseado na obra de Von Thünen; 4. Modelo de insumos modernos de Schultz; 5. Modelo de inovações induzidas de Hayami \& Ruttan; 6. Modelo de Janvry.

Modelos desenvolvidos por Schultz contribuiram para o desvendamento teórico dessas questões relacionadas ao processo de transformação desigual da agricultura, a exemplo do de 1951, que tem como hipótese o impacto industrial (Ruttan, 1975, p.157). Segundo Paiva (1975, p.120), Schultz (1953) relaciona a melhoria da agricultura ao desenvolvimento de centros urbano-industriais. Áreas que lhe são próximas têm mercados de fatores mais eficientes, acarretando a adoção de processos produtivos com melhores resultados na produção. Outra contribuição de Schultz (1965), foi a de mostrar que as possibilidades de produção de uma agricultura tradicional já se encontram esgotadas "... "face aos recursos e conhecimentos de arte" de seus agricultores; que não é possivel nessa agricultura aumentar a produção com a simples realocação de fatores; e que a criação de "correntes adicionais de renda" depende de se terem "fontes" modernas de renda (insumos materiais e novos conhecimentos) a preços baixos a fim de que possam gerar não apenas acréscimos de produtividade como de renda".

A partir das idéias de Schultz, foram elaborados com mais detalhes o conceito de insumos modernos de alta rentabilidade. Segundo Hayami \& Ruttan (1971), citados por Paiva (1975), esses insumos surgem como respostas às restrições de disponibilidade de recursos e às condições econômicas do país. $\mathrm{O}$ modelo desses autores, embora explique a criação de novas técnicas, é de pouca utilidade para países 
que já contam com estoques consideráveis de técnicas modernas. O motivo pelo qual a difusão tecnológica não se processa massivamente, apesar da vontade dos agricultores e dos esforços de todo aparato da assistência técnica, não encontraria explicação nesse modelo (Paiva, 1975, p. 121).

No modelo de Hayami \& Ruttan (1971), o setor público é induzido a gerar inovações técnicas e institucionais. Parte-se de um estoque de conhecimentos, que define a curva de possibilidades de inovação. As mudanças na escassez relativa do fator acarretariam alterações nos preços relativos dos fatores, conduzindo, dentro da curva de possibilidades de inovação, a identificação de tecnologias minimizadoras de custos. As novas oportunidades tecnológicas poderiam induzir a mudanças institucionais que facilitariam aos agentes econômicos a usufruir seus beneficios.

Janvry (1978) também desenvolve um modelo no qual o setor público tem papel ativo no processo de transformação tecnológica. A geração de inovações oriundas desse setor está inserida em um processo dinâmico e interativo englobando a demanda e a oferta. Pressupõe-se que cada grupo social possa exercer pressões (lobby) na busca de seus interesses. $O$ sucesso de um pode significar perda para outro, já que a adoção tecnológica derivada de mecanismos institucionais facilitadores, em atendimento às demandas específicas, não irá beneficiar a todos os grupos simultaneamente.

Paiva (1975, p.119), em seu trabalho sobre modemização e dualismo tecnológico na agricultura, considera a hipótese de que ... "os agricultores tradicionais não se modemizam porque obtêm com suas técnicas retornos financeiros maiores do que poderiam obter com a modernização".

A adição de outros elementos, ausentes nos modelos anteriores, seria capaz, segundo Paiva (1975, p.122), de fornecer uma explicação mais completa dos problemas de modernização nos países em desenvolvimento. Esse autor constata a existência de um mecanismo de autocontrole, através do qual poder-se-ia ... "compreender as dificuldades de modemização agrícola dos países em desenvolvimento, assim como explicar o dualismo tecnológico, antes como estágio do que como deficiência do processo". 
Ainda segundo Paiva (1975), "sob certas circunstâncias, o processo de modernização ficaria na dependência do desenvolvimento do setor não-agrícola, através de um mecanismo de autocontrole. Ou seja, da queda de preços do produto e dos fatores tradicionais, que faz com que as técnicas modernas vão-se tornando menos vantajosas à medida que se difundem. Ocorreria, assim, uma frenagem e um limite (grau máximo) ao processo de modernização. A partir desse limite, a modernização somente se expandiria com o crescimento do setor não-agrícola (e/ou exportação) a taxas capazes de absorver os aumentos de produção e os excedentes de mão-de-obra decorrentes do processo".

O principal elemento que une os vários modelos, em sua maioria, é a pressuposição de existência de dualismo tecnológico, seja de natureza intersetorial agricultura-indústria, seja intra-setorialmente, em termos da dicotomia agricultura moderna versus agricultura tradicional. Alguns modelos observam o progresso técnico enquanto etapas do processo de desenvolvimento econômico, que ocorre num horizonte temporal, outros, enquanto processo em que se verificam situações de desajustamentos.

A incorporação e a difusão do progresso técnico se propagam desuniforme e parcialmente, sugerindo a existência de vieses tecnológicos, dado que, do que se encontra na chamada "prateleira tecnológica", ou seja, do que está disponível, apenas frações desse estoque são utilizadas, e de forma diferenciada. Por esse motivo, ao se analisar dados do IBGE, referentes às tecnologias utilizadas nas principais lavouras, é possivel constatar que proporções diferenciadas de agricultores são responsáveis pela adoção de conjuntos específicos de práticas agrícolas. Concluindo, esses modelos tentam elucidar as razões pelas quais o processo de modemização se propaga desigualmente, gerando desequilibrios tecnológicos em nível de produtos, etapas do ciclo produtivo, agricultores e regiões.

\subsubsection{Pressupostos teóricos sobre o desenvolvimento em economias dualistas}

O objetivo desta seção é o de apresentar alguns modelos dualistas segundo as correntes teóricas que os fundamentam. Basicamente, têm-se duas 
abordagens: a clássica e a neoclássica. $\mathrm{O}$ fio condutor que permeia a exposição do assunto é o mercado de trabalho, a partir do qual, são derivadas as pressuposições teóricas.

Note-se que a tradição clássica, de Smith a Marx, aceitava a hipótese de oferta ilimitada de mão-de-obra a salários de subsistência. Tratava-se de explicar como a produção aumentava com o decorrer do tempo. Particularmente na análise marxista, o mecanismo que movimenta o processo é o de acumulação de capital.

Especificamente para Ricardo, "o salário é provido, ao nivel de subsistência, pelos meios de consumo que o setor agrícola é capaz de fornecer, a rendimentos decrescentes. $O$ progresso técnico, introduzido na produção de bens-salário, permite aumentar o excedente e favorece a acumulação. Mas esta termina por ser prejudicada pela expansão das margens de cultivo, que aumenta a renda paga aos proprietários da terra. Assim, o sistema se move no longo prazo, com salários rígidos e preços flexíveis..." (Tavares, 1974, p. 11).

Diferentemente de Ricardo, não haveria em Marx nenhuma idéia de rigidez de salários, dado que “... o próprio processo de acumulação e reprodução ampliada do capital esgotaria a reserva de mão-de-obra e seria necessário introduzir progresso técnico "poupador de mão-de-obra", para restabelecer a população relativa e conter a subida dos salários". "Por outro lado, subindo a produtividade da força de trabalho por cima do seu custo de reprodução, o progresso técnico geraria uma "maisvalia" acrescentada" (Tavares , 1974, p. 12-13).

A abordagem clássica, segundo Jorgenson (1975, p.138), pressupõe que exista um nivel de força de trabalho agrícola, além do qual, incrementos adicionais de mão-de-obra são redundantes. ${ }^{6}$ Além disso, considera fixa a taxa de salário, medida em bens agrícolas, enquanto houver desemprego disfarçado. Segundo essa corrente teórica, a força de trabalho agrícola precisaria diminuir, em termos absolutos, antes de terminar a fase de desemprego disfarçado.

\footnotetext{
- Existe redundância, quando a mão-deobra disponivel excede as exigências para um dado nivel de produto agricola.Em outras palavras, existe desemprego.
} 
Pressupõe-se, também, que o emprego e a produção no setor adiantado crescem à mesma taxa, enquanto houver mão-de-obra redundante no setor atrasado, isto é, a produtividade do trabalho permanece constante. $O$ capital cresce a uma taxa mais lenta do que a produção e o trabalho de maneira que a relação capital-trabalho diminui. As taxas de crescimento da produção industrial, emprego e capital crescem durante a fase de desemprego disfarçado.

Segundo Ruttan (1975, p.163), “os mais novos modelos dinâmicos da economia dualista identificam a agricultura como setor tradicional e a indústria como setor moderno e tentam traçar a interação crescente entre os dois setores no processo de desenvolvimento". Este tipo de abordagem fora iniciado por Lewis (1954), em seu artigo sobre "Desenvolvimento Econômico com Oferta Ilimitada de Trabalho".

Na falta de outro referencial, a análise de países com excedente de mãode-obra precisaria retroceder à tradição clássica. Este é o objetivo de Lewis, que aproveita o marco teórico clássico para resolver os problemas de distribuição, acumulação e crescimento. Segundo esse autor, ...“a proposta não é a de superar a economia neoclássica, mas, simplesmente, elaborar esquema diferente para aqueles que não podem ser encaixados dentro das hipóteses neoclássicas, nem Keynesianas. ... " Há ilimitada oferta de trabalho nos países onde a população é tão numerosa em relação ao capital e aos recursos naturais, que existem amplos setores da economia em que a produtividade marginal do trabalho é ínfima, nula, ou mesmo negativa". Nesse sentido, ... “o preço do trabalho nessas economias, corresponde ao nível de subsistência... A esse preço, a oferta é ilimitada porque excede a demanda".

Lewis (1954), citado por Jorgenson (1975, p. 140), aponta ..."ser raro o desemprego disfarçado na África e na América Latina, mas ele se repetiria na China, na Indonésia, no Egito e em muitos países da Europa Oriental, sendo que mais da metade da população mundial, principalmente na Ásia e na Europa Ocidental, viveria em condições que correspondem às pressuposições clássicas e não neoclássicas”.

Após Lewis, a abordagem clássica foi retomada, entre outros autores, por Fei \& Ranis, cujo modelo, citado por Ruttan (1975, p.166), caracteriza o setor de subsistência por: a) desemprego e subemprego disfarçados; b) produtividade marginal da 
mão-de-obra igual a zero; c) taxa salarial para a mão-de-obra positiva "determinada institucionalmente", que se aproxima da produtividade média da mão-de-obra no setor de subsistência; d) insumos fixos da terra. O suporte empírico desses autores foi extraido, em grande parte, da experiência japonesa, no século XIX, e da Índia contemporânea.

Como resultado, a transferência de mão-de-obra da agricultura para o setor urbano-industrial não reduziria a produção agrícola, nem aumentaria o preço da oferta de trabalho ao setor industrial. Mais ainda, essa transferência acarretaria a geração de um excedente agrícola que seria apropriado para o desenvolvimento do setor dinâmico. Esse excedente também poderia ser oriundo da incorporação de progresso técnico no setor de subsistência. Dessa maneira, "a agricultura contribuiria com trabalhadores e com excedente de produção na forma de um "fundo salarial" para a expansão do setor industrial".

Essa articulação intersetorial agricultura-indústria funcionaria enquanto o valor do produto marginal não fosse maior do que zero. A partir desse novo estágio, a transferência de trabalhadores não liberaria um "fundo salarial" suficiente para suportar seu consumo no setor urbano, resultando na deterioração dos "termos de comércio", passivel de ser compensada pelo aumento da produtividade e declínio na taxa de crescimento populacional no setor industrial. (Ruttan, 1975, p. 167).

"O segundo ponto ocorre quando o valor do produto marginal da mãode-obra excede a taxa salarial "determinada institucionalmente" no setor agrícola. Nesse ponto, um aumento na taxa salarial industrial é exigido se esse setor está competindo efetivamente com o de subsistência pela mão-de-obra. Se, nesse estágio, um crescimento de produtividade rápido é obtido no setor agrícola, as características dualistas da economia atrofiam-se e a agricultura assume crescentemente o papel de apêndice de uma economia de um só setor em seu todo". (Ruttan, 1975: 167).

O método clássico de abordagem se reduz ao neoclássico, depois que a fase de desemprego disfarçado é completada. Nesse sentido, ambos os métodos têm 
implicações diferentes somente quando ainda é alegada a existência de desemprego dissimulado. $^{7}$

Uma das críticas de Jorgenson (1975) é dirigida ao método indireto, de estimativa do excedente de mão-de-obra, base do argumento de Lewis. $O$ cálculo do emprego disfarçado é obtido pela diferença entre o total de mão-de-obra disponível e o total exigido pelo processo produtivo, sem serem consideradas as variações sazonais de emprego agrícola. Quer dizer, a mão-de-obra pode ficar desempregada durante certo periodo do ano sem ser redundante. Em sendo assim, somente poderia existir redundância, se o cálculo fosse feito tomando-se o período de demanda máxima de trabalho. Caso contrário, o chamado desemprego disfarçado poderia estar sendo superestimado.

Segundo Jorgenson (1975, p.142), quando essas estimativas são corrigidas, levando-se em consideração a demanda estacional de trabalho agrícola, a situação no Sudeste da Europa, Egito, China e Sudeste da Ásia parece ser mais de déficit do que de excedente de mão-de-obra.

Através de uma série de evidências empíricas, extraidas do exame de casos históricos realizado por Schultz $^{8}$ (1956 e 1964) e de estudos antropológicos analisados por Oshima ${ }^{9}$ (1958), ambos citados por Jorgenson (1975, p.142-143) vai-se fundamentar a não existência de desemprego disfarçado. Nesse sentido, Jorgenson $(1975$, p. 145) conclui que "esta evidência não demonstra que o desemprego disfarçado nunca existe em nenhuma circunstância histórica ou geográfica, mas somente que o

\footnotetext{
${ }^{7}$ Para Tavares, (1974, p.70-72), “... as hipóteses clássicas e neoclássicas de introdução do progresso técnico não teriam maior relevância explicativa para os países subdesenvolvidos... "Apesar da supapopulação relativa permamente, nos paises subdesenvolvidos, o progresso técnico poderia poupar mão-de-obra, independentemente de que não se necessite aumentar o "exército industrial de reserva", como no modelo clássico marxista O problema não se põe tampouco, como na visão neoclássica de alocação de recursos a parti dos custos altemativos de fatores de produção vis a vis a sua escassez relativa ...". "Para as economias subdesenvolvidas o problema da "escolha das técnicas", tal como vem sendo colocado à luz da dotaçâo relativa de fatores produtivos é, pois, um falso problema $O$ verdadeiro problema está na escolha de produtos, e por derivação, na modificação da estrutura de produção que afeta e diferencia a estrutura de demanda".

${ }^{8}$ A análise de Schultz está relacionada ao exame de casos históricos em que grande parte da mão-de-obra foi retirada por um curto periodo de tempo, levando á queda da produção agricola: Peru, India e Belo Horizonte. Referido, também, por Jorgenson, mencione-se outro trabalho de Schultz, com base na experiência da Guatemala e da Índia, cuja conclusão é a de que "em nenhuma parte a força de trabalho na agricultura, nessas comunidades, teria, produtividade marginal igual a zero".

O estudo de Oshima, sobre 18 trabalhos referentes à Índia, China e Sudeste da Ásia contesta a existência de mão-de obra redundante.
} 
campo de aplicação do método de abordagem clássico, ao desenvolvimento em economias dualistas é extremamente limitado. Especificamente, as pressuposições clássicas não são aplicáveis à América Latina, África, Sudeste da Europa, Índia, China ou ao restante do Sudeste da Ásia".

Outro pressuposto da abordagem clássica rebatido por Jorgenson (1975) é a existência de uma taxa salarial fixa. Para o autor, com base em dados da renda real por membro da força de trabalho, no Japão, no período 1878-1917, “a pressuposição de uma taxa de salário real constante no setor agrícola é inconsistente com a evidência empirica".

Contesta, também, o argumento clássico de que a força de trabalho precisaria diminuir, em termos absolutos, antes de terminar a fase de desemprego disfarçado. Para o autor, as experiências européia e japonesa revelaram que o desenvolvimento econômico se deu com força de trabalho constante ou com aumento moderado. "Em resumo, reduções em valores absolutos na força de trabalho agrícola ocorrem depois que a industrialização é progressivamente mais intensiva do que nos estágios iniciais do processo".

Os demais pressupostos sobre produtividade constante do trabalho no setor adiantado, queda da relação capital-trabalho e aumento das taxas de crescimento da produção industrial, emprego e capital, durante a fase de desemprego disfarçado são também contestados. Jorgenson (1975) conclui que a evidência do desenvolvimento japonês, de 1878-1917, apóia o método neoclássico mais do que o clássico. As pressuposições básicas e as implicações do método clássico são inconsistentes com a evidência.

Em termos opostos, a abordagem neoclássica pressupõe que a produtividade marginal da mão-de-obra seja sempre positiva e que o fator trabalho nunca seja redundante.

Outros pressupostos são: a taxa de salário real é variável; a força de trabalho agricola pode crescer, diminuir ou permanecer constante; o emprego industrial cresce mais lentamente do que a produção e o capital de maneira que a produtividade do trabalho no setor adiantado cresce; o capital e a produção no setor adiantado crescem à 
mesma taxa, assintoticamente, fazendo com que a relação capital -produto permaneça constante; as taxas de crescimento da produção industrial e do emprego decrescem através do processo de desenvolvimento.

Considere-se que, através da abordagem neoclássica, não se procurava explicar a expansão do sistema através do tempo. 'Essa mudança de enfoque era adequada à Europa, onde havia limitação de mão-de-obra e se tinha a impressão que a expansão econômica poderia ser vista como automática. Na Ásia havia oferta ilimitada de mão-de-obra, mas isso atraia poucos economistas. Os próprios asiáticos acompanhavam as suposições da economia européia" (Lewis, 1954).

O modelo de economia dualista de Jorgenson incorpora as pressuposições da abordagem neoclássica. Segundo Ruttan (1975, p. 167), nesse modelo, “as taxas salariais são determinadas em um mercado intersetorial de mão-de-obra, mesmo durante os estágios iniciais de desenvolvimento. Como resultado, a mão-de-obra nunca está disponivel para o setor industrial sem o sacrificio da produção agrícola e os termos de comércio movem-se continuamente contra o setor industrial ao longo de todo o processo de desenvolvimento e não somente depois de seu substancial crescimento".

A criação de excedentes agrícolas dependeria de: a) taxa de progresso técnico na agricultura; b) taxa de crescimento populacional, onde a população não é limitada por falta de alimentos; c) elasticidade da produção no setor agrícola com respeito à mudança na força de trabalho agricola.

O modelo de Jorgenson exige mudança tecnológica no setor agrícola desde o início do processo de crescimento, para criação de excedente, enquanto que, no modelo de Fei \& Ranis, só depois que a produtividade marginal do trabalho for superior à taxa salarial.

Resumidamente, os dois modelos levam a concluir que uma mudança nos termos de comércio a favor da agricultura compromete o crescimento e isso só pode ser compensado por combinações de: a) aceleração na taxa de mudança tecnológica na agricultura; b) redução do crescimento populacional.

Ruttan (1975) aponta um conjunto de limitações em ambos modelos: a) ignoram o problema do uso de recursos nos mercados intersetoriais de bens; b) 
consideram apenas a mudança na demanda por mão-de-obra como resultado dos ganhos de produtividade na agricultura. Ignoram a mudança na demanda de outros insumos, embora a mudança tecnológica seja "tipicamente canalizada para o setor agrícola na forma de insumos como fertilizantes e inseticidas que são comprados do setor nãoagricola"; c) pressupõem economia fechada; d) a função de produção para o setor agricola inclui só a terra (fixo) e mão-de-obra e, para o setor industrial, somente capital e mão-de-obra, o que nem sempre é apropriado. Além disso, a terra pode ser produzida pela introdução de bens de capital, logo não seria um recurso fixo.

\subsection{Dualismo na agricultura pernambucana}

A caracterização do dualismo, em termos da existência de diferenciação tecnológica ou coexistência de um setor moderno com outro tradicional, aplica-se à agricultura pernambucana: essa dualidade pode ser captada através de suas várias faces.

De início, cabe observar as diferenças tecnológicas entre mesorregiões e dentro dessas próprias macro-unidades. Na Zona da Mata, a cultura canavieira sempre representou a lavoura mais importante, considerando-se seu peso em termos da contribuição para a economia estadual, bem como pela incorporação tecnológica, tomando-se o segmento sucroalcooleiro como um todo.

Apesar da defasagem tecnológica desse segmento em relação a outros centros produtores mais adiantados - o que já representaria outra dualidade -, dentro do estado, essa dicotomia tem existência, principalmente, pela disseminação interior adentro, notadamente no Agreste, da policultura alimentar, juntamente com a pecuária. Foram-se conformando dois setores bastante distintos tecnologicamente: a "plantation" e a produção de "subsistência". Ao longo do tempo, grosso modo, poder-se-ia dizer da ocorrência de um viés de modemização direcionado a cana-de-açúcar, e principalmente, ao segmento industrial. Através desse último aspecto, caberia a identificação de outro dualismo.

A partir dos anos 1950, passa a ocorrer outro viés de modernização, através da introdução e expansão de novas culturas no Agreste: hortaliças, frutas e 
flores. Verifica-se, também, crescente melhoria nos padrões da atividade pecuária, tomando-a cada vez menos extensiva. Esse redirecionamento vem em resposta aos estímulos do mercado consumidor oriundos do crescimento do setor urbano. Instrumentos de políticas de governo passam a estimular essas atividades. $O$ reordenamento espacial do uso das melhores terras da mesorregião Agreste, que se traduziu em processo de substituição de culturas, paralelamente à inserção produtiva de terras ociosas, injeta novo dualismo representado pelas culturas de "subsistência" versus culturas ou atividades de "mercado", relativamente mais evoluidas tecnologicamente.

Na mesorregião Sertão, o viés tecnológico da modernização ocorrerá, também a partir dos idos dos anos 1950, pelo endereçamento dos estímulos provenientes das políticas dos governos à conformação de um novo setor, representado pela agricultura irrigada ao longo do São Francisco. Passa a existir forte dualidade tecnológica, onde o moderno corresponde ao novo setor, em coexistência com o antigo e tradicional: a pecuária extensiva e a policultura alimentar, que se encontram disseminadas tanto na própria microrregião do São Francisco, como em toda a mesorregião Sertão. Além disso, estabelece-se uma interatividade forte entre os dois setores, no mercado de trabalho, cabendo ao tradicional o fornecimento de mão-de-obra, principalmente a de natureza sazonal.

São diferenças tecnológicas vistas sob o prisma de culturas e da localização geográfica. Nesses aspectos, acrescente-se que as culturas modernas exibem maior concentração regional da produção: dominam toda uma mesorregião, como exemplifica a lavoura da cana-de-açúcar na Mata Pernambucana, ou estão insuladas em pequenas áreas, a exemplo da hortifruticultura nos brejos agrestinos, ou assemelham-se a enclaves ou "bolsões de modemização", como a agricultura irrigada do São Francisco.

No âmbito dessa dicotomia tecnológica entre culturas, espacialmente estratificadas, observa-se que a modernização tem ocorrido de forma mais significativa em direção a produtos que se destinam à industrialização (cana-de-açúcar), exportação (fruticultura do Vale do São Francisco), ou ao consumo de segmentos da população de maior poder aquisitivo (alguns produtos nobres da horticultura podem ser exemplos). 
Essa modemização excludente tem ocorrido através do concurso dos mecanismos de política, que se mostraram bastante seletivos quanto ao que e a quem financiar. Em outras palavras, as políticas acarretaram o aparecimento ou acentuação do dualismo, em cada caso, dependendo da microrregião que se trate. Em conseqüência, a modernização propagou-se desigualmente no espaço agrário, aumentando os desequilibrios tecnológicos entre regiões, agricultores, culturas e etapas dos ciclos.

A agricultura pernambucana, no contexto estadual, ainda pode ser considerada predominantemente de baixo nível tecnológico, tomando-se a escassa adoção de modernas práticas agrícolas, tendo-se como referência a massa de agricultores e o conjunto total de estabelecimentos. Em face dessa característica, o dualismo, no caso específico, tem a peculiaridade de expressar-se pela coexistência de um setor moderno, concentrado ou fracamente difuso, com outro setor, tradicional, ainda amplamente disseminado, ao qual corresponde a grande parte do universo de estabelecimentos e agricultores. 


\section{CARACTERIZAÇÃO DA MODERNIZAÇÃO AGRÍCOLA EM PERNAMBUCO}

O processo de modemização tecnológica da agricultura pernambucana vinha se manifestando, desde os anos 50, através da agroindústria da cana-de-açúcar e da pecuária. A pequena produção de alimentos básicos, especialmente o feijão, mandioca e milho, ficaram relativamente à margem desse processo. A literatura tem freqüentemente atribuido o acesso diferenciado de agricultores e lavouras aos instrumentos de política agricola, em especial o crédito que vigorou de maneira bastante seletiva e subsidiada nos anos 1970, como uma das causas principais desse processo de modernização desigual. Somam-se, também, o direcionamento seletivo da pesquisa, da assistência técnica e extensão, além de todo um aparato institucional envolvendo órgãos e políticas especificas, notadamente para a cana-de-açúcar e as lavouras irrigadas da mesorregião Sertão. Isto contribuiu para o avanço tecnológico e maior rentabilidade e competitividade de determinados subsetores, a exemplo dos citados, em detrimento de outros como o dos alimentos básicos.

Entretanto, como exceção à regra, sobressaem-se os produtos da horticultura e da fruticultura, que se comportam dinamicamente tanto pela incorporação de tecnologia modema, quanto pelo crescimento da produção e produtividade, os quais tem sido beneficiados com mais intensidade por políticas govemamentais.

Analisando-se dados do periodo 1950/1980, apresentados na tabela 3.1, verifica-se que apenas a cana-de-açúcar e o tomate tiveram aumento de produtividade. Ao contrário, os alimentos básicos, bem como o algodão, apresentaram queda no rendimento físico. Paralelamente, a área cultivada desses produtos manteve-se 
relativamente estável no periodo, enquanto que a cana-de-açúcar teve sua área mais do que dobrada.

Tabela 3.1. Área colhida (hectares), quantidade (toneladas) e rendimento médio (toneladas/hectare), segundo culturas. Pernambuco, 1950/1980.

\begin{tabular}{lrrrrrr}
\hline \hline & \multicolumn{1}{c}{1950} & & \multicolumn{1}{c}{1980} \\
& Área & \multicolumn{1}{c}{ Quant. } & Rendimento & Área & Quant. & Rendimento \\
\hline Cana-de-açúcar & 174.369 & 4.997 .864 & 28,7 & 380.509 & 17.972 .726 & 47,2 \\
Algodão & 177.928 & 38.335 & 0,2 & 178.731 & 21.171 & 0,1 \\
Feijão & 252.352 & 74.062 & 0,3 & 274.568 & 63.172 & 0,2 \\
Milho & 262.603 & 146.465 & 0,6 & 270.016 & 91.570 & 0,3 \\
Mandioca & 78.735 & 708.846 & 9,0 & 75.341 & 576.879 & 7,7 \\
Tomate & 3.526 & 34.107 & 9,7 & 4.924 & 78.090 & 15.9 \\
\hline \hline
\end{tabular}

Dados Brutos: IBGE. Censo Agrícola de 1950; IBGE. Censo Agropecuário de 1980.

Os processos de alteração da composição da produção, de mudança do padrão geográfico das culturas, e simultaneamente, de modernização seletiva das lavouras, aceleraram-se a partir do início dos anos 1960: expande-se a demanda urbana, concomitantemente ao aumento do fluxo migratório sentido rural-urbano. Em conseqüência, viabiliza-se o aumento da oferta de carne bovina, leite e derivados, lastreando o processo de pecuarização. Do lado agricola, cresceram a demanda e a produção dos hortifrutigranjeiros. A ampliação e melhoria da malha viária contribuíram para a expansão dos mercados, bem como para uma especialização inter-regional.

Apesar de ter havido mudanças estruturais na produção agricola, o Estado de Pernambuco continua dependente da monocultura canavieira. Trata-se do setor economicamente mais importante. Também relevante, continua a ser a produção dos alimentos básicos, tanto em geração de valor, quanto pela área ocupada, e o grande número de agricultores e estabelecimentos envolvidos. São bastante estratégicos, pois representam a subsistência desses agricultores. Frustrações de safra ocasionam o recrudescimento dos fluxos migratórios, com efeitos perversos para o setor urbano. 
A série histórica de dados, exposta na tabela 3.2, revela uma queda gradativa da participação dos produtos destinados à transformação industrial (cana-deaçúcar, algodão, café e agave), ao mesmo tempo em que cresceu a participação do subsetores alimentos básicos e hortifruticultura. No de transformação industrial, essa queda pode ser debitada ao declínio das lavouras do grupo, excetuando-se a cana-deaçúcar, que aumenta a sua participação: em 1979, representava $85 \%$ do valor total da produção vegetal do grupo, contra 34\%, em 1950.

Tabela 3.2. Distribuição percentual do valor bruto da produção vegetal segundo o tipo e a destinação da produção. Pernambuco, 1950/79.

\begin{tabular}{ccccc}
\hline Triênios & $\begin{array}{c}\text { Produtos para } \\
\text { transformação industrial }\end{array}$ & Alimentos básicos & Hortifruticultura & Total \\
\hline $1950 / 51 / 52$ & 66,2 & 26,1 & 7,7 & 100,0 \\
$1956 / 57 / 58$ & 60,7 & 26,8 & 12,5 & 100,0 \\
$1963 / 64 / 65$ & 57,3 & 30,2 & 12,5 & 100,0 \\
$1970 / 71 / 72$ & 48,9 & 38,0 & 13,1 & 100,0 \\
$1977 / 78 / 79$ & 50,1 & 34,6 & 15,3 & 100,0 \\
\hline \hline
\end{tabular}

Dados brutos: SERPE. Amuários Estatisticos de Pemambuco, 1950-72, IBGE. Censo Agropectúnio de 1970 e Produção Agricola Municipal, 1973-79.

Como mencionado, um dos principais instrumentos que contribuiu para o processo de modernização agrícola foi o crédito rural, principalmente na década dos anos 70. Os dados da tabela 3.3, para o período 1974/81, revelam que a lavoura que mais recebeu crédito de custeio foi a da cana-de-açúcar, carreando $64,4 \%$ dos recursos. Os produtos da horticultura e os alimentos básicos aparentemente foram igualitariamente discriminados. Mas, um exame detalhado dos dados referentes à distribuição do crédito vai provar o contrário. Isto porque, os alimentos básicos são produzidos em vasta área territorial, através de uma quantidade de estabelecimentos significativamente maior que os da horticultura, diluindo os recursos. 
Apresentando, também, participação menos expressiva, em termos de área e estabelecimentos, porém não bem captada através dos dados da tabela 3.3, encontra-se a fruticultura: o setor contém relativa diversidade tecnológica, e para alguns de seus produtos, a exemplo da viticultura, tem havido linhas especificas de crédito.

Calculando-se a razão entre o número de contratos e o total de estabelecimentos próprios, obteve-se o seguinte resultado: cana-de-açúcar (1 contrato por estabelecimento); horticultura $(0,8)$; uva, arroz e algodão $(0,2)$; feijão $(0,1)$; milho $(0,04)$; frutas diversas $(0,03)$; mandioca $(0,02)$. Desta forma, conclui-se que, aparentemente, tiveram mais acesso ao crédito, a cana-de-açúcar e os produtos da horticultura, conforme indicam esses dados expostos na tabela 3.3.

Tabela 3.3. Distribuição percentual do crédito de custeio entre os principais produtos agricolas. Pernambuco, 1974/81.

\begin{tabular}{lccc}
\hline \multicolumn{1}{c}{ Produtos } & $\mathbf{1 9 7 4 / 7 7}$ & $\mathbf{1 9 7 8 / 8 1}$ & $\mathbf{1 9 7 4 / 8 1}$ \\
\hline Cana-de-açúcar & 79,7 & 52,4 & 64,4 \\
Hortifruticolas & 3,8 & 9,2 & 6,7 \\
Feijão & 4,2 & 12,5 & 8,8 \\
Milho & 2,7 & 6,9 & 5,1 \\
Mandioca & 0,9 & 4,0 & 2,6 \\
Arroz & 0,4 & 0,8 & 0,5 \\
Algodão & 3,2 & 5,5 & 4,5 \\
\hline \hline
\end{tabular}

Dados brutos: Ministéno da Agricultura COMCRED. Crédito Rural, 1969776. Vol. IV (NORDESTE); Banco Central do Brasil/DERUR Crédito Rural, Dados Estntisticos: 1977-81.

A tabela 3.4 revela o valor médio por contrato para as lavouras anteriormente mencionadas. A cana-de-açúcar apresenta os contratos de maior valor, seguindo-se as culturas da uva, arroz, das frutas em geral e das hortaliças, considerandose o periodo inteiro 1974-81. De outra parte, os contratos de menor valor são exibidos em ordem decrescente pelas culturas do algodão, mandioca, feijão e milho. 
Tabela 3.4. Valor médio por contrato de crédito para os principais produtos agrícolas de Pernambuco, segundo quadriênios $(1974-77$; 1978-81) e o período $1974-81$ (média em Cr\$ constantes, Base 1965/67=100).

\begin{tabular}{lrrr}
\hline \hline \multicolumn{1}{c}{ Produtos } & $\mathbf{1 9 7 4 / 7 7}$ & $\mathbf{1 9 7 8 / 8 1}$ & $\mathbf{1 9 7 4 / 8 1}$ \\
\hline Cana-de-açúcar & 21.501 & 24.496 & 22.999 \\
Hortaliças & 3.596 & 3.385 & 3.491 \\
Frutas & 3.591 & 3.892 & 3.742 \\
Uva & 6.333 & 23.728 & 15.031 \\
Feijão & 1.239 & 1.348 & 1.294 \\
Milho & 2.643 & 3.147 & 2.895 \\
Mandioca & 1.043 & 1.419 & 1.231 \\
Arroz & 3.305 & 4.476 & 3.891 \\
Algodão & 933 & 1.352 & 1.143 \\
\hline \hline
\end{tabular}

Dados brutos: Ministénio da Agricultura COMCRED. Crédito Rural, 1969/76. Vol. IV (NORDESTE); Banco Central do Brasil/DERUR Crédito Rural, Dados Estatisticos: 1977-81.

Outra linha de crédito destinava-se à aquisição de insumos subsidiados. Dados para o periodo 1974/81, evidenciados na tabela 3.5, também confirmam a canade-açúcar como a lavoura que mais recebeu recursos do crédito oficial: $96,5 \%$ e $67,3 \%$ dos recursos destinados à aquisição de corretivos/fertilizantes/inoculantes e de defensivos, respectivamente. Em seguida, vem a hortifruticultura, particularmente no que se refere à aquisição de defensivos (25\%) e sementes e mudas melhoradas (19,6\%). Considerando-se essa última dupla de insumos, a cultura do feijão carreou a maior parte dos recursos, cerca de $60 \%$, indicando a tentativa do Governo em melhorar a produtividade através de inovações biológicas, embora esse progresso não se tenha refletido nos dados. 
Tabela 3.5. Distribuição percentual do crédito destinado à aquisição de insumos subsidiáveis entre os principais produtos agrícolas. Pernambuco, 1974-81.

\begin{tabular}{lccc}
\hline \multicolumn{1}{c}{ Produtos } & $\begin{array}{c}\text { Corretivos, Fertilizantes } \\
\text { e Inoculantes }\end{array}$ & Defensivos & $\begin{array}{c}\text { Sementes e mudas } \\
\text { melhoradas }\end{array}$ \\
\hline Cana-de-açúcar & 96,5 & 67,3 & 8,8 \\
Hortifrutícolas & 2,4 & 25,0 & 19,6 \\
Feijão & 0,6 & 1,7 & 61,1 \\
Milho & 0,1 & 1,1 & 4,0 \\
Mandioca & - & - & - \\
Arroz & 0,2 & 2,7 & 1,7 \\
Algodão & 0,02 & 2,1 & 4,7 \\
\hline \hline
\end{tabular}

Dados brutos: Ministéno da Agricultura COMCRED. Crédito Rural, 1969/76. Vol IV (NORDESTE); Banco Central do Brasil/DERUR Crédito Rural, Dados Estatisticos: 1977-81.

Dessa problemática introdutória, juntamente com outros elementos que serão adicionados na caracterização microrregional, pode-se listar, resumidamente, um conjunto de fatores que deram existência e movimento ao processo de modernização: urbanização; estabelecimento de infra-estrutura (rodovias, mercados atacadistas, irrigação); crédito rural, pesquisa e extensão; desregulamentação de setores e abertura comercial; condições edafo-climáticas locais; e caráter preexistente diferenciado das estruturas de produção microrregionais.

Esses fatores contribuíram na identificação e seleção de variáveis, alguns dos quais são os próprios indicadores, a exemplo dos financiamentos agrícolas. Nesse sentido, causa e efeito sobre a modernização reduzem-se a um só elemento. Isto é, o indicador crédito, a título de exemplo, hipoteticamente estará sendo tomado como ingrediente causador modemizante, e o grau de participação no crédito, como efeito explicativo do nível de modernização.

Parte desse conjunto de fatores, condicionada à disponibilidade e pertinência de dados, foram desmembrados em variáveis específicas, das quais foram 
extraídos os fatores sintéticos ou índices, reveladores dos níveis ou estágios diferenciados de modernização.

A diferenciação tecnológica poderia ser examinada sob várias óticas: geográfica, de agricultores, e de sistemas agrários ou de lavouras específicas, tendo por base dados das unidades de produção, disponíveis nos Censos. Entretanto, privilegiou-se a primeira, através do exame da diferenciação microrregional da modernização.

A manifestação do fenômeno modernização foi capturada pelo comportamento das variáveis indicadoras do processo, em cortes temporais. Basicamente, são variáveis relativas à estrutura de funcionamento da unidade de produção, tendo como referência à base técnica, as relações de produção, a utilização da terra, o acesso aos instrumentos de política, etc. Indicaram, isoladamente, e principalmente, a partir de estruturas de correlação dessas variáveis - em face da técnica estatística adotada -, intensidade da exploração, relação capital/trabalho, relações de trabalho, e, genericamente, modernização.

\subsection{A Modernização na Mesorregião da Mata}

A mesorregião Mata Pernambucana abrange parte do litoral e da faixa úmida costeira, conhecida também como zona canavieira. Até o Censo de 1985, estava composta pelas microrregiões Mata Seca e Mata Úmida ${ }^{10}$. Considerando-se a distribuição espacial de sua principal atividade econômica, a da agroindústria sucroalcooleira, pode-se acrescentar-lhe a microrregião homogênea Recife.

Segundo relatório do Conselho de Desenvolvimento de Pernambuco (CONDEPE, 1991, p.15-16), “ao contrário do Agreste, na Mata existe um grande domínio do latifúndio por exploração ${ }^{11}$, frente a outras categorias de imóveis, sendo natural que dominem atividades que interessem à grande propriedade, neste caso a cana-

\footnotetext{
${ }^{10}$ A partir do Censo de 1995/96, a estrntura microrregional sofreu alteraçōes, passando a mesortęjão Mata Pernambucana a conter as microrregiões: Mata Setentrional, Mata Meridional e Vitóna de Santo Antão.

${ }^{11}$ Zoneamento agrário realizado pelo INCRA/SERPRO (1978, p.25), com o objetivo de Reforma Agránia, identificou no País... "124 microrregiões, nas quais metade da área cadastrada é formada por imóveis nurais de área igual ou superior a 500 hectares, sendo que naquele número se incluem microrregiōes densamente povoadas, como as da zona da Mata de Pemambuco, Alagoas e Paraiba.."
} 
de-açúcar”. Cultivam-se também a banana, o coco, e desenvolve-se a atividade pecuária. Mas o principal uso da terra refere-se às lavouras temporárias, ocupando $58 \%$ da área total (IBGE, 1985), principalmente a cana-de-açúcar, seguida das pastagens, com predomínio das naturais. As lavouras permanentes representam a terceira atividade de destinação das terras.

A modernização da economia canavieira pernambucana desenvolveu-se lentamente. Afora o seu período de apogeu, no Brasil colonial, o nível tecnológico desse setor ficou sempre aquém dos outros mercados produtores que foram se inserindo no comércio do açúcar.

A partir dos anos 1930, os preços subsidiados e a reserva de mercado, regulamentados pelo Governo Federal, para proteger a atividade nordestina da concorrência, retardaram o ritmo adequado de modernização que seria normalmente imposto a um mercado livre. Ou seja, o protecionismo estatal contribuiu indiretamente para a continuação de um diferencial de custos de produção, comparativamente a outros centros ofertantes como do Centro-Sul. Além disso, a modemização do setor foi mais acelerada no segmento industrial, do que no agrícola. $\mathrm{O}$ esgotamento progressivo dos solos, apesar do recurso do pousio das terras como alternativa à adubação, levou indiretamente a uma queda do rendimento industrial.

Com a desregulamentação, e, principalmente, a diminuição do protecionismo ao setor, a partir dos anos 1990 a economia canavieira pernambucana entrou em profunda crise, com a falência e fechamento de usinas, redução da área plantada e da produtividade. Esse quadro de deterioração econômica tem levado a um processo de reocupação de uma parcela das terras, que ficaram ociosas, pelo movimento de Reforma Agrária. No segmento das usinas que têm resistido à crise, vem-se verificando um processo de modemização forçada, através da redução de custos, investimentos em pessoal e aumento da produtividade, automatizando-se a produção do açúcar e álcool, e adotando-se melhorias tecnológicas na lavoura.

A contextualização do desenvolvimento histórico da atividade, a seguir, vai explicitar os mecanismos de dependência assegurados pelo protecionismo federal. Os trabalhos de Dantas (1971), Dantas \& Silva (1995) e do CONDEPE (1991) fornecem 
a cronologia dos fatos econômicos da atividade em seu caminho de dependência do setor público.

À época do início de sua implantação, dadas às condições históricas de isolamento em que se encontrava a cana-de-açúcar em Pernambuco, a unidade de produção se verticalizava, tornando-se auto-suficiente dos insumos necessários à produção, bem como dos gêneros destinados à força de trabalho. Esse quadro de autosuficiência pouco se alterou até o final da primeira metade do século $\mathrm{XX}$.

A partir dos anos 1960, vai-se extinguindo a figura do morador, na verdade um trabalhador rural disfarçado, que habitava e plantava em pequenos sítios situados dentro dos latifúndios canavieiros, em troca do trabalho seu e de sua família na lavoura da cana. Essa força de trabalho vai ser expulsa para fora dos domínios da grande exploração, estabelecendo-se em vilas e arruados. Um dos motivos foi o temor de uma reordenação fundiária, em função do movimento social crescente de camponeses, e em face da aprovação do Estatuto da Terra. Não se pode atribuir, portanto, apenas à substituição do engenho pelas usinas, a mudança nas relações de trabalho.

Considere-se também que o surgimento das primeiras usinas, conhecidas inicialmente como engenhos centrais, aconteceu no final do século passado. A partir daí, pouco a pouco, os "senhores de engenho" foram deixando o segmento da transformação industrial da matéria-prima, para se tornarem apenas fornecedores. Ao longo do tempo, à medida que se ampliava a sua produção, as usinas aumentavam as plantações de canas próprias e, para isso, adquiriam cada vez mais terras, criando, desse modo, os grandes latifúndios hoje conhecidos, resultantes, em muitos casos, da mera aglutinação de engenhos individuais (Dantas, 1971, p.35).

O início da intervenção do Governo Federal aconteceu a partir das crises de excesso de produção, particularmente da safra de 1929/1930. Para evitar o colapso, o Governo decretou em 1931, a retenção obrigatória de $10 \%$ da produção, com o fim de regular o mercado e o preço, e no mesmo ano, criou a Comissão de Defesa da Produção do Açúcar (COMDECAR). Em seguida, em 1933, os frutos da política dessa comissão levaram à criação do Instituto do Açúcar e do Álcool. "A atuação do IAA, fundamentalmente conservadora e sempre no sentido de preservar o sistema, não 
estimulou qualquer transformação estrutural apreciável e por isso não o preparou para as transformações profundas, que dele seriam exigidas 30 anos depois" (Dantas, 1971, p.35).

Na segunda metade do século $\mathrm{XX}$, inicia-se um processo de perda dos mercados internos. Dada a insatisfação do mercado consumidor do Centro-Sul, ao declínio da citricultura, em função de uma doença nova, e dos velhos cafezais, instalamse nas melhores terras roxa, um moderno centro produtor de açúcar. No final dos anos 1950, a produção paulista de açúcar já ultrapassara a de Pernambuco.

Para impedir o colapso inevitável da maioria das unidades produtoras do Nordeste, que se encontravam sem preço e sem mercado, fixou-se um preço único nacional, que permitisse recolher, da produção do Centro-Sul, uma taxa que se reverteria em favor da produção nordestina. Em 1966, verificou-se que os subsídios não estavam oferecendo os resultados esperados, pois o diferencial de custos era consideravelmente mais elevado, além das resistências dos produtores paulistas em recolher a taxa. A solução encontrada foi a fixação de preços distintos para ambas regiões, acompanhada da divisão do mercado nacional, ficando os consumidores da Bahia até a Amazônia obrigados a se abastecerem do açúcar nordestino.

A partir da primeira metade dos anos 1970, a agroindústria canavieira de Pernambuco experimentou considerável progresso, em função da crise da oferta mundial do açúcar, que acarretou consistente elevação dos preços externos, permitindo a concessão de generosos subsídios aos preços internos e a ampliação do programa de modernização e ampliação do setor. Na segunda metade dos anos 1970, foi restabelecido o equilibrio do mercado mundial, com retorno dos preços externos a níveis normais, geralmente inferiores aos custos locais. Ao mesmo tempo, também em função da crise do petróleo, é criado o PROÁLCOOL, em 1975, estimulando-se a construção de destilarias anexas às usinas e de destilarias autônomas, ampliando-se a área dos canaviais (Dantas \& Silva, 1995).

Após a Constituição de 1988, tornou-se inviável a reserva de mercado, assegurada pela Lei de 1965, que garantia o consumo do açúcar local nos mercados do Norte e Nordeste, a salvo da concorrência do produzido nos estados do Centro-Sul. A 
partir de 1990, a política econômica federal de contenção de despesas, induzida pela crise financeira do Estado, inviabilizou a concessão de subsídios às usinas pernambucanas. (Dantas \& Silva, 1995). A extinção do IAA, e, em 1997, a liberação dos preços da cana-de-açúcar e do álcool, põem fim à fase áurea da intervenção governamental no setor.

A desregulamentação do setor atingiu profundamente a maioria das usinas de Pernambuco, considerando-se que sua viabilidade econômica vinha sendo garantida pelos subsídios, que contrabalançavam seus maiores custos. No início da década de 1990, havia 40 empresas que produziam álcool ou açúcar, e em 1999, contamse apenas 26. Portanto, desapareceram 2/3 desses empreendimentos. Dessas 26, apenas 5 possuem posição sólida no mercado (Belfort, 1999) ${ }^{12}$.

As usinas que sobreviviam apenas em função dos subsídios estão tendo de ganhar competitividade, para assegurar mercado. O caminho tem sido a modernização, que é bastante particular no que se refere à parte agrícola do empreendimento, pois depende das condições edafo-climáticas da microrregião. $\mathrm{Na}$ Mata Seca, por exemplo, o relevo favorece a mecanização, e o clima induz ao uso da irrigação. De uma maneira geral, têm-se abandonado as áreas de encostas, onde a cana tem um custo mais alto por causa da colheita e transporte. Prioritariamente, tem-se dado preferência às áreas de várzea, mais produtivas.

Observe-se que desde os anos 1930, Pernambuco abandonou o cultivo de variedades naturais; entretanto, essa mudança não se fez acompanhar por rápida modernização das técnicas culturais. Ou seja, a introdução de inovações biológicas não foi acompanhada de seu par, as inovações físico-químicas. Apesar da modernização mais rápida do segmento industrial, o declínio progressivo da produtividade natural da terra, acrescido dessa tecnificação bastante parcial do ciclo produtivo, passaram a afetar drasticamente o rendimento industrial. A desregulamentação da atividade põe fim às adaptações tecnológicas, subsidiadas indiretamente. Por outro lado, a diversificação de atividades, em nível empresarial, em razão da reestruturação do setor, tem sido lenta. Há

\footnotetext{
${ }^{12}$ Usinas: na MRH Mata Seca, Central Olho D’Água, São José e Petribứ; na MRH Mata Úmida, Ipojuca e Trapiche.
} 
uma mentalidade culturalmente herdada de que a região da Mata só se presta à cana-deaçủcar, e somente a cana poderá oferecer retorno econômico desejável.

\subsection{A Modernização na Mesorregião Agreste}

O Agreste Pemambucano compunha-se de quatro microrregiões homogêneas: Arcoverde, Agreste Setentrional, Agreste Meridional e Vale do Ipojuca ${ }^{13}$. Situa-se num raio de $200 \mathrm{~km}$ a oeste da mesorregião Mata Pernambucana. Segundo Melo (1962, p.521), ..."o Agreste, embora possuindo período seco bastante severo e, em certas áreas totais pluviométricos tão baixos quanto os de amplas extensões sertanejas, as terras agrestinas, situadas que estão em pleno domínio dos ventos do quadrante leste, não se incluem no vastíssimo território nordestino sujeito a longas estiagens de anos sucessivos. É fundamental esse fato na explicação dos fenômenos referentes ao uso agrícola da terra e ao povoamento na região. Graças a ele pode o Agreste possuir atividade agrícola mesmo nas áreas menos chuvosas e, em conseqüência, pode sustentar população várias vezes mais densas do que as terras sertanejas de igual pluviosidade”.

As transformações mais acentuadas da agropecuária agrestina ocorrem a partir dos anos 1950, devido à necessidade de quantidades crescentes de alimentos requeridos pelo mercado urbano em franca expansão: nesse período, estendem-se as áreas de pecuária, valorizando as terras produtivas, mas até então não utilizadas, e, na década seguinte, ocupando áreas de lavouras permanentes, através do plantio de pastagens. Dessa forma, a pecuária vai representar o primeiro movimento modernizante, enquanto a agricultura voltada à produção de alimentos básicos, pouco experimentaria de evolução tecnológica.

\footnotetext{
13 A partir do Censo de 1995/96, houve alteração do quadro microrregional estadual através da criação e desmembramento das antigas unidades geográfcas, passando a mesorregião Agreste a conter as seguintes microrregiões: Vale do Ipanema, Alto Capibaribe, Médio Capibaribe, Brejo Pernambucano, Garanhuns e Vale do. Ipojuca.
} 
A partir desse periodo, abre-se espaço, principalmente nas manchas férteis do Agreste, os brejos de altitude, para a introdução ou expansão de culturas de maior valor comercial. Ocorre um processo de substituição das culturas tradicionais, que são relegadas para áreas menos férteis, em favor de culturas intensivas em capital. Estas, apesar de apresentarem custo de produção mais oneroso, ofereceriam ao agricultor maior lucratividade.

Portanto, na década seguinte, prossegue a pecuarização substituindo culturas na caatinga, enquanto nos brejos, a hortifnuticultura passaria a representar outro vértice da modernização, também substituindo parcela das lavouras tradicionais, acarretando alteração na estrutura de distribuição do uso das terras.

Como aponta Medeiros (1970, p.28), com referência aos anos 1960, “a pecuária deixou de ser puramente extensiva e já é feita de maneira semi-extensiva em grande parte da região. Talvez em função dessa exploração racional dos rebanhos, é que os grandes e médios proprietários venham substituindo paulatinamente a agricultura pela pecuária, uma vez que esta tem assegurado melhores rendas quando da aplicação do capital. Mesmo em relação às lavouras, o algodão de modo especial, em vista da baixa produtividade e da inconstância dos preços, o que está acontecendo é a substituição por culturas de melhor rendimento econômico".

Além de Medeiros, Andrade (1982) e Redwood (1983) também analisaram a modernização da agricultura do Agreste, enquanto processo de reordenamento espacial de culturas, tanto dentro da fronteira do estabelecimento, quanto em termos de áreas especificas (caatinga e brejos). Isto é, o agricultor substitui parte das culturas tradicionais, as quais ficam relegadas apenas à sua subsistência, por culturas de maior valor comercial. Sob o prisma geográfico, essas lavouras, freqüentemente irrigadas, vão-se concentrar nos brejos, enquanto que às lavouras tradicionais, vão restar apenas as áreas mais secas, de caatinga.

Em resumo, o desenvolvimento desses novos produtos - hortaliças, flores e frutas - tem acarretado o quase confinamento das lavouras de alimentos básicos às áreas mais distantes das reservas hídricas. Mesmo nessas áreas, a tradicional policultura alimentar (feijão, milho e mandioca), juntamente com a cultura algodoeira, 
tem sido substituida por pastagens. Essa redefinição do uso da terra teria gerado ... "uma tendência para os pequenos produtores de culturas irrigadas a ficarem ilhados dentro de um sistema produtivo em que a pecuária também está em clara ascensão" (Redwood, 1983).

Ao mesmo tempo em que, no Agreste, ocorre um processo de modernização através da redefinição do uso da terra, tanto pela expansão da pecuária quanto dos novos produtos, exibiu-se, paralelamente, um movimento de deslocamento de algumas culturas modernas para a mesorregião Sertão, em especial, o tomate industrial e a cebola. Enquanto principal produtor de tomate, a região Agreste vai diminuindo progressivamente sua participação, a partir do início dos anos 1970. Dados para 1980, já mostravam o Sertão concentrando mais da metade da área cultivada. Na verdade, ocorreu um processo de especialização entre as duas mesorregiões, através do deslocamento do eixo principal de produção do tomate industrial para o Sertão, restando ao Agreste, o tomate de mesa.

Tabela 3.6. Distribuição percentual da área cultivada com tomate, cebola e alho, segundo mesorregiões de Pernambuco, 1949-80.

\begin{tabular}{|c|c|c|c|c|c|c|c|c|c|}
\hline \multirow{2}{*}{ Anos } & \multicolumn{3}{|c|}{ Tomate } & \multicolumn{3}{|c|}{ Cebola } & \multicolumn{3}{|c|}{ Alho } \\
\hline & Mata & Agreste & Sertão & Mata & Agreste & Sertão & Mata & Agreste & Sertão \\
\hline 1949 & 0,4 & 99,3 & 0,3 & 1,6 & 81,7 & 16,7 & - & 89,0 & 11,0 \\
\hline 1953 & 0,9 & 99,0 & 0,1 & 0,3 & 79,2 & 20,5 & - & 93,9 & 6,1 \\
\hline 1958 & 0,5 & 99,3 & 0,2 & - & 43,7 & 56,3 & - & 91,1 & 8,9 \\
\hline 1962 & 0,6 & 99,2 & 0,2 & - & 26,6 & 73,4 & - & 95,7 & 4,3 \\
\hline 1969 & 0,6 & 95,0 & 4,4 & - & 26,4 & 73,6 & - & 85,6 & 14,4 \\
\hline 1972 & 3,1 & 90,3 & 6,6 & - & 10,5 & 89,5 & - & 91,9 & 8,1 \\
\hline 1975 & 0,6 & 67,3 & 32,1 & - & 5,0 & 95,0 & - & 80,0 & 20,0 \\
\hline 1977 & 0,3 & 66,8 & 32,9 & - & - & 100,0 & - & 15,6 & 84,4 \\
\hline 1980 & 0,4 & 48,0 & 51,6 & $=$ & $=$ & 100,0 & $=$ & 22,3 & 77,7 \\
\hline
\end{tabular}

Dados bnutos: SERPE. Amuários Estatisticos de Permambuco, 1949/80. 
Também a lavoura da cebola estava concentrada inicialmente no Agreste. Porém, a partir dos anos 1950, exibe-se um processo tendencial de deslocamento da produção para a mesorregião Sertão, processo esse consumado no segundo quinquênio dos anos 1970 , quando a totalidade da área cultivada já estava concentrada nessa mesorregião.

\subsection{A Modernização na Mesorregião Sertão}

A mesorregião Sertão Pernambucano compunha-se de cinco microrregiões homogêneas: Alto Pajeú, Sertão do Moxotó, Araripina, Salgueiro e Sertão Pernambucano do São Francisco ${ }^{14}$. Situa-se a oeste da mesorregião Agreste Pernambucano. O Sertão possui totais pluviométricos baixos e se inclui no polígono das secas, dadas as longas estiagens de anos sucessivos. Ao contrário do Agreste, a população é menos densa. Predomina, grosso modo, o latifúndio voltado à pecuária extensiva. A base da agricultura é a policultura alimentar de subsistência.

A modernização agricola no Sertão teve como marco a introdução da cultura irrigada da cebola, nos anos 1950. Paulatinamente a expansão dessa cultura, em detrimento da produção no Agreste, redundou na completa mudança do padrão geográfico da lavoura. Nas décadas seguintes, foi ocorrendo um processo de diversificação agricola, incorporando-se às áreas irrigadas o tomate industrial e produtos da fruticultura: melão, melancia e uva.

Nos idos dos anos 1950, verificou-se um esforço pioneiro de organismos públicos no fomento à pequena irrigação na microrregião homogênea Sertão Pernambucano do São Francisco. Atuaram nessa época, através de Postos de Colonização e Assistência aos irrigantes, a Comissão do Vale do São Francisco (CVSF), a Secretaria de Agricultura do Estado, o Departamento Nacional de Obras contra as Secas (DNOCS), o Instituto Nacional de Irrigação e Colonização (INIC), o Ministério da Agricultura e o Bispado de Petrolina. Tais esforços, notadamente o da CVSF, provinham

\footnotetext{
${ }^{14}$ A partir do Censo de 1995/96, essa unidade geográfica foi desdobrada em duas microrregiões: Itaparica e Petrolina.
} 
de uma política de valonização regional do Vale do São Francisco, elaborada a partir da criação desse órgão em 1948. No segundo Govemo Vargas, são elaborados o Plano Geral do São Francisco e o $1^{\circ}$ Plano Qüinqüenal (1951-1955), que previam o fomento à pequena irrigação e a implantação de grandes sistemas de irrigação.

A atuação dos vários órgãos compreendia a expenimentação, difusão, assistência e financiamento de equipamentos de irrigação. Como resultado, ocorreu ... “a disseminação - por empréstimo ou pela venda - nas duas margens do rio, especialmente na margem esquerda e nas ilhas do São Francisco, de toda uma série de instalações individuais, basicamente as rodas d'água, os grupos de moto bombas e pequenas redes de canais" (CVSF, 1957). A conseqüência imediata da difusão da irrigação, foi a rápida expansão da cultura da cebola, deslocando seu eixo principal de produção do agreste para o sertão, transformando-se numa monocultura.

Os esforços da CVSF, entre o final dos anos 1950 e início dos anos 1960, na tentativa de diversificar o uso das terras irrigadas, não apresentaram grandes resultados, mesmo porque esse período inicial foi mais de experimentação agronômica de novas culturas. A diversificação processou-se mais significativamente a partir dos anos 70, através das lavouras do tomate, melão, melancia, uva e alho.

Um dos marcos do processo de diversificação foi a implantação, em 1962, pela SUDENE, em convênio com a FAO, do Projeto de Irrigação de Bebedouro, no município de Petrolina. Após a fase de experimentação, a partir de 1970 foi iniciado o assentamento de colonos. Seguiu-se a implantação de outros projetos públicos, dinamizando a irrigação e a diversificação agrícola e atraindo a iniciativa privada. Em outras microrregiões do Sertão, foi dinamizada a irrigação também através de projetos públicos irrigados, sob o controle do DNOCS.

Portanto, o processo de modernização agrícola visto sob o ângulo do desenvolvimento da irrigação, foi acelerado graças às ações do Govemo Federal, algumas envolvendo parcerias com organismos intemacionais: BID, Banco Mundial, FAO, etc. Os recursos foram orçamentados e transferidos através de programas específicos: Programa de Integração Nacional (PIN), Fundo de Desenvolvimento de Programas Integrados (FDPI), Programa Especial para o Desenvolvimento do Vale do 
São Francisco (PROVALE), Programa de Desenvolvimento de Áreas Integradas do Nordeste (POLONORDESTE), FINOR, FNE etc.

O incremento dos projetos irrigados atraiu para a região a implantação de indústrias de sementes. Segundo a CODEVASF (1983), em 1983 haviam sido plantados cerca de 600 hectares para a produção de sementes de hortaliças no Nordeste, destes, aproximadamente 450 hectares no Vale e o restante em projetos do DNOCS.

Desenvolveu-se também a agroindústria do tomate. Em 1972, praticamente não se cultivava tomate industrial sob irrigação em Pernambuco, enquanto que em 1982 a área estimada já era de 300 hectares. O parque industrial, acompanhando a expansão da cultura, foi substancialmente ampliado (Melo, 1983).

Em suma, a atuação governamental de fomento à irrigação, particularmente através da implantação de perimetros irrigados, a partir dos anos 70 , somada ao incremento de agroindústrias e cooperativas, foram os principais indutores da modernização nessa mesorregião, particularmente na microrregião homogênea Sertão Pernambucano do São Francisco.

Essa atuação governamental, além da implantação da estrutura fisica da irrigação e do crédito, sob modalidades diversas, englobou a pesquisa, assistência técnica e extensão rural, através de órgãos públicos e programas oficiais. Afora os perimetros do DNOCS e da CODEVASF, dinamizou-se a agricultura irrigada através da construção de açudes e barragens, possibilitando a expansão da hortifruticultura. Esse processo de modernização gerou um aumento da demanda de insumos agrícolas, máquinas e implementos. Em conseqüência, acarretou, a exemplo, o crescimento industrial no pólo Juazeiro-Petrolina. 


\section{ESTUDOS EMPÍRICOS SOBRE MODERNIZAÇÃO ATRAVÉS DA ANÁLISE FATORIAL}

Objetiva-se evidenciar neste capítulo os resultados de trabalhos relativos ao tema, enfatizando conclusões sobre a diferenciação tecnológica da estrutura de produção da agricultura pernambucana. Observe-se que não há nenhum trabalho ou capítulo específico sobre o Estado de Pernambuco. Nesse sentido, o intento aqui é o de reunir informações, inclusive aproveitando os dados para uma análise própria

O trabalho pioneiro de Mesquita et al. (1977) sobre modernização da agricultura brasileira produziu resultados importantes, dos quais pretende-se ressaltar partes da análise que tenham como referência Pernambuco. Aplicando a técnica de análise fatorial em 28 indicadores, extraídos do Censo Agropecuário de 1970, escolhidos para 359 microrregiões - as unidades de observação -, identificaram sete fatores ou dimensões de diferenciação da agricultura. Desse total, consideraram apenas cinco, que captaram $68,84 \%$ da variância dos indicadores, dos quais três se vincularam nitidamente à modernização da agricultura.

O primeiro fator (F1) foi interpretado como uma medida de modernização da agricultura com ênfase na lavoura. Nesta dimensão, foi identificada uma estrutura secundária de modernização referente à região Nordeste, caracterizada pelos indicadores relativos às despesas com sementes e mudas por hectare cultivado e pelo rendimento da terra expresso pelo valor das lavouras por hectare cultivado. "Acrescentam-se a esses indicadores o gasto com alimentação e trato com animais em 
microrregiões da mata pernambucana". Em Pernambuco, os valores mais altos de F1 foram encontrados para a Zona da Mata, região de predomínio da cana-de-açúcar, englobando três microrregiões homogêneas: Mata Seca, Mata Úmida e Recife. As demais microrregiões apresentam escassa modernização. No conjunto do Estado, os valores de F1 vão representando, no sentido leste-oeste, ou litoral-interior, níveis de modernização cada vez menores. Em suma, os níveis de modernização vão decrescendo da mesorregião da Mata, para a do Agreste, e desta para a mesorregião Sertão. Também subniveis de modernização poderiam ser identificados em cada mesorregião.

Um segundo fator identificado (F2), "modernização da agricultura com ênfase na pecuária", apresentou valores mais significativos também restritos à Zona da Mata de Pernambuco. A pecuária mais extensiva estaria predominantemente concentrada em microrregiões sertanejas.

Uma terceira dimensão (F3) expressou a mecanização da agricultura. Em Pernambuco, estaria restrita à Zona da Mata, principalmente às microrregiões Mata Seca e Recife. As demais microrregiões apresentaram escassa mecanização, principalmente as do Sertão.

Um quarto fator (F4) foi interpretado como medida de densidade de ocupação pela atividade agrária. Restringiu-se às microrregiões da Zona da Mata e do Agreste, principalmente a microrregião Agreste Setentrional. Opostamente, as microrregiões sertanejas, à exceção do Alto Pajeú, revelaram valores negativos, indicando baixa densidade de lavouras.

Um quinto fator (F5) caracterizou a dimensão indicativa da existência de um padrão elementar de modemização da agricultura. $O$ trabalho de Mesquita et al. (1977) não identificou, na primeira parte da análise, microrregiões características dessa dimensão em Pernambuco, considerando-se o contexto nacional. Observe-se que este fator explicou apenas $8,54 \%$ da variância dos dados originais, não sendo, portanto, de fácil entendimento.

Dada a constatação de ... "existência de vasta área, onde os elementos de modernização são ainda insuficientes para colocá-la acima da média nacional de modernização", Mesquita et al. (1977, p.27) passam a examiná-la, repetindo a análise 
fatorial em 28 indicadores, agora para apenas 257 unidades de observação: tratam-se, portanto, das microrregiões que não apresentaram uma modemização consistente. Nesse sentido, foram excluídas, nessa segunda parte da investigação, as microrregiões mais modernizadas de Pernambuco: Recife e Mata Seca. Essa análise explicou 70,18\% do total da variância original dos dados e apresentou sete fatores ou dimensões diferenciadoras, das quais quatro são as principais pela sua participação no total de explicação e pela sua composição indicativa de modernização. De uma maneira geral, essas dimensões, algumas vezes, são bastante polivalentes em seu significado, devendose ter cautela ao se analisá-las.

O Fator 1 foi interpretado como medida de modernização da agricultura com ênfase na pecuária. A microrregião Mata Úmida apresentou o mais expressivo escore. O Fator 2, modernização da agricultura com ênfase na lavoura, apresentou os indices mais expressivos, nas microrregiões Mata Úmida, Agreste Meridional e Agreste Setentrional. O terceiro Fator, F3, foi interpretado como medida de modemização da atividade agroleiteira. Destacaram-se a Mata Úmida e as microrregiões do Agreste, especialmente o Agreste Setentrional. À exceção do Alto Pajeú, todas as demais microrregiões do Sertão apresentam índices negativos. $\mathrm{O}$ quarto fator, modernização dos sistemas agrários, apresentou seus valores mais altos para a Mata Úmida e secundariamente para o Agreste Setentrional. Índices muito baixos foram registrados para o Sertão, à exceção do Sertão Pernambucano do São Francisco, provavelmente pela presença da agricultura irrigada. Com isto, essa microrregião se aproximou das microrregiões agrestinas Vale do Ipojuca e Agreste Meridional. Opostamente, a microrregião agrestina Arcoverde apresentou valor mais próximo dos muito baixos escores das demais microrregiões sertanejas, representando área de transição, entre Sertão e Agreste, ou entre o tecnologicamente tradicional e o medianamente tecnificado.

Como resultado final, considerando-se as duas análises fatoriais, pôde-se classificar o espaço agrário brasileiro em três áreas específicas: áreas modernizadas, áreas em integração ao processo de modernização; e áreas não integradas ao processo.

Especificamente em relação a Pernambuco, identificaram-se, no espaço modernizado, caracterizado por englobar microrregiões posicionadas acima da média 
nacional, as microrregiões Recife e Mata Seca. Essas duas unidades foram ainda classificadas num quarto nivel de modernização, considerando-se o território nacional. Segundo Mesquita et al. (1977, p.58) “a modernização dessas áreas caracteriza-se, fundamentalmente, pela existência de dois padrões: um, de caráter elementar, ligado ao uso da força animal, e outro, mais evoluído, individualizado pelo emprego da mecanização nos trabalhos agrários. Insumos modernos como fertilizantes, inseticidas, rações e medicamentos são também utilizados no processo de produção, embora não de maneira generalizada, havendo áreas caracterizadas mais pelo emprego de um ou outro desses insumos".

Situado dentro do espaço considerado em integração ao processo de modernização, segundo as análises de Mesquita et al. (1977, p.59), encontra-se o Agreste Setentrional, estando posicionado no segundo nível de integração, considerando-se o território nacional. Essa microrregião se individualizou pela produção agroleiteira. Num terceiro nível de integração, foram identificadas áreas de Pernambuco ... 'voltadas para a produção agropecuária e caracterizadas, em relação à modernização, pelos gastos com alimentação e trato dos animais e fertilizantes e, secundariamente, pelo uso da mecanização".

Pertencendo aos espaços não integrados ao processo de modemização, foram identificadas algumas microrregiões situadas na mesorregião Sertão: Araripina, Salgueiro, Sertão do Moxotó e Sertão Pernambucano do São Francisco. Com relação a essa última microrregião, provavelmente o peso excessivo de uma pecuária extensiva, juntamente com um sistema agrícola de sequeiro com técnicas bastante tradicionais, não tenha sido contrabalançado pela agricultura irrigada desenvolvida nas áreas ao longo do rio São Francisco. Além disso, em razão dos dados de 1970 terem sido inseridos no conjunto das microrregiões brasileiras, em uma única matriz, não pôde refletir o seu dinamismo, em termos de inserção de vasta área semi-árida ao processo de modernização.

Essa coexistência de um setor moderno com outro tradicional dentro de um mesmo espaço microrregional foi constatada por Troncoso Leone (1988, p.108), que realizou uma análise fatorial para a Bahia a partir de dados censitários de 1980. Com 
referência à microrregião baiana Corredeiras do São Francisco, limítrofe ao Sertão Pernambucano do São Francisco, tendo como divisor o próprio rio, considerou-a ... "muito heterogênea, destacando-se de um lado, uma lavoura intensiva, irrigada, de produtos de alto valor comercial, nas proximidades do Rio São Francisco, e de outro, uma pecuária extensiva de animais de grande e médio porte na caatinga. Na média, resultou um baixo valor para o Fator F1 (modemização)...”.

Algumas conclusões formuladas por Mesquita et al. (1977, p.62-63), para o contexto nacional ou das regiões Norte/Nordeste, contribuem na interpretação de dados para Pernambuco: 1. As áreas modemizadas freqüentemente correspondem às capitais de localização litorânea e os diferentes níveis de integração ao processo de modernização se dispõem do litoral para o interior, ou interligam, ao longo do litoral, os núcleos modernizados; 2. Existência de grandes espaços com áreas restritas modernizadas ou em processo de modernização e vastas áreas não integradas a esse processo; 3. Áreas contíguas apresentando níveis contrastantes de modemização, tanto dentro do espaço microrregional, quanto em espaços separados por limites estaduais, traduzindo-se na coexistência de um nível elementar com outro mais evoluído de modernização, resultante de disparidades verificadas em nível de produtores ou em nível de produtos.

Outro trabalho sobre modemização do qual se pode extrair dados para evidenciar o caráter diferenciado de distribuição do processo em Pernambuco, é o Zoneamento Agrário, realizado pelo convênio INCRASSERPRO (1978). Sua finalidade principal foi a de definir áreas prioritárias de reforma agrária. Foram utilizados dados do Cadastro de Imóveis Rurais de 1972, do INCRA, e dos Censos Agropecuário, Demográfico e Predial, de 1970, do IBGE.

Após um teste que envolveu 50 indicadores, considerando-se como unidades de observação todas as microrregiões do país, partiu-se para uma segunda fase, na qual foram selecionados e estratificados apenas 20 indicadores.

$\mathrm{Na}$ análise, extraíram-se duas componentes que explicaram $54,8 \%$ da variância total. A primeira componente principal apresentou quase todos os pesos (correlações) negativos. Dessa forma, “...regiões com baixos níveis de desenvolvimento 
terão notas (escores) muito positivas, nesta componente, e o oposto ocorrerá para regiões com alto nível de desenvolvimento. Esta componente, assim, é um indicador do nível geral de desenvolvimento".

“A segunda componente indicou o nível de concentração fundiária, descontado o nível de desenvolvimento (lembremos que as componentes principais são ortogonais e não-correlacionadas entre si); ou seja, dá-nos uma medida da concentração relativa ao grau de atraso".

Os escores das componentes para Pernambuco são apresentados na tabela 4.1. Observa-se que as microrregiões mais desenvolvidas, as que apresentam escores negativos, são Recife, Mata Seca e Agreste Setentrional. As demais microrregiões apresentam valores positivos, indicando regiões mais atrasadas que a média brasileira. Entretanto, valores medianos são apresentados pela Mata Úmida, Agreste Meridional, Vale do Ipojuca, Arcoverde, Alto Pajeú e Sertão Pernambucano do São Francisco. Restariam as microrregiões mais atrasadas, todas localizadas no Sertão: Araripina, Salgueiro e Sertão do Moxotó. Justamente unidades inseridas no vasto espaço não integrado à modernização, segundo Mesquita et al. (1977).

Os escores negativos relativos à segunda componente, apresentados por Recife e Mata Úmida estão indicando concentração fundiária maior do que a média. Juntamente com a Mata Seca, essas três microrregiões formam uma área contínua. Conclui-se que justamente na faixa geográfica ocupada pela atividade mais modernizada no Estado - o setor sucroalcooleiro - o desenvolvimento ocorre com concentração fundiária, indicando uma acumulação capitalista no campo baseada na grande propriedade. Opostamente, no Agreste, principalmente o Setentrional, ocorreria desenvolvimento com relativa desconcentração fundiária. No Sertão, para as microrregiões Salgueiro e Moxotó, os dados claramente revelam associação positiva entre atraso e concentração. 
Tabela 4.1. Valores das componentes principais, segundo microrregiões homogêneas, na análise fatorial em 20 indicadores estratificados. Pernambuco, 1970-72.

\begin{tabular}{|c|c|c|}
\hline Microrregião & $\begin{array}{l}\text { Componente principal } 1 \\
\text { "Desenvolvimento" }\end{array}$ & $\begin{array}{l}\text { Componente principal } 2 \\
\text { "Concentração fundiária" }\end{array}$ \\
\hline Recife & $-0,36$ & $-1,13$ \\
\hline Mata Seca & $-0,34$ & 0,01 \\
\hline Mata Úmida & 0,12 & $-0,41$ \\
\hline Arcoverde & 0,43 & 0,82 \\
\hline Agreste Setentrional & $-0,08$ & 1,90 \\
\hline Agreste Meridional & 0,09 & 1,61 \\
\hline Vale do Ipojuca & 0,13 & 1,33 \\
\hline Araripina & 0,91 & 1,51 \\
\hline Salgueiro & 0,78 & 0,68 \\
\hline $\begin{array}{l}\text { Sertão Pernambucano do } \\
\text { São Francisco }\end{array}$ & 0,48 & 0,78 \\
\hline Sertão do Moxotó & 0,74 & 0,40 \\
\hline Alto Pajeú & 0,36 & 1,38 \\
\hline
\end{tabular}

Fonte: Tabela elaborada a partir de dados do apêndice de INCRA/SERPRO (1978).

"Embora elucidativa, a rotação Varimax tem um aspecto desconfortável: não existe nenhuma base para se postular independência entre níveis de desenvolvimento e de concentração fundiária; na verdade, existem muitas razões para se supor exatamente o contrário" (INCRA/SERPRO, 1978, p.63). Em razão disso, foi feita uma rotação Oblimin das duas primeiras componentes principais, resultando em dois fatores oblíquos. $\mathrm{O}$ primeiro fator apresentou regiões desenvolvidas com notas negativas. Para o segundo fator, valores negativos significam concentração fundiária maior do que a média (Tabela 4.2). 
Tabela 4.2. Valores de dois fatores principais obliquos, segundo microrregiões homogêneas, na análise fatorial em 20 indicadores estratificados. Pernambuco, 1970-72.

\begin{tabular}{|c|c|c|}
\hline Microrregião & Fator 1 (desenvolvimento) & $\begin{array}{c}\text { Fator } 2 \\
\text { (concentração fundiária) }\end{array}$ \\
\hline Recife & $-0,66$ & $-0,69$ \\
\hline Mata Seca & $-0,32$ & 0,21 \\
\hline Mata Úmida & 0,00 & $-0,40$ \\
\hline Arcoverde & 0,64 & 0,40 \\
\hline Agreste Setentrional & 0,45 & 1,58 \\
\hline Agreste Meridional & 0,54 & 1,24 \\
\hline Vale do Ipojuca & 0,50 & 1,00 \\
\hline Araripina & 1,30 & 0,67 \\
\hline Salgueiro & 0,94 & 0,08 \\
\hline $\begin{array}{l}\text { Sertão Pernambucano do } \\
\text { São Francisco }\end{array}$ & 0,68 & 0,35 \\
\hline Sertão do Moxotó & 0,82 & $-0,12$ \\
\hline Alto Pajeú & 0,73 & 0,90 \\
\hline
\end{tabular}

Fonte: Tabela elaborada a partir de dados do apêndice de INCRA/SERPRO (1978).

As microrregiões com escores negativos (mais modernizadas que a média) são as do Recife e Mata Seca. Em relação ao Fator 2, identificaram-se três microrregiões com escores negativos (concentração fundiária maior que a média): Recife, Mata Úmida e Sertão do Moxotó.

Segundo o trabalho do INCRA/SERPRO (1977, p.63), “analisando a correlação entre fatores, diremos que o desenvolvimento está negativamente associado à concentração fundiária, tomando como universo as microrregiões do Brasil". Entretanto, os valores dos fatores para Pernambuco estão evidenciando tanto uma associação 
positiva, a exemplo das microrregiões da Zona da Mata, quanto uma associação negativa, a exemplo do Sertão do Moxotó.

Objetivando-se identificar o melhor possivel os fatores contidos nos dados, os autores realizaram uma análise de imagem. "A técnica baseia-se na construção de uma matriz de covariâncias-imagem (covariância das regressões de cada indicador normalizado sobre os demais), da qual se extraem os valores e vetores próprios de modo análogo à extração das componentes principais da matriz de correlação". Em seguida, fez-se uma rotação Varimax (Tabela 4.3).

Tabela 4.3. Valores de três fatores imagem, segundo microrregiões homogêneas, na análise fatorial em 20 indicadores estratificados. Pernambuco, 1970-72.

\begin{tabular}{lccc}
\hline \multicolumn{1}{c}{ Microrregião } & $\begin{array}{c}\text { Fator 1 } \\
\text { (concentração fundiária) }\end{array}$ & $\begin{array}{c}\text { Fator 2 } \\
\text { (mecanização) }\end{array}$ & $\begin{array}{c}\text { Fator 3 } \\
\text { (valorização) }\end{array}$ \\
\hline Recife & 0,46 & $-1,58$ & 2,61 \\
Mata Seca & 0,83 & $-1,80$ & 1,14 \\
Mata Úmida & 0,00 & $-1,55$ & 1,03 \\
\hline Arcoverde & 0,39 & $-0,55$ & $-0,80$ \\
Agreste Setentrional & 1,99 & $-1,72$ & $-0,28$ \\
Agreste Meridional & 1,69 & $-0,91$ & $-0,65$ \\
Vale do Ipojuca & 1,50 & $-0,97$ & $-0,43$ \\
\hline Araripina & 0,55 & $-0,98$ & $-1,18$ \\
Salgueiro & $-0,22$ & $-0,74$ & $-0,69$ \\
Sertão Pernambucano do São & 0,32 & $-0,10$ & $-0,64$ \\
Francisco & $-0,22$ & $-0,23$ & $-1,16$ \\
Sertão do Moxotó & 0,92 & $-0,51$ & $-1,14$ \\
Alto Pajeú & & & \\
\hline \hline
\end{tabular}

Fonte: Tabela elaborada a partir de dados do apéndice de INCRA/SERPRO (1978).

“O primeiro fator é um velho conhecido: latifúndio associado à pouca valorização das terras; já o segundo, é um claro fator de mecanização e produtividade, e o terceiro, é um fator de valorização e de boas condições de vida" (INCRA/SERPRO, 1978, p.68). 
Valores negativos para o Fator 1 significam concentração fundiária maior que a média e para o Fator 2 , menor mecanização que a média.

Valores negativos para o Fator 1 ocorreram apenas para as microrregiões sertanejas Salgueiro e Sertão do Moxotó, indicando alta concentração fundiária. Por outro lado, todas as microrregiões apresentaram mecanização menor que a média, vista pelos valores negativos. No aspecto valorização, vista pela leitura dos escores de F3, assumem destaque as microrregiões da Zona da Mata: Recife, Mata Seca e Mata Úmida.

De um modo geral, afora as especificidades microrregionais, observa-se que, na região canavieira, a valorização das terras associou-se positivamente à concentração fundiária e negativamente à baixa mecanização; no Agreste, ocorreu menos intensa concentração fundiária ao lado de escassa mecanização e pequena valorização das terras; no Sertão, concentração fundiária e menor valorização das terras.

Em seguida, "retendo cinco componentes principais, foi feita uma rotação Oblimin. A finalidade aqui era, relaxando a exigência de não correlacionamento, identificar fatores mais ou menos "naturais" aos dados" (Tabela 4.4).

Tabela 4.4. Valores de cinco fatores principais oblíquos, segundo microrregiões homogêneas, na análise fatorial em 20 indicadores estratificados. Pernambuco, 1970-72.

\begin{tabular}{|c|c|c|c|c|c|}
\hline Microrregião & Fator 1 * & Fator $2^{\star *}$ & Fator 3*** & 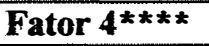 & Fator $5^{\star \star \star \star \star \star}$ \\
\hline Recife & $-0,68$ & $-3,22$ & $-1,82$ & 0,44 & -0.12 \\
\hline Mata Seca & 0,53 & $-2,26$ & $-1,87$ & $-0,29$ & $-1,28$ \\
\hline Mata Úmida & 0,70 & $-2,27$ & $-1,16$ & -0.11 & -0.72 \\
\hline Arcoverde & 0.82 & 0,53 & $-0,24$ & 0.05 & 0.24 \\
\hline Agreste Setentrional & 1,21 & $-0,01$ & $-2,20$ & $-0,37$ & $-0,47$ \\
\hline Agreste Meridional & 0,78 & 0,56 & $-1,53$ & $-0,25$ & 0,71 \\
\hline Vale do Ipojuca & 0,61 & 0,43 & $-1,30$ & $-0,03$ & 0,60 \\
\hline Araripina & 1,37 & 0,88 & $-0,46$ & 0,94 & $-0,23$ \\
\hline Salgueiro & 1,08 & 0,40 & 0,08 & 0,51 & -0.05 \\
\hline $\begin{array}{l}\text { Sertão Pemambucano } \\
\text { do São Francisco }\end{array}$ & 0,34 & 0,78 & $-0,08$ & 0,98 & -0.09 \\
\hline Sertão do Moxotó & 0,87 & 0,65 & 0,54 & 0,18 & 0,50 \\
\hline Alto Pajeú & 1,00 & 0,70 & $-0,74$ & 0,30 & $-0,42$ \\
\hline
\end{tabular}

Fonte: Tabela elaborada a partir de dados do apêndice de INCRASSERPRO (1978).

* valorização, mecanização e boas condiçōes de vida; ** pequena propriedade tradicional; *** latifúndio, pouca valorização dos imóveis, rarefação demográfica; **** aproveitamento das terras, mecanização e capitalização; ***** produtividade e comercialização. 
O Fator 1 (valorização, mecanização e boas condições de vida) teve destaque na microrregião Recife; o Fator 2 (pequena propriedade tradicional) mostrou, claramente, microrregiões agrestinas e sertanejas nas quais prevaleceria esse tipo de exploração, contrapondo-se à propriedade mais tecnificada (microrregiões da Mata e Agreste Setentrional); identicamente, o Fator 3 (latifúndio, pouca valorização dos imóveis, rarefação demográfica) contrapôs microrregiões com alta valorização dos imóveis e maior densidade populacional - as microrregiões da Mata e do Agreste, à exceção de Arcoverde - às microrregiões sertanejas. Para o Fator 4 (aproveitamento das terras, mecanização e capitalização), sobressairam-se a Mata Seca, a Mata Úmida e a mesorregião Agreste, à exceção de Arcoverde. Já o Fator 5 (produtividade e comercialização), correlacionado negativamente ao uso de força humana e à aplicação de fertilizantes, é de dificil interpretação. Contudo, uma leitura exploratória dos escores indicou a existência de melhor produtividade na Mata Seca, microrregião mais representativa, em oposição ao Sertão do Moxotó, microrregião pior posicionada em termos de produtividade no Sertão.

A análise fatorial realizada por Hoffmann \& Kassouf (1989), para 158 microrregiões homogêneas utilizando dados do Censo Agropecuário de 1980, também produziu resultados importantes na avaliação da diferenciação tecnológica entre os espaços microrregionais. Foram obtidos cinco fatores, mas considerados apenas três, que, em conjunto, captaram $74 \%$ da variância total das 31 variáveis tomadas para o estudo. Os resultados para Pernambuco foram reordenados na Tabela 4.5.

Os autores constataram, em linhas gerais, valores negativos para os três fatores, mostrando o baixo grau de modemização vigente no estado. Entretanto, destacaram os valores positivos de FI (intensidade de exploração da terra) para as microrregiões homogêneas da Zona da Mata. Para as demais, os escores são negativos. Por outro lado, observe-se que, no Agreste, das quatro microrregiões, apenas uma (Arcoverde) apresentou escore inferior a $-0,6$, enquanto, no Sertão, foram quatro microrregiões, restando, como exceção, o Sertão Pernambucano do São Francisco (0,39). Em conclusão, os indices microrregionais revelam que a mesorregião Sertão 
encontrava-se pior posicionada, comparativamente a do Agreste, no que se refere à intensidade de exploração da terra.

Tabela 4.5. Valores de três fatores de modernização segundo microrregiões de Pernambuco, 1980.

\begin{tabular}{|c|c|c|c|}
\hline Microrregião & Fator $1^{*}$ & Fator 2** & Fator $3^{\star \star \star \star}$ \\
\hline Recife & 2,37 & $-1,54$ & $-1,74$ \\
\hline Mata Seca & 2,30 & $-1,33$ & $-1,61$ \\
\hline Mata Úmida & 1,18 & $-1,34$ & $-1,85$ \\
\hline Arcoverde & $-0,69$ & $-0,80$ & 0,12 \\
\hline Agreste Setentrional & $-0,05$ & $-1,14$ & $-0,21$ \\
\hline Agreste Meridional & $-0,36$ & $-0,78$ & 0,18 \\
\hline Vale do Ipojuca & $-0,27$ & $-1,04$ & $-0,21$ \\
\hline Araripina & $-0,73$ & $-0,82$ & $-0,62$ \\
\hline Salgueiro & $-0,77$ & $-0,72$ & $-0,70$ \\
\hline $\begin{array}{l}\text { Sertão Pernambucano do São } \\
\text { Francisco }\end{array}$ & $-0,39$ & $-0,64$ & $-1,05$ \\
\hline Sertão do Moxotó & $-0,81$ & $-0,87$ & $-0,28$ \\
\hline Alto Pajeú & $-0,62$ & $-0,83$ & $-0,04$ \\
\hline
\end{tabular}

Fonte: Tabela elaborada a partir de dados de Hoffinann e Kassouf (1989).

* intensidade de exploração da terra; ${ }^{* *}$ produtividade do trabalho; ${ }^{* * *}$ produção familiar com uso de tração animal.

Os valores negativos de F2 para todas as microrregiões estão indicando baixa produtividade do trabalho. Já os valores positivos de $\mathrm{F} 3$ indicam que a produção familiar com uso de tração animal está concentrada nas microrregiões Arcoverde e Agreste Meridional. Observe-se que os valores de F3 para as microrregiões da Zona da Mata e o Sertão do São Francisco, são inferiores a -1,00, indicando forte distanciamento em relação à estrutura representativa da "produção familiar com uso de tração animal".

Hoffmann (1992) realizou uma análise dinâmica da modernização da agricultura em 157 microrregiões homogêneas do Brasil. Com a finalidade de se obter 
uma medida de velocidade do processo de modernização em cada unidade de observação, foi feita uma análise fatorial agregando-se as observações para os anos de 1975 e 1980, tomando um conjunto de 31 indicadores extraídos dos Censos. Selecionaram-se dois fatores que responderam por $60,8 \%$ da variância total: F1 (intensidade de exploração da terra) e F2 (relação capital/trabalho).

A análise dos escores dos fatores relativos à cada unidade geográfica de Pernambuco permitiu constatar ... "o relativo atraso do processo de modernização da agricultura na maioria das microrregiões, com valores negativos tanto para F1 como para F2, mesmo em 1980. As microrregiões da Zona da Mata (Mata Seca Pernambucana, Recife e Mata Úmida Pernambucana) destacaram-se pela intensidade de exploração da terra, mas apenas as duas primeiras microrregiões apresentaram valor positivo em 1980". O autor identificou, também, a ocorrência de um processo de modemização intenso, entre 1975 e 1980, com referência às microrregiões Recife e ... "Sertão Pernambucano do São Francisco, onde está localizada parte do pólo de irrigação conhecido por Dipólo Petrolina - Juazeiro..." (Hoffinann, 1992, p.286).

Analisando-se os valores dos fatores, para Pernambuco, obtidos por Hoffmann (1992), constatou-se que os escores negativos dos Fatores 1 e 2 das microrregiões do Sertão são, predominantemente, inferiores aos do Agreste, que por sua vez, são relativamente inferiores aos das microrregiões da Mata. Em outras palavras, esses índices levaram a concluir que a modernização perderia intensidade no sentido litoral-interior, ou, Mata - Agreste - Sertão, em 1975 e 1980. Verificou-se, também, o aumento generalizado, mas diferenciado, dos escores microrregionais de F1 e de F2, entre 1975 e 1980. Conquanto exista essa tendência, a modernização continua concentrada na Zona da Mata. Em outras microrregiões, como as do Agreste, a modernização revela-se diferenciada, mais ambivalente; no Sertão, continua relativamente restrita às manchas ou bolsões, a exemplo das áreas irrigadas do Sertão do São Francisco, contrapondo-se às vastas áreas da própria microrregião, nas quais predominam a policultura alimentar tradicional e a pecuária extensiva. 


\section{METODOLOGIA}

\subsection{Análise fatorial}

Pretende-se utilizar a análise fatorial com vistas a identificar a natureza do processo de modernização agricola. A razão da escolha prende-se ao fato de que a investigação desse processo envolve um grande conjunto de variáveis. Em função disso, a utilização de uma técnica de análise multivariada de dados torna-se oportuna porque vai permitir representar o fenômeno da modenização através de pequeno número de indicadores compostos (variáveis sintéticas ou fatores estimados), aos quais se pretenderá atribuir um significado.

Em outras palavras, a análise fatorial vai permitir resumir a enorme quantidade de indicadores. Em se tratando da análise fatorial dinâmica, vai facilitar também comparações intertemporais entre cada variável, agora os denominados fatores, e entre as microrregiões, através dos valores dos fatores ou escores para cada uma dessas unidades de observação.

De posse dos principais fatores, normalmente de dois a três, vai-se verificar a quais variáveis determinado fator está mais associado e que interpretação pode-se dar a esse subconjunto ou estrutura, de modo que se possa expressar o que o fator está medindo. 
As unidades de observação ou análise são principalmente as microrregiōes homogêneas (MRHs) ${ }^{15}$, compreendendo cinco cortes temporais: 1950, 1960, 1970, 1980 e 1996. Para os dados de 1950 até 1980, far-se-á uma análise fatorial dinâmica. Objetiva-se analisar o grau e a natureza do processo de modemização em cada unidade geográfica e a velocidade do processo em periodos intercensitários. Para os dados do último Censo, o de 1995/96, pretende-se efetuar uma análise estática, cujo escopo é o de, uma vez delineado o processo, obter uma caracterização atual e abrangente da modemização no estado, com maior riqueza de indicadores, não permitida na análise anterior, tendo em vista as restrições de comparabilidade entre cada Censo.

Um dos primeiros trabalhos sobre agricultura brasileira que utilizou a análise fatorial foi elaborado no âmbito do Convênio INCRA/SERPRO, iniciado em 1975 e publicado em 1978. Seu principal objetivo foi o de realizar um zoneamento agrário do País com o fim de delimitar as áreas prioritárias de reforma agrária. Trata-se do único trabalho a empregar simultaneamente dados do INCRA e do IBGE, apesar do problema da comparabilidade das informações, pois, como é sabido, suas unidades pesquisadas são diferentes: imóveis rurais x estabelecimentos. Quase como uma exceção à maioria dos trabalhos, utilizou, além da rotação varimax, outro tipo de rotação que, ao contrário da anterior, não pressupõe a ortogonalidade dos fatores: a rotação oblimin.

Também no final da década dos anos 1970, tem-se o trabalho de Castanheira (1976), o de geógrafos do IBGE (Mesquita et al., 1977), sobre modemização da agricultura brasileira, e a tese de Ph.D. de Cunha (1978), sobre esse tema acrescido da questão relativa à pobreza nural.

O tema modernização e suas implicações sobre distribuição de renda, pobreza rural e estrutura fundiária, utilizando-se a análise fatorial, vai definindo uma linha de trabalho, cujos resultados têm aparecido principalmente em dissertações e teses, pesquisas, e artigos em revistas especializadas, que entre outros, citam-se: Carvalho (1982), Lanillo (1984), Hoffmann \& Kageyama (1985), Hoffmann \& Kassouf (1989),

\footnotetext{
${ }^{15}$ Para 1950, 1960, 1970 e 1980, trabalhou-se com 12 microregiões homogêneas, enquanto que, para 1995/96, foram investigadas 13 microrregiões e duas mesorregiões, em função das alterações promovidas pelo IBGE.
} 
Hoffmann (1992), Troncoso Leone (1988), Andrade (1989), Tarsitano (1990), Zanchet (1990), Guedes (1992), Figueiredo (1996), Espírito Santo (1988).

Para efetuar a análise fatorial, há vários métodos: máxima verossimilhança, fatores principais e o dos componentes principais. Na análise fatorial dos indicadores de modernização considerados nesta Tese, optou-se pelo terceiro, por sua simplicidade. $\mathrm{O}$ método dos componentes principais parte da matriz das correlações simples a partir da qual são extraídos os fatores comuns ou componentes principais. As etapas dessa técnica estatística serão expostas a seguir.

Parte-se do conjunto de dados secundários do IBGE, que corresponderão às $(l)$ observações (as microrregiões homogêneas), para determinada quantidade (n) de variáveis, resultando na matriz $\mathrm{X}\left(\mathrm{n}_{\mathrm{x}} \mathrm{l}\right)$, cujos valores serão transformados de modo que tenham a mesma variância e a sua participação na determinação dos componentes principais irá, então, depender apenas das suas correlações com as demais variáveis.

A partir dessa transformação, a etapa seguinte será a de obter a matriz $\mathrm{R}=\mathrm{XX}$ ' das correlações simples $(\boldsymbol{n} \times \boldsymbol{n})$, ou seja, a matriz das correlações entre cada uma das $n$ variáveis.

Da matriz das correlações simples, através do método dos componentes principais, serão obtidas as raizes características. À cada raiz ou autovalor (eigenvalue) está associado um componente principal ou fator. Os componentes principais são combinações lineares de variáveis, sendo o primeiro, o que está associado à maior raiz característica, e o que apresenta variância máxima, ou seja, é o que explica ou capta a maior proporção da variância dos dados originais. As raizes são ordenadas em ordem decrescente, e, em conseqüência, também os componentes principais, já que estão associados a cada uma das raizes. Então, o segundo componente, o que está associado à segunda maior raiz característica, é a combinação linear que apresenta a segunda variância máxima, e, assim, sucessivamente, até a última raiz característica.

$O$ passo seguinte é o de obter a matriz $A$, também conhecida como estrutura dos fatores. Isto é, a matriz das cargas fatoriais (factor loadings) ou dos 
coeficientes de correlação entre cada uma das $\boldsymbol{n}$ variáveis e cada fator obtido. Cada fator vai explicar uma parcela da variância do conjunto de dados. Como estão ordenados em ordem decrescente, o primeiro fator é o que vai explicar a maior proporção da variância dos dados, e assim sucessivamente. Apesar das variáveis originais serem correlacionadas, as novas variáveis obtidas, os fatores, são ortogonais entre si.

A soma dos quadrados dos elementos de cada coluna da matriz $\mathrm{A}$, ou seja, a soma dos quadrados das correlações de determinado fator com cada uma das $n$ variáveis, corresponde à respectiva raiz característica. Dividindo-se esse valor pelo total de variáveis, obtém-se a parcela da variância explicada pelo fator. Por outro lado, a soma dos quadrados dos elementos de qualquer linha, isto é, das correlações de uma variável com cada um dos fatores, é igual à unidade. Então, todos os fatores em conjunto estarão explicando $100 \%$ da variância de cada uma das variáveis.

Normalmente, na análise fatorial extraem-se apenas os fatores associados a raizes características maiores que um. Mas, além desse critério, dependendo do total obtido, retém-se apenas de 2 a 3 fatores de modo a simplificar e facilitar a análise. Ao se considerar um número inferior de fatores em relação ao total existente, haverá perda de informação. Em conseqüência, o total da variância explicada pelo conjunto de fatores selecionados, isto é a comunalidade, deverá ser inferior aos $100 \%$. Quanto mais próximo de um, o valor da comunalidade, maior parte da variância da variável estará sendo captada pelo conjunto de fatores considerados.

Após a obtenção das raizes características e da matriz das cargas fatoriais, é recomendável fazer-se a rotação dos fatores, mantendo a ortogonalidade entre os mesmos. A rotação vai fornecer uma nova matriz dos coeficientes e propiciar que o valor absoluto de cada variável, isto é, o coeficiente de correlação do fator com cada variável, aproxime-se de zero ou 1 . Ou seja, cada um dos novos fatores deverá apresentar correlação relativamente forte ou fraca, segundo conjuntos especificos de variáveis, facilitando a interpretação do significado dos fatores. Será utilizado o método de rotação Varimax. 
A rotação não vai alterar as comunalidades. Em outras palavras, a proporção da variância explicada pelo conjunto de fatores, ou por cada fator, em relação a cada variável, continuará a mesma. Entretanto, a proporção da variância atribuível a cada fator será modificada.

Em seguida, deve-se obter a matriz $\mathrm{F}$, que contém os valores de cada fator para cada microrregião. Esses valores são também chamados de escores ou índices, constituindo-se, exatamente, as projeções normalizadas dos pontos representativos das microrregiões sobre os eixos dos fatores. Por construção, têm média zero e desvio padrão unitário (INCRA/SERPRO, 1978, p.54). Os escores fatoriais fornecerão os níveis de modernização, podendo-se, opcionalmente, realizar uma estratificação em que se desenhem as zonas diferenciais características do processo.

O processamento dos dados, referente à análise fatorial através do método dos componentes principais, foi efetuado utilizando os recursos disponíveis no pacote computacional do SAS (Statistical Analysis System)*.

\subsection{Dados estatísticos}

As fontes utilizadas são os Censos do IBGE, dos quais foram extraídos os dados referentes às variáveis de interesse, visando-se obter os indicadores de modemização, trabalhados, posteriormente, através da análise fatorial.

O inteiro periodo de abrangência da investigação vai de 1950 a 1996. Considerou-se um espaço de tempo relativamente longo, para que o processo de modernização em seus desdobramentos fosse adequadamente captado. Além disso, a literatura e os dados estatísticos indicam ser a partir dos anos 1950 o início do processo. Com isso, estarão presentes os efeitos das políticas do final da era Vargas (1951/54) e do período desenvolvimentista do Governo JK (1956/61). Nesse sentido, este estudo apresenta a singularidade, em relação a outros trabalhos envolvendo a análise fatorial de

\footnotetext{
" SAS é marca registrada do SAS Institute Inc. Cary, NC.
} 
processos de modernização, ao tomar períodos anteriores a 1970 , tendo por base de observação as microrregiões homogêneas.

Ao se considerar os Censos anteriores ao de 1970 e o posterior ao de 1985, especificamente os Censos Agrícolas de 1950 e 1960 e o Censo Agropecuário de 1995/96, existirão alguns problemas relativos à comparabilidade. A primeira restrição diz respeito às unidades geográficas intermediárias entre o município e o estado, ou entre municipio e mesorregião. Os Censos de 1950 e de 1960 trabalham com as unidades "zonas fisiográficas" que, além de diferirem das atuais microrregiões homogêneas, por outro lado, não são exatamente as mesmas entre os dois Censos: a partir do Censo de 1960, promoveu-se uma maior desagregação das zonas fisiográficas, especialmente as localizadas no Sertão.

Já os Censos de 1970, 1980, 1985 e de 1995/96 tomam como unidade intermediária, as microrregiões homogêneas. Entretanto, contrariamente aos demais, para o Censo de 1995/96 houve modificação: promoveu-se o desmembramento de vários espaços microrregionais, bem como da mesorregião Sertão. Em conseqüência, o número de microrregiões saltou de 12 para um total de 20. Essa alteração acarretou a perda de comparabilidade entre o último Censo e os de 1970, 80 e 85

Nesta Tese, coletaram-se os dados estatísticos, no caso específico da análise dinâmica, tendo-se como base o conjunto de microrregiões homogêneas consideradas pelos Censos de 1970 a 1980. Essa escolha se justificou por dois motivos: o primeiro, pelo fato de que a maior parte dos Censos ter seus dados apresentados nesta regionalização; em segundo, em face de toda literatura que referencia as suas análises às microrregiões anteriores e não às atuais. Em sendo assim, dados estatísticos, análises e conclusões dessa bibliografia puderam servir de fundamento, dada a existência de comparabilidade entre as unidades de observação adotadas.

Com vistas a tornar operacionalizável a utilização dos Censos de 1950 e 60, considerando-se um trabalho comparativo para o periodo 1950/1980, foi feita, primeiramente, a reagregação dos dados selecionados das antigas "zonas fisiográficas", município a município, recompondo-os nas microrregiões dos Censos do período 
1970/1980. A tabela 5.1 apresenta a equivalência dessas microrregiões em termos das unidades geográficas adotadas nos Censos anteriores ao de 1970.

Tabela 5.1. Equivalência aproximada entre microrregiões homogêneas (Censos de 1970 ao de 1985) e zonas fisiográficas (Censos de 1950 e 1960) para o Estado de Pernambuco.

\begin{tabular}{|c|c|c|c|}
\hline CaNSODE 1950 & OTNSODFIOGO & 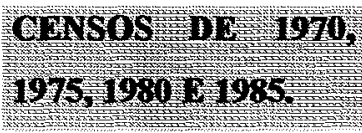 & 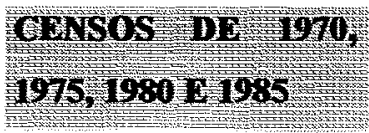 \\
\hline Zonas Fisiográficas & Zonas Fisiográficas & $\begin{array}{l}\text { Microrregiōes } \\
\text { Homogêneas }\end{array}$ & Mesorregiōes \\
\hline Zona do Sertáo Baixo & 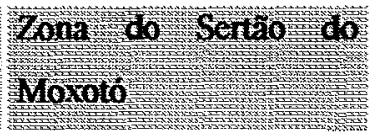 & Arooxerde, & AgratePeruambueano \\
\hline Zona do Sertão Baixo & $\begin{array}{l}\text { Zona do Sertão ou do } \\
\text { Alto Moxotó }\end{array}$ & do Moxotó & Sertão Pemambucano \\
\hline Zona do Sertáo Alio & Triunfo: & Alto Pajed & Serforo Perambicano \\
\hline Zona do Sertão Alto & $\begin{array}{l}\text { Zona do Sertão Alto ou } \\
\text { do Alto Pajeú }\end{array}$ & Alto Pajeú & mambucano \\
\hline Zona do Sertão do Araripo & Zona do Araripe & Araripe & Sertáo Perrambucano \\
\hline Zona do Sertão do Araripe & Zona do Sertão Central & Salgueiro & Sertão Penambarano \\
\hline $\begin{array}{l}\text { Zona do Sertâo do sáo } \\
\text { Francisco }\end{array}$ & 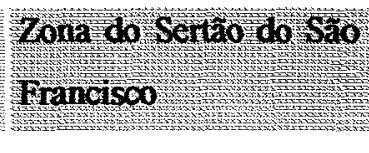 & 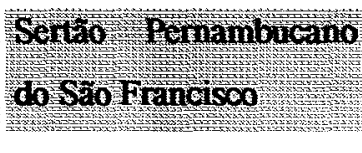 & Sertá Pernambicano \\
\hline Zona do Litoral e Mata & Zona do Litoral e Má & Redife & Rocife \\
\hline e Mata & o Litoral e Mata & Seca & ernambucana \\
\hline Zona do L itoral e Mata & Rona do S fitoral e Nata & Mata Umida & Mata fernambucana \\
\hline Zona do Agreste & Zona do Apreste & Arookerde & Agresto Pernambiarino \\
\hline Zona do Agrese & Agreste & e Setentrional & e Pernambucano \\
\hline Zona do Agreste & Zona do Agreste & Agreste Meriolonal & Agreste Pemambucano \\
\hline Zona do Agreste & Zona do Agreste & Vale do Ipojuca & Agreste Pemambucano \\
\hline
\end{tabular}


Com referência ao Censo Agropecuário de 1995/1996, os dados foram mantidos no quadro microrregional onde estão inseridos. Em não havendo comparabilidade direta e feita a opção de não recomposição dos dados para o antigo ordenamento microrregional dos municípios, descartou-se a sua inclusão na análise fatorial dinâmica: preferiu-se utilizá-los em análise individualizada, isto é, na análise fatorial estática.

Como resultado, os escores fatoriais para 1995/96 não puderam ser comparados diretamente com os escores para os cortes temporais 1950, 1960, 1970 e 1980, em face de ambos conjuntos de dados terem sido submetidos a análises próprias resultando em fatores distintos-, e por terem como referência quadro microrregional diverso. Entretanto, pôde-se fazer algumas inferências das posições relativas das novas microrregiões em relação às anteriores, pois a reestruturação microrregional, efetuada pelo IBGE, preservou uma relativa identidade com referência às microrregiões adotadas nos Censos anteriores. Nesse sentido, apresenta-se na tabela 5.2 a equivalência ${ }^{16}$ aproximada entre as microrregiões dos Censos do período 1970/1985 e as do Censo de $1995 / 1996$.

No último Censo, a mesorregião Sertão Pernambucano deu origem a duas novas mesorregiões: a mesorregião homônima Sertão Pernambucano e o São Francisco Pernambucano. A primeira compreende as microrregiões Sertão do Moxotó, Pajeú, Araripina e Salgueiro; e a segunda, as microrregiões Itaparica e Petrolina. Essas duas unidades, isto é, a nova mesorregião, equivalem à antiga microrregião Sertão Pernambucano. A reordenação foi efetuada com algumas alterações municipais. Assim é que as novas microrregiões Itaparica e Petrolina, fruto do desmembramento da microrregião Sertão Pernambucano do São Francisco, tiveram acrescentados os seguintes

\footnotetext{
${ }^{16}$ Trata-se de um quadro comparativo onde se procura evidenciar o resultado preliminar da correspondkíncia entre MRHs de distintos Censos, tendo-se por base a lista de municípios contidos em cada uma. Profindas mudanças foram operacionalizadas no Censo de 1995/1996: além da alteração do periodo de coleta para una parte dos dados, houve o fracionamento ou redefinição de várias MRHs; municipios de uma mesma MRH foram redistribuidos em antigas ou novas MRHs, em bloco ou individualmente. Nesse sentido, a tabela de equivalência reflete apenas uma primeira aproximação.
} 
municípios, respectivamente, Tacaratu (da ex MRH Sertão do Moxotó) e Terra Nova (da ex MRH Salgueiro).

Em conseqüência, a nova microrregião Sertão do Moxotó exclui o município de Tacaratu, mas foi-lhe acrescido outro municipio, o de Arcoverde, originado da microrregião homônima. De outra parte, a nova microrregião Salgueiro perdeu apenas o município de Terra Nova. As duas microrregiões do Sertão restantes, Araripina e Pajeú, correspondem exatamente às homônimas dos Censos anteriores.

Tabela 5.2. Equivalência aproximada entre microrregiões homogêneas do Censo Agropecuário de 1995/1996 e as microrregiões dos Censos do período 1970 a 1985 para o Estado de Pernambuco.

\begin{tabular}{|c|c|c|}
\hline CENSOS DE $1970,1975,1980 \mathrm{D}$ & CFNSOSDD 19951996 & GANSOS DE $1995 / 1996$ \\
\hline Microrregiōes Homogêneas & Microrregiōes Homogêneas & Mesorregiōes \\
\hline Sertáo do Moxoto & Sertho do voxolo & Sertäo Pernambacano \\
\hline Alto Pajeú & Pajeú & Sertão Pernambucano \\
\hline Aranpina & Araripina & Sertăo Pernambucano \\
\hline Salgueiro & Salgueiro & Sertão Pernambucano \\
\hline & & 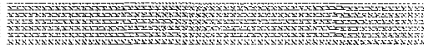 \\
\hline $\begin{array}{c}\text { Sertão Pernambucano do São } \\
\text { Francisco }\end{array}$ & Itaparica & $\begin{array}{l}\text { São Francisco } \\
\text { Pemambucano }\end{array}$ \\
\hline $\begin{array}{l}\text { Sertão Pernambucano do São } \\
\text { Francisco }\end{array}$ & Potrolina & $\begin{array}{l}\text { Säo Francisco } \\
\text { Pernambucano }\end{array}$ \\
\hline Recife & Nocife & Recife \\
\hline Recife + Mata Úmida & Suape & Recife \\
\hline 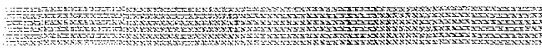 & Feriando de Noronha & Recife \\
\hline Mata Seca Pernambucana & Itamaracá & Recife \\
\hline Pat & & 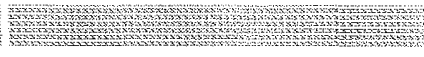 \\
\hline Mata Seca Pernambucana & Mata Setentrional Pernambucana & Mata Pernambucana \\
\hline Mata Imida Pemanbricana = & 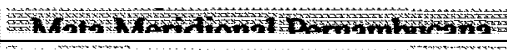 & 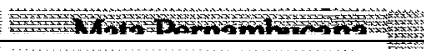 \\
\hline $\begin{array}{c}\text { Agreste Setentrional + Mata Seca + } \\
\text { Mata Úmida }\end{array}$ & Vitória de Santo Antão & Man Pernambucina \\
\hline Arcoverde & Vale do Ipanema & Agreste Pernambucano \\
\hline Agreste Setentrional & Alto Capibaribe & A 1 irste Rernambicano \\
\hline Agreste Setentrional & Médio Capibaribe & Agreste Pernambucano \\
\hline Agreste Medotional & Brejo Dotnambicano & Agreste Pernambucano \\
\hline Agreste Meridional & Garanhuns & Agreste Penambucano \\
\hline Vale do lpojuca & Vale do Ipojuca & Agreste Pemambucano \\
\hline
\end{tabular}


A nova mesorregião Recife é agora uma composição das antigas micro e mesorregião Recife acrescidas de três novas microrregiões: Fernando de Noronha, Suape e Itamaracá. A MRH Suape compõe-se de dois municípios, Cabo de Santo Agostinho e Ipojuca, provenientes, respectivamente, das ex MRHs Recife e Mata Úmida. Finalmente, a MRH Itamaracá, com três municipios: o novo municipio de Itapissuma, e os de Igarassu e Itamaracá, oriundos da ex MRH Mata Seca.

As novas microrregiões Mata Setentrional e Mata Meridional correspondem praticamente às antigas microrregiões, respectivamente, Mata Seca e Mata Úmida, fruto, entretanto, das seguintes alterações: na Setentrional, acha-se extraído o município de Chã de Alegria e na Meridional, os de Vitória de Santo Antão e Ipojuca.

Na mesorregião Mata Pernambucana, foi criada uma nova microrregião, a de Vitória de Santo Antão, composta de cinco municípios oriundos das ex MRH Agreste Setentrional (Chã Grande, Glória do Goitá e Pombos), Mata Seca (Chã de Alegria) e Mata Úmida (Vitória de Santo Antão).

Na mesorregião Agreste, a principal alteração foi o desmembramento da exs MRHs Agreste Setentrional e Agreste Meridional, originando, a primeira, as MRHs Alto Capibaribe e Médio Capibaribe, e a segunda, as MRHs Brejo Pemambucano e Garanhuns.

Na formação da MRH Alto Capibaribe foi-lhe acrescentado o municipio de Santa Cruz do Capibaribe, proveniente da ex MRH Vale do Ipojuca. Já o Médio Capibaribe compõe-se integralmente de parte de municipios exclusivamente da ex MRH Agreste Setentrional. Este também é o caso das novas MRHs Brejo Pemambucano e Garanhuns, cujos municípios são todos das ex MRH Agreste Meridional.

A nova MRH Vale do Ipojuca diferencia-se da homônima anterior apenas por não mais the pertencer o município de Santa Cruz do Capibaribe. Finalmente, a ex MRH Arcoverde passou a se denominar MRH Vale do Ipanema, tendo-lhe sido excluído o município de Arcoverde. 


\subsubsection{Variáveis utilizadas nas análises fatoriais}

A primeira etapa antes da reagregação dos dados, foi a de identificar e selecionar as variáveis que, posteriormente, haveriam de ser submetidas à análise fatorial. Numa primeira aproximação, selecionou-se um conjunto de variáveis indicadoras de modernização, extraídas com base na problemática do estado e nas hipóteses levantadas. Essa lista de variáveis foi modificada, em decorrência da existência dos dados e de testes realizados. Em linhas gerais, são variáveis mais ou menos comuns à maioria dos trabalhos sobre modernização envolvendo análise fatorial.

Inicialmente, identificou-se a existência de variáveis comuns aos Censos de 1950 e 1960. A tabela 5.3 resume a disponibilidade dessas informações. Algumas variáveis indicativas de modernização não foram objeto de pesquisa, havendo, portanto, lacunas. Constatou-se que as seguintes variáveis não foram investigadas em pelo menos um dos referidos Censos: máquinas para colheita, combustiveis, energia elétrica, financiamentos, área irrigada, valor da produção - existem dados apenas para quantidade e área colhida - e estabelecimentos associados às cooperativas. Ressalte-se, por outro lado, que as variáveis energia elétrica, financiamentos e área irrigada foram investigadas, pela primeira vez, no Censo de 1960. Em função do problema, o conjunto de variáveis citadas foi descartado para a análise dinâmica, pois a técnica adotada implica uma abordagem conjunta dos dados, para que os fatores obtidos tenham, cada um, o mesmo significado, e os respectivos escores microrregionais possam ser comparados ao longo do tempo. 
Tabela 5.3. Existência de variáveis especificas nos Censos de 1950 e 1960.

\begin{tabular}{lcc}
\hline \hline \multicolumn{1}{c}{ Variáveis } & Censo de 1950 & Censo de 1960 \\
\hline Estabelecimentos com força animal & Sim & Sim \\
Estabelecimentos com força mecânica & Sim & Sim \\
Adubos & Sim & Sim \\
Defensivos & Sim & Sim \\
Tratores & Sim & Sim \\
Arados com tração animal & Sim & Sim \\
Arados com tração mecânica & Sim & Sim \\
Máquinas para colheita & Não & Não \\
Combustiveis & Não & Não \\
Energia elétrica & Não & Sim \\
Financiamentos & Não & Sim \\
Área irrigada & Não & Sim \\
Valor dos bens & Sim & Sim \\
Valor da produção & Não & Não \\
Despesas da produção & Sim & Sim \\
Estabelecimentos associados às cooperativas & Não & Não \\
Trabalho temporário & Sim & Sim \\
Trabalho permanente & Sim & Sim \\
Trabalho familiar & Sim & Sim \\
\hline \hline
\end{tabular}

Após a seleção das variáveis e a reagregação dos dados, em conformidade com a unidade de análise microrregião homogênea, a próxima etapa consistiu na elaboração dos indicadores. Em seguida, após a etapa de testes, através da realização de análise fatorial estática, para 1960 e 1980,- cortes temporais esses escolhidos aleatoriamente - foram redefinidas as listas de variáveis e de indicadores. Concluída essa redefinição, foi feita a análise fatorial dinâmica (1950/1980), e, posteriormente, a análise fatorial estática, tomando-se os dados do Censo de 1995/96. 
Os indicadores, em sua maioria, são proporções ou razões cujos denominadores são a área trabalhada, a área explorada ou o total de pessoal ocupado. Na tabela 5.4, apresenta-se o conteúdo dos conceitos relacionados à área.

Tabela 5.4. Significado dos conceitos de área trabalhada, explorada e aproveitável.

\begin{tabular}{lccc}
\hline \multicolumn{1}{c}{ Utilização das terras } & Área trabalhada & Área explorada & $\begin{array}{c}\text { Área } \\
\text { aproveitável }\end{array}$ \\
\hline Lavouras permanentes & $\mathrm{X}$ & $\mathrm{X}$ & $\mathrm{X}$ \\
Lavouras temporárias & $\mathrm{X}$ & $\mathrm{X}$ & $\mathrm{X}$ \\
Pastagens plantadas & $\mathrm{X}$ & $\mathrm{X}$ & $\mathrm{X}$ \\
Pastagens naturais & & $\mathrm{X}$ & $\mathrm{X}$ \\
Matas plantadas & $\mathrm{X}$ & $\mathrm{X}$ & $\mathrm{X}$ \\
Matas naturais & & $\mathrm{X}$ & $\mathrm{X}$ \\
Terras produtivas & $\mathrm{não}$ & & $\mathrm{X}$ \\
utilizadas e em descanso & & & \\
\hline
\end{tabular}

Fonte: Classificação realizada a partir dos Censos Agropecuários, tabela "utilização das terras".

A área trabalhada engloba o conjunto de lavouras, sejam elas permanentes ou temporárias, acrescido das áreas relativas às pastagens e matas plantadas; enquanto que a área explorada representa o somatório da área trabalhada juntamente com as áreas de pastagens e matas naturais. Por fim, a área aproveitável representa a área total dos estabelecimentos, excluídas as terras improdutivas, ou ainda, a soma da área explorada acrescida das terras produtivas não-utilizadas e em descanso.

Além dos conceitos relacionados à utilização das terras, adotou-se uma medida de homogeneização da força de trabalho, referente às categorias de pessoal ocupado, segundo sexo e idade. Trata-se da medida "equivalente-homem", proposta por Silva \& Kageyama (1983), utilizada na maioria dos trabalhos de análise fatorial sobre 
processos de modemização agrícola. Cada unidade de equivalente-homem (EH) representa a força de trabalho de um homem adulto ocupado em média 300 dias ao ano.

$\mathrm{Na}$ tabela 5.5, apresentam-se os diferentes pesos, através dos quais os totais de mulheres e crianças trabalhadoras, das categorias responsáveis e membros nãoremunerados (trabalho familiar), assalariados, parceiros e outra condição, foram convertidos em unidades de equivalente-homem.

Tabela 5.5. Pesos para conversão das categorias de trabalhador, segundo sexo e idade, em equivalente-homem.

\begin{tabular}{lccc}
\hline Categoria de trabalhador & $\begin{array}{c}\text { Homens maiores } \\
\text { de } \mathbf{1 4} \text { anos }\end{array}$ & $\begin{array}{c}\text { Mulheres maiores } \\
\text { de } \mathbf{1 4} \text { anos }\end{array}$ & $\begin{array}{c}\text { Menores } \\
\text { de } \mathbf{1 4} \text { anos }\end{array}$ \\
\hline $\begin{array}{l}\text { Responsáveis e membros } \\
\text { não-remunerados da familia }\end{array}$ & 1,00 & 0,60 & 0,40 \\
$\begin{array}{l}\text { Empregados permanentes e } \\
\text { temporários }\end{array}$ & 1,00 & 1,00 & 0,50 \\
$\begin{array}{l}\text { Parceiros } \\
\text { Outra condição }\end{array}$ & 1,00 & 0,66 & 0,40 \\
\hline \hline
\end{tabular}

Fonte: Tabela elaborada a partir da metodologia de conversão e pesos propostos por Silva \& Kageyama (1983).

Desta forma, uma vez procedida a conversão, todos os totais, referentes a qualquer categoria de trabalhador, passaram a ser expressos em unidades-homemadulto. A hipótese subjacente à necessidade de aplicação desse conversor, embora discutível, é a de que o rendimento do trabalho masculino adulto é superior ao das mulheres, excetuando-se a mão-de-obra feminina assalariada, e ao das crianças. Ou seja, sem a conversão, os totais das diferentes categorias não seriam estritamente comparáveis.

Objetivando obter a homogeneização dos dados relativos aos efetivos da pecuária considerados na análise dinâmica, mais precisamente, dos rebanhos bovino, bufalino, eqüino, asinino, muar, ovino e caprino, foi utilizada a metodologia de conversão 
em unidade-animal proposta por Hoffmann et al. (1984), citada e adotada, em trabalho de Tese, por Espírito Santo (1998, p.53). Os pesos de conversão ou de equivalência entre os rebanhos estão expostos na tabela 5.6.

Tabela 5.6. Pesos para conversão dos efetivos da pecuária em unidades-animal.

\begin{tabular}{cc}
\hline ESPECIE ANIMAL & NÚMERO DE UNIDADES-ANIMAL \\
\hline Bovinos & 1,00 \\
Bufalinos & 1,00 \\
Eqüinos & 1,00 \\
Muares & 0,70 \\
Suinos & 0,30 \\
Ovinos & 0,20 \\
Caprinos & 0,20 \\
\hline
\end{tabular}

Fonte: Hoffinann et al. (1984), apud Espirito Santo (1998, p.53).

Definidos os conceitos de área e as medidas de conversão da mão-deobra e dos efetivos da pecuária, foi elaborado um conjunto de indicadores que teve por fundamentos o conceito e a problemática da modernização e os trabalhos empíricos sobre o tema, que utilizaram a técnica estatística da análise fatorial: grosso modo, os indicadores originaram-se dos agregados temáticos da modernização, sejam com referência às causas e conseqüências do processo, sejam aos elementos transmissores pelos quais a modernização se manifesta.

\subsection{Teste dos indicadores (análise fatorial estática para 1960 e 1980)}

Antecodendo as análises fatoriais dinâmica (1950/80) e estática (1995/96), foi efetuado um teste de um conjunto inicial de 35 indicadores, no âmbito da 
análise fatorial, para aferir a contribuição de cada um na formação das estruturas compósitas, isto é, os fatores de modemização.

Procurou-se abranger tanto dados oriundos do trabalho de recomposição municipal (Censos de 1950 ou 1960) quanto de dados censitários mais próximos (1970, 1980 ou 1995/96). Nesse sentido, foram selecionados, aleatoriamente, respectivamente, os Censos de 1960 e 1980, de cujos dados foram elaborados indicadores, em uma listagem bastante ampla.

O resultado foi a confirmação da validade ou pertinência de parte dos indicadores e a identificação de algumas lacunas, ou seja, variáveis ausentes, mas importantes na análise da modemização. Algumas variáveis importantes, apesar de sua validade, não foram aproveitadas, em face da indisponibilidade de informações no Censo de 1950, considerando-se que se necessitava da existência de comparabilidade intercensitária, para análise dinâmica dos dados.

O teste serviu para delimitar um novo conjunto de indicadores, que foram utilizados na análise fatorial dinâmica para o periodo 1950/1980. Forneceu, também, resultados importantes acerca da posição relativa das microrregiões homogêneas do Estado de Pernambuco, quanto à modernização, nos dois cortes temporais: 1960 e 1980.

\subsubsection{Indicadores de modernização utilizados para teste na análise fatorial estática para 1960 e 1980}

Com objetivo de captar e testar a estrutura temática de variáveis mencionadas no item 5.2.1, foi elaborado um conjunto inicial de indicadores, apresentados a seguir: trata-se de um total de 35 indicadores observados em 12 microrregiões homogêneas em 1960 e 1980. O teste foi feito através de análise estática para esses dois cortes temporais. Observe-se que os dados de 1960 foram recompostos manualmente da unidade zona fisiográfica, em que se achavam apresentados, para a microrregião homogênea. 
$\mathrm{X} 1$ = percentagem dos estabelecimentos que usam força mecânica

$\mathrm{X} 2$ = percentagem dos estabelecimentos que usam força animal

$\mathrm{X} 3$ = percentagem dos estabelecimentos que usam força humana

X4 = número de tratores / área trabalhada

X5 = número de tratores / equivalente-homem

X6 = número de arados de tração mecânica / área trabalhada

X7 = número de arados de tração animal / área trabalhada

$\mathrm{X} 8$ = percentagem dos estabelecimentos que usam energia elétrica

$\mathrm{X} 9=$ percentagem dos estabelecimentos que usam adubos químicos

$\mathrm{X} 10=$ percentagem dos estabelecimentos que usam adubos orgânicos

$\mathrm{X} 11$ = percentagem dos estabelecimentos que obtiveram financiamentos

$\mathrm{X} 12$ = valor total dos bens / área explorada

$\mathrm{X} 13$ = valor total dos bens / equivalente-homem

X14 = valor dos bens (prédios, construções, animais, veículos, máquinas e instrumentos agrários e maquinaria) / área explorada

$\mathrm{X} 15$ = valor dos bens (prédios, construções, animais, veículos, máquinas e instrumentos agrários e maquinaria) / equivalente-homem

$\mathrm{X} 16$ = despesa total da produção / área explorada

$\mathrm{X} 17$ = despesa total da produção / equivalente-homem

$\mathrm{X} 18$ = percentagem das despesas com salários / despesa total

$\mathrm{X} 19=$ percentagem de despesas com adubos, corretivos, sementes, mudas, defensivos agrícolas, alimentação e trato de animais / despesa total

$\mathrm{X} 20$ = despesas com adubos, corretivos, sementes, mudas, defensivos agrícolas, alimentação e trato de animais / área explorada

$\mathrm{X} 21$ = despesas com adubos, corretivos, sementes, mudas, defensivos agrícolas, alimentação e trato de animais / equivalente-homem

$\mathrm{X} 22$ = despesas com adubos / área explorada

$\mathrm{X} 23$ = despesas com adubos / área trabalhada

X24 = despesas com defensivos / área explorada

X25 = despesas de alimentação e trato de animais / área de pastagens

X26 = percentagem da área com pastagens plantadas / área total de pastagens

X27 = percentagem da área produtiva não utilizada / área aproveitável

X28 = percentagem da área trabalhada / área aproveitável

X29 = percentagem da área de lavouras (permanentes + temporárias) / área aproveitável

X30 = área irrigada / área trabalhada

$\mathrm{X} 31$ = percentagem de empregados temporários $(\mathrm{EH}) /$ total do pessoal ocupado em equivalente-homem (EH)

$\mathrm{X} 32$ = percentagem de empregados permanentes $(\mathrm{EH}) /$ total do pessoal ocupado em equivalente-homem (EH) 
$\mathrm{X} 33$ = percentagem de assalariados temporários e permanentes (EH) / total do pessoal ocupado em equivalente-homem (EH)

X34 = percentagem de mão-de-obra familiar (EH) / total do pessoal ocupado em equivalente-homem (EH)

X35 = percentagem de parceiros e outra condição $(\mathrm{EH})$ / total do pessoal ocupado em equivalente-homem (EH)

\subsection{Análise fatorial dinâmica para o período $1950 / 1960 / 1970 / 1980$}

De uma maneira geral, independentemente de a análise fatorial ser estática ou dinâmica, essa técnica estatística pressupõe, resumidamente, quatro etapas: 1. obtenção da matriz de correlações entre as variáveis originais; 2. extração dos fatores, efetuada, opcionalmente, pelo método dos componentes principais; 3. rotação dos fatores, visando a tomar as variáveis originais mais fortemente associadas a determinado fator e mais fracamente aos demais, facilitando a interpretação dos resultados; 4. obtenção dos valores ou escores dos fatores, que são exatamente as projeções normalizadas dos pontos representativos das microrregiões sobre o eixo dos fatores.

Considerando-se os cortes temporais $(1950,1960,1970,1980)$ da investigação, se fossem realizadas análises estáticas, isto implicaria em quatro análises individualizadas para cada corte. Seriam obtidas quatro matrizes de correlações simples; os fatores para cada corte não seriam os mesmos, reduzindo-se as possibilidades de comparações dos escores microrregionais ao longo dos períodos intercensitários.

É de se mencionar que, para estudos de processos, como o é o de modernização, faz-se necessário verificar desdobramentos e tendências através do tempo. Entretanto, na análise fatorial estática, um estudo comparativo das dimensões estruturais do processo, entre os vários cortes, toma-se dificil, senão bastante arriscado, pois os fatores não necessariamente serão os mesmos. Ainda que possam apresentar significados semelhantes, será possível apenas fazer-se comparações sobre as posições relativas de cada microrregião. 
Em suma, se fosse feita uma análise fatorial para cada um dos quatro anos (1950, 1960, 1970 e 1980), os fatores não seriam os mesmos e não seria correto calcular, a título de exemplo, o crescimento do valor do primeiro fator entre 1950 e 1980 , para cada microrregião.

Alguns estudos de modemização agrícola utilizaram a análise fatorial dinâmica. Hoffnann et al. (1985), citados por Figueiredo (1996), investigaram 22 Unidades da Federação, tendo realizado uma abordagem estática, para 1980, e uma dinâmica de curto prazo, para o periodo 1970/1980. Em seguida, Tarsitano (1990) utilizou a análise dinâmica, através da abordagem conjunta dos dados de 1970 a 1985, referentes às MRHs dos Estados de Mato Grosso e Mato Grosso do Sul. “A metodologia adotada para a análise dinâmica consistiu em extrair os fatores do conjunto de dados nos quatro periodos observados para cada MRH: 1970, 1975, 1980 e 1985. Os escores dos fatores, obtidos para cada ano, permitiram observar o padrão de evolução desses fatores em cada MRH' (Figueiredo, 1996, p.23).

Hoffmann (1992) utilizou a análise dinâmica de curto prazo para 157 MRHs em 8 Estados das regiões Sul, Sudeste, Centro-Oeste e Nordeste, entre 1975 e 1980. Segundo Figueiredo (1996, p.24), “a principal diferença metodológica com relação à pesquisa de 1985 consistiu no fato de que a análise dinâmica não foi feita com base nas variações dos indicadores de modernização durante o período, mas de forma semelhante ao trabalho de Tarsitano (1990): as observações para 1975 e 1980 foram agrupadas em uma só análise. Os fatores de modemização selecionados pela análise fatorial pelo método dos componentes principais são comuns aos dois cortes temporais".

Na seqüência, a pesquisa efetuada por Figueiredo $(1996$, p.25) acerca da modernização agrícola em 299 MRHs do Nordeste, Sudeste e Sul, para 1975, 1980 e 1985, segue a metodologia adotada nos dois trabalhos precedentes: as observações para os três cortes temporais foram agnupadas em uma só análise. Segundo a autora, "com base nos escores dos fatores, é possivel analisar a natureza e a velocidade da modemização entre 1975 e 1985, sendo possivel, ainda, fazer comparações entre sua dinâmica nos dois qüinqüênios $75 / 80$ e 80/85". 
Para se poder verificar as variações de crescimento dos valores dos fatores ao longo dos periodos intercensitários (1950, 1960, 1970 e 1980), em cada microrregião homogênea, foi feita uma análise dinâmica, e, em conseqüência, agregandose as observações referentes aos quatro cortes, semelhantemente aos trabalhos de Tarsitano (1990), Hoffmann (1992) e Figueiredo (1996).

Seja X1 a matriz 12 x 25 com os valores dos 25 indicadores em 1950; seja X2 a matriz 12 x 25 com os valores dos 25 indicadores em 1960; identicamente, X3 e X4, com os valores dos 25 indicadores, respectivamente, em 1970 e 1980. Define-se, então, a matriz $48 \times 25$ :

$$
\left[\begin{array}{l}
X 1 \\
X 2 \\
X 3 \\
X 4
\end{array}\right] \Rightarrow R=X X^{\prime} \text { (matriz das correlações simples) }
$$

A análise fatorial foi aplicada a essa matriz, extraindo-se, em seguida, os fatores, e, retendo-se a quantidade de fatores que se julgou conveniente, em função da parcela da variância que o conjunto de fatores escolhidos pôde explicar. Agora, os fatores são os mesmos, independentemente do período. Quer dizer, partiu-se de uma mesma matriz de correlações simples, que gerou uma única matriz de cargas fatoriais.

Diferentemente da análise estática, o data-set na análise dinâmica é único; não está fracionado em quatro data-sets. Desta forma, a cada fator foi atribuído um mesmo significado, independentemente do ano de referência.

Entretanto, os valores ou escores fatoriais para cada microrregião, segundo cada ano, são diferentes. Com base nas variações temporais desses valores, pôde-se verificar as tendências da modernização e as zonas diferenciais desse processo. 


\subsubsection{Dados estatísticos referentes aos indicadores de modernização para a análise dinâmica}

O principal critério que norteou forçosamente a escolha e o tipo de indicador foi o da existência da respectiva variável de origem e a forma de apresentação no Censo Agrícola de 1950. Em se tratando de indicadores elaborados para uma análise dinâmica englobando quatro períodos censitários, necessitava-se que os mesmos apresentassem algum grau de comparabilidade. Nesse sentido, houve que se efetuar a homogeneização de parte dos dados, em face das mudanças de critérios havidas nos Censos posteriores ao de 1950.

Uma primeira adaptação ocorreu com relação ao tipo de força empregada nos trabalhos agropecuários. Ao contrário dos anteriores, o Censo de 1980 não informou a quantidade de estabelecimentos com indicação de uso simultâneo de força animal e mecânica. Esses estabelecimentos estão incluídos duplamente entre os informantes de cada tipo de força. Em razão disso, os estabelecimentos com duplicidade de força, informados nos Censos de 1950, 1960 e 1960, foram inseridos entre os declarantes de força animal e igualmente entre os declarantes de força mecânica. Em conseqüência, $\mathrm{o}$ indicador $(\mathrm{Xl}=$ percentagem dos estabelecimentos que usam força mecânica) engloba os estabelecimentos que utilizaram apenas força mecânica e os com uso simultâneo de ambos os tipos de força; semelhantemente, o indicador (X2 = percentagem dos estabelecimentos que usam força animal) engloba os estabelecimentos que utilizaram força animal e os com uso concomitante de ambas forças.

Em relação ao indicador $\mathrm{X} 3$ (percentagem dos estabelecimentos que usam força humana), o Censo de 1980 não informou diretamente esse tipo de força. Para suprir essa lacuna, para 1980, foi utilizado o total de estabelecimentos não declarantes do uso de força mecânica ou animal.

Também para a análise dinâmica, tomou-se a alternativa mais simples e segura, de utilizar as variáveis expressas em valores monetários (valor dos bens e despesas da produção) apenas em distribuições percentuais, ou seja, a participação 
relativa de bens ou despesas nos totais a preços correntes. Considere-se que a estrutura de preços relativos haja sofrido grandes variações nesse período de 30 anos (1950 a 1980), agravadas pelos planos econômicos e reformas monetárias que se sucederam nesse longo período. A correção pelo IGP/FGV não refletiria integralmente as alterações reais de preços.

Acrescente-se o problema concernente aos períodos de referência dos Censos. Segundo Figueiredo (1996, p.35), “as variáveis dadas em unidades monetárias como, por exemplo, valor das despesas, receitas, financiamentos, produção, etc, têm como período de referência o ano em que o Censo foi realizado e, neste caso, os valores monetários são deflacionados pelo índice médio do ano em questão. Em períodos de altas inflacionárias os entrevistados estão mais sujeitos a incorrer em erro ao informar sobre os valores pagos ou recebidos. Ademais, o fato de se desconhecer a época do ano em que se deram as transações comerciais impede que se consigam valores reais mais precisos".

Considere-se ainda a variável valor dos bens, cuja declaração obedece a datas de referência e não períodos (ano civil). O Censo de 1950 tem uma data diferente ( $1^{\circ}$ de julho) da do Censo de 1960 ( $1^{\circ}$ de setembro), que por sua vez é diferente da que foi utilizada nos Censos de 1970 e 1980 (31 de dezembro). Esse fato coloca mais uma restrição para a deflação de valores monetários.

Para os indicadores $\mathrm{X} 9$ e X10, mais especificamente em relação ao valor das terras, houve que se fazer a homogeneização do conteúdo dessa variável. Os Censos de 1950 e 1960 incluem no valor das terras, os das lavouras permanentes, matas e florestas; e os Censos de 1970 e 1980 incluem em terras somente o valor das matas e florestas naturais. A solução homogeneizadora foi a de incluir no valor das terras, nos quatro cortes temporais, tanto as lavouras permanentes quanto as matas e florestas, naturais ou plantadas.

Para o indicador (X12), referente às despesas com insumos necessários à produção, foi utilizado o título "percentagem de despesas com adubos, corretivos, sementes, mudas e defensivos agrícolas / despesa total", segundo a denominação constante no Censo de 1980. Em 1950 e 1960, ao invés de adubos e corretivos, e de 
defensivos agrícolas, esses insumos foram apresentados como adubos e fertilizantes, e inseticidas e fungicidas; e em 1970, como adubos e corretivos, e inseticidas e fungicidas. Não foi possivel incluir nesse rol, as despesas com alimentação e trato dos animais, em razão de o Censo de 1950, diferentemente dos demais, haver apresentado essa rubrica em “outras despesas".

No que concerne ao indicador X15 (unidade-gado / área de pastagens), para 1950, aos efetivos da pecuária, foram adicionados os bovinos e eqüinos arrolados fora dos estabelecimentos e os animais de trabalho e de sela. Segundo informa o Censo de 1960, "Os critérios adotados na pesquisa em 1950, "apresentam as seguintes diferenças: os animais de propriedade particular dos empregados, meeiros e parceiros residentes foram incluidos nos efetivos do estabelecimento; os animais de trabalho e/ou de sela foram investigados separadamente". Entretanto, no Censo de 1960, os "animais pertencentes ao pessoal residente nos estabelecimentos foram divulgados separadamente". Também assim o foram os animais que se encontravam fora do estabelecimento. Em razão disso, adicionou-se aos efetivos da pecuária esses totais informados em separado. Nos Censos de 1970 e 1980, só foram divulgados em separado os totais pertencentes ao pessoal residente. Para se uniformizar com o critério adotado pelo Censo de 1950, somou-se o total de cada rebanho pertencente aos residentes, ao efetivo da pecuária dos estabelecimentos.

Feita a uniformização dos efetivos da pecuária, para os quatro Censos, segundo os diferentes rebanhos, realizou-se a conversão dos totais em unidades-animal, segundo os pesos propostos.

Em relação ao pessoal ocupado, há algumas restrições de comparabilidade, principalmente no que se refere à mão-de-obra assalariada temporária: a primeira refere-se às datas de referência utilizadas nos Censos: no de 1950, os dados são de $1^{\circ}$ de julho, enquanto o seguinte, de 1960, a investigação refere-se a $1^{\circ}$ de setembro. Nos Censos de 1970 e 1980 a data de referência é a de 31 de dezembro.

Ressalte-se que, sucessivamente, de julho a dezembro, há uma queda do emprego agrícola no Sertão e Agreste. De uma maneira geral, é o primeiro semestre o 
periodo de demanda máxima de força de trabalho. Ou seja, a comparabilidade está prejudicada, pois se estão tomando períodos de relativa maior utilização de mão-de-obra, mais o Censo de 1950 do que o de 1960, para o Agreste e o Sertão, com períodos de entressafra, caso dos Censos de 1970 e 1980 (dezembro). A região um pouco menos prejudicada é a Mata, onde a lavoura canavieira tem seu ápice de demanda de emprego no segundo semestre.

Para 1950, em relação ao indicador X25 (percentagem de parceiros e outra condição / total de pessoal ocupado em equivalente-homem) foi agregado o pessoal de outra condição (moradores, agregados, etc.), segundo totais de 1960. Essa categoria não foi pesquisada em 1950, ao contrário dos Censos posteriores. Caso não fosse feita essa inclusão, o indicador para 1950 estaria subestimado, prejudicando a comparabilidade entre o conjunto de dados censitários posteriores. Por outro lado, considere-se que a categoria "pessoal de outra condição" não deve ter sofrido alteração significativa no período1950/60, facilitando essa inserção.

Outra diferença refere-se à distribuição por idade, realizada pelo Censo de 1950: a mão-de-obra masculina e feminina, segundo categorias, encontra-se classificada entre maiores e menores de 15 anos. Diferentemente, nos Censos posteriores, a idade de corte é a de 14 anos. Em face dessa dupla classificação, para conversão do pessoal ocupado informado no Censo de 1950, em equivalente-homem, teve-se que se utilizar a idade limite de 15 anos para separar os menores e maiores, ao invés de 14 anos, aplicando-se, em seguida, os respectivos pesos.

Em relação ao pessoal ocupado, decidiu-se: a) não incluir os serviços de empreitada, nem no total de salários, nem no total de pessoal ocupado em equivalentehomem (EH), considerando-se que essa modalidade de serviço não foi informada nos Censos de 1950 e 1960; b) não fazer estimativas do emprego temporário, por idêntica razão. 


\subsubsection{Indicadores de modernização para a análise dinâmica do periodo $1950 / 80$}

Esse segundo conjunto, totalizando 25 indicadores utilizados para a análise dinâmica, foi fruto da fase de teste, além das hipóteses e problemática da modernização, e também da limitação de comparabilidade entre os quatro Censos (1950, 1960,1970 e 1980). Sua principal finalidade foi a de identificar as tendências do processo e as zonas diferenciais da modemização ao longo do tempo.

$\mathrm{Xl}=$ percentagem dos estabelecimentos que usam força mecânica

$\mathrm{X} 2$ = percentagem dos estabelecimentos que usam força animal

$\mathrm{X} 3$ = percentagem dos estabelecimentos que usam força humana

X4 = número de tratores / área trabalhada

X5 = número de tratores / equivalente- homem

X6 = número de arados de tração mecânica / área trabalhada

X7 = número de arados de tração animal / área trabalhada

X8 = número de arados de tração mecânica e animal / equivalentehomem

X9 = percentagem do valor dos bens (exceto terras e culturas) / valor total dos bens

$\mathrm{X} 10=$ percentagem do valor de máquinas e instrumentos agránios / valor total dos bens

$\mathrm{X} 11$ = percentagem das despesas com salários / despesa total

$\mathrm{X} 12$ = percentagem de despesas com adubos, corretivos, sementes, mudas e defensivos agrícolas / despesa total

X13 = percentagem da área com pastagens / área explorada

X14 = percentagem da área com pastagens plantadas / área total de pastagens

X15 = unidade-gado / área de pastagens

$\mathrm{X} 16$ = número de litros de leite / vacas ordenhadas

$\mathrm{X} 17$ = percentagem da área de lavouras (permanentes + temporárias) / área explorada

X18 = percentagem da área de colheita da cana-de-açúcar / área trabalhada

X19 = percentagem da área de colheita do feijão / área trabalhada

X20 = percentagem da área com matas naturais + terras produtivas nãoutilizadas / área aproveitável

$\mathrm{X} 21$ = total de pessoal ocupado $(\mathrm{EH}) /$ área explorada 
X22 = percentagem de empregados temporários $(\mathrm{EH}) /$ total do pessoal ocupado em equivalente-homem (EH)

$\mathrm{X} 23$ = percentagem de empregados permanentes $(\mathrm{EH}) /$ total do pessoal ocupado em equivalente-homem (EH)

X24 = percentagem de mão-de-obra familiar $(\mathrm{EH}) /$ total do pessoal ocupado em equivalente-homem (EH)

X25 = percentagem de parceiros e outra condição $(\mathrm{EH}) /$ total do pessoal ocupado em equivalente-homem (EH)

\subsection{Análise fatorial estática para $1995 / 96$}

A comparabilidade dos dados do Censo de 1995/96, com relação aos Censos anteriores, ficou bastante prejudicada, basicamente, por duas razões: a primeira, devido à mudança na data e no periodo de referência: segundo informa o IBGE (1997, p.27), "no Censo de 1995-1996, o periodo de referência para os dados de produção de lavouras... foi o de 01-08-1995 a 31-07-1996; e os dados estruturais (área, pessoal ocupado, maquinaria e infra-estrutura) referem-se a 31-12-1995, enquanto os de efetivos da pecuária e efetivos da lavoura permanente e de espécies florestais plantadas referem-se a 31-07-1996. Já o Censo Agropecuário anterior - o de 1985- teve como periodo de referência para os dados de produção o ano civil de 1985 e como data de referência para os dados estruturais o dia 31 de dezembro do mesmo ano, de forma idêntica ao estabelecido para os Censos anteriores", isto é, os de 1970 e 1980.

Em suma, se um dos problemas de comparabilidade entre os Censos de 1950 e 1960, e destes com relação aos de 1970 e 1980, era o das datas de referência distintas, o Censo de 1995-96 adicionou um outro: o da alteração do periodo de referência, não mais o ano civil.

A segunda razão que prejudicou a comparabilidade foi a alteração da divisão microrregional anterior, adotada a partir do Censo de 1970 e mantida nos três Censos seguintes: 1975, 1980 e 1985. Em resumo, existe comparabilidade direta apenas entre os quatro Censos efetuados entre 1970 e 1985. 
Os três problemas passaram a ser os Censos de 1950, 1960 e 1995/96. Relativamente aos dois primeiros, a solução encontrada foi a de recompor os dados municipais nas atuais microrregiões, em face da unidade adotada anterior ser a zona fisiográfica. Sem solução continuaram sendo as datas de referência, diferentes entre si (Censos de 1950 e 1960) e com relação aos Censos de 1970 e posteriores.

No caso do último Censo, poderia ter sido adotada a mesma solução efetuada para os Censos de 50 e 60: fazer a recomposição dos dados, desta feita, para as antigas microrregiões, ou vice-versa. Entretanto, diferentemente do caminho percorrido anteriormente, preferiu-se manter os dados do Censo de 1995/96 na sua regionalização micrrorregional original, por três motivos: o primeiro, pelo fato já apresentado, no sentido que uma maior riqueza de dados poderia ser extraída, uma vez que não se estaria mais limitado às restrições de comparações com os Censos a partir de 1950. O segundo motivo é o de revelar a caracterização da modernização num quadro microrregional novo, que servirá de referência para futuros trabalhos que utilizarem dados deste Censo e dos que o seguirão, se mantida a atual regionalização; o terceiro, foi em face da alteração simultânea do período e da data de referência, tornando bastante arriscada a inclusão desses dados em uma análise conjunta, para uma série temporal longa.

Em razão dos motivos apresentados, foi realizada uma análise fatorial estática.

\subsubsection{Indicadores de modernização para a análise estática de 1995/96}

Esse terceiro conjunto, que reúne 32 indicadores observados em 13 microrregiões e duas mesorregiões ${ }^{17}$, em 1995/96 - não mais amarrado à limitação de comparabilidade - pôde-se compor de uma listagem mais ampla de indicadores. A análise

\footnotetext{
${ }^{17}$ De um total de 19 microrregiões, foram tomadas como unidades de observação 13 MRHs. As seis restantes, por razões de simplificação, foram tratadas segundo as duas mesorregiões a que pertencern: Metropolitana do Recife (Femando de Noronha, Itamaracá, Recife, Suape) e São Francisco Pernambucano (Itaparica e Petrolina).
} 
estática para esse corte objetiva uma caracterização da situação da modernização da agricultura em passado mais próximo.

$\mathrm{XI}=$ percentagem dos estabelecimentos com indicação de uso de força mecânica

X2 = percentagem dos estabelecimentos com indicação de uso de força animal

$\mathrm{X} 3$ = número de tratores / área trabalhada

X4 = número de tratores / equivalente- homem

X5 = número de arados de tração mecânica / área trabalhada

X6 = número de arados de tração animal / área trabalhada

$\mathrm{X7}$ = percentagem dos estabelecimentos com indicação de uso de fertilizantes

$\mathrm{X} 8$ = percentagem dos estabelecimentos com indicação de uso de assistência técnica

X9 = valor dos financiamentos / área explorada

$\mathrm{X} 10=$ valor dos financiamentos / equivalente-homem

$\mathrm{X} 11$ = valor dos investimentos / área explorada

$\mathrm{X} 12$ = valor dos investimentos / equivalente -homem

$\mathrm{X} 13$ = valor da produção agropecuária (animal e vegetal) / área explorada

X14 = valor da produção agropecuária (animal e vegetal) / equivalentehomem

$\mathrm{X} 15$ = valor da despesa total da produção / área explorada

$\mathrm{X} 16$ = valor da despesa total da produção / equivalente-homem

$\mathrm{X} 17$ = percentagem do valor das despesas com salários / valor da despesa total

$\mathrm{X} 18$ = percentagem do valor das despesas com adubos, corretivos, sementes, mudas, agrotóxicos, medicamentos e alimentação dos animais / valor da despesa total

$\mathrm{X} 19$ = valor das despesas com adubos, corretivos, sementes, mudas, agrotóxicos, medicamentos e alimentação dos animais / área explorada

$\mathrm{X} 20$ = valor das despesas com adubos, corretivos, sementes, mudas, agrotóxicos, medicamentos e alimentação dos animais / equivalente-homem

$\mathrm{X} 21$ = valor das despesas com energia elétrica, combustiveis e lubrificantes / área explorada

X22 = valor das despesas com medicamentos e alimentação dos animais / hectare de pastagens

X23 = percentagem da área com pastagens / área explorada 
X24 = percentagem da área com pastagens plantadas / área total de pastagens

X25 = percentagem da área de lavouras (permanentes + temporárias) / área explorada

$\mathrm{X} 26$ = percentagem das terras produtivas não-utilizadas / área aproveitável

X27 = percentagem da área imigada / área trabalhada

$\mathrm{X} 28$ = total de pessoal ocupado $(\mathrm{EH}) /$ área explorada

X29 = percentagem de empregados temporários $(\mathrm{EH}) /$ total do pessoal ocupado em equivalente-homem (EH)

$\mathrm{X} 30$ = percentagem de empregados permanentes $(\mathrm{EH}) /$ total do pessoal ocupado em equivalente-homem (EH)

$\mathrm{X} 31$ = percentagem de mão-de-obra familiar $(\mathrm{EH}) /$ total do pessoal ocupado em equivalente-homem (EH)

$\mathrm{X} 32$ = percentagem de parceiros e outra condição $(\mathrm{EH}) /$ total do pessoal ocupado em equivalente-homem (EH) 


\section{RESULTADOS PRELIMINARES E DISCUSSÃO DO TESTE DOS INDICADORES}

Pretende-se, no decorrer do desenvolvimento desta Tese, conforme exposto na metodologia, efetuar duas análises fatoriais: a estática, segundo dados do último Censo, o de 1995/96, e a dinâmica, para o período 1950/80, para que se possa fazer comparações intercensitárias da evolução do processo de modemização, a partir do comportamento das "medidas de modemização" expressas pelos fatores ou dimensões estruturais do processo.

Antecedendo as referidas análises, dando seqüência ao plano proposto, apresentam-se, neste capitulo, os resultados do teste de parte dos dados, obtidos através de duas análises fatoriais estáticas, concernentes a 35 indicadores oriundos de uma seleção preliminar.

\subsection{Análise estática da modernização agrícola nas 12 MRHs do Estado de Pernambuco em 1960}

A partir da matriz $12 \times 35$ referente aos 35 indicadores de modernização observados em 12 microrregiões homogêneas em 1960, foi calculada a matriz de correlações simples ( 35 x 35), com base na qual, foram identificadas 6 raizes caracteristicas com valores superiores a 1. Normalmente, conforme já mencionado, somente os fatores associados a essas raizes são considerados para análise, constituindo- 
se num primeiro critério de seleção. O próprio processamento dos dados através do SAS, não se especificando o número máximo de fatores a serem extraídos (NFACTORS), utiliza como "default" o critério MINEIGEN, retendo somente os autovalores maiores que 1 (Alves, 1993).

Para facilitar a análise dos resultados, foram utilizados apenas três fatores que captaram $81,6 \%$ da variância total das variáveis originais. Conforme se pode visualizar na tabela 6.1 , o primeiro fator, isto é, a combinação linear das variáveis originais que pode explicar individualmente a maior parcela da variância, captou cerca de $61 \%$ da variância; o segundo, em ordem de contribuição para a variância total, $12 \%$, e o terceiro, $8 \%$.

Tabela 6.1. Raizes características da matriz de correlações simples $(35 \times 35)$ para as Microrregiões Homogêneas do Estado de Pernambuco, 1960.

\begin{tabular}{rrcc}
\hline Fatores & Raiz característica & \% da variância & \% acumulado \\
\hline 1 & 21,37 & 61,05 & 61,05 \\
2 & 4,28 & 12,24 & 73,29 \\
3 & 2,92 & 8,33 & 81.62 \\
4 & 2,18 & 6,23 & 87,85 \\
5 & 1,59 & 4,54 & 92.39 \\
6 & 1,03 & 2,95 & 95,34 \\
7 & 0,67 & 1,92 & 97.26 \\
8 & 0,47 & 1,36 & 98,62 \\
9 & 0,25 & 0,73 & 99.35 \\
10 & 0,13 & 0,37 & 99,72 \\
11 & 0,10 & 0,28 & 100 \\
Total & $35 *$ & 100 & 100 \\
\hline \hline
\end{tabular}

Fonte: Dados da pesquisa obtidos através do SAS.

* ordem da matriz 
Objetivando-se melhorar a leitura e a interpretação dos fatores, foi feita a rotação através do método Varimax. A tabela 6.2 apresenta os coeficientes de correlação entre cada fator e cada variável, as comunalidades, e a proporção da variância das variáveis originais explicada por cada um do três fatores, após a rotação. Os coeficientes de correlação com valores iguais ou superiores a 0,6 foram arbitrados como de forte associação entre o fator $\mathrm{e} o$ indicador, encontrando-se destacados em negrito.

Tabela 6.2. Coeficientes de correlação (cargas fatoriais), comunalidades e percentagem da variância explicada por cada fator após a rotação pelo método Varimax. Microrregiões Homogêneas do Estado de Pernambuco, 1960.

\begin{tabular}{|c|c|c|c|c|}
\hline \multirow{2}{*}{ Indicadores de modernizaçāo } & \multicolumn{3}{|c|}{ Coeficiente de Correlaçāo } & \multirow{2}{*}{ Comunalidade } \\
\hline & Fator 1 & Fator 2 & Fator 3 & \\
\hline $\mathrm{XI}=\%$ dos estabelecimentos que usam força mecânica & 0,967 & 0,161 & $-0,004$ & 0,961 \\
\hline $\mathrm{X} 2=\%$ dos estabelecimentos que usam força animal & 0,755 & 0,263 & $-0,224$ & 0,689 \\
\hline $\mathrm{X} 3=\%$ dos estabelecimentos que usam força humana & $-0,928$ & $-0,223$ & 0,155 & 0,936 \\
\hline $\mathrm{X} 4=\mathrm{n}^{\circ}$ de tratores $/$ área trabalhada & 0,948 & 0,246 & $-0,024$ & 0,960 \\
\hline$X 5=n^{\circ}$ de tratores $/$ equivalente - homem & 0,943 & 0,242 & $-0,040$ & 0,949 \\
\hline $\mathrm{X} 6=\mathrm{n}^{\circ}$ de arados de tração mecânica $/$ área trabalhada & 0,880 & 0,295 & $-0,185$ & 0,897 \\
\hline$X 7=n^{\circ}$ de arados de tração animal / área trabalhada & 0,430 & 0,437 & $-0,228$ & 0,428 \\
\hline $\mathrm{X} 8=\%$ dos estabelecimentos que usam energia elétrica & 0,964 & 0,068 & $-0,101$ & 0,944 \\
\hline $\mathrm{X} 9=\%$ dos estabelecimentos que usam adubos quimicos & 0,907 & $-0,192$ & 0,249 & 0,921 \\
\hline $\mathrm{X} 10=\%$ dos estabelecimentos que usam adubos orgânicos & 0,946 & 0,139 & $-0,110$ & 0,926 \\
\hline $\mathrm{X} 11=\%$ dos estabelecimentos que obtiveram financiamentos & 0,462 & 0,209 & $-0,470$ & 0,478 \\
\hline X12 = valor total dos bens / área explorada & 0,672 & 0,564 & $-0,305$ & 0,862 \\
\hline $\mathrm{X} 13$ = valor total dos bens / equivalente-homem & 0,901 & 0,260 & $-0,005$ & 0,879 \\
\hline $\begin{array}{l}\text { X14 = valor dos bens (prédios, construfões, etc.) / área } \\
\text { explorada }\end{array}$ & 0,554 & 0,536 & $-0,416$ & 0,767 \\
\hline $\begin{array}{l}\text { X15 = valor dos bens (prédios, construf̧ões etc.) } / \\
\text { equivalente-homem }\end{array}$ & 0,873 & $-0,123$ & 0,152 & 0,800 \\
\hline X16 = despesa total da produção / área explorada & 0,633 & 0,747 & $-0,003$ & 0,959 \\
\hline X17 = despesa total da produção / equivalente-homem & 0,768 & 0,597 & 0,122 & 0,961 \\
\hline $\mathrm{X} 18$ = \% das despesas com salários / despesa total & 0,319 & 0,792 & 0,271 & 0,802 \\
\hline
\end{tabular}


Continuação Tabela 6.2

\begin{tabular}{|c|c|c|c|c|}
\hline \multirow{2}{*}{ Indicadores de modernização } & \multicolumn{3}{|c|}{ Coeficiente de Correlação } & \multirow{2}{*}{ Comunalidade } \\
\hline & Fator 1 & Fator 2 & Fator 3 & \\
\hline $\begin{array}{l}\text { X19 = \% de despesas com adubos, corretivos etc. / despesa } \\
\text { total }\end{array}$ & 0,240 & $-0,808$ & 0,032 & 0,711 \\
\hline $\begin{array}{l}\text { X20 = despesas com adubos, corretivos, sementes etc. / área } \\
\text { explorada }\end{array}$ & $\mathbf{0 , 8 4 9}$ & 0,473 & $-0,093$ & 0,953 \\
\hline $\begin{array}{l}\text { X21 = despesas com adubos, corretivos,etc / equivalente- } \\
\text { homem }\end{array}$ & 0,955 & 0,241 & 0,047 & 0,972 \\
\hline $\mathrm{X} 22$ = despesas com adubos / área explorada & $\mathbf{0 , 8 5 0}$ & 0,489 & 0,064 & 0,966 \\
\hline $\mathrm{X} 23$ = despesas com adubos $/$ área trabalhada & 0,863 & 0,382 & 0,187 & 0,926 \\
\hline X24 = despesas com defensivos / área explorada & 0,417 & 0,755 & 0,278 & 0,822 \\
\hline $\begin{array}{l}\text { X25 = despesas de alimentação e trato de animais / área de } \\
\text { pastagens }\end{array}$ & 0,894 & 0,394 & $-0,103$ & 0,966 \\
\hline$X 26=\%$ da área com pastagens plantadas/área total past. & $-0,316$ & $-0,206$ & $-0,525$ & 0,418 \\
\hline X27 = \% da área produtiva não utilizada / área aproveitável & $-0,032$ & 0,005 & 0,630 & 0,397 \\
\hline X28 = \% da área trabalhada / área aproveitável & 0,258 & 0,762 & $-0,533$ & 0,932 \\
\hline X29 = \% da área de lavouras / área aproveitável & 0,239 & 0,812 & $-0,405$ & 0,881 \\
\hline X30 = área irrigada / área trabalhada & 0,083 & $-0,527$ & 0,506 & 0,541 \\
\hline $\begin{array}{l}\mathrm{X} 31=\% \text { de empregados temporários / total equivalente- } \\
\text { homem }\end{array}$ & 0,655 & 0,224 & 0,262 & 0,548 \\
\hline $\begin{array}{l}\mathrm{X} 32=\% \text { de empregados permanentes } / \text { total equivalente- } \\
\text { homem }\end{array}$ & $\mathbf{0 , 6 0 0}$ & 0,689 & 0,167 & 0,862 \\
\hline $\begin{array}{l}\mathrm{X} 33=\% \text { de assalariados (temp.+ perm.) } / \text { total equivalente- } \\
\text { homem }\end{array}$ & $\mathbf{0 , 7 4 0}$ & 0,537 & 0,253 & 0,900 \\
\hline X34 = \% de mão-de-obra familiar / total equivalente-homem & $-0,722$ & $-0,523$ & $-0,343$ & 0,913 \\
\hline $\begin{array}{l}\text { X } 35=\% \text { de parceiros e outra condição / total equivalente- } \\
\text { homem }\end{array}$ & $-0,006$ & $-0,026$ & 0,858 & 0,737 \\
\hline \% da variância explicada pelo fator após a rotação & 50,35 & 21,63 & 9,64 & \\
\hline
\end{tabular}

Fonte: Dados do IBGF, Censo Agríola de 1960 (PE), procencados através do SAS.

Note-se que o total da variância explicada pelos três fatores, em conjunto, continua o mesmo, antes e após a rotação $(81,62 \%)$, como pode ser observado na tabela 6.3 . 
Tabela 6.3. Percentagem da variância explicada por cada fator antes e após a rotação ortogonal.

\begin{tabular}{ccc}
\hline Fatores & Antes da rotaç̃o (\%) & Após a rotação (\%) \\
\hline Fator 1 & 61,05 & 50,35 \\
Fator 2 & 12,24 & 21,63 \\
Fator 3 & 8,33 & 9,64 \\
Total & 81,62 & 81,62 \\
\hline
\end{tabular}

Fonte: Dados da pesquisa obtidos através do SAS.

O primeiro fator (F1) passou a captar uma proporção menor da variância total das variáveis originais. Entretanto, o poder explicativo dos demais fatores aumentou, principalmente de F2, conforme pode ser visualizado na tabela 6.3.

Tomando-se os dados da tabela 6.2, classificou-se os coeficientes de correlação ou cargas fatoriais em 6 grupos ou intervalos de valores absolutos, como está apresentado na tabela 6.4. O Fator 1 apresenta correlações positivas, numa escala que vai de forte, moderada, e fraca, com $85 \%$ dos indicadores de modemização. Mas imperam com maior frequência as correlações positivas e fortes, englobando $60 \%$ do total dos 35 indicadores.

O Fator 2 também apresenta uma proporção elevada de correlações positivas com grande parte dos indicadores (77\%), porém cerca de $48 \%$ são correlações positivas fracas.

Para o Fator 3, ocorre uma inversão das posições anteriores: prevalecem as correlações negativas (54\%), em sua maioria correlações fracas (48\%). Entre as correlações positivas, prevalecem as fracas (37\%). 
Tabela 6.4. Percentagem de grupos de variáveis segundo o grau de correlação entre cada fator e a variável.

\begin{tabular}{ccccc}
\hline $\begin{array}{c}\text { Grau de correlação do } \\
\text { fator }\end{array}$ & $\begin{array}{c}\text { Intervalo } \\
\text { (valores absolutos) }\end{array}$ & $\begin{array}{c}\text { Fator 1 } \\
(\boldsymbol{\%})\end{array}$ & $\begin{array}{c}\text { Fator } 2 \\
\mathbf{( \% )}\end{array}$ & $\begin{array}{c}\text { Fator 3 } \\
\mathbf{( \% )}\end{array}$ \\
\hline positivo e forte & $(\mathbf{0 , 6}$ e mais) & $\mathbf{6 0 , 0 0}$ & 17,14 & 5,71 \\
positivo e moderado & $(0,5$ a menos de 0,6$)$ & 2,86 & 11,43 & 2,86 \\
positivo e fraco & $($ menos de 0,5$)$ & 22,86 & 48,57 & 37,15 \\
negativo e forte & $(0,6$ e mais) & 5,71 & 2,86 & 0 \\
negativo e moderado & $(0,5$ a menos de 0,6$)$ & 0 & 5,71 & 5,71 \\
negativo e fraco & $($ menos de 0,5$)$ & 8,57 & 14,29 & 48,57 \\
Total & & 100,00 & 100,00 & 100,00 \\
\hline
\end{tabular}

Fonte: Classificaçâo elaborada pela pesquisa a partir dos dados processados através do SAS.

De uma maneira geral, o objetivo da rotação foi alcançado com sucesso pois as correlações, para os três fatores, revelaram-se em cada caso, com maior freqüência ou relativamente fortes (F1) ou relativamente fracas (F2 e F3).

$\mathrm{O}$ fato de os três fatores, em especial os dois primeiros, associarem-se positivamente, embora em grau diferenciado, a quantidades expressivas de indicadores, torna-os potencialmente medidas de modemização, cada qual revelando faces distintas do processo. Um primeiro fator de modemização, de natureza mais avançada ou mais consistente, seria expresso por F1. Os demais poderiam ser considerados resíduos do primeiro, que é o fator geral. Portanto, descontada essa dimensão mais avançada de modernização, há uma segunda, indicada por F2; uma terceira dimensão, bem mais incipiente em termos do processo, poderia ser localizada através da variável sintética F3.

Caberia avaliar a capacidade explicativa dos três fatores em conjunto em relação a cada variável. Isto pode ser visto pelos valores das comunalidades listadas na tabela 6.2. Observa-se que, dos 35 indicadores, os três fatores explicariam grande parte da variância total de pelo menos 31 . Outros quatro, com percentuais inferiores a $50 \%$, 
não estão bem captados: X7 (número de arados de tração animal /área trabalhada), X11 (percentual de estabelecimentos que obtiveram financiamentos), X26 (percentual de pastagens plantadas / área total de pastagens), X27 (percentagem da área produtiva não utilizada / área aproveitável).

Considere-se, por outro lado, que para X30 (área irrigada / área trabalhada) e X31 (percentual de empregados temporários em equivalente-homem / total de pessoal ocupado em equivalente-homem $(\mathrm{EH})$ ), as respectivas comunalidades possuem valor em torno de 0,55 , indicando que os três fatores em conjunto explicariam moderadamente a variância desses indicadores.

Em função das baixas comunalidades apresentadas pelo conjunto dos três fatores para X7, X11, X26 e X27, efetuou-se, em nível de teste, a análise fatorial extraindo-se quatro fatores. Constatou-se que, após a rotação, para X7 ainda ocorria uma comunalidade de valor baixo: 0,45. Ao contrário, as comunalidades apresentaram-se elevadas para X26 $(0,81)$ e X30 $(0,89)$. Constatou-se, também, que o indicador X26 revelou-se forte e negativamente associado a F4, enquanto que o segundo (X30), forte e positivamente associado, também ao mesmo fator. Para X11, a comunalidade aumentou, mas, neste caso, não apresentando valor muito elevado: 0,54 .

Efetuando-se a análise fatorial extraindo-se seis fatores, justamente o total associado a raízes características maiores que a unidade, observou-se nos dados rotacionados, que todas as comunalidades, sem exceção, são elevadas, indicando que apenas seis fatores são adequados para captar parcelas expressivas da variância de todos os 35 indicadores. Ao Fator 4, associam-se forte e positivamente X30 (área irrigada), e forte e negativamente, X11 (financiamentos) e X26 (pastagens plantadas). Ao Fator 5, mostra-se forte e positivamente correlacionado, X7 (arados de tração animal). Enquanto X27 (terras produtivas não-utilizadas) aparece positivo e fortemente correlacionado com F6. Não obstante a comunalidade referente a X31 (empregados temporários) ter crescido significativamente com quatro e seis fatores, esse indicador continua a mostrar-se forte e positivamente associado apenas ao Fator 1 , independentemente do número de fatores extraídos para a análise fatorial. 
Apesar de um maior número de fatores conseguir captar em conjunto parcela mais expressiva da variância, optou-se por permanecer com apenas três, tanto para facilitar a interpretação dos dados, quanto pelo fato que, com vistas à análise do fenômeno modernização, a adição de mais fatores pouco acrescentaria. Considere-se, também, que fatores adicionais passam a explicar, tomados isoladamente, proporções cada vez menores da variância dos indicadores originais ${ }^{18}$. Levou-se também em consideração um critério mais empírico que foi o de reter determinada quantidade de fatores que, após a rotação, pudesse ser interpretável de modo coerente.

A análise das cargas fatoriais ou coeficientes de correlação, a seguir, de acordo com os dados apresentados na tabela 6.2, vai fornecer uma interpretação específica de cada fator, conduzindo ao entendimento de seu significado.

Considerando-se a análise fatorial com extração de três fatores, tem-se que o primeiro fator (F1) está forte e positivamente correlacionado com: X4 (número de tratores / área trabalhada); X6 (número de arados de tração mecânica / área trabalhada); X22 (despesas com adubos / área explorada); X23 (despesas com adubos / área trabalhada); X20 (despesas com adubos, corretivos, sementes, mudas, inseticidas, alimentação e trato de animais / área explorada); X25 (despesas de alimentação e trato dos animais / área de pastagens); X8 (percentagem dos estabelecimentos que usam energia elétrica); X10 (percentagem dos estabelecimentos que usam adubos orgânicos); X9 (percentagem dos estabelecimentos que usam adubos químicos). A leitura desse conjunto de indicadores sugere que F1 esteja medindo a intensidade da exploração da terra, pelo lado da incorporação de inovações mecânicas e químico-biológicas.

O Fator 1 também está positiva e fortemente associado aos indicadores: X1 (percentagem dos estabelecimentos que usam força mecânica); X2 (percentagem dos estabelecimentos que usam força animal); X5 (número de tratores / equivalente-homem); X13 (valor total dos bens / equivalente-homem); X15 (valor dos bens: prédios, construções, animais, veículos, máquinas e instrumentos agrários e maquinaria)/

\footnotetext{
${ }^{18} \mathrm{Na}$ análise fatorial extraindo-se seis fatores, a proporção da variância explicada por esse conjunto de fatores é de 95\%. Porém a variância explicada por cada fator decresce sucessivamente. Fator $1(43,49 \%)$, Fator 2 (18,36\%), Fator $3(13,79 \%)$, Fator $4(7,72 \%)$, Fator $5(6,38 \%)$ e Fator $6(5,59 \%)$.
} 
equivalente-homem); X17 (despesas total da produção / equivalente-homem); X21 (despesas com adubos, corretivos, sementes, mudas, inseticidas, alimentação e trato de animais / equivalente-homem). Esses indicadores revelam que F1 também está medindo o crescimento da relação capital/trabalho, no que se refere a incorporação de tecnologias mecânicas e químico-biológicas, paralelamente a uma poupança de mão-de-obra.

As associações fortes e simultâneas com adubos orgânicos e químicos, uso de forças animal e mecânica, sugere que a modemização expressa por F1 conteria uma dualidade tecnológica, no âmbito do estabelecimento ou, também, entre estabelecimentos.

O Fator 1 indica também modemização das relações sociais de produção, em função das associações positivas e fortes com : X33 (percentagem de assalariados temporários e permanentes (EH) / total do pessoal ocupado (EH) ); X31 (percentagem de empregados temporários (EH) / total do pessoal ocupado em equivalente-homem (EH) ); X32 (percentagem de empregados permanentes $(\mathrm{EH}) /$ total do pessoal ocupado em equivalente-homem (EH)). Observe-se, ainda, a associação negativa, embora fraca, entre o fator e X35 (parceiros e outra condição: agregados, moradores etc.).

Portanto, dos 35 indicadores de modemização, o Fator 1 guarda uma associação positiva e forte com 21 fatores, equivalentes a $60 \%$ do total. Menos de $15 \%$ dos indicadores estão associados negativamente ao fator. Destacam-se pela correlação negativa e forte, X3 (percentagem dos estabelecimentos que usam força humana) e X34 (percentagem de mão-de-obra familiar (EH) / total do pessoal ocupado em equivalentehomem (EH)). Trata-se, portanto, de um fator que está medindo uma modemização que exclui a produção familiar e relações de trabalho não-assalariadas.

Em síntese, o Fator 1 está medindo simultaneamente a intensificação da exploração da terra e a elevação da relação capital-trabalho. Dentre os três fatores é a principal medida sintética da modemização, principalmente pelo grande número de correlações positivas com a maioria dos indicadores de modernização. De sorte que esse fator explica uma proporção maior da variabilidade dos indicadores: 50\%. O Fator 1 será rotulado de "Modemização". 
O Fator 2 está associado forte e positivamente com: X16 (despesa total da produção / área explorada); X24 (despesas com defensivos / área explorada); X28 (percentagem da área trabalhada / área aproveitável); X29 (percentagem da área de lavouras (permanentes + temporárias) / área aproveitável); X18 (percentagem das despesas com salários / despesa total); X32 (percentagem de empregados permanentes (EH) / total do pessoal ocupado em equivalente-homem (EH) ). O Fator 2 está medindo a intensificação da exploração da terra, mais pelo aspecto da não-ociosidade, do que pela exploração intensiva através do uso de tecnologias modernas. Apesar da forte correlação positiva com o indicador X16 (despesas da produção) e com X24 (defensivos), a rubrica mais importante são os salários. Isto fica comprovado em face do forte e positivo coeficiente de correlação com X18 (salários) e a negativa e forte correlação do fator com X19 (despesas com inovações quimico-biológicas).

Exclui também a irrigação e a mão-de-obra familiar, dadas as correlações moderadas e negativas com X30 e X34. Embora de análise mais arriscada, é de se mencionar também as positivas, mas baixas correlações com a utilização de forças animal e mecânica, tratores, arados de tração mecânica e animal e uso de adubos orgânicos, este em termos de percentuais de estabelecimentos, e de despesas com adubos em geral. Mas, por outro lado, a correlação é negativa e fraca com o percentual de estabelecimentos que usam adubos químicos. Trata-se de produção mais extensiva em termos tecnológicos e intensiva no que se refere à pressão sobre a terra. Em função dessas características, F2 será denominado de "intensificação da exploração pelo trabalho assalariado".

O Fator 3 está forte e positivamente correlacionado com: X27 (percentagem da área produtiva não utilizada / área aproveitável) e X35 (percentagem de parceiros e outra condição $(\mathrm{EH})$ / total do pessoal ocupado em equivalente-homem (EH)). Apesar de exibir uma relação fraca, trata-se do único fator positivamente associado com X3 (percentagem dos estabelecimentos que usam com força humana). $\mathbf{O}$ coeficiente de correlação com X34 (mão-de-obra familiar ) continua negativo, porém fraco $(-0,343)$, enquanto que em F3 revelou-se forte $(-0,722)$ e em F2, mediano ou moderado $(-0,523)$. Ou seja, F3 exclui a modernização via estabelecimento familiar, 
porém, não com tanta intensidade, como em F1 e em F2. Privilegia o uso de força humana e, paralelamente, se opõe ao uso de inovações mecânicas: Xl (força mecânica), X4 e X5 (tratores) e X6 (arados de tração mecânica). As correlações também são negativas com referência aos indicadores emprego de força animal (X2) e arados de tração animal (X7). Ou seja, F3 não reflete esse conjunto de tecnologias poupadoras de força de trabalho. Entretanto, F3 está moderada e positivamente correlacionado com a utilização de irrigação.

Por outro lado, a forte correlação com o indicador "parceiros e trabalhadores de outra condição" e as correlações positivas, mas fracas, com indicadores referentes à mão-de-obra assalariada, faz supor que existam explorações com o emprego conjunto de diferentes relações de trabalho. Chama, também, atenção a relação inversa entre X27 (percentagem da área produtiva não utilizada / área aproveitável), que apresenta correlação positiva e forte, e X28 (percentagem da área trabalhada / área aproveitável) e X29 (percentagem da área de lavouras / área aproveitável), ambas com correlações negativas. Ou seja, existe um subaproveitamento do recurso terra. Paralelamente, há evidências de uma pecuária extensiva, dadas as correlações negativas de X25 (despesas de alimentação e trato dos animais por hectare de área de pastagens) e X26 (percentagem da área de pastagens plantadas sobre a área total de pastagens). $\mathrm{O}$ Fator 3 será denominado de "relações de trabalho não-modemizadas e subutilização do recurso terra".

Conforme já evidenciado, o Fator 1 é a principal medida, por excelência, de modernização, tanto no aspecto do aumento da relação capital-trabalho, quanto no que se refere à intensificação da exploração da terra, em termos do uso intensivo de tecnologias. Em verdade, os dois aspectos são um só: progresso tecnológico que leva ao uso crescente de máquinas e insumos, paralela e proporcionalmente a menor utilização de força de trabalho. Neste sentido, cresce a relação capital-trabalho, e as produtividades da terra e do trabalho são incrementadas. O Fator 1 captou conjuntamente as duas faces do fenômeno. 
Através da tabela 6.5, apresentam-se os valores dos fatores para as 12 microrregiões homogêneas de Pernambuco, listadas em blocos, segundo as mesorregiões que as contêm: na ordem, Mata ${ }^{19}$, Agreste e Sertão. O Fator 1, considerando-se seus dois desdobramentos referidos anteriormente, indica através de seus valores positivos que, na mesorregião da Zona da Mata, em 1960, todas as três microrregiões que a compõem (Recife, Mata Seca e Mata Úmida) revelavam modemização, principalmente, a primeira, a microrregião Recife, que apresentou a modernização mais consistente.

Tabela 6.5. Valores dos fatores, segundo microrregiões homogêneas, na análise fatorial em 35 indicadores. Pernambuco, 1960.

\begin{tabular}{|c|c|c|c|}
\hline Microrregião Homogênea & Fator 1* & Fator 2** & Fator 3*** \\
\hline Recife & 2,978 & 0,012 & $-0,488$ \\
\hline Mata Seca & 0,148 & 1,656 & 0,455 \\
\hline Mata Úmida & 0,099 & 1,777 & 0,910 \\
\hline Arcoverde & $-0,148$ & $-0,604$ & $-0,869$ \\
\hline Agreste Setentrional & $-0,730$ & 0,415 & $-1,235$ \\
\hline Agreste Meridional & $-0,426$ & 0,282 & $-0,851$ \\
\hline Vale do Ipojuca & $-0,233$ & $-0,426$ & $-0,755$ \\
\hline Araripina & $-0,676$ & 0,123 & 0,655 \\
\hline Salgueiro & $-0,568$ & $-0,138$ & 1,626 \\
\hline Sertão do São Francisco & 0,409 & $-1,839$ & 1,588 \\
\hline Sertão do Moxotó & $-0,422$ & $-0,845$ & $-0,409$ \\
\hline Alto Pajeú & $-0,432$ & $-0,414$ & $-0,627$ \\
\hline
\end{tabular}

Fonte: Dados do IBGE, Censo Agrícola de 1960 (PE), processados através do SAS.

* Modemização; ** Intensificação da exploração pelo trabalho assalariado; *** Relações de trabalho nãomodernizadas e subutilização do recurso terra.

\footnotetext{
${ }^{19}$ Até o Censo de 1960, a região era denominada "Zona do Litoral e Mata". A partir do Censo de 1970, essa zona tisiográfica foi fracionada nas três microrregiões, vigentes até o Censo de 1985. A partir do Censo de 1980, os dados também passaram a ser apresentados através da unidade mesorregião: Mata ( MRHs Mata Úmida e Mata Seca) e Recife, que coincide com a própria MRH Recife. Por razão de simplificação, a meso e micromegião Recife está sendo considerada, neste trabalho, como parte da mesorregião Mata.
} 
Na mesorregião Agreste, todas as quatro microrregiões mostraram-se ausentes desse processo, considerando-se uma modernização mais ampla. $\mathrm{Na}$ mesorregião Sertão, entre as suas cinco microrregiões, apenas o Sertão Pernambucano do São Francisco apresentou um quadro de modemização. Esses resultados são relativamente semelhantes aos constatados pela maioria dos trabalhos sobre modemização a partir dos anos 1970.

Em resumo, o processo de modemização já se localizava nas microrregiões da Zona da Mata e, também, no Sertão do São Francisco, pelo menos, desde os anos 1960. Na Mata, em razão da existência da lavoura comercial mais importante em Pernambuco, a da cana-de-açúcar, apesar da defasagem tecnológica. No São Francisco, face à irrigação fomentada pelos governos, principalmente a partir de meados da década dos anos 1950. O processo foi tão intenso que os dados de 1960 já passaram a refletir essa realidade. Apesar disso, nessa microrregião ainda existe acentuada dualidade tecnológica, em função dos amplos espaços não irrigados onde imperam uma agricultura de sequeiro, rotineira, em termos da ausência de tecnificação, e uma pecuária extensiva.

Descontado o padrão de modemização mais amplo e avançado expresso por F1, tem-se o Fator 2, que representa um tipo de modernização mais parcial, baseado, principalmente, na intensificação da exploração da terra, mais pelo uso do recurso trabalho, em especial, os assalariados permanentes. Entre os insumos, destacam-se apenas os defensivos. O Fator está indicando que um padrão de modernização mais restrita também ocorre em algumas microrregiões mais modemizadas reveladas pelo Fator 1: Recife, Mata Seca e Mata Úmida. Em outras palavras, coexistiriam nas microrregiões da Zona da Mata, tanto uma modemização de ponta (Fl), quanto uma modemização restrita baseada mais no recurso força de trabalho, do que nos insumos químicos, exceto os defensivos. Poder-se-ia tratar de um modo específico de condução da exploração, calcada, então, na estratégia de rebaixamento de custos ou maximização de lucros, via exploração intensiva da força de trabalho. 
Comparando-se os valores dos Fatores 1 e 2, para as microrregiões da Zona da Mata, observa-se que os de F2 são expressivamente mais elevados do que os de F1, para a Mata Seca e Mata Úmida, e o contrário, para a microrregião Recife. Quer dizer, nesta MRH predominava a modemização mais avançada, enquanto naquelas, uma modernização bem menos consistente. Essa constatação não está longe do que tem sido a exploração canavieira, baseada mais nos recursos naturais de fertilidade da terra e na utilização de mão-de-obra assalariada.

Valores positivos de F2 foram identificados também para o Agreste Setentrional e Agreste Meridional, além de uma microrregião situada no Sertão: Araripina. Ao passo que o Sertão do São Francisco foi a MRH que menos teve a ver com esse tipo de modemização, face ao elevado valor negativo do fator $(-1,84)$.

Em relação ao Fator 3, não se pode dizer que se trate de uma medida clara de modemização. F3 indica, principalmente, tanto aspectos relativos à subutilização ou subaproveitamento do potencial de terras quanto à utilização de relações de trabalho não modernizadas. Secundariamente, indica o uso de irrigação (inovações fisicas) e a pecuária extensiva. Os valores mais expressivos referem-se a Salgueiro e São Francisco e, moderadamente, a Araripina: devem-se, a aspectos relacionados à baixa utilização das terras disponiveis, principalmente a primeira microrregião, à irrigação (São Francisco) e ao uso de relações de trabalho não-modemizadas. Ao Sertão, de modo geral, tem sido predominante a prática da pecuária mais extensiva, particularmente se se considera que os dados se referem ao ano 1960, de modo que os valores dessas microrregiões sertanejas estão refletindo essa realidade. De outra parte, os valores positivos do Fator 3 com relação às microrregiões Mata Úmida e Mata Seca seriam devidos a utilização de relações de trabalho não-modemizadas e o subaproveitamento do recurso terra.

Considere-se, por outro lado, que a MRH Recife funcionaria quase como um termômetro da modernização. $\mathrm{O}$ valor negativo do Fator $3(-0,488)$, em relação à microrregião, revelaria sua exclusão de aspectos característicos de uma modemização mais incipiente. Como se sabe, até o início dos anos 60, foi bastante forte a utilização de agregados, os "moradores de engenho", como mão-de-obra na lavoura da cana-de- 
açúcar. Esse fato está refletido em F3 e, em consequência, nos valores positivos para a Mata Seca, e principalmente, para a Mata Úmida.

De outra parte, os elevados valores negativos das migrorregiões do Agreste, principalmente o Setentrional $(-1,235)$, devem-se à enorme pressão sobre a terra, dada a presença dos pequenos estabelecimentos, principalmente do minifúndio. Então, neste caso especifico, a leitura é feita com sinais trocados, ou seja, ao invés de subutilização, deve-se ler superutilização do recurso terra.

Considerando-se os três fatores como interpretativos de pelo menos algum tipo de modernização, esse processo, até 1960, excluiria duas microrregiões do Agreste (Arcoverde e Vale do Ipojuca) e duas do Sertão (Sertão do Moxotó e Vale do Pajeú). Os escores fatoriais, ou indices de modernização, estariam revelando as diferentes gradações do processo ou suas zonas diferenciais, segundo as estruturas ou dimensões a que pertencem.

\subsection{Análise estática da modernização agrícola nas 12 MRHs do Estado de Pernambuco em 1980}

A partir da matriz 12 × 35 referente aos 35 indicadores de modemização observados em 12 microrregiões homogêneas em 1980, foi calculada a matriz de correlações simples (35 x35) entre os indicadores, com base na qual, foram identificadas 6 raizes características com valores superiores a 1.

Para facilitar a análise dos resultados, foram utilizados apenas três fatores que captaram $81,5 \%$ da variância total das variáveis originais. De acordo ao que se apresenta na tabela 6.6, o primeiro fator, isto é, a combinação linear das variáveis originais que pode explicar individualmente a maior parcela da variância, captou $58 \%$ da variância; o segundo, em ordem de contribuição para a variância total, 13\%, e o terceiro, $9 \%$. 
Tabela 6.6. Raízes características da matriz de correlações simples $(35 \times 35)$ para as Microrregiões Homogêneas do Estado de Pernambuco. 1980.

\begin{tabular}{cccc}
\hline Fatores & Raiz característica & \% da variância & \% acumulado \\
\hline 1 & 20,44 & 58,41 & 58,41 \\
2 & 4,66 & 13,31 & 71,72 \\
3 & 3,42 & 9,78 & 81,50 \\
4 & 2,45 & 7,00 & 88,50 \\
5 & 1,59 & 4,54 & 93.04 \\
6 & 1,11 & 3,16 & 96,20 \\
7 & 0,54 & 1,55 & 97,75 \\
8 & 0,39 & 1,13 & 98,88 \\
9 & 0,16 & 0,46 & 99,33 \\
10 & 0,14 & 0,40 & 99,74 \\
11 & 0,09 & 0,26 & 100 \\
Total & $35^{*}$ & 100 & 100 \\
\hline \hline
\end{tabular}

Fonte: Dados da pesquisa obtidos através do SAS.

*ordem da matriz.

Objetivando-se melhorar a leitura e a interpretação dos fatores, foi feita uma rotação através do método Varimax. Note-se que o total da variância explicada pelos três fatores, em conjunto, continuou o mesmo, antes e após a rotação $(81,50 \%)$, como pode ser observado na tabela 6.7.

Tabela 6.7. Percentagem da variância explicada por cada fator antes e após a rotação ortogonal.

\begin{tabular}{ccc}
\hline Fatores & antes da rotação (\%) & após a rotação (\%) \\
\hline Fator 1 & 58,41 & 55,57 \\
Fator 2 & 13,31 & 13,58 \\
Fator 3 & 9,78 & 12,35 \\
Total & 81,50 & 81,50 \\
\hline
\end{tabular}

Fonte: Dados da pesquisa obtidos através do SAS. 
O primeiro fator $(\mathrm{F} 1)$ passou a captar uma proporção ligeiramente menor da variância total das variáveis originais, enquanto que, para F2, a participação mantevese praticamente a mesma. Entretanto, o poder explicativo do Fator 3 aumentou moderadamente, conforme pode ser visualizado na tabela 6.7 .

A tabela 6.8, a seguir, apresenta os coeficientes de correlação entre cada fator e cada variável, as comunalidades, e a proporção da variância das variáveis originais explicada por cada um dos três fatores, após a rotação. Seguindo o mesmo procedimento adotado na análise fatorial anterior, os coeficientes de correlação com valores absolutos iguais ou superiores a 0,6 foram arbitrados como de forte associação entre o fator e o indicador, encontrando-se destacados em negrito.

Tabela 6.8. Coeficientes de correlação (cargas fatoriais), comunalidades e percentagem da variância explicada por cada fator após a rotação pelo método Varimax. Microrregiões Homogêneas do Estado de Pernambuco, 1980.

\begin{tabular}{|c|c|c|c|c|}
\hline \multirow[t]{2}{*}{ Indicadores de modernização } & \multicolumn{3}{|c|}{ Coeficiente de Correlação } & \multirow[t]{2}{*}{ Comunalidade } \\
\hline & Fator 1 & Fator 2 & Fator 3 & \\
\hline $\mathrm{XI}=\%$ dos estabelecimentos que usam força mecânica & $-0,489$ & 0,326 & 0,749 & 0,906 \\
\hline $\mathrm{X} 2=\%$ dos estabelecimentos que usam força animal & $-0,605$ & 0,409 & $-0,154$ & 0,557 \\
\hline $\mathrm{X} 3=\%$ dos estabelecimentos que usam força humana & 0,688 & $-0,432$ & $-0,252$ & 0,724 \\
\hline $\mathrm{X} 4=\mathrm{n}^{\circ}$ de tratores $/$ área trabalhada & 0,940 & $-0,128$ & 0,041 & 0,902 \\
\hline $\mathrm{X} 5=\mathrm{n}^{\circ}$ de tratores $/$ equivalente - homem & $\mathbf{0 , 8 3 2}$ & $-0,031$ & 0,080 & 0,699 \\
\hline $\mathrm{X} 6=\mathrm{n}^{\circ}$ de arados de tração mecânica / área trabalhada & 0,935 & $-0,100$ & 0,139 & 0,904 \\
\hline $\mathrm{X} 7=\mathrm{n}^{\circ}$ de arados de tração animal $/$ área trabalhada & $-0,644$ & 0,304 & $-0,067$ & 0,512 \\
\hline $\mathrm{X} 8=\%$ dos estabelecimentos que usam energia elétrica & 0,916 & $-0,131$ & 0,160 & 0,881 \\
\hline$X 9=\%$ dos estabelecimentos que usam adubos quimicos & $\mathbf{0 , 8 1 7}$ & 0,050 & 0.422 & 0,848 \\
\hline $\mathrm{X} 10=\%$ dos estabelecimentos que usam adubos orgânicos & 0,690 & $-0,562$ & $-0,255$ & 0,857 \\
\hline $\mathrm{X} 11$ = \% dos estabelecimentos que obtiveram inanciamentos & $-0,171$ & 0,909 & 0,054 & 0,859 \\
\hline X12 = valor total dos bens / área explorada & $\mathbf{0 , 8 6 9}$ & $-0,346$ & $-0,258$ & 0,941 \\
\hline $\mathrm{X} 13$ = valor total dos bens $/$ equivalente-homem & $\mathbf{0 , 8 3 4}$ & $-0,292$ & $-0,090$ & 0,788 \\
\hline $\begin{array}{l}\text { X14 = valor dos bens (prédios, construções, etc.) / área } \\
\text { explorada }\end{array}$ & $\mathbf{0 , 7 9 5}$ & $-0,377$ & $\rightarrow, 261$ & 0,843 \\
\hline
\end{tabular}


Continuação Tabela 6.8

\begin{tabular}{|c|c|c|c|c|}
\hline \multirow[t]{2}{*}{ Indicadores de modernizaçāo } & \multicolumn{3}{|c|}{ Coeficiente de Correlação } & \multirow[t]{2}{*}{ Comunalidade } \\
\hline & Fator 1 & Fator 2 & Fator 3 & \\
\hline $\begin{array}{l}\mathrm{X} 15=\text { valor dos bens (prédios, construções etc.) } \\
\text { equivalente-homem }\end{array}$ & 0,640 & $-0,146$ & 0,289 & 0,515 \\
\hline X16 = despesa total da produção / área explorada & $\mathbf{0 , 9 5 8}$ & $-0,137$ & $-0,230$ & 0.989 \\
\hline X17 = despess total da produção / equivalente-homem & 0,949 & $-0,123$ & $-0,112$ & 0,929 \\
\hline X18 = \% das despesas com salánios / despesa total & $-0,271$ & 0,777 & $-0,368$ & 0,812 \\
\hline $\begin{array}{l}\text { X19 }=\% \text { de despesas com adubos, corretivos etc. / despesa } \\
\text { total }\end{array}$ & 0,023 & $-0,732$ & $-0,208$ & 0,580 \\
\hline $\begin{array}{l}\text { X20 = despesas com adubos, corretivos, sementes etc. / área } \\
\text { explorada }\end{array}$ & 0,901 & $-0,251$ & $-0,233$ & 0,929 \\
\hline $\begin{array}{l}\text { X21 = despesas com adubos, corretivos, etc / equivalente- } \\
\text { homem }\end{array}$ & $\mathbf{0 , 8 7 3}$ & $-0,297$ & $-0,153$ & 0,874 \\
\hline X22 = despesas com adubos / área explorada & 0,958 & $-0,007$ & -0.204 & 0,960 \\
\hline $\mathrm{X} 23$ = despesas com adubos $/$ área rabalhada & 0,960 & $-0,010$ & $-0,120$ & 0,937 \\
\hline X24 = despesas com defensivos / área explorada & $\mathbf{0 , 8 4 3}$ & $-0,107$ & $-0,126$ & 0,739 \\
\hline $\begin{array}{l}X 25 \text { = despesas de alimentação e trato de animais / área de } \\
\text { pastagens }\end{array}$ & $\mathbf{0 , 8 2 7}$ & $-0,181$ & $-0,167$ & 0,744 \\
\hline X26 = \% da área com pastagens plantadas/área total past. & $-0,088$ & $-0,677$ & $-0,379$ & $\bullet 610$ \\
\hline X27 = \% da área produtiva não utilizada / área aproveitável & 0,322 & 0,523 & $-0,516$ & 0,643 \\
\hline X28 = \% da área trabalhada / área aproveitável & 0,630 & $-0,433$ & $-0,525$ & 0,860 \\
\hline X29 = \% da área de lavouras / área aproveitável & $\mathbf{0 , 8 3 5}$ & $-0,130$ & $-0,435$ & $\bullet, 903$ \\
\hline X30 = área irrigada / área trabalhada & 0,172 & 0,086 & 0,905 & 0,855 \\
\hline $\begin{array}{l}\mathrm{X} 31=\% \text { de empregados temporánios / total equivalente- } \\
\text { homem }\end{array}$ & 0,793 & 0,399 & 0,233 & 0,843 \\
\hline $\begin{array}{l}\text { X32 = \% de empregados permanentes / total equivalente- } \\
\text { homen }\end{array}$ & 0,874 & 0,183 & $-0,214$ & 0,844 \\
\hline $\begin{array}{l}\mathrm{X} 33=\% \text { de assalariados (temp. }+ \text { perm. }) / \text { total equivalente- } \\
\text { homem }\end{array}$ & 0,912 & 0,256 & $-0,103$ & $\bullet, 908$ \\
\hline X34 = \% de mão-de-obra familiar / total equivalente-homem & $-0,913$ & $-0,258$ & $0, \mathbf{0 8 4}$ & 0,907 \\
\hline $\begin{array}{l}\text { X } 35=\% \text { de parceiros e outra condição / total equivalente- } \\
\text { homem }\end{array}$ & $-0,085$ & 0,061 & 0,955 & 0,924 \\
\hline \% da variância explicada por cada fator após a rotação & 55,57 & 13,58 & 12,35 & \\
\hline
\end{tabular}

Fonte: Dados do IBGE, Conso Agropzuário de 1980 (PE), procascados através do SAS. 
Tomando-se os dados da tabela 6.8, classificou-se os coeficientes de correlação ou cargas fatoriais em 6 grupos ou intervalos de valores absolutos, como está apresentado na tabela 6.9. O Fator 1 apresenta correlações positivas, numa escala que vai de forte à fraca, com $80 \%$ dos indicadores de modemização. Mas, imperam com maior frequêencia as correlações positivas e fortes, englobando $71 \%$ do total dos 35 indicadores.

Tabela 6.9. Percentagem de grupos de variáveis segundo o grau de correlação entre a variável e cada fator.

\begin{tabular}{llrrr}
\hline \begin{tabular}{c} 
Grau de correlação \\
\multicolumn{1}{c}{ do fator }
\end{tabular} & \multicolumn{1}{c}{$\begin{array}{c}\text { Intervalo } \\
\text { (valor absoluto) }\end{array}$} & $\begin{array}{c}\text { Fator 1 } \\
\mathbf{( \% )}\end{array}$ & \multicolumn{1}{c}{$\begin{array}{c}\text { Fator 2 } \\
\mathbf{( \% )}\end{array}$} & \multicolumn{1}{c}{$\begin{array}{c}\text { Fator 3 } \\
(\mathbf{\%})\end{array}$} \\
\hline positivo e forte & (0,6 e mais) & $\mathbf{7 1 , 4 3}$ & 5,71 & 8,57 \\
positivo e moderado & $(0,5$ a menos de 0,6$)$ & 0 & 2,87 & 0 \\
positivo e fraco & (menos de 0,5$)$ & 8,57 & 25,71 & 25,72 \\
negativo e forte & $(0,6$ e mais) & 5,71 & 5,71 & 0 \\
negativo e moderado & $(0,5$ a menos de 0,6$)$ & 0 & 2,86 & 5,71 \\
negativo e fraco & (menos de 0,5$)$ & 14,29 & $\mathbf{5 7 , 1 4}$ & $\mathbf{6 0 , 0 0}$ \\
Total & & 100,00 & 100,00 & 100,00 \\
\hline \hline
\end{tabular}

Fonte: Classificação elaborada pela pesquisa a partir dos dados processados através do SAS.

Contrariamente ao Fator 1, o segundo fator (F2) apresenta uma proporção elevada de correlações negativas com grande parte dos indicadores $(65 \%)$, sendo que a maioria, cerca de $57 \%$, apresenta correlações fracas.

Também para o Fator 3, prevalecem as correlações negativas (65\%), em sua maioria correlações fracas $(60 \%)$. Entre as correlações positivas, também prevalecem as fracas $(25 \%)$.

De maneira geral, o objetivo da rotação foi alcançado com sucesso pois as correlações, para os três fatores, revelaram-se em cada caso, com maior frequência ou relativamente fortes $(\mathrm{F} 1)$ ou relativamente fracas $(\mathrm{F} 2 \mathrm{e} \mathrm{F3})$. 
Assim como para 1960, também para 1980, Fl é uma medida por excelência de modemização, pelo fato de associar-se positivamente a uma quantidade expressiva de indicadores. Entretanto, os demais fatores (F2 e F3) revelaram muito mais um antagonismo em relação aos indicadores, em função da prevalência de coeficientes negativos de correlação, em torno de $65 \%$ para ambos. Entre as correlações positivas a maioria é fraca. Portanto, descontada a dimensão mais avançada de modernização, os resíduos desse processo indicados por F2 e F3, poderão revelar apenas aspectos de uma modernização incipiente, sugerindo tecnificação bastante parcial do processo produtivo, ou, ainda, a existência de uma estrutura moderna encravada em área majoritariamente tradicional.

Caberia avaliar a capacidade explicativa dos três fatores, em conjunto, em relação a cada variável. Isto pode ser possível através do exame dos valores das comunalidades listadas na tabela 6.8. Para a maioria dos indicadores, as comunalidades são bastante altas. Entretanto, é de se mencionar que quatro indicadores revelaram-se moderadamente captados pelo conjunto de fatores $(\mathrm{F} 1+\mathrm{F} 2+\mathrm{F} 3)$, apresentando comunalidades em torno de 0,5: X2 (percentagem dos estabelecimentos que usam força animal); X7 (número de arados de tração animal / área trabalhada); X15 (valor dos bens (prédios, construções, animais, veículos, máquinas e instrumentos agrários e maquinaria) / equivalente-homem) e X19 (percentagem de despesas com adubos, corretivos, sementes, mudas, inseticidas, alimentação e trato de animais / despesa total), respectivamente, com $0,557,0,512,0,515$ e 0,580 .

A análise fatorial com a extração de apenas três fatores vai facilitar a interpretação dos dados, conforme discutido na seção anterior, referente à análise para 1960. Observe-se que, dos 35 indicadores, os três fatores explicariam grande parte da variância de praticamente todos os dados originais. Em sendo assim, concluiu-se que a extração de apenas três fatores é suficiente para os propósitos do trabalho, não havendo necessidade de se reter quantidade maior de fatores. 
A leitura das cargas fatoriais ou coeficientes de correlação entre cada fator e os indicadores, cujos valores encontram-se apresentados na tabela 6.8 , fornecerá uma interpretação especifica de cada uma das três dimensões.

O Fator 1 apresentou associação positiva e forte com $71,43 \%$ dos indicadores de modemização. Por outro lado, associou-se negativa e fortemente a apenas três indicadores: X2 (percentagem dos estabelecimentos que usam força animal), X7 (arados de tração animal / área trabalhada) e X34 (mão-de-obra familiar). Esse fator, portanto, exclui a produção familiar.

A correlação negativa entre F1 e o indicador X1 (percentagem de estabelecimentos com força mecânica), comparativamente com as associações positivas do fator com X4 (tratores / área trabalhada), X5 (tratores / equivalente-homem) e X6 (arados de tração mecânica / área trabalhada), revela uma mecanização concentrada, isto é, pouco difusa em termos da maioria dos estabelecimentos, ao mesmo tempo, intensiva.

Apesar do Fator 1 estar forte e negativamente associado ao indicador X34 (mão-de-obra familiar), mostra-se correlacionado forte e positivamente com o indicador "estabelecimentos que usam força humana", bem como aos indicadores referentes ao trabalho assalariado (X31, X32, X33). Em outras palavras, essa primeira dimensão poderia estar retratando espaços geográficos onde está mais disseminada a utilização de força humana, assalariada, não-familiar.

Por outro lado, está forte e negativamente associado ao indicador "estabelecimentos que usam força animal" e moderada e negativamente aos que usam força mecânica. Ao mesmo tempo, está forte e positivamente associado aos indicadores de intensidade de uso de tratores e de arados de tração mecânica, e negativamente aos arados de tração animal. Portanto, além da mão-de-obra familiar, o Fatorl também exclui a exploração que emprega força animal. De outra parte, revela modemização em face de, no conjunto de estabelecimentos que lhe são representativos, ocorrer o uso intensivo de tecnologias mecânicas, mas não amplamente disseminadas, e utilização de mão-de-obra assalariada. 
O Fatorl está associado forte e positivamente a: X4 (número de tratores / área trabalhada); X6 (número de arados de tração mecânica / área trabalhada); X9 (percentagem dos estabelecimentos que usam adubos químicos); X10 (percentagem dos estabelecimentos que usam adubos orgânicos); X12 (valor total dos bens / área explorada); X14 (valor dos bens (prédios, construções, animais, veículos, máquinas e instrumentos agrários e maquinaria) / área explorada); X16 (despesa total da produção / área explorada); X20 (despesas com adubos, corretivos, sementes, mudas, inseticidas , alimentação e trato de animais / área explorada); X22 (despesas com adubos / área explorada); X23 (despesas com adubos / área trabalhada); X24 (despesas com defensivos / área explorada); X25 (despesas de alimentação e trato de animais / área de pastagens); X28 (percentagem da área trabalhada / área aproveitável); X29 (percentagem da área de lavouras (permanentes + temporárias) / área aproveitável). O Fator 1 está revelando, através desse conjunto de indicadores, a intensificação da exploração da terra.

O Fator 1 também está forte e positivamente associado a: X5 (número de tratores / equivalente- homem); X13 (valor total dos bens / equivalente-homem); X15 (valor dos bens (prédios, construções, animais, veículos, máquinas e instrumentos agrários e maquinaria) / equivalente-homem); X17 (despesa total da produção / equivalente-homem); X21 (despesas com adubos, corretivos, sementes, mudas, inseticidas, alimentação e trato de animais / equivalente-homem). Fl estaria indicando a intensidade do uso de capital em detrimento ao emprego, e, portanto, estará expressando o aumento da relação capital/trabalho.

Assim como para 1960, também para 1980, embora os fatores não sejam exatamente os mesmos, Fl está medindo simultaneamente tanto a intensidade de exploração da terra, em termos do uso intensivo de tecnologias por unidade de área , quanto a relação capital-trabalho, ou seja, emprego de tecnologias por unidade de mãode-obra ocupada. Em verdade, como já foi exposto anteriormente, os dois aspectos são um só: progresso tecnológico que leva ao uso crescente de máquinas e insumos, paralela e proporcionalmente a menor utilização de força de trabalho. Neste sentido, cresce a relação capital-trabalho, e as produtividades da terra e do trabalho são também 
incrementadas. O Fator 1 captou conjuntamente as duas faces do fenômeno e será denominado de "Modemização".

O Fator 2 está associado forte e positivamente a X11 (percentagem dos estabelecimentos que obtiveram financiamentos) e a X18 (percentagem das despesas com salários / despesa total). Por outro lado, está negativa e fortemente associado a X19 (percentagem de despesas com adubos, corretivos, sementes, mudas, inseticidas ,alimentação e trato de animais / despesa total) e a X26 (percentagem da área com pastagens plantadas / área total de pastagens). Essa segunda dimensão (F2), em termos gerais, sugeriria uma modemização baseada em estabelecimentos que tiveram acesso a financiamentos, oficiais e particulares, mas que apresentaram mais despesas com salários do que com insumos, e uma pecuária extensiva. Ou seja, a base técnica de produção estaria mais calcada no recurso trabalho. Poderia estar revelando mais um aspecto atrasado do processo de modemização, muito mais do que o indicado pelo Fator 2, em 1960.

Apesar de fraca, está positivamente correlacionado com a utilização de tração animal (X2 e X7) e adubos químicos (X9) e moderada e negativamente associado com a utilização de adubos orgânicos. Também está moderadamente associado, embora positivamente, com X27 (percentagem da área produtiva não utilizada / área aproveitável) e fraca e negativamente associado com X28 (percentagem da área trabalhada / área aproveitável) e X29 (percentagem da área de lavouras (permanentes + temporárias) / área aproveitável). O Fator 2 está revelando subutilização da terra, extensividade e tração animal. Sinteticamente, esse fator será rotulado "subutilização da terra e pecuária extensiva".

O Fator 3 está forte e positivamente associado a X1 (percentagem dos estabelecimentos que usam força mecânica), X30 (área irrigada / área trabalhada) e a X35 (percentagem de parceiros e outra condição (EH) / total do pessoal ocupado em equivalente-homem (EH)). Por outro lado, está positiva e fracamente associado aos indicadores de intensidade de uso de tratores e arados mecânicos (X4, X5 e X6). 
O Fator 3 revelaria, então, pelo lado da modernização, a irrigação e a utilização de força mecânica, embora relativamente disseminada, porém com baixa intensidade. Isto porque, não obstante o fator esteja associado positiva e fortemente com o indicador "percentagem dos estabelecimentos com uso de força mecânica", por outro lado, mostra-se positiva, mas fracamente correlacionado com os indicadores que medem a intensidade de uso, a exemplo dos tratores por unidade de área explorada. O Fator 3 também estaria indicando a utilização de relações de trabalho não-modernizadas: parceiros e outra condição.

Embora associado fracamente, foi o único fator que apresentou uma associação positiva com a mão-de-obra familiar. Por outro lado, mostrou-se fraco e negativamente associado ao assalariamento permanente. Dada à forte e positiva associação com X35, é possível que parceiros e trabalhadores de outra condição estejam sendo utilizados no lugar dos empregados permanentes. O Fator 3 está revelando aspectos de atraso, dualidade e transição. Essa dimensão será denominada de "irrigação e relações de trabalho não-modernizadas".

Através da tabela 6.10, apresentam-se os valores dos fatores para as 12 microrregiões homogêneas de Pernambuco. O Fator 1, considerando-se seus dois desdobramentos referidos anteriormente, indica através de seus valores positivos que, em 1980, a modernização continuava localizada nas mesmas microrregiões assinaladas pela análise fatorial anterior, referente a 1960: Recife, Mata Seca, Mata Úmida e Sertão Pernambucano do São Francisco.

Apesar de os fatores não serem os mesmos, já que os dados não se referem à análise fatorial dinâmica, contudo, pelo menos o Fator 1 , para os dois cortes temporais analisados, indica claramente "modemização". Nesse sentido, é possível arriscar-se a fazer algumas comparações. Em 1960, o valor positivo de F1 para a microrregião Recife era significativamente mais elevado (2,978), secundado pelas microrregiões do São Francisco $(0,409)$, Mata Seca $(0,148)$ e Mata Úmida $(0,099)$. Em 1980, segundo o que se expõe na tabela 6.10, embora Recife continue a apresentar o valor mais alto $(1,942)$, os valores das demais microrregiões que compõem a zona 
canavieira estão mais próximos: Mata Seca $(1,709)$ e Mata Úmida $(1,107)$. Pode-se inferir que, no periodo 1960/1980, o processo de modemização tenha-se propagado intensamente nas microrregiões circunvizinhas, disseminado-se mais equilibradamente, diminuindo as desigualdades da mesorregião Mata Pernambucana.

Tabela 6.10. Valores dos fatores, segundo microrregiões homogêneas, na análise fatorial em 35 variáveis. Pernambuco, 1980.

\begin{tabular}{lccc}
\hline \multicolumn{1}{c}{ MRHs } & Fator 1* & Fator 2** & Fator 3*** \\
\hline Recife & $\mathbf{1 , 9 4 2}$ & $-0,296$ & $-0,332$ \\
Mata Seca & $\mathbf{1 , 7 0 9}$ & $-0,374$ & $-0,275$ \\
Mata Úmida & $\mathbf{1 , 1 0 7}$ & $\mathbf{1 , 0 9 2}$ & $-0,423$ \\
\hline Arcoverde & $-0,899$ & $-0,119$ & $-0,552$ \\
Agreste Setentrional & $-0,421$ & $-1,378$ & $-0,297$ \\
Agreste Meridional & $-0,673$ & $-1,252$ & $-0,443$ \\
Vale do Ipojuca & $-0,507$ & $-1,280$ & $-0,401$ \\
\hline Araripina & $-0,700$ & $\mathbf{0 , 3 3 1}$ & $\mathbf{0 , 0 0 9}$ \\
Salgueiro & $-0,387$ & $\mathbf{0 , 5 8 9}$ & $\mathbf{0 , 7 6 7}$ \\
Sertão do São Francisco & $\mathbf{0 , 0 4 9}$ & $-0,105$ & $\mathbf{2 , 9 6 3}$ \\
Sertão do Moxotó & $-0,624$ & $\mathbf{1 , 6 1 6}$ & $-0,530$ \\
Alto Pajeú & $-0,595$ & $\mathbf{1 , 1 7 5}$ & $-0,484$ \\
\hline \hline
\end{tabular}

Fonte: Dados do IBGE, Censo Agropecuánio de 1980 (PE), processados através do SAS.

* Modernização; ** Subutilização da terra e pecuária extensiva; *** Irrigação e relações de trabalho nãomodernizadas

Os demais fatores mostraram-se parcialmente diferentes em relação aos obtidos na análise fatorial para 1960. O Fator 2 , em 1980, está indicando principalmente "subutilização da terra e pecuária extensiva" e seus valores positivos mais altos referemse às microrregiões: Sertão do Moxotó $(1,616)$, Alto Pajeú $(1,175)$, Mata Úmida $(1,092)$, Salgueiro $(0,589)$ e Araripina $(0,331)$. À exceção da Mata, todas as demais microrregiões pertencem à mesorregião Sertão, sabidamente tecnologicamente menos desenvolvida. Seus valores estão de fato refletindo o subaproveitamento das terras disponiveis e uma pecuária extensiva.

Já a Mata Úmida está evidenciado uma das faces da modernização, subjacente nessa dimensão: um processo produtivo calcado numa baixa relação capital/trabalho, apesar do acesso aos financiamentos. Ou seja, mais salários e menos 
insumos, segundo se depreende do exame dos escores fatoriais referentes principalmente a X18 e X19. As demais microrregiões modemizadas reveladas por F1, apresentam valores negativos para F2.

Os valores negativos mais altos de F2 referem-se a três microrregiões da Mesorregião Agreste: Agreste Setentrional (-1,378), Vale do Ipojuca $(-1,280)$ e Agreste Meridional $(-1,252)$. Tomando-se F2 como medida de subutilização da terra, a leitura dos valores negativos está assinalando o oposto. Essa indicação se coaduna com a realidade da região, onde predomina o pequeno estabelecimento, em especial o minifúndio, e a pressão demográfica é muito acentuada.

Considerando-se agora os escores apresentados por F3, que representa a dimensão "irrigação e relações de trabalho não-modernizadas", nota-se que para nenhuma microrregião da Mata ocorrem valores positivos. Recorde-se que F3, para 1960, também significava, em parte, "relações de trabalho não-modernizadas", e que para duas microrregiões da zona canavieira o fator apresentou valores positivos: Mata Seca e Mata Úmida. Então, os valores negativos do fator para 1980 estão indicando que houve perda relativa de importância desses trabalhadores, especialmente os "moradores de engenho", que foram sendo gradativamente expulsos da unidade de produção a partir dos anos 60, e substituídos crescentemente pelo trabalhador assalariado temporário.

Assim como para 1960, também para 1980, os valores de F3 são positivos para as mesmas três microrregiões localizadas na mesorregião Sertão: São Francisco (2,963), Salgueiro $(0,767)$ e Araripina (0,009). Especialmente o elevado escore do Fator 3, para o Sertão do São Francisco, deveu-se conjuntamente à utilização da irrigação, força mecânica e relações de trabalho não-modemizadas, sobretudo, a parceria.

\subsection{Conclusões}

O teste permitiu indicar a necessidade de reduzir o número total de indicadores, de modo a facilitar a etapa subseqüente, a análise dinâmica. Em outras 
palavras, essa redução conduziu à formação de estruturas mais consistentes, facilitando comparações intertemporais.

Alguns dos indicadores, inseridos propositadamente, mostraram-se redundantes, pouco acrescentando à análise. Por exemplo, despesas com adubos por área explorada (X22) e despesas com adubo por área trabalhada (X23). Em função disso, um dos dois indicadores foi descartado. Essa mesma constatação foi identificada para os indicadores: X9 (\% de estabelecimentos que usam adubos químicos) e X10 (\% dos estabelecimentos que usam adubos orgânicos); X27 (\% da área produtiva não utilizada / área aproveitável) e X28 (\% da área trabalhada / área aproveitável).

Também, lacunas derivadas da ausência de alguns indicadores foram percebidas, a título de ilustração, citam-se: área de pastagens/ área total; efetivos da pecuária (em unidade-animal) / área de pastagens e outros indicadores que poderiam contribuir para a formação da dimensão relativa à atividade pecuária.

Indicadores a exemplo dos relacionados à energia elétrica (X8), financiamentos (X1 1) e área irrigada (X30), embora válidos, foram descartados pois não havia a informação para 1950, impedindo a comparabilidade com os Censos posteriores, considerando-se a abordagem conjunta dos dados, para análise dinâmica do período 1950/80. Em outros termos, a ausência de determinadas variáveis nos Censos de 1950 e 1960 resultou em critério compulsório para o descarte de dados, apesar da importância dos mesmos evidenciada no teste.

Em suma, o teste conduziu à necessidade de refinamento das variáveis e dos indicadores. A partir desse procedimento, foi gerado novo conjunto de indicadores para a análise dinâmica. De outra parte, considerando-se a análise estática para 1995/96, tentou-se preservar os indicadores mais importantes desse novo data-set, para que fosse possivel realizar algumas inferências com a análise anterior, embora os fatores e as microrregiões não fossem exatamente os mesmos. Além disso, o conjunto de indicadores foi enriquecido, inclusive com alguns da etapa de teste, pois já não se estava mais limitado ao Censo de 1950. 
Foram extraídos, para cada análise estática (1960 e 1980), três fatores. Nas duas análises, ao primeiro fator (F1) foi atribuído o significado genérico de "modernização", por mostrar-se associado a maior parte dos indicadores desse processo. Nos dois cortes temporais, as microrregiões mais modemizadas, segundo os escores fatoriais positivos apresentados, são Recife, Mata Seca, Mata Úmida e o Sertão do São Francisco. O escore mais elevado, em 1960 e 1980, pertence à MRH Recife, respectivamente, 2,978 e 1,942. Em 1980, os escores das MRHs Recife, Mata Seca e Mata Úmida assumem valores bastante próximos $(1,942 ; 1,709 ; \mathrm{e} 1,107)$, sugerindo uma diminuição das desigualdades. As demais microrregiões evidenciaram valores negativos, significando baixo nível tecnológico, ou nível de modemização abaixo da média, considerando-se uma modernização mais ampla e consistente. Os demais fatores (F2 e F3) revelaram-se parcialmente diferentes entre os dois anos, portanto, com significados específicos, não sendo possivel efetuar uma comparação direta da posição relativa de cada MRH, segundos os respectivos escores fatoriais, entre 1960 e 1980. Cabe destacar, entretanto, o Fator 3 (irrigação e relações de trabalho não-modemizadas), referente a 1980. Nesta dimensão, o Sertão do São Francisco foi a microrregião que apresentou o escore mais elevado $(2,963)$

Embora a lista de variáveis tenha sofrido uma crítica que resultou na indicação da necessidade de supressão e inclusão de indicadores para as análises subseqüentes, o teste foi pleno de sucesso. $\mathrm{O}$ acurado trabalho manual de recomposição dos dados municipais de 1960, foi eficiente, pois as estruturas resultantes dos indicadores, assim como para os dados de 1980, mostraram-se fidedignas com a realidade evidenciada por estudos empíricos. De uma maneira geral, os resultados relativos aos dois cortes temporais conseguiram captar adequadamente o processo de modernização. Em se tratando de análises estáticas, além das principais estruturas explicativas do processo, forneceram as posições relativas das microrregiões homogêneas, a partir dos escores dessas dimensões, segundo o significado próprio a elas atribuído. 


\section{RESULTADOS E DISCUSSÃO}

\subsection{Análise dinâmica da modernização agrícola nas 12 MRHs do Estado de Pernambuco no período $1950 / 80$}

A partir da matriz $48 \times 25$ referente aos 25 indicadores de modernização observados em 12 microrregiões homogêneas em 1950, 1960, 1970 e 1980, foi calculada a matriz de correlações simples (25 x 25) entre os indicadores, com base na qual, foram identificadas 6 raizes características com valores superiores a 1 .

Com o objetivo de facilitar a análise dos resultados, tentou-se, inicialmente, utilizar apenas três fatores. Além disso, levou-se em consideração que estes tenham captado uma proporção significativa da variância total das variáveis originais: $67,47 \%$. Conforme se pode visualizar na tabela 7.1, o primeiro fator, isto é, a combinação linear das variáveis originais que pode explicar individualmente a maior parcela da variância, captou $31 \%$ da variância; o segundo, em ordem de contribuição para a variância total, captou $24 \%$, e o terceiro, cerca de $12 \%$. 
Tabela 7.1. Raizes características da matriz de correlações simples $(25 \times 25)$ para as Microrregiões Homogêneas do Estado de Pernambuco. 1950/1980.

\begin{tabular}{cccc}
\hline FATORES & RAIZ CARACTERÍSTICA & \% DA VARIÁNCIA & \% ACUMULADO \\
\hline 1 & $\mathbf{7 , 8 4 0 0}$ & 31,36 & 31,36 \\
2 & 6,0325 & 24,13 & 55,49 \\
3 & 2,9939 & 11,98 & 67,47 \\
4 & 1,9532 & 7,81 & 75,28 \\
5 & 1,1697 & 4,68 & 79,96 \\
6 & 1,1307 & 4,52 & 84,48 \\
7 & 0,8441 & 3,38 & 87,86 \\
8 & 0,6827 & 2,73 & 90,59 \\
9 & 0,5540 & 2,22 & 92,80 \\
10 & 0,4863 & 1,87 & 94,68 \\
11 & 0,3150 & 1,26 & 95,94 \\
12 & 0,2319 & 0,93 & 96,86 \\
13 & 0,1949 & 0,78 & 97,64 \\
14 & 0,1673 & 0,67 & 98,31 \\
15 & 0,1052 & 0,42 & 98,73 \\
16 & 0,1005 & 0,40 & 99,14 \\
17 & 0,0669 & 0,27 & 99,40 \\
18 & 0,0508 & 0,20 & 99,61 \\
19 & 0,0415 & 0,17 & 99,77 \\
20 & 0,0282 & 0,11 & 99,89 \\
21 & 0,0163 & 0,07 & 99,95 \\
22 & 0,0087 & 0,03 & 99,99 \\
23 & 0,0026 & 0,01 & 100,00 \\
24 & 0,0010 & 0,00 & 100.00 \\
25 & 0,0000 & 0,00 & 100,00 \\
Total & $25 *$ & 100 & 100 \\
\hline
\end{tabular}

Fonte: Dados da pesquisa oblidos através do SAS.

* ordem da matriz

O passo seguinte foi o de confirmar se essa quantidade inicial de fatores seria adequada para explicar ou captar conjuntamente proporção significativa da variância de cada variável ou, pelo menos, que a maior parte das variáveis estivesse associada fortemente a algum dos três fatores. Essa investigação foi procedida analisando-se as comunalidades e as cargas fatoriais.

Avaliou-se, então, a capacidade explicativa dos três fatores em conjunto em relação à cada variável. Isto pode ser visto pelos valores das comunalidades listadas na tabela 7.2. Observa-se que dos 25 indicadores, os três fatores explicariam grande parte 
da variância total de pelo menos 22 . Outros três indicadores não estão bem captados, apresentando comunalidade inferior a 50\%: X12 (percentagem das despesas com adubos, corretivos, sementes, mudas e defensivos agricolas / despesa total), X14 (percentagem da área com pastagens plantadas / área total de pastagens) e X16 (número de litros de leite / vacas ordenhadas), respectivamente, $0,106,0,321$ e 0,457 .

Tabela 7.2. Coeficientes de correlação (cargas fatoriais), comunalidades e percentagem da variância explicada por cada fator após a rotação pelo método Varimax, na extração de três fatores em 25 indicadores. Microrregiões Homogêneas do Estado de Pernambuco, 1950 a 1980.

\begin{tabular}{|c|c|c|c|c|}
\hline \multirow{2}{*}{ Indicadores de modernização } & \multicolumn{3}{|c|}{ Coeficiente de Correlação } & \multirow{2}{*}{ Comunalidade } \\
\hline & Fator 1 & Fator 2 & Fator 3 & \\
\hline $\mathrm{Xl}$ = perostagem dos estabelecimentos que usam forfa mecânica & 0,077 & 0,794 & $-0,118$ & 0,651 \\
\hline \2 = proentagem dos estabelocimartos que usam forca animal & 0,034 & $\mathbf{0 , 9 0 7}$ & $-0,151$ & 0,846 \\
\hline 13 = poromtagam dos esabelocimentos que usam força humana* & $-0,026$ & $-0,950$ & 0,158 & 0,928 \\
\hline $.44=$ númuro de tratores / área trabalhada & $\mathbf{0 , 7 7 4}$ & 0,217 & $-0,342$ & 0,763 \\
\hline X5 = nümoro de ratores / equivalonte-homem & $\mathbf{0 , 7 5 4}$ & 0,286 & $-0,273$ & 0,725 \\
\hline I6 = nưmoro de arados de traçào mecànica / área trabalhada & 0,826 & 0,202 & $-0,226$ & 0,773 \\
\hline .17 = numero de arados de traçào animal / área trabalhada & $-0,089$ & 0,895 & $-0,210$ & 0,835 \\
\hline X8 = número de arados de tração móánica e animal / EH & $-0,020$ & 0,923 & $-0,171$ & 0,881 \\
\hline$\lambda 9=0$ o do valor dos bens (exato terras e culturas)/valor total dos bens & $-0,594$ & 0,458 & $-0,011$ & 0,563 \\
\hline $\mathrm{X} 10=\mathrm{o}_{\mathrm{o}}$ do valor de máq. e instrumertos agrários / valor total dos bens & 0,584 & $-0,042$ & 0,431 & 0,528 \\
\hline $\begin{array}{l}\text { X11 }=\text { promtagem das dexpasas com salários } / \text { depeca total } \\
\text { X12 }=\% \text { o de despesas com adubos, corretivos, sementes, mudas e }\end{array}$ & 0,337 & $-0,249$ & 0,578 & 0,510 \\
\hline defensivos / dexpesa total & 0,322 & 0,048 & 0,002 & 0,106 \\
\hline X13 = perontagem da ȧrea corn pastagens / àrea explorada & $-0,749$ & 0,035 & $-0,298$ & 0,651 \\
\hline $\mathrm{X} 14$ = $\%$ da área com pastagens plantadas / área total de pastagans & 0,113 & 0,287 & $-0,476$ & 0,321 \\
\hline X15 = unidade-gado $/$ área de pastagans & 0,689 & $-0,220$ & 0,024 & 0,523 \\
\hline X16 = número de litros de leite / vacas ordenhadas & 0,493 & 0,117 & $-0,448$ & 0,457 \\
\hline A17 = $\%$ da área de lavouras / área explorada & 0,811 & $-0,222$ & $-0,379$ & 0,851 \\
\hline X18 = 0 da área de collheita da cana-dosçucar / área traballhada & 0,929 & $-0,089$ & 0,017 & 0,871 \\
\hline X19 = o da área de collheita do feijão / área trabalhada & $-0,591$ & $-0,409$ & $-0,224$ & 0,567 \\
\hline \multicolumn{5}{|l|}{$\mathrm{X} 20=0$ da area com matas naturais + terras produtivas } \\
\hline não-nilizadas / ärea aproveitável & $-0,073$ & 0,017 & $\mathbf{0 , 8 8 2}$ & 0,784 \\
\hline \21 = total de pasoal coupado (EH) / área explorada & 0,355 & $-0,481$ & $-0,568$ & 0,680 \\
\hline X22 = \% de empregados temporírios / total do pessoal oapado (EH) & 0,490 & $-0,296$ & 0,625 & 0,718 \\
\hline$\sqrt{23}=\%$ de empregados pamanented total do pessoal ocupado (EH) & $\mathbf{0 , 8 7 0}$ & $-0,073$ & 0,087 & 0,769 \\
\hline \24 = $\%$ de mãodoobra faniliar / total do pessoal ocipado em (EH) & $-0,810$ & 0,236 & $-0,449$ & 0,912 \\
\hline$\times 25=0$ de parceiros e ourro condição/ total do pessoal capado (E.H) & $-0,200$ & $-0,356$ & $\mathbf{0 , 7 2 5}$ & 0,652 \\
\hline Perontagem da variância explicada pelo fator após a rotação & 30,88 & 21,25 & 15,34 & \\
\hline
\end{tabular}

Fonte: Dados do IBGE, Censos Agricolas de 1950 e 1960 e Censos Agropeavirios de 1970 e 1980 (PE), procescados aravés do SAS. * estabelecimantos com uso exclusivo de força humana vou sern dectaração de uso de força animal ou mecánica. 
Observa-se, também, que os indicadores X12, X14 e X16 não estão associados fortemente a nenhum dos três fatores, considerando-se cargas fatoriais superiores a 0,5 .

Note-se, por outro lado, que para X9 (percentagem do valor dos bens (exceto terras e culturas) / valor total dos bens), X10 (percentagem do valor das máquinas e instrumentos agrários / valor total dos bens), X11 (percentagem das despesas com salários / despesa total) e X19 (percentagem da área de colheita do feijão / área trabalhada), as respectivas comunalidades possuem valor em torno de 0,54 , indicando que os três fatores em conjunto explicariam moderadamente a variância desses indicadores.

Em função das baixas comunalidades apresentadas pelo conjunto dos três fatores para X12, X14 e X16, procedeu-se em nivel de teste a uma análise fatorial extraindo-se quatro fatores. Como resultado, constatou-se que após a rotação, para X12 e, principalmente, para X14, ainda ocorria comunalidade de valor baixo: 0,49 e 0,36, respectivamente. Para X16, a comunalidade passou de baixa, a um valor moderado: 0,53. Em suma, a adição do Fator 4 não foi suficiente, para no conjunto dos quatro fatores, elevar significativamente as comunalidades. Além disso, o Fator 4 não se mostrou associado fortemente a nenhuma das três variáveis mencionadas (X12, X14 e X16). Não obstante, há que se considerar que o Fator 4 apresentou-se forte e positivamente associado a X11 (salários), X20 (terras ociosas), X22 (empregados temporários) e X25 (parceiros e agregados) e associado forte e negativamente a X24 (trabalho familiar).

Além disso, a extração de quatro fatores acarretou forte e positiva associação do Fator 3 com X12 $(0,658)$ e, identicamente, do Fator 2 com X16 $(0,602)$. O problema continuou a persistir apenas para X14: a comunalidade manteve-se baixa e, além disso, nenhum dos quatro fatores apresentou correlação forte ou moderada com esse indicador.

Na seqüência de testes, foram extraidos cinco fatores. Como resultado. apenas para X14 ainda ocorria comunalidade de baixo valor: 0,36. 
Excetuando $\mathrm{X} 14$, todos os demais indicadores revelaram-se associados forte ou moderadamente aos fatores. Especificamente, ao Fator 5, mostrou-se forte e positivamente correlacionado X12 (despesas com insumos) e forte e negativamente associado X15 (densidade da pecuária).

Procedendo-se a análise fatorial extraindo-se seis fatores, justamente o total associado às raizes caracteristicas maiores que a unidade, observou-se nos dados rotacionados, que todas as comunalidades, à exceção de X14, são elevadas, indicando que apenas seis fatores são adequados para captar parcelas expressivas da variância de praticamente quase todos os 25 indicadores. Ao Fator 6, associa-se forte e positivamente X12 (despesas com insumos), e forte e negativamente, X15 (densidade da pecuária). Ao contrário de todos os demais indicadores, X14 continuou a apresentar associação fraca com os fatores.

Em suma, o acréscimo sucessivo de fatores, embora continuamente eleve o valor das comunalidades, não aumentou significativamente a capacidade explicativa dos fatores com relação ao indicador X14. Entretanto, a análise fatorial com a extração de quatro fatores mostrou-se mais eficiente, pois vai acrescentar à análise os indicadores X12, X14 e X16, os quais, na extração de três fatores não estavam associados fortemente a nenhuma variável. $\mathrm{O}$ resultado final foi a elevação do valor das comunalidades e a captação da variância das variáveis originais ascendeu de $67 \%$ (3 fatores) para $75 \%$ (4 fatores).

Optou-se por efetuar a análise fatorial com a extração de quatro fatores: por um lado, para facilitar a interpretação dos dados, por outro, pelo fato de considerarse que a adição de mais fatores pouco acrescentaria à análise do fenômeno modernização. Além disso, fatores adicionais passam a explicar, tomados isoladamente, proporções cada vez menores da variância dos indicadores originais ${ }^{20}$. Levou-se também em consideração um critério mais empírico que foi o de reter determinada quantidade de fatores, que após a rotação, pudesse ser interpretável de modo coerente.

\footnotetext{
${ }^{20} \mathrm{Na}$ análise fatorial extraindo-se seis fatores, a proporção da variância explicada por esse conjunto de fatores é de 84\%. Porém a variância explicada por cada fator dectesce sucessivamente. Fator $1(19,66 \%)$, Fator 2 ( $16,11 \%)$, Fator $3(15,89 \%)$, Fator $4(15,35 \%)$, Fator $5(10,62 \%)$ e Fator $6(6,83 \%)$.
} 
Objetivando-se melhorar a leitura e a interpretação dos quatro fatores, foi feita a rotação através do método Varimax.

Note-se que o total da variância explicada pelos quatro fatores, em conjunto, continua o mesmo, antes e após a rotação $(75,28 \%$ ), como pode ser observado na tabela 7.3.

Tabela 7.3. Percentagem da variância explicada por cada fator antes e após a rotação ortogonal.

\begin{tabular}{lcc}
\hline Fatores & Antes da rotação (\%) & Após a rotação (\%) \\
\hline Fator 1 & 31,36 & 20,22 \\
Fator 2 & 24,13 & 19,54 \\
Fator 3 & 11,98 & 19,06 \\
Fator 4 & 7,81 & 16,46 \\
Total & 75,28 & 75,28 \\
\hline
\end{tabular}

Fonte: Dados da pesquisa obtidos através do SAS.

Os fatores F1 e F2 passaram a captar uma proporção menor da variância total das variáveis originais. Entretanto, o poder explicativo do Fator 3 e do Fator 4 aumentou sensivelmente, conforme pode ser visualizado na tabela 7.3.

A tabela 7.4 apresenta os resultados da análise fatorial de 25 indicadores observados nas 12 microrregiões homogêneas de Pernambuco, para os quatro cortes temporais - 1950, 19601970 e 1980 - relativos à extração de quatro fatores: os coeficientes de correlação entre cada fator e cada indicador, as comunalidades, e a proporção da variância das variáveis originais explicada por cada um dos quatro fatores, após a rotação. 
Tabela 7.4. Coeficientes de correlação (cargas fatoriais), comunalidades e percentagem da variância explicada por cada fator após a rotação pelo método Varimax, na extração de quatro fatores em 25 indicadores. Microrregiões Homogêneas do Estado de Pernambuco, 1950 a 1980.

\begin{tabular}{|c|c|c|c|c|c|}
\hline \multirow{2}{*}{ Indicadores de modernização } & \multicolumn{4}{|c|}{ Coeficiente de Correlação } & \multirow{2}{*}{ Comunalidade } \\
\hline & Fator 1 & Fator 2 & Fator 3 & Fator 4 & \\
\hline $\mathrm{Xl}=\%$ estabelocimantos que usam força mocinica & $\mathbf{0 , 7 0 0}$ & $-0,247$ & 0,340 & $-0,130$ & 0,683 \\
\hline $\mathrm{X}_{2}=0$, estabelocimentos que usam força aninal & 0,966 & 0,007 & $-0,003$ & $-0,097$ & 0,942 \\
\hline $\mathrm{X} 3=\%$ estabelaimontos que usam força humana $*$ & -0948 & 0,118 & $-0,122$ & 0,133 & 0,945 \\
\hline $\mathrm{X} 4$ = número de tratores / àrea trabalhada & 0.147 & 0,323 & $\mathbf{0 , 8 6 2}$ & $-0,187$ & 0,903 \\
\hline is = núnaro de tratores equivalante- homem & 0.215 & 0,288 & $\mathbf{0 , 8 3 7}$ & $-0,123$ & 0,844 \\
\hline X6 = número de arados de tuação mọanica $/$ àrea trabalhada & 0,138 & 0,348 & 0,864 & $-0,058$ & 0,891 \\
\hline $\mathrm{X7}$ = número de arados de tração aninal / área trabalhada & 0,913 & $-0,048$ & $-0,092$ & $-0,183$ & 0.935 \\
\hline $\begin{array}{l}\mathrm{X} 8=\text { número de arados de tração mocânica e animal } / \mathrm{EH} \\
\mathrm{X} 9=\% \text { do valor dos bens (excato tarras e culturas) }\end{array}$ & 0,970 & $-0,044$ & $-0,017$ & $-0,134$ & 0,961 \\
\hline $\begin{array}{l}\text { valor total dos bons } \\
\mathrm{X} 10=\% \text { do valor de maq. e instumentos agrários }\end{array}$ & 0,251 & $-0,801$ & $-0,014$ & -0.240 & 0,762 \\
\hline valor total dos bens & $-0,098$ & 0,153 & 0,505 & 0,530 & 0,569 \\
\hline $\begin{array}{l}\mathrm{X} 11=\% \text { das dexpesas com salärios } / \text { dexpesa total } \\
\mathrm{X} 12=\% \text { de dexpesas com adubos, comtjivos, }\end{array}$ & -0.140 & 0,335 & $-0,085$ & 0,693 & 0.619 \\
\hline semantes, mudas e dofensivos / depasa total & $-0,139$ & $-0,183$ & 0,658 & -0.012 & 0,486 \\
\hline $\mathrm{X} 13=\% \mathrm{da}$ àrea com pastagens $/$ area explorada & $-0,094$ & $-0,618$ & -0.279 & $-0,526$ & 0.745 \\
\hline X14 = $\%$ da área c/ pastagans plantadas / área de pastagens & 0,367 & 0,252 & 0,036 & $-0,397$ & 0.358 \\
\hline X15 = unidade-gado / área de pastagens & -0.044 & $\mathbf{0 , 7 5 2}$ & 0,172 & 0.263 & 0.666 \\
\hline X16 = numaro de litros de leite / vacas ordonhadas & 0,257 & 0,602 & 0,204 & $-0,257$ & 0,534 \\
\hline X17 = \% da ánea de lavouras / área explorada & -0.072 & 0,842 & $\mathbf{0 , 4 0 5}$ & -0.117 & 0,892 \\
\hline X18 = o da area de coltheita da cana-do açicar / area trabalhada & -0.057 & 0,592 & 0,681 & 0,245 & 0,877 \\
\hline $\begin{array}{l}\mathrm{X} 19=\% \text { da área de collheita do feijāo } / \text { area trabalhada } \\
\mathrm{X} 20=\% \text { da área com matas naturais + taras produtivas }\end{array}$ & $-0,373$ & $-0,155$ & $-0,543$ & $-0,346$ & 0,577 \\
\hline não-ưilizadas / ánes aprovectável & $-0,003$ & $-0,235$ & $-0,190$ & 0,840 & 0.797 \\
\hline$\lambda 21$ = total de pessoal ocupado (EH) / area explorada & $-0,302$ & 0,719 & $-0,009$ & -0.398 & 0.767 \\
\hline $\mathrm{X} 22=\%$ de empregados tariporános / passoal coupado (EH) & $-0,305$ & 0,196 & 0,275 & 0,717 & 0,721 \\
\hline X23 = \% de empregados permanentes/pessoal coupado (EH) & $-0,007$ & 0,610 & $\mathbf{0 , 5 4 7}$ & 0,317 & 0,772 \\
\hline X24 = 90 de mão dzabra familiar / passoal ocupado (EH) & 0,196 & $-0,490$ & $-0,471$ & $-0,612$ & 0,913 \\
\hline X25 = \% de parceiros e outra condiçãol pessoal ocupado (EH) & $-0,353$ & $-0,074$ & $-0,189$ & 0,702 & 0,658 \\
\hline \% da variância explicada pelo fator após a rotação....................... & 20,22 & 19,54 & 19,06 & 16.46 & \\
\hline
\end{tabular}

Fonte: Dados do IBGE, Consos Agricolas de 1950 e 1960 e Consos Agropouários de 1970 e 1980 (PE), provessdos através do SAS. * estabelecimontos com uso exclusivo de força humana e/ou sern declaração de uso de força animal ou mecainica.

Tomando-se os dados da tabela 7.4, classificou-se os coeficientes de correlação ou cargas fatoriais em 6 grupos ou intervalos de valores absolutos (tabela 7.5). O Fator 1 apresenta correlações positivas, numa escala que vai de forte, moderada, e fraca, com $44 \%$ dos indicadores de modernização, mas imperam com maior frequência a correlações positivas e fracas, englobando $28 \%$ do total dos 25 indicadores. No conjunto, prevalecem as correlações negativas (56\%), principalmente fracas $(52 \%)$. 
O Fator 2 é o que apresenta maior percentual de correlações positivas (60\%), prevalecendo as correlações fracas com grande parte dos indicadores (36\%). As correlações negativas totalizam $40 \%$, também prevalecendo as correlações fracas.

Semelhantemente ao Fator 1 e opostamente ao Fator 2, o terceiro fator apresenta principalmente correlações positivas (52\%), preponderando as fracas (24\%). Entre as correlações negativas, prevalecem também as fracas (44\%).

Entre todos os fatores, o Fator 4 é o que apresenta o maior percentual de associações negativas (64\%), em especial as fracas (56\%). Entre as correlações positivas, $16 \%$ são fracas, $16 \%$ foram classificadas como fortes, e as restantes (4\%), como moderadas.

Tabela 7.5. Percentagem de grupos de variáveis segundo o grau de correlação entre cada fator e a variável.

\begin{tabular}{|c|c|c|c|c|c|}
\hline $\begin{array}{c}\text { Grau de Correlação } \\
\text { do Fator }\end{array}$ & $\begin{array}{c}\text { Intervalo } \\
\text { (valores absolutos) }\end{array}$ & $\begin{array}{c}\text { Fator } 1 \\
(\%)\end{array}$ & $\begin{array}{c}\text { Fator } 2 \\
(\%)\end{array}$ & $\begin{array}{c}\text { Fator } 3 \\
(\%)\end{array}$ & $\begin{array}{r}\text { Fator } 4 \\
(\%)\end{array}$ \\
\hline positivo e forte & (0,6 e mais) & 16,00 & 20,00 & 20,00 & 16,00 \\
\hline positivo e moderado & $(0,5$ a menos de 0,6$)$ & 0 & 4,00 & 8,00 & 4,00 \\
\hline positivo e fraco & (menos de 0,5) & 28,00 & 36,00 & 24,00 & 16,00 \\
\hline negativo e forte & (0,6 e mais) & 4,00 & 8,00 & 0 & 4,00 \\
\hline negativo e moderado & $(0,5$ a menos de 0,6$)$ & 0 & 0 & 4,00 & 4,00 \\
\hline negativo e fraco & (menos de 0,5 ) & 52,00 & 32,00 & 44,00 & 56,00 \\
\hline Total & & 100,00 & 100,00 & 100,00 & 100,00 \\
\hline
\end{tabular}

Fonte: Classificação elaborada pela pesquisa a partir dos dados processados através do SAS.

De uma maneira geral, o objetivo da rotação foi alcançado com sucesso pois as correlações, para os quatro fatores, revelaram-se em cada caso, com maior freqüência, relativamente fortes e relativamente fracas. Para todos os fatores prevalecem as correlações fracas, positivas ou, principalmente, negativas. Em consequência, as 
correlações positivas fortes indicarão bem acentuadamente, em seu conjunto, o significado de cada fator. Para nenhum fator houve a prevalência de correlações de valores moderados, isto é, nem fracas nem fortes.

A análise das cargas fatoriais a seguir, de acordo com os dados apresentados na tabela 7.4, fornecerá uma interpretação específica de cada fator.

Considerando-se a análise fatorial na extração de quatro fatores tem-se que o primeiro fator (F1) está forte e positivamente correlacionado com $\mathrm{X} 7$ (número de arados de tração animal / área trabalhada). Apesar de fraca, apresenta também uma correlação positiva com X4 (número de tratores / área trabalhada) e X6 (número de arados de tração mecânica/ área trabalhada). Paralelamente, revela correlações negativas e fracas com X10 (\% do valor de máquinas e instrumentos agrários / valor total dos bens) e X12 (\% de despesas com adubos, corretivos, sementes, mudas e inseticidas / despesa total). A leitura desse conjunto de indicadores sugere que Fl esteja medindo a intensidade da exploração da terra, muito mais pelo lado da incorporação de tração animal, do que mecânica, com exclusão das inovações químico-biológicas.

Por outro lado, o Fator 1 está positiva e fortemente associado aos indicadores: X1 (percentagem dos estabelecimentos que usam força mecânica); X2 (percentagem dos estabelecimentos que usam força animal); X8 (número de arados de tração animal e mecânica / equivalente-homem). Está ainda positiva, mas fracamente, associado a X5 (número de tratores / equivalente-homem). Esses indicadores revelam que F1 também está medindo o crescimento da relação capital/trabalho, no que se refere à incorporação, particularmente da tração animal. A forte correlação com o indicador X1 (estabelecimentos declarantes de uso de força mecânica) e a fraca associação com X4 (tratores) e X6 (arados de tração mecânica), está dizendo que, embora a mecanização seja relativamente difusa entre o conjunto de estabelecimentos, não há intensidade, ou seja, está bem aquém das necessidades da exploração.

De outra parte, ressalte-se que o indicador X8 deve ser lido com cautela, pois está representando muito mais os arados de tração animal. A esse respeito observese que em 1995, segundo dados do IBGE, predominavam ainda os arados de tração 
animal no estado. Somente na microrregião canavieira Mata Seca, os arados de tração mecânica eram os mais frequentes.

Embora fracas, há que se mencionar também as correlações positivas com X14 (\% de pastagens plantadas / área explorada) e X16 (número de litros de leite / vacas ordenhadas). Esses indicadores estariam revelando estabelecimentos com pecuária de corte e de leite menos extensiva. Apresenta também associação positiva, mas fraca, com X24 (trabalho familiar) e X9 (\% do valor dos bens (exceto terras e culturas) / valor total dos bens), este último indicando áreas onde as terras não são o principal bem.

O Fator 1 está ainda negativa e fortemente associado aos estabelecimentos com utilização de força humana e/ou sem declaração de uso de força animal ou mecânica (X3), e fraca e negativamente ao trabalho assalariado, permanente ou temporário, e de agregados e moradores. Portanto, o Fator 1 não está indicando qualquer modemização das relações sociais de produção, em face da oposição ao trabalho assalariado e da associação positiva ao trabalho familiar.

O Fator 1 está expressando fortemente a dimensão representativa do uso de tração animal, tanto em termos de difusão, como em intensidade. Esse fator está mais associado às áreas de pecuária menos extensiva $(\mathrm{X} 14=0,367)$, do que às lavouras $(\mathrm{X} 17$ $=-0,072$ ) ou a própria pecuária de uma maneira geral (X13). Contém relativa dualidade tecnológica, pois, apesar de representar a utilização de força animal, está fortemente associado ao indicador que expressa a utilização de força mecânica (X1) e fracamente aos indicadores de uso de trator. Associa-se negativamente à maioria dos indicadores restantes. Em resumo, essa dimensão, apesar da dualidade tecnológica, representa mais os estabelecimentos com preponderância de uso de tração animal e relativamente associados ao trabalho familiar. Revela-se parcialmente semelhante ao Fator 3, denominado de "produção familiar com uso de tração animal" (Hoffinann \& Kassouf, 1989, p. 279); ao Fator 3 (produção familiar) identificado por Figueiredo (1996, p. 90); e ao Fator 5 (padrão elementar de modernização da agricultura), que apresenta em sua composição indicadores como emprego do arado e da força animal (Mesquita et al., 1977, p.26). 
Em síntese, o Fator 1 será interpretado como medida de evolução da tração animal , com inclusão da mão-de-obra familiar, e relativa difusão, sem aspectos de intensidade da mecanização. Trata-se de modemização bastante incipiente e parcial, defasada no tempo; revela também forte dualidade tecnológica, pois indica difusão de forças mecânica, paralelamente a difusão de força animal, sendo que esta apresenta simultaneamente o indicador de intensidade, ao contrário da primeira.

O Fator 2 está associado forte e positivamente com: X15 (unidade-gado / área de pastagens), X16 (número de litros de leite / vacas ordenhadas), X17 (percentagem da área de lavouras / área explorada), X23 (percentagem de empregados permanentes/ total do pessoal ocupado), X21 (total de pessoal ocupado (EH) / área explorada). Assinale-se que esse último indicador está revelando áreas onde existe uso intensivo de mão-de-obra, e na qual subjaze uma subestrutura bastante específica marcada pela exclusão do trabalho familiar: considere-se a esse respeito a correlação negativa de X24 (\% de mão-de-obra familiar / pessoal ocupado). F2 também está associado positiva e moderadamente com X18 (percentagem da área de colheita da canade-açúcar / área trabalhada). Apresenta, ainda, correlação positiva, mas fraca, com X14 (\% da área com pastagens plantadas / área de pastagens).

Esse fator está forte e negativamente associado à percentagem do valor dos bens (exceto terras) no valor total ( X9), indicando áreas de forte valorização das terras; e a X13 (percentagem de área de pastagens/ área explorada).

$\mathrm{Na}$ dimensão representada pelo Fator 2, pode-se identificar duas subestruturas: uma mais geral, revelando a pecuária mais intensiva, com ênfase na atividade leiteira; outra, associando pecuária melhorada a áreas de lavouras, principalmente a cana-de-açúcar, onde a terra é o principal bem, dado seu alto valor. Genericamente, F2 será denominado "pecuária melhorada", em áreas onde as lavouras têm mais expressividade.

O Fator 3 revela-se forte e positivamente correlacionado com: X4 (número de tratores / área trabalhada), X5 (número de tratores / equivalente- homem), X6 (número de arados de tração mecânica / área trabalhada) e X12 (percentagem de 
despesas com adubos, corretivos, sementes, mudas e inseticidas / despesa total). Associase, também, positiva, mas moderadamente, a X10 (percentagem do valor de máquinas e instrumentos agrários / valor total dos bens). Esses indicadores estão revelando simultaneamente intensidade da exploração e aumento da relação capital-trabalho.

Considere-se, também, que F3 está positiva e moderadamente associado à cana-de-açúcar (X18), e negativa e fracamente à lavoura do feijão (X19). Apresenta, ainda, correlação moderada e positiva com o trabalho assalariado permanente (X23). Revela, por outro lado, antagonismo em relação ao trabalho familiar $(\mathrm{X} 24=-0,471)$. Aproxima-se de sistemas agricolas $(X 17=0,405)$ e opõe-se ao da pecuária $(X 13=$ 0,279). Entre os quatro fatores, é o que melhor expressa a modernização. Esse fator será denominado mecanização, apresentando uma subestrutura com ênfase na cana-de açúcar.

O Fator 4 está negativamente associado a cerca de $64 \%$ dos indicadores. Mostrou-se forte e positivamente associado a X11 (\% das despesas com salários / despesa total), X20 (\% da área com matas naturais + terras produtivas não-utilizadas / área aproveitável), X22 (\% de empregados temporários / pessoal ocupado), X25 (\% de parceiros e outra condição / pessoal ocupado). Associa-se, forte e negativamente, ao trabalho familiar (X24) e negativa e moderadamente à participação das pastagens na área explorada (X13).

Observe-se que, embora associado positiva e moderadamente ao valor de máquinas e instrumentos agrários (X10), está associado negativamente a todos os indicadores de utilização das forças mecânica e animal (X1, X2, X4, X5, X6, X7 e X8), e positiva e fracamente ao conjunto de estabelecimentos declarantes do uso exclusivo de força humana e/ou não declarantes do uso de força animal ou mecânica (X3). A associação forte e positiva com o indicador de despesas com salários $(X 11=0,693)$ e a negativa, apesar de fraca associação com as despesas referentes aos insumos químicobiológicos necessários à produção $(\mathrm{X} 12=-0,012)$, revelam um setor da produção onde se reúnem estabelecimentos cujos maiores gastos são com pessoal. Isto poderia ser interpretado como existência de escassa modernização, que está sendo medida por esse fator, ou baixa relação capital-trabalho. 
Paralelamente, há evidências de uma pecuária leiteira extensiva, dada a correlação negativa entre o fator e X16 (número de litros de leite / vacas ordenhadas) e X14 (percentagem da área de pastagens plantadas sobre a área total de pastagens). Entretanto, o Fator 4 está associado positiva e fracamente ao indicador X15, de densidade da pecuária (unidade-gado / área de pastagens). Ou seja, há margem para se supor que essa estrutura esteja abrigando parcela da pecuária menos extensiva, com exceção da leiteira.

Acrescente-se que a dimensão representada por esse quarto fator não está ligada, em modo geral, nem à agricultura $(\mathrm{X} 17=-0,117)$, nem à pecuária $(X 13=-0,526)$. Entretanto, tem mais relação com a cultura canavieira $(X 18=0,245)$ do que com a tradicional e familiar cultura do feijão $(X 19=-0,346)$.

A correlações positivas e fortes com os indicadores "parceiros e trabalhadores de outra condição" (X25), despesas com salários (X11) e proporção de empregados assalariados (X22), fazem supor que existam explorações com o emprego conjunto de diferentes relações de trabalho. Chama também atenção o indicador X20 (percentagem da área com matas naturais e terras produtivas não utilizadas / área aproveitável), que apresenta correlação positiva e forte. Ou seja, existe um subaproveitamento do recurso terra. O Fator 4 será denominado de "assalariamento, relações de trabalho não-modernizadas e subutilização do recurso terra", sendo interpretado como uma medida de atraso.

Através da tabela 7.6, apresentam-se os valores do Fator 1 para as 12 microrregiões homogêneas de Pernambuco, nos quatro cortes temporais: 1950, 1960, 1970 e 1980. O Fator 1, está expressando principalmente a utilização da tração animal, conforme análise anterior das cargas fatoriais. 
Tabela 7.6. Valores do Fator 1 (ração animal), segundo microrregiões homogêneas, na análise fatorial em 25 indicadores. Pernambuco, 1950 a 1980.

\begin{tabular}{lcccc}
\hline \hline Microrregião Homogênea & $\mathbf{1 9 5 0}$ & $\mathbf{1 9 6 0}$ & $\mathbf{1 9 7 0}$ & $\mathbf{1 9 8 0}$ \\
\hline Recife & $\mathbf{0 , 5 3 1}$ & $\mathbf{0 , 0 7 7}$ & $\mathbf{0 , 0 5 1}$ & $-0,072$ \\
Mata Seca & $-0,002$ & $-0,285$ & $-0,234$ & $-0,232$ \\
Mata Úmida & $-0,177$ & $-0,324$ & $\mathbf{0 , 0 1 5}$ & $-0,152$ \\
\hline Arcoverde & $-0,417$ & $-0,366$ & $\mathbf{1 , 2 8 4}$ & $\mathbf{3 , 1 0 8}$ \\
Agreste Setentrional & $-1,148$ & $-1,236$ & $-1,050$ & $-0,583$ \\
Agreste Meridional & $-0,658$ & $-0,810$ & $\mathbf{0 , 4 6 9}$ & $\mathbf{1 , 7 5 5}$ \\
Vale do Ipojuca & $-0,740$ & $-0,909$ & $-0,358$ & $\mathbf{0 , 7 2 8}$ \\
\hline Araripina & $-0,577$ & $-0,816$ & $-0,555$ & $\mathbf{0 , 7 9 9}$ \\
Salgueiro & $-0,294$ & $-0,579$ & $-0,435$ & $\mathbf{1 , 2 7 7}$ \\
Sertão do São Francisco & $-0,790$ & $-1,255$ & $-0,307$ & $\mathbf{1 , 2 5 7}$ \\
Sertão do Moxotó & $-0,212$ & $-0,491$ & $\mathbf{0 , 1 5 3}$ & $\mathbf{2 , 8 8 3}$ \\
Alto Pajeú & $-0,494$ & $-0,674$ & $\mathbf{0 , 2 8 3}$ & $\mathbf{2 , 5 6 3}$ \\
\hline \hline
\end{tabular}

Fonte: Dados do IBGE, Censos Agrícolas de 1950 e 1960 e Censos Agropecuários de 1970 e 1980 (PE), processados através do SAS.

Para 1950, os valores do Fator 1 são todos negativos, à exceção da microrregião Recife $(0,531)$. Quer dizer, para as demais os escores estavam posicionados abaixo da média. Afora a força humana, a principal força utilizada à época era a tração animal e as regiões mais adiantadas tecnologicamente exibiam esse padrão. Observa-se que, em 1950, os dois valores negativos mais próximos da média correspondiam a duas microrregiões da zona canavieira: Mata Seca $(-0,002)$ e Mata Úmida $(-0,177)$. Portanto, a segunda MRH melhor posicionada era a Mata Seca.

Em 1960, o quadro mantém-se aparentemente o mesmo: somente para a MRH Recife o escore fatorial tem valor positivo, embora menor $(0,077)$ que o anterior, indicando afastamento. Em 1970, esse quadro se altera: na zona canavieira, apenas a Mata Seca continua a apresentar valor negativo $(-0,234)$, enquanto que Recife e Mata 
Úmida exibem valores positivos, próximos de zero, ou seja, em torno da média. O maior valor positivo é apresentado pela microrregião agrestina Arcoverde $(1,284)$, seguida pelo Agreste Meridional $(0,469)$, e pelas microrregiões sertanejas Alto Pajeú $(0,283)$ e Sertão do Moxotó $(0,153)$.

Em 1980, todas as microrregiões canavieiras passam a apresentar valores negativos de F1. Opostamente, na mesorregião Agreste - exceto a microrregião Agreste Setentrional - e no Sertão, todas as microrregiões apresentam valores positivos e bastante expressivos. À primeira vista, ocorreu entre 1950 e 1980, na zona canavieira, o relativo afastamento da utilização da tração animal, em favor de um padrão de modemização mais consistente. Nas demais, ao contrário, houve uma evolução bastante positiva e crescente desse tipo de força, associada, possivelmente, a um padrão elementar de tecnificação vinculado à produção familiar.

Com o intuito de verificar as alterações relacionadas ao Fator 1, principalmente ao seu principal significado, qual seja a utilização de força animal, calculou-se a variação ${ }^{21}$ dos escores fatoriais para as microrregiões, no periodo 1950/1980 e nos subperíodos 1950/60, 1960/70 e 1970/80 (tabela 7.7). A variação do valor do fator entre cada corte temporal estará exprimindo a velocidade do processo, segundo cada unidade de observação.

De modo geral, a Zona da Mata é a que apresenta maior afastamento, em termos de tendência, desse tipo de força. No periodo 1950/80, a variação é negativa para Recife $(-0,603)$ e Mata Seca $(-0,230)$. Na Mata Úmida $(0,025)$, a variação positiva próxima de zero indica um quadro relativamente estável.

Nas mesorregiões Agreste e Sertão, observa-se a expansão da utilização da tração animal, comprovada pelas altas variações positivas dos valores do fator, nos subperíodos 1960/70 e 1970/80, expressando a tendência, grosso modo, de crescimento

\footnotetext{
${ }^{21}$ Sejam $\mathrm{Fl}$ (to) os valores do Fator 1 no periodo inicial to, e Fl (tl) os valores do Fator no ano $\mathrm{tl}$. Chamaremos de $\Delta F 1$ as variações de $F 1$ entre to e $t 1$, isto é, $\Delta F 1=F 1$ (tl ) - Fl (to). Aplicando essa expressão, para cada MRH, por exemplo, para o periodo 1950/80, resultaria em: $\Delta \mathrm{Fl}=\mathrm{Fl}(80)-\mathrm{Fl}(50)$. A título de ilustração, a variação do Fator 1 para a microrregião Recife, nesse periodo, foi a seguinte: $\Delta F 1=F 1(-0,072)-(0,531)=-0,603$.
} 
dos valores. Ou seja, os escores tornam-se positivos e elevados, posicionando-se, portanto, acima da média.

No Agreste, tem-se como exceção a microrregião Agreste Setentrional: considere-se que foi a única, ao lado das microrregiões canavieiras, a apresentar escore fatorial negativo $(-0,583)$, em 1980, indicando um distanciamento relativo desse tipo de força. Entretanto, em termos de tendência, apresentou evolução favorável $(0,565)$, considerando-se a variação positiva do escore fatorial no período $1950 / 80$, embora em ritmo menor, comparativamente às demais microrregiões do Agreste e Sertão.

Tabela 7.7. Variação $(\Delta)$ dos valores do Fator 1 (tração animal), segundo microrregiões homogêneas, na análise fatorial em 25 indicadores. Pernambuco, 1950 a 1980.

\begin{tabular}{lcccc}
\hline \hline Microrregião Homogênea & $\mathbf{1 9 5 0 / 6 0}$ & $\mathbf{1 9 6 0 / 7 0}$ & $\mathbf{1 9 7 0 / 8 0}$ & $\mathbf{1 9 5 0 / 8 0}$ \\
\hline Recife & $-0,454$ & $-0,026$ & $-0,123$ & $-0,603$ \\
Mata Seca & $-0,283$ & $\mathbf{0 , 0 5 1}$ & $\mathbf{0 , 0 0 2}$ & $-0,230$ \\
Mata Úmida & $-0,147$ & $\mathbf{0 , 3 3 9}$ & $-0,167$ & $\mathbf{0 , 0 2 5}$ \\
\hline Arcoverde & $\mathbf{0 , 0 5 1}$ & $\mathbf{1 , 6 5 0}$ & $\mathbf{1 , 2 8 4}$ & $\mathbf{3 , 5 2 5}$ \\
Agreste Setentrional & $-0,088$ & $\mathbf{0 , 1 8 6}$ & $\mathbf{0 , 4 6 7}$ & $\mathbf{0 , 5 6 5}$ \\
Agreste Meridional & $-0,152$ & $\mathbf{0 , 3 4 1}$ & $\mathbf{1 , 2 8 6}$ & $\mathbf{2 , 4 1 3}$ \\
Vale do Ipojuca & $-0,169$ & $\mathbf{0 , 5 5 1}$ & $\mathbf{1 , 0 8 6}$ & $\mathbf{1 , 4 6 8}$ \\
\hline Araripina & $-0,239$ & $\mathbf{0 , 2 6 1}$ & $\mathbf{1 , 3 5 4}$ & $\mathbf{1 , 3 7 6}$ \\
Salgueiro & $-0,285$ & $\mathbf{0 , 1 4 4}$ & $\mathbf{1 , 7 1 2}$ & $\mathbf{1 , 5 7 1}$ \\
Sertão do São Francisco & $-0,465$ & $\mathbf{0 , 9 4 8}$ & $\mathbf{1 , 5 6 4}$ & $\mathbf{2 , 0 4 7}$ \\
Sertão do Moxotó & $-0,279$ & $\mathbf{0 , 6 4 4}$ & $\mathbf{2 , 7 3 0}$ & $\mathbf{3 , 0 9 5}$ \\
Alto Pajeú & $-0,180$ & $\mathbf{0 , 9 5 7}$ & $\mathbf{2 , 2 8 0}$ & $\mathbf{3 , 0 5 7}$ \\
\hline \hline
\end{tabular}

Fonte: Dados do IBGE, Censos Agrícolas de 1950 e 1960 e Censos Agropecuários de 1970 e 1980 (PE), processados através do SAS. 
As maiores variações positivas do Fator 1, no periodo 1950/80 pertencem às microrregiões Arcoverde $(3,525)$, Sertão do Moxotó $(3,095)$ e Alto Pajeú $(3,057)$. Excetuando-se as microrregiões da zona canavieira e o Agreste Setentrional, mesmo a menor variação pode ser considerada alta: 1,376 (Araripina). Ou seja, uma das dimensões da tecnificação do processo produtivo das microrregiões do Agreste e Sertão consistiu na difusão e incorporação da tração animal. Esse processo fôra iniciado no subperiodo 1960/70 e mantido no subperíodo seguinte: 1970/80.

O segundo fator (F2) representa a pecuária melhorada, principalmente em áreas onde as lavouras têm relativa expressividade. Em 1950, os mais elevados escores pertencem às microrregiões Recife e Mata Seca. Na mesorregião Agreste, o Agreste Meridional, e no Sertão, a microrregião Alto do Pajeú. Opostamente, valores negativos são exibidos principalmente pela microrregião Sertão do São Francisco, além de Salgueiro e Sertão do Moxotó, indicando áreas de predominância de pecuária mais extensiva.

Tabela 7.8. Valores do Fator 2 (pecuária melhorada), segundo microrregiões homogêneas, na análise fatorial em 25 indicadores. Pernambuco, 1950 a 1980.

\begin{tabular}{lcccc}
\hline Microrregião Homogênea & $\mathbf{1 9 5 0}$ & $\mathbf{1 9 6 0}$ & $\mathbf{1 9 7 0}$ & $\mathbf{1 9 8 0}$ \\
\hline Recife & $\mathbf{1 , 7 8 4}$ & $\mathbf{0 , 3 2 2}$ & $\mathbf{1 , 7 4 7}$ & $\mathbf{1 , 7 0 9}$ \\
Mata Seca & $\mathbf{1 , 4 7 6}$ & $\mathbf{1 , 0 3 2}$ & $\mathbf{1 , 0 2 3}$ & $\mathbf{1 , 0 4 8}$ \\
Mata Úmida & $\mathbf{0 , 4 8 7}$ & $\mathbf{0 , 4 6 4}$ & $\mathbf{0 , 4 0 9}$ & $\mathbf{0 , 8 8 9}$ \\
\hline Arcoverde & $\mathbf{0 , 4 4 9}$ & $-0,742$ & $-0,249$ & $\mathbf{0 , 3 9 9}$ \\
Agreste Setentrional & $\mathbf{0 , 5 0 9}$ & $\mathbf{0 , 7 7 9}$ & $\mathbf{0 , 4 4 1}$ & $\mathbf{0 , 1 5 9}$ \\
Agreste Meridional & $\mathbf{0 , 9 7 5}$ & $\mathbf{0 , 5 2 7}$ & $\mathbf{0 , 3 9 0}$ & $\mathbf{0 , 5 0 0}$ \\
Vale do Ipojuca & $\mathbf{0 , 4 3 4}$ & $-0,150$ & $-0,087$ & $\mathbf{0 , 0 5 5}$ \\
\hline Araripina & $\mathbf{0 , 0 3 2}$ & $-0,631$ & $-0,975$ & $-0,801$ \\
Salgueiro & $-0,298$ & $-0,878$ & $-1,632$ & $-0,964$ \\
Sertão do São Francisco & $-1,365$ & $-2,526$ & $-1,947$ & $-2,280$ \\
Sertão do Moxotó & $-0,071$ & $-0,915$ & $-1,087$ & $-0,619$ \\
Alto Pajeú & $\mathbf{0 , 7 2 8}$ & $-0,609$ & $-0,118$ & $\mathbf{0 , 1 7 4}$ \\
\hline \hline
\end{tabular}

Fonte: Dados do IBGE, Censos Agricolas de 1950 e 1960 e Censos Agropecuários de 1970 e 1980 (PE), processados através do SAS. 
Em termos de variação dos valores do Fator 2 para cada subperiodo, de acordo com a leitura dos dados da tabela 7.9, venifica-se que entre: 1950/60, à excefão do Agreste Setentrional, todas as demais microrregiões apresentaram variação negativa; 1960/70, somente Recife, Arcoverde e Vale do Ipojuca exibiram variação positiva; 1970/80, quase todas as microrregiões apresentam variação positiva, exceto Recife, cujo valor praticamente se mantém estável, e o Agreste Setentrional e o Sertão do São Francisco. Para o período completo, 1950/80, à exceção da Mata Úmida, todas as demais microrregiões apresentaram variação negativa. As microrregiões Recife e Arcoverde revelaram relativa estabilidade. De um modo geral, as variações negativas foram mais acentuadas nas microrregiões do Sertão do que nas do Agreste.

Tabela 7.9. Variação $(\Delta)$ dos valores do Fator 2 (pecuária melhorada), segundo microrregiões homogêneas, na análise fatorial em 25 indicadores. Pernambuco, 1950 a 1980.

\begin{tabular}{lcccc}
\hline Microrregião Homogênea & $\mathbf{1 9 5 0 / 6 0}$ & $\mathbf{1 9 6 0 / 7 0}$ & $\mathbf{1 9 7 0 / 8 0}$ & $\mathbf{1 9 5 0 / 8 0}$ \\
\hline Recife & $-1,462$ & $\mathbf{1 , 4 2 5}$ & $-0,038$ & $-0,075$ \\
Mata Seca & $-0,444$ & $-0,009$ & $\mathbf{0 , 0 2 5}$ & $-0,428$ \\
Mata Úmida & $-0,023$ & $-0,055$ & $\mathbf{0 , 4 8 0}$ & $\mathbf{0 , 4 0 2}$ \\
\hline Arcoverde & $-1,191$ & $\mathbf{0 , 4 9 3}$ & $\mathbf{0 , 6 4 8}$ & $-0,050$ \\
Agreste Setentrional & $\mathbf{0 , 2 7 0}$ & $-0,338$ & $-0,282$ & $-0,350$ \\
Agreste Meridional & $-0,448$ & $-0,137$ & $\mathbf{0 , 1 1 0}$ & $-0,475$ \\
Vale do Ipojuca & $-0,584$ & $\mathbf{0 , 0 6 3}$ & $\mathbf{0 , 1 4 2}$ & $-0,379$ \\
\hline Araripina & $-0,663$ & $-0,344$ & $\mathbf{0 , 1 7 4}$ & $-0,833$ \\
Salgueiro & $-0,580$ & $-0,754$ & $\mathbf{0 , 6 6 8}$ & $-0,666$ \\
Sertão do São Francisco & $-1,161$ & 0,579 & $-0,333$ & $-0,915$ \\
Sertão do Moxotó & $-0,844$ & $-0,172$ & $\mathbf{0 , 4 6 8}$ & $-0,548$ \\
Alto Pajeú & $-1,337$ & 0,491 & $\mathbf{0 , 2 9 2}$ & $-0,554$ \\
\hline \hline
\end{tabular}

Fonte: Dados do IBGE, Censos Agricolas de 1950 e 1960 e Censos Agropecuários de 1970 e 1980 (PE), procescados através do SAS. 
Apesar das variações negativas, a principal constatação, é a de que quase todas as microrregiões que apresentavam valores positivos de F2, em 1950, continuaram com valores positivos em 1980. A exceção cabe a Araripina, cujo valor torna-se negativo a partir de 1960 . Ou seja, a pecuária melhorada continuaria a ser praticada nas mesmas microrregiões, apesar de decorridos 30 anos: as microrregiões da Zona canavieira, as microrregiões do Agreste e, no Sertão, apenas a microrregião Alto Pajeú.

Enquanto tendência de modernização da pecuária melhorada, apenas a microrregião canavieira Mata Úmida, revelou evolução favorável, no período 1950/80. Entretanto, considerando-se o subperíodo 1970/80, conforme já mencionado, observa-se a existência de variações positivas para quase todas as microrregiões, indicando melhoria do padrão tecnológico da atividade.

A principal medida de modemização é externada pelo Fator 3. Seu significado principal é a mecanização - através da utilização de tratores e arados associada ao uso de insumos modernos, com ênfase em áreas de predomínio da cana-deaçúcar. Em 1950, de acordo com os valores positivos desse fator, encontravam-se relativamente modemizadas ${ }^{22}$, as microrregiões Recife, Mata Úmida e Sertão do São Francisco; a partir de 1960, além dessas microrregiões, integra-se às microrregiões, nas quais a mecanização é relativamente mais intensiva, a microrregião Mata Seca. Em 1980, soma-se as microrregiões Salgueiro e Agreste Setentrional.

\footnotetext{
22 Não quer dizer que todas as áreas ou atividades dessas microrregiões estejam modemizadas. Como foi visto, a modernização é bastante parcial e heterogênea. Então, nessas microrregiões, convivem e se integram atividades modernizadas ou em modemização, e atividades bastante distantes do processo. O exemplo mais ilustrativo é o do Sertão do São Francisco, micronegião na qual convivem uma modena agricultura irrigada, e uma agricultura tradicional, de subsistência, em áreas de sequeiro, juntamente a uma pecuária fortemente extensiva. $O$ valor poisitivo do Fator está apenas indicando que a mecanização está acima da média.
} 
Tabela 7.10. Valores do Fator 3 (mecanização com ênfase na cana-de-açúcar), segundo microrregiões homogêneas, na análise fatorial em 25 indicadores. Pernambuco, 1950 a 1980.

\begin{tabular}{lcccc}
\hline Microrregião Homogênea & $\mathbf{1 9 5 0}$ & $\mathbf{1 9 6 0}$ & $\mathbf{1 9 7 0}$ & $\mathbf{1 9 8 0}$ \\
\hline Recife & $\mathbf{0 , 1 0 6}$ & $\mathbf{2 , 7 1 6}$ & $\mathbf{0 , 5 6 3}$ & $\mathbf{1 , 7 3 8}$ \\
Mata Seca & $-0,612$ & $\mathbf{0 , 4 3 3}$ & $\mathbf{1 , 1 6 9}$ & $\mathbf{3 , 1 5 4}$ \\
Mata Úmida & $\mathbf{0 , 3 2 8}$ & $\mathbf{0 , 5 9 0}$ & $\mathbf{0 , 7 7 3}$ & $\mathbf{1 , 8 7 3}$ \\
\hline Arcoverde & $-1,101$ & $-0,346$ & $-0,887$ & $-0,969$ \\
Agreste Setentrional & $-1,060$ & $-0,891$ & $-0,609$ & $\mathbf{0 , 3 2 9}$ \\
Agreste Meridional & $-1,164$ & $-0,502$ & $-0,795$ & $-0,293$ \\
Vale do Ipojuca & $-0,740$ & $-0,287$ & $-0,482$ & $-0,123$ \\
\hline Araripina & $-1,025$ & 0,164 & $-0,608$ & $-0,030$ \\
Salgueiro & $-0,899$ & $-0,245$ & $-0,160$ & $\mathbf{0 , 5 5 2}$ \\
Sertão do São Francisco & $\mathbf{0 , 0 4 4}$ & $\mathbf{1 , 1 9 1}$ & $\mathbf{0 , 3 4 4}$ & $\mathbf{2 , 0 3 7}$ \\
Sertão do Moxotó & $-0,832$ & $-0,125$ & $-0,274$ & $-0,372$ \\
Alto Pajeú & $-1,012$ & $-0,003$ & $-0,761$ & $-0,566$ \\
\hline \hline
\end{tabular}

Fonte: Dados do IBGE, Censos Agrícolas de 1950 e 1960 e Censos Agropecuários de 1970 e 1980 (PE), processados através do SAS.

Segundo os valores apresentados na tabela 7.11, considerando-se os subperiodos, observa-se que entre 1950/60, houve uma aceleração do processo de modernização: todas as variações são positivas e, grosso modo, elevadas; no periodo seguinte, 1960/70, há um enfraquecimento do processo (à exceção da Mata Seca, Mata Úmida, Agreste Setentrional e Salgueiro); no período 1970/80, o processo é fortalecido, em quase todas as microrregiões, à exceção de Arcoverde e Sertão do Moxotó, que exibem variação negativa: as maiores variações positivas pertencem às microrregiões canavieiras, principalmente a Mata Seca (1,985), e na mesorregião Sertão, à microrregião Sertão do São Francisco $(1,693)$. Mas, considerando-se, também, os valores entre $+0,6$ e $+1,0$, têm-se as microrregiões Agreste Setentrional e Salgueiro. 
Tabela 7.11. Variação $(\Delta)$ dos valores do Fator 3 (mecanização com ênfase na cana-deaçúcar), segundo microrregiões homogêneas, na análise fatorial em 25 indicadores. Pernambuco, 1950 a 1980.

\begin{tabular}{lcccc}
\hline Microrregião Homogênea & $\mathbf{1 9 5 0 / 6 0}$ & $\mathbf{1 9 6 0 / 7 0}$ & $\mathbf{1 9 7 0 / 8 0}$ & $\mathbf{1 9 5 0 / 8 0}$ \\
\hline Recife & $\mathbf{2 , 6 1 0}$ & $-2,153$ & $\mathbf{1 , 1 7 5}$ & $\mathbf{1 , 6 3 2}$ \\
Mata Seca & $\mathbf{1 , 0 4 5}$ & $\mathbf{0 , 7 3 6}$ & $\mathbf{1 , 9 8 5}$ & $\mathbf{3 , 7 6 6}$ \\
Mata Úmida & $\mathbf{0 , 2 6 2}$ & $\mathbf{0 , 1 8 3}$ & $\mathbf{1 , 1 6 0}$ & $\mathbf{1 , 5 4 5}$ \\
\hline Arcoverde & $\mathbf{0 , 7 5 5}$ & $-0,541$ & $-0,082$ & $\mathbf{0 , 1 3 2}$ \\
Agreste Setentrional & $\mathbf{0 , 1 6 9}$ & $\mathbf{0 , 2 8 2}$ & $\mathbf{0 , 9 3 8}$ & $\mathbf{1 , 3 8 9}$ \\
Agreste Meridional & $\mathbf{0 , 6 6 2}$ & $-0,293$ & $\mathbf{0 , 5 0 2}$ & $\mathbf{0 , 8 7 1}$ \\
Vale do Ipojuca & $\mathbf{0 , 4 5 3}$ & $-0,195$ & $\mathbf{0 , 3 5 9}$ & $\mathbf{0 , 6 1 7}$ \\
\hline Araripina & $\mathbf{1 , 1 8 9}$ & $-0,772$ & $\mathbf{0 , 5 7 8}$ & $\mathbf{0 , 9 9 5}$ \\
Salgueiro & $\mathbf{0 , 6 5 4}$ & $\mathbf{0 , 0 8 5}$ & $\mathbf{0 , 7 1 2}$ & $\mathbf{1 , 4 5 1}$ \\
Sertão do São Francisco & $\mathbf{1 , 1 4 7}$ & $-0,847$ & $\mathbf{1 , 6 9 3}$ & $\mathbf{1 , 9 9 3}$ \\
Sertão do Moxotó & $\mathbf{0 , 7 0 7}$ & $-0,149$ & $-0,098$ & $\mathbf{0 , 4 6 0}$ \\
Alto Pajeú & $\mathbf{1 , 0 0 9}$ & $-0,758$ & $\mathbf{0 , 1 9 5}$ & $\mathbf{0 , 4 4 6}$ \\
\hline \hline
\end{tabular}

Fonte: Dados do IBGE, Censos Agricolas de 1950 e 1960 e Censos Agropecuánios de 1970 e 1980 (PE), processados através do SAS.

Em termos de evolução ou tendência, considerando-se o período de 30 anos (1950/80), para todas as microrregiões houve variação positiva do escore fatorial (tabela 7.11). Na zona canavieira, e, no Estado, de modo geral, a microrregião que apresentou a variação positiva mais intensa foi a Mata Seca $(3,766)$. A segunda maior variação positiva pertence ao Sertão do São Francisco $(1,993)$. Na mesorregião Agreste, a maior variação foi apresentada pelo Agreste Setentrional $(1,389)$. As microrregiões cujo processo revelou-se mais lento, são três: Arcoverde $(0,132)$, Sertão do Moxotó $(0,460)$ e Alto Pajeú $(0,446)$.

Como evidenciado, apesar de um quadro de evolução tendencial favorável para todas as microrregiões, em 1980 apenas a metade das 12 microrregiões apresentou escores positivos, portanto, acima da média: com escore superior a $+3,00$, somente a Mata Seca; superior a + 1,00, as MRHs Recife e Mata Úmida; também positivos, mas inferiores a $+1,00$, as MRHs Salgueiro e Agreste Setentrional (tabela 7.10). 
Na exposição gráfica a seguir, apresenta-se a evolução dos escores do Fator 3 (mecanização), entre 1950 e 1980, por grupos de microrregiões, segundo as mesorregiões que as contêm. E, na sequeência, a evolução conjunta do Fator 3 e do Fator 1 (tração animal).

Na Figura 7.1 está revelada a tendência de F3 para as três microrregiões homogêneas da Zona da Mata. Entre 1960 e 1970, observa-se uma queda abrupta do valor de F3 para a MRH Recife. Afora essa discrepância, a inspeção gráfica aponta para uma evolução positiva do fator nas três microrregiões, sendo que a Mata Seca revela um incremento tendencial mais consistente, secundada pela Mata Úmida.

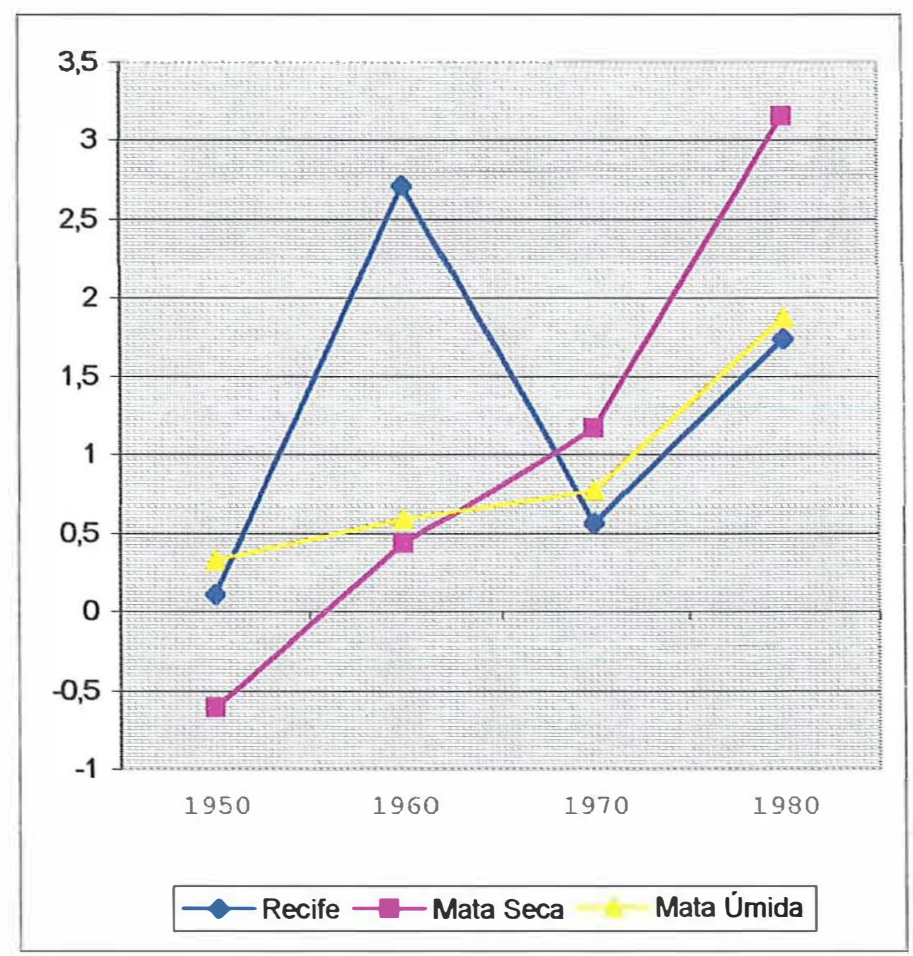

Figura 7.1 Tendências do Fator 3 (mecanização) nas microrregiões canavieiras entre 1950 e 1980 
Na Figura 7.2 visualiza-se a tendência de F3 para as quatro microrregiões da mesorregião Agreste. Salta à vista a evolução tendencial favorável e consistente da modernização no Agreste Setentrional, década a década, de 1950 a 1980.

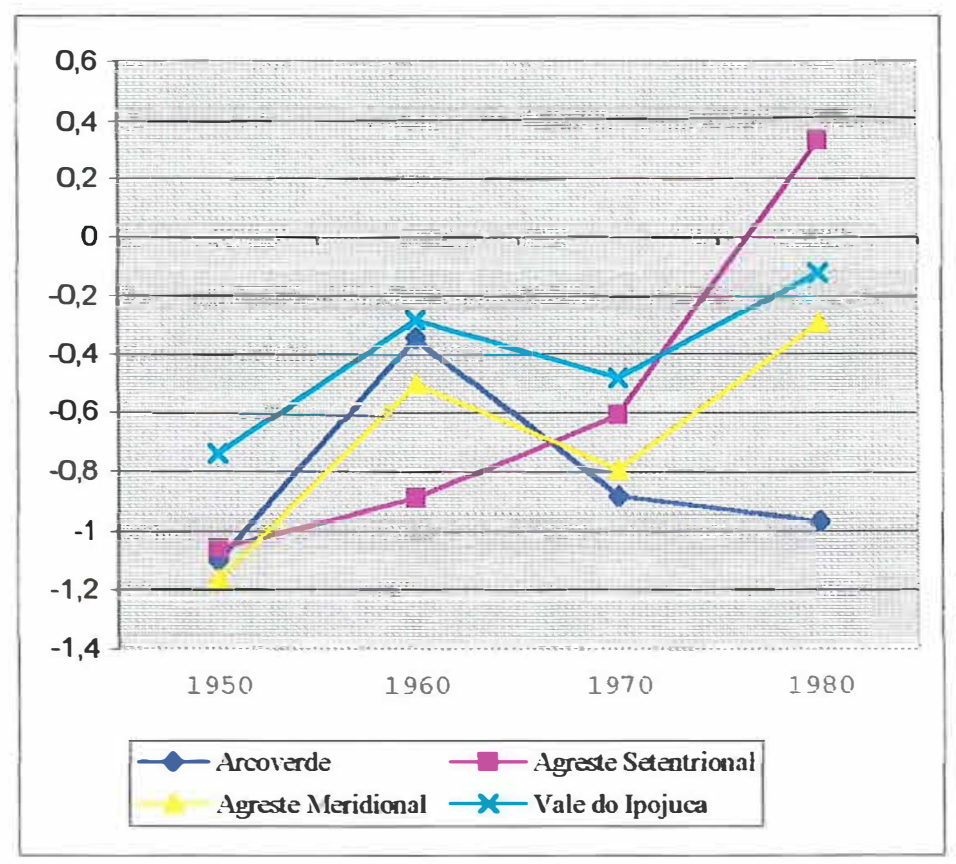

Figura 7.2 Tendências do Fator 3 (mecanização)

na mesorregião Agreste entre 1950 e 1980 
A evolução dos escores das microrregiões da mesorregião Sertão encontra-se apresentada na Figura 7.3. A microrregião mais modernizada e com evolução mais consistente do Fator 3 é revelada pelo Sertão Pernambucano do São Francisco.

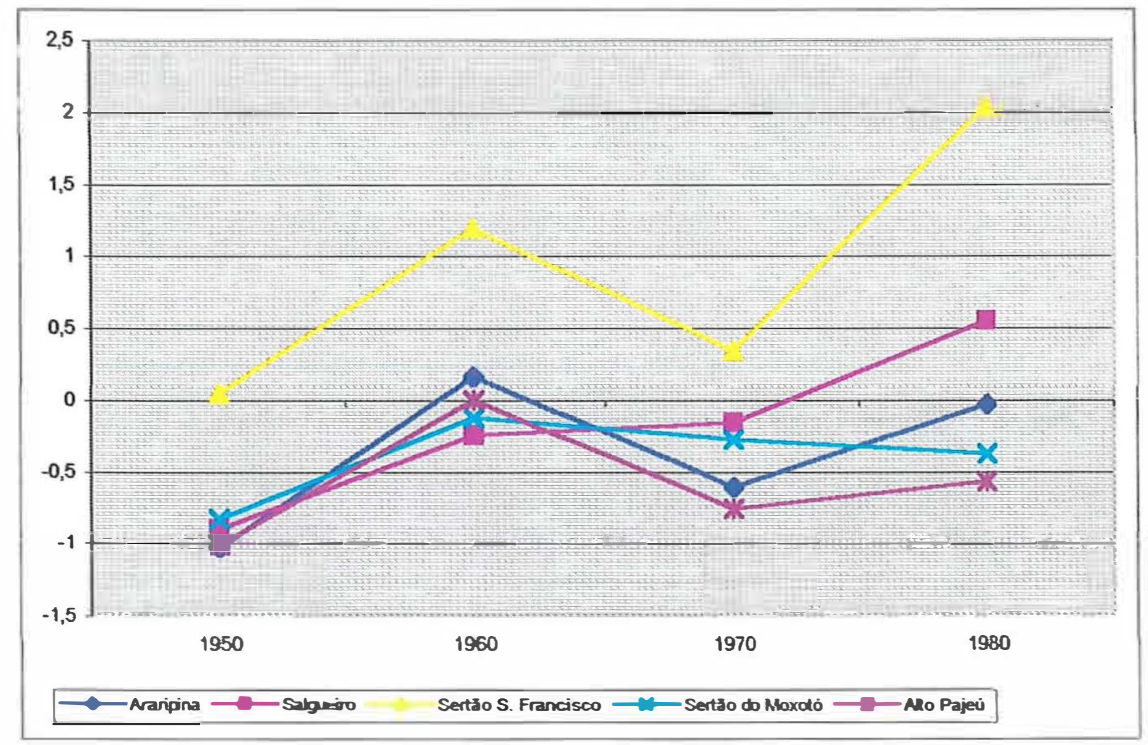

Figura 7.3 Tendências do Fator 3 (mecanização) na mesorregião Sertão entre 1950 e 1980

Observe-se que o Fator 1 (tração animal) e o Fator 3 (mecanização) se completam. Ambos representam dois tipos bastantes distintos de tecnificação do processo produtivo. A titulo de exemplo, mencione-se Arcoverde: para 1980, essa microrregião, dentre as demais, foi a que apresentou o maior valor do Fator $1(3,108)$ e a maior variação positiva no período 1950/80 (3,525); entretanto, é a que detém o menor valor do Fator $3(-0,969)$, em 1980, bem como a menor variação no período $1950 / 80(0,132)$. Situação idêntica pode ser descrita para as microrregiões Sertão do Moxotó e Alto Pajeú. Ou seja, microrregiões em que a tração animal tem maior expressão e que tiveram evolução positiva e acentuada no período, apresentaram posição e comportamento inverso com relação à tração mecânica. Quer dizer, há uma oposição, ou uma relação freqüentemente inversa entre F1 e F3. 
Na Figura 7.4 pode-se observar a relação inversa entre F1 e F3, para as microrregiões Arcoverde, Sertão do Moxotó e Vale do Pajeú. Além da evolução bastante favorável da tração animal, no período 1950/80, essas unidades se caracterizam, também, por terem apresentado uma tendência praticamente estagnada de F3, ou seja da modernização convencional, ou, principalmente, da mecanização intensiva.
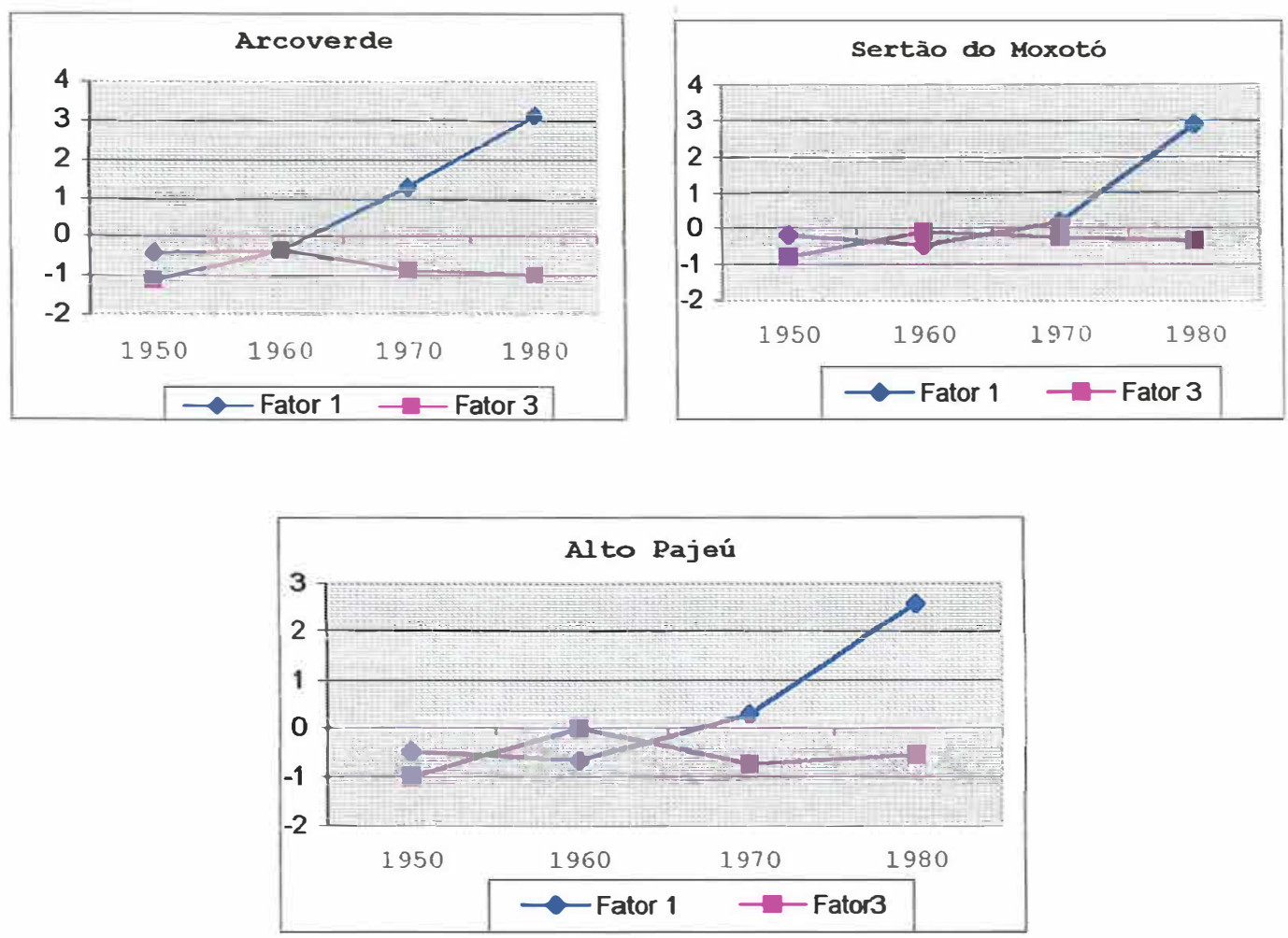

Figura 7.4 Tendências do Fator 1 (tração animal) e do Fator 3 (mecanização) nas microrregiões Arcoverde, Sertão do Moxotó e Alto Pajeú entre 1950 e 1980 
Um outro conjunto de três microrregiões - Agreste Meridional, Vale do Ipojuca e Araripina - apresentou, também, relação inversa entre F1 e F3. A diferença cabe ao comportamento de F3: embora com valores baixos e negativos, é possível verificar, através da Figura 7.5, uma leve tendência de crescimento dos escores fatoriais para as microrregiões assinaladas, isto é, da modernização. Contudo, prevalece o crescimento vigoroso e consistente da tração animal, representada pela variável sintética F1.
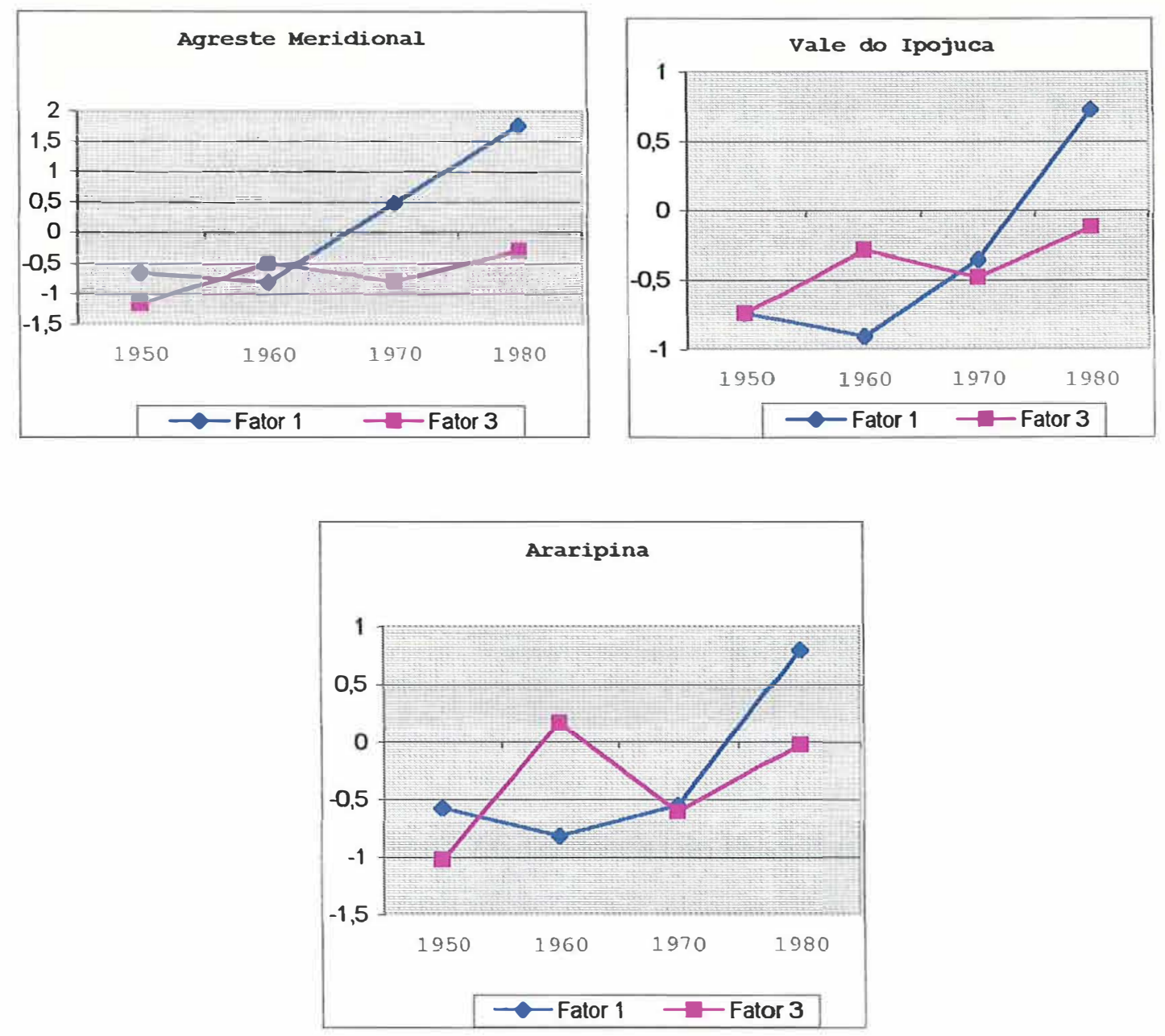

Figura 7.5 Tendências do Fator 1 (tração animal) e do Fator 3 (mecanização) nas microrregiões Agreste Meridional, Vale do Ipojuca e Araripina entre 1950 e 1980 
Duas outras microrregiões, Sertão do São Francisco e Salgueiro, exibem uma associação claramente positiva entre F1 e F3, com a seguinte diferença: naquela, o valor de F3 é mais elevado, enquanto nesta, é o valor de F1 (Figura 7.6). Em resumo, ambas microrregiões apresentam evolução favorável tanto da tração animal quanto de uma modemização mais convencional, alavancada pela tração mecânica. Em se tratando da microrregião São Franciscana, esse comportamento tendencial, aparentenente dúbio, é explicado pela convivência de dois tipos de agricultura: a moderna e irrigada, e a tradicional e de sequeiro. Ou seja, ocorre uma dualidade tecnológica acentuada, em face da existência simultânea de atividades agrícolas tradicionais e modemizadas, sendo que o peso relativo do setor tradicional é bastante expressivo, principalmente na MRH Salgueiro.
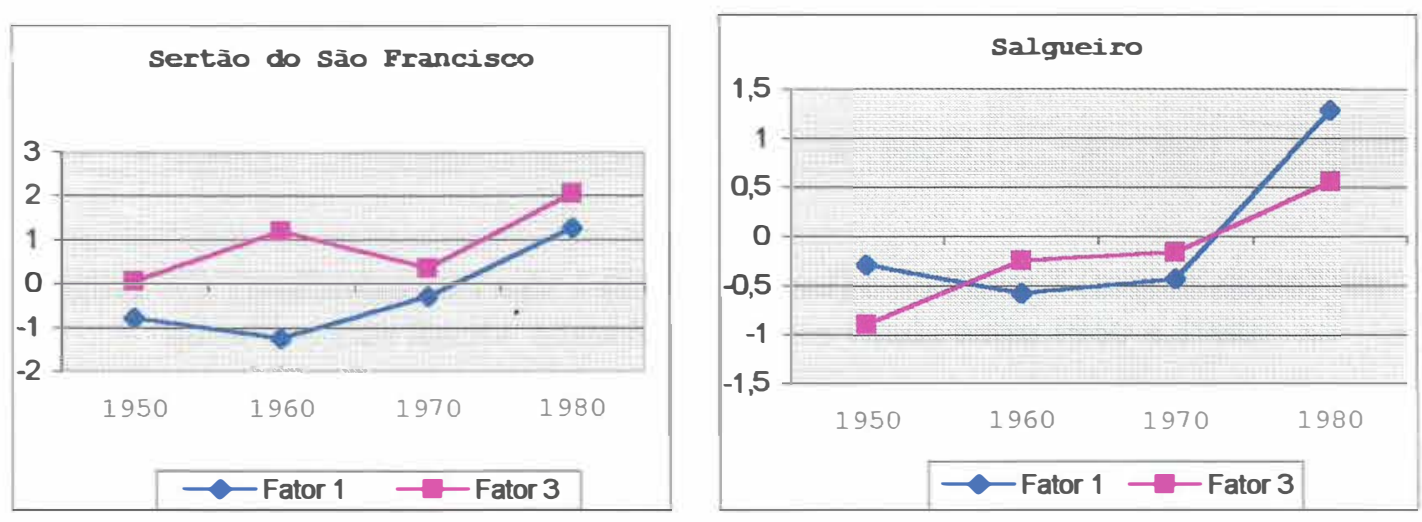

Figura 7.6 Tendências do Fator 1 (tração animal) e do Fator 3

(mecanização) nas microrregiões Sertão do São Francisco

e Salgueiro entre 1950 e 1980 
Somente as microrregiões Recife, Mata Seca, Mata Úmida e Agreste Setentrional exibiram valor negativo de F1, em 1980 (Figura 7.7). Particularmente com referência às microrregiões da zona canavieira, a singularidade é bastante visível: ascenção dos valores de F3, no período 1950/80, e comportamento estagnado, com tendência declinante de F1.
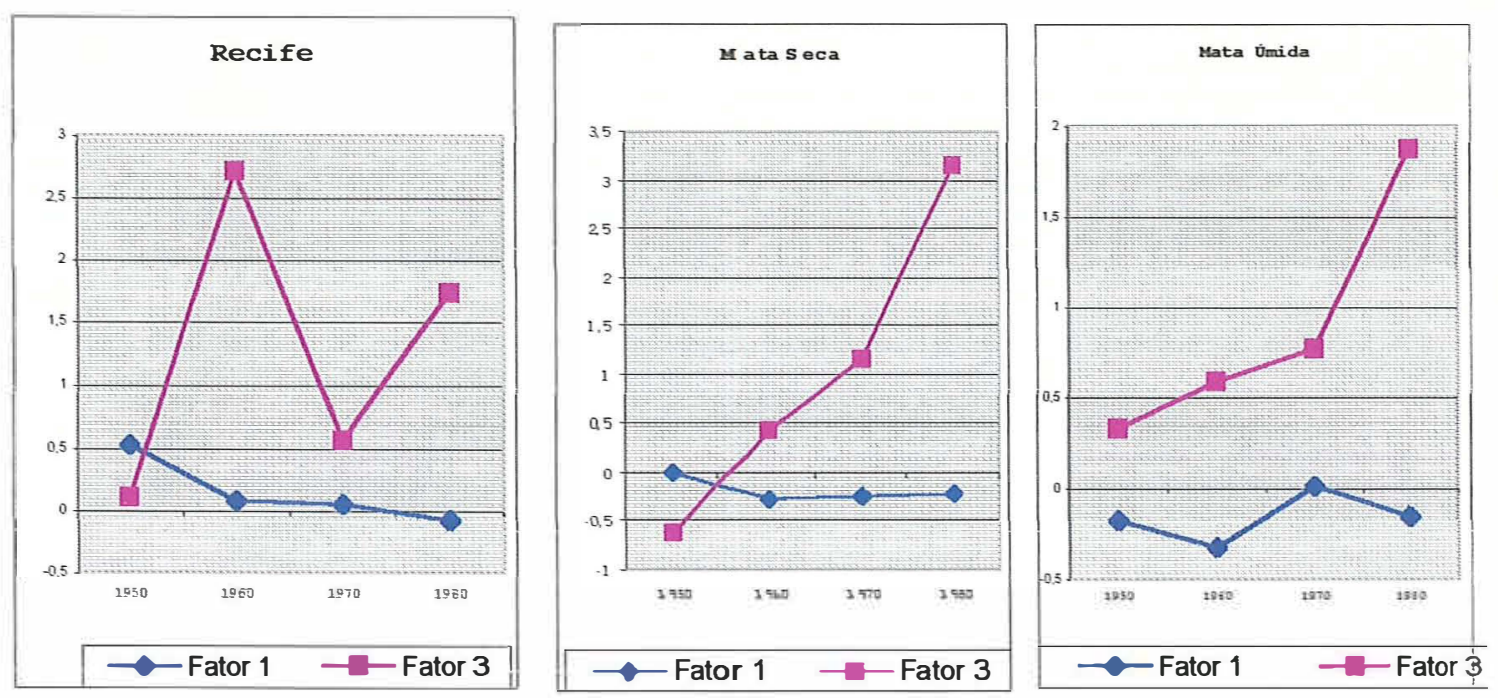

Figura 7.7 Tendências do Fator 1 (tração animal) e do Fator 3 (mecanização) nas microrregiões Recife, Mata Seca e Mata Únida entre 1950 e 1980 
Para o Agreste Setentrional, apesar de ambos fatores revelarem crescimento, F1 (tração animal) continua negativo, enquanto F3 (modernização) torna-se positivo, isto é, essa microrregião passa a se posicionar acima da média, em 1980.

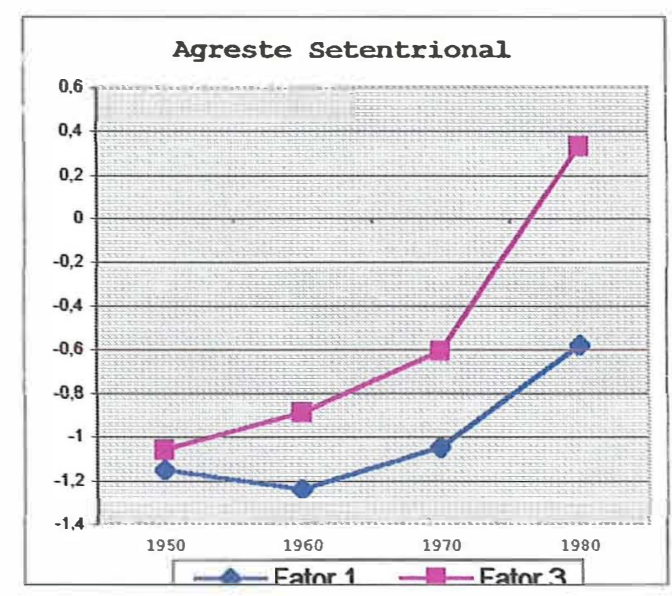

Figura 7.8 Tendências do Fator 1 (tração animal) e do

Fator 3 (mecanização) na microrregião Agreste

Setentrional entre 1950 e 1980

O Fator 4 representa a dimensão onde estão encadeados o assalariamento $(\mathrm{X} 22=0,717 ; \mathrm{X} 11=0,693)$ e as relações de trabalho não-modernizadas $(\mathrm{X} 25=0,702)$, em sistemas de produção nos quais se manifesta relativa ociosidade das terras disponíveis $(\mathrm{X} 20=0,840)$. Apresentou associação positiva e moderada com relação à participação do valor das máquinas e instrumentos agrários no valor total dos bens (X10 $=0,530$ ). Entretanto, associou-se negativamente com todos os demais indicadores de mecanização (X1, X4, X5, X6 e X8), inclusive o uso de tração animal (X2). Em consequência, apresentou associação positiva com os estabelecimentos sem declaração de uso de força animal ou mecânica, ou de uso exclusivo de força humana (X3). Quer dizer, o Fator 4 está refletindo o conjunto de estabelecimentos nos quais predomina o uso de força humana, e as demais forças - mecânica e animal - encontram-se escassamente disseminadas e, quando empregadas, não há intensidade. Corroborando tratar-se de um 
padrão de modemização elementar ou incipiente, observe-se a associação negativa de F4 com o indicador de despesas relacionadas aos insumos químico-biológicos (X12). Ou seja, valores positivos do fator estarão indicando predominantemente aspectos de atraso e valores negativos, os de desenvolvimento.

Década a década, a partir de 1950, segundo se depreende do exame da tabela 7.12, grosso modo, os valores positivos de F4 apresentam comportamento decrescente: dependendo da microrregião, considerando-se o ano de 1980 como final do processo, alguns valores continuam positivos, porém inferiores aos de 1950, e outros passaram a valores negativos. Ou seja, está-se partindo de uma situação de atraso para um quadro de desenvolvimento.

Em 1980, as únicas microrregiões que, ainda, apresentam valores positivos são Salgueiro, Sertão do Moxotó e Alto Pajeú. Recorde-se que a utilização da tração animal e, em decorrência, dos sistemas agrícolas tradicionais em que se insere, é predominante nessas unidades e onde a mecanização evoluiu com menor intensidade, segundo a análise anterior.

Tabela 7.12. Valores do Fator 4 ("assalariamento e relações de trabalho nãomodemizadas e subutilização do recurso terra"), segundo microrregiões homogêneas, na análise fatorial em 25 indicadores. Pernambuco, 1950 a 1980.

\begin{tabular}{lcccc}
\hline Microrregião Homogênea & $\mathbf{1 9 5 0}$ & $\mathbf{1 9 6 0}$ & $\mathbf{1 9 7 0}$ & $\mathbf{1 9 8 0}$ \\
\hline Recife & $\mathbf{1 , 2 7 9}$ & $\mathbf{1 , 3 0 8}$ & $\mathbf{0 , 0 7 3}$ & $-0,820$ \\
Mata Seca & $\mathbf{1 , 3 3 4}$ & $\mathbf{0 , 8 8 7}$ & $-0,354$ & $-0,885$ \\
Mata Úmida & $\mathbf{1 , 8 4 5}$ & $\mathbf{1 , 2 8 4}$ & $\mathbf{0 , 5 0 2}$ & $-0,209$ \\
\hline Arcoverde & $\mathbf{0 , 2 0 1}$ & $-0,233$ & $-0,427$ & $-0,402$ \\
Agreste Setentrional & $-0,983$ & $-1,875$ & $-1,796$ & $-1,774$ \\
Agreste Meridional & $\mathbf{0 , 5 0 9}$ & $-0,721$ & $-1,254$ & $-1,422$ \\
Vale do Ipojuca & $-0,065$ & $-0,931$ & $-1,396$ & $-1,342$ \\
\hline Araripina & $\mathbf{1 , 8 6 3}$ & $\mathbf{0 , 7 2 1}$ & $-0,396$ & $-0,346$ \\
Salgueiro & $\mathbf{2 , 0 1 9}$ & $\mathbf{1 , 5 0 2}$ & $\mathbf{0 , 1 5 4}$ & $\mathbf{0 , 3 5 6}$ \\
Sertão do São Francisco & $\mathbf{0 , 4 8 3}$ & $-0,111$ & $-0,547$ & $-0,274$ \\
Sertão do Moxotó & $\mathbf{1 , 1 9 0}$ & $\mathbf{0 , 2 8 2}$ & $-0,334$ & $\mathbf{0 , 5 0 4}$ \\
Alto Pajeú & $\mathbf{0 , 6 4 5}$ & $\mathbf{0 , 1 8 0}$ & $-0,393$ & $\mathbf{0 , 1 6 9}$ \\
\hline \hline
\end{tabular}

Fonte: Dados do IBGE, Censos Agricolas de 1950 e 1960 e Censos Agropecuánios de 1970 e 1980 (PE), processados através do SAS. 
Considerando-se os dados da tabela 7.13, observa-se que, juntamente com Arcoverde $(-0,603)$, as microrregiões Alto Pajeú $(-0,476)$ e Sertão do Moxotó $(-0,686)$, apresentaram as menores variações negativas do fator no período 1950/80. Em outras palavras, o afastamento em relação a aspectos de atraso foi menos intenso. $\mathrm{O}$ mesmo não se pode dizer das microrregiões da Zona da Mata, em face das altas variações negativas apresentadas no período: Mata Seca $(-2,219)$, Mata Úmida $(-2,054)$ e Recife $(-2,099)$

Também cabe mencionar a MRH Salgueiro que, apesar de haver apresentado, em 1980, valor positivo de F4, revelou tendência de distanciamento em relação a essa dimensão, em face da elevada variação negativa do fator observada no período 1950/80 (-1,663). Recorde-se que essa microrregião, tanto em termos de tração animal (F1) quanto de mecanização (F3) e, também da pecuária melhorada, considerando-se o subperíodo 1970/80, apresentou evolução bastante favorável. Em termos do ranking de valores de F4, a microrregião sertaneja de Salgueiro, afora as microrregiões da zona canavieira (valores de -2,054 a -2,219), foi a segunda a apresentar a maior variação negativa $(-1,633)$, após Araripina $(-2,209)$. 
Tabela 7.13. Variação $(\Delta)$ dos valores do Fator 4 ("assalariamento e relações de trabalho não-modernizadas e subutilização do recurso terra"), segundo microrregiões homogêneas, na análise fatorial em 25 indicadores. Pernambuco, 1950 a 1980 .

\begin{tabular}{lcccc}
\hline Microrregião Homogênea & $\mathbf{1 9 5 0 / 6 0}$ & $\mathbf{1 9 6 0 / 7 0}$ & $\mathbf{1 9 7 0 / 8 0}$ & $\mathbf{1 9 5 0 / 8 0}$ \\
\cline { 2 - 6 } Recife & $\mathbf{0 , 0 2 9}$ & $-1,235$ & $-0,893$ & $-2,099$ \\
Mata Seca & $-0,447$ & $-1,241$ & $-0,531$ & $-2,219$ \\
Mata Úmida & $-0,561$ & $-0,782$ & $-0,711$ & $-2,054$ \\
\hline Arcoverde & $-0,434$ & $-0,194$ & $\mathbf{0 , 0 2 5}$ & $-0,603$ \\
Agreste Setentrional & $-0,892$ & $\mathbf{0 , 0 7 9}$ & $\mathbf{0 , 0 2 2}$ & $-0,791$ \\
Agreste Meridional & $-1,230$ & $-0,533$ & $-0,168$ & $-0,913$ \\
Vale do Ipojuca & $-0,866$ & $-0,465$ & $\mathbf{0 , 0 5 4}$ & $-1,277$ \\
\hline Araripina & $-1,142$ & $-1,117$ & $\mathbf{0 , 0 5 0}$ & $-2,209$ \\
Salgueiro & $-0,517$ & $-1,348$ & $\mathbf{0 , 2 0 2}$ & $-1,663$ \\
Sertão do São Francisco & $-0,594$ & $-0,436$ & $\mathbf{0 , 2 7 3}$ & $-0,757$ \\
Sertão do Moxotó & $-0,908$ & $-0,616$ & $\mathbf{0 , 8 3 8}$ & $-0,686$ \\
Alto Pajeú & $-0,465$ & $-0,573$ & $\mathbf{0 , 5 6 2}$ & $-0,476$ \\
\hline \hline
\end{tabular}

Fonte: Dados do IBGE, Censos Agricolas de 1950 e 1960 e Censos Agropecuários de 1970 e 1980 (PE), processados através do SAS.

Em termos de mesorregião, esse processo foi mais consistente na Zona da Mata, dado que as variações do Fator 4, referentes às três microrregiões que a compõem, foram altos e de valores muito próximos: Recife $(-2,099)$, Mata Seca $(-2,219)$ e Mata Úmida (-2,054). No Agreste, a variação menos expressiva foi de Arcoverde, e no Sertão, a do Alto Pajeú.

Esses valores continuam a corroborar os resultados de análises anteriores no sentido de apontar Arcoverde, Alto do Pajeú e Sertão do Moxotó, como as microrregiões em que o nível de modemização tem-se mostrado mais incipiente, sob o prisma de uma tecnificação clássica: tratores + insumos químico-biológicos.

Entretanto, não se pode desconhecer que a crescente utilização de força animal em detrimento do uso exclusivo de força mecânica, também representa uma forma de tecnificação. Em sendo assim, poder-se-á compartimentar a modernização da agropecuária pernambucana em duas dimensões, estando em uma subjacente a 
tecnificação moderna e, em outra, a de cunho tradicional, possivelmente associada ao estabelecimento familiar. Entretanto, em cada dimensão, deve existir, também, o uso combinado das forças mecânica e animal, embora prevaleça um dos tipos - animal, mecânica, humana - ou, pelo menos, enquanto tendência, nas várias unidades microrregionais.

Em resumo, tomando-se o Fator 4 como medida de atraso, observa-se a existência de tendência de modernização em praticamente todas as microrregiões, dadas as variações negativas dos valores do fator, tendo-se como referência o período 1950/80. Quer dizer, haveria ocorrido o afastamento crescente em relação ao uso simultâneo de assalariados e relações de trabalho não-modernizadas, à ociosidade das terras e à escassa utilização das forças mecânica e animal e de insumos tais como adubos, corretivos defensivos, sementes e mudas. Em outras palavras, maior utilização de assalariados, sem o concurso de parceiros e agregados, maior aproveitamento produtivo das terras disponiveis, uso crescente de tração mecânica e animal, em detrimento do emprego exclusivo de força humana nos trabalhos agrários, e utilização intensiva de insumos químico-biológicos. Recorde-se que essa tendência generalizada de modemização também foi indicada pelas variações, neste caso específico, positivas, dos valores do Fator 3 para o período.

\subsection{Análise estática da modernização agrícola no Estado de Pernambuco segundo dados de $1995 / 1996$}

A partir da matriz $15 \times 32$ referente aos 32 indicadores de modernização observados em 13 microrregiões homogêneas e 2 mesorregiões, segundo dados do IBGE extraídos do Censo Agropecuário de 1995/96, foi calculada a matriz de correlações simples (32 x 32) entre os indicadores, com base na qual, foram identificadas 6 raizes características com valores superiores a 1 . 
Com o propósito de facilitar a análise dos resultados, optou-se por utilizar apenas três fatores. Além disso, levou-se em consideração o fato de que tenham captado, em conjunto, uma proporção significativa da variância total das variáveis originais: $73,83 \%$. Conforme se pode visualizar na tabela 7.14 , o primeiro fator, isto é, a combinação linear das variáveis originais que pode explicar individualmente a maior parcela da variância, captou $45 \%$ da variância; o segundo, em ordem de contribuição para a variância total, $19 \%$, e o terceiro, $9 \%$.

Tabela 7.14. Raizes características da matriz de correlações simples $(32 \times 32)$ para as microrregiões homogêneas e mesorregiões do Estado de Pernambuco, 1995/1996.

\begin{tabular}{cccc}
\hline \multirow{2}{*}{ FATORES } & RAIZ & \% DA & \% ACUMULADO \\
& CARACTERISTICA & VARIÂNCIA & AC,49 \\
\hline 1 & 14,5579 & 45,49 & 64,50 \\
2 & 6,0819 & 19,01 & 73,83 \\
3 & 2,9853 & 9,33 & 81,86 \\
4 & 2,5716 & 8,04 & 87,51 \\
5 & 1,8050 & 5,64 & 91,50 \\
6 & 1,2786 & 4,00 & 94,45 \\
7 & 0,9425 & 2,95 & 96,36 \\
8 & 0,6112 & 1,91 & 97,46 \\
9 & 0,3529 & 1,10 & 98,45 \\
10 & 0,3166 & 0,99 & 99,10 \\
11 & 0,2089 & 0,65 & 99,62 \\
12 & 0,1655 & 0,52 & 99,85 \\
13 & 0,0751 & 0,23 & 100,00 \\
14 & 0,0471 & 0,15 & 100 \\
\hline Total & $32 *$ & 100 & \\
\hline
\end{tabular}

Fonte: Dados da pesquisa obtidos através do SAS

* ordem da matriz

Objetivando-se melhorar a leitura e a interpretação dos três fatores, foi realizada uma rotação ortogonal através do método Varimax. Note-se que o total da 
variância explicada pelos três fatores, em conjunto, continuou o mesmo, antes e após a rotação ( $73,83 \%$ ), como pode ser observado na tabela 7.15 .

Tabela 7.15. Percentagem da variância explicada por cada fator antes e após a rotação ortogonal.

\begin{tabular}{lcc}
\hline Fatores & Antes da rotação (\%) & Após a rotação (\%) \\
\hline Fator 1 & 45,49 & 37,46 \\
Fator 2 & 19,01 & 21,84 \\
Fator 3 & 9,33 & 14,53 \\
Total & 73,83 & 73,83 \\
\hline
\end{tabular}

Fonte: Dados da pesquisa obtidos através do SAS.

O Fator 1 passou a captar uma proporção menor da variância total das variáveis originais. Entretanto, o poder explicativo do Fator 2 e, principalmente do Fator 3, aumentou sensivelmente, conforme pode ser visualizado na tabela 7.15.

Na tabela 7.16, estão apresentadas as cargas fatoriais ou coeficientes de correlação entre cada fator e cada um dos 32 indicadores de modemização, as comunalidades - proporção da variância de cada indicador explicada pelos três fatores em conjunto-, e, também, a proporção da variância das variáveis originais explicada por cada um dos três fatores, após a rotação pelo método varimax. Os valores superiores a 0,5 , referentes às cargas fatoriais, foram arbitrados como expressão de forte associação entre o fator e o indicador, e por isso, de modo a facilitar sua identificação, encontram-se apresentados em negrito. 
Tabela 7.16. Coeficientes de correlação (cargas fatoriais), comunalidades e percentagem da variância explicada por cada fator após a rotação pelo método Varimax, na extração de três fatores em 32 indicadores. Microrregiões Homogêneas e Mesorregiões* do Estado de Pernambuco, 1995/96.

\begin{tabular}{|c|c|c|c|c|}
\hline \multirow{2}{*}{ Indicadores de modernização } & \multicolumn{3}{|c|}{ Coeficiente de Correlação } & \multirow{2}{*}{ Comunalidade } \\
\hline & Fator 1 & Fator 2 & Fator 3 & \\
\hline $\mathrm{X} 1=\%$ estabelecimentos que usam força mecânica & $-0,678$ & 0,269 & $-0,239$ & 0,589 \\
\hline$X 2=\%$ estabelecimentos que usam força animal & $-0,776$ & 0,033 & 0,031 & 0,604 \\
\hline X3 = número de tratores / área trabalhada (AT) & 0,329 & $\mathbf{0 , 5 1 7}$ & 0,125 & 0,391 \\
\hline X4 = número de tratores / equivalente- homem & 0,435 & $\mathbf{0 , 8 2 4}$ & $-0,176$ & 0,900 \\
\hline X5 = número de arados de tração mecânica / (AT) & $-0,206$ & $\mathbf{0 , 7 5 6}$ & 0,033 & 0,615 \\
\hline X6 = número de arados de tração animal / (AT) & $-0,824$ & 0,103 & 0,151 & 0,713 \\
\hline$X 7=\%$ de estabelecimentos que usam fertilizantes & 0,795 & 0,233 & 0,019 & 0,687 \\
\hline $\mathrm{X} 8=\%$ dos estabelecimentos que usam assist. técnica & 0,322 & $\mathbf{0 , 8 0 4}$ & $-0,295$ & 0,837 \\
\hline X9 = valor dos Inanciamentos $/$ área explorada & 0,257 & 0,552 & $-0,071$ & 0,375 \\
\hline $\mathrm{X} 10=$ valor dos financiamentos / equivalente-homem & $-0,161$ & 0,638 & $-0,163$ & 0,460 \\
\hline X11 = valor dos investimentos / área explorada & 0,643 & $-0,139$ & 0,616 & 0,812 \\
\hline $\mathrm{X} 12$ = valor dos investimentos / equivalente-homem & 0,238 & 0,230 & 0,740 & 0.657 \\
\hline$X 13$ = valor da produção / área explorada & 0,946 & 0,239 & 0,153 & 0,975 \\
\hline $\mathrm{X} 14$ = valor da produção / equivalente-homem & 0,746 & 0,609 & 0,120 & 0,941 \\
\hline X15 = despesa total da produção / área explorada & 0,903 & 0,375 & 0,141 & 0,976 \\
\hline X16 = despesa total da produção / equivalente-homem & 0,734 & 0,631 & 0,120 & 0,951 \\
\hline $\mathrm{X} 17=\%$ das despesas com salánios / despesa total & 0,425 & 0,052 & $-0,813$ & 0,844 \\
\hline $\begin{array}{l}\mathrm{X} 18=\% \text { de despesas com adubos, corretivos, sementes, } \\
\text { mudas, agrotoxicos e alim. e trato animais / despesa total } \\
\mathrm{X} 19=\text { despesas com adubos corretivos, sementes, mudas, }\end{array}$ & 0,081 & $-0,348$ & 0,794 & 0,758 \\
\hline agrotóxicos e alim. e trato animais / área explorada & $\mathbf{0 , 8 6 2}$ & 0,265 & 0,375 & 0,954 \\
\hline $\begin{array}{l}\mathrm{X} 20 \text { = despesas com adubos corretivos, sementes, mudas, } \\
\text { agrotóxicos e alim. e trato animais / equivalente-homem } \\
\mathrm{X} 21 \text { = despesas com energia elétrica e combustiveis }\end{array}$ & 0,688 & 0,504 & 0,417 & 0,902 \\
\hline / área explorada & 0,768 & 0,215 & 0,409 & 0,804 \\
\hline X22 = despesas com medicamentos e alimentação & & & & \\
\hline dos animais/ área de pastagens & $\mathbf{0 , 7 3 8}$ & 0,350 & 0,282 & 0,746 \\
\hline X23 = \% da área com pastagens / área explorada & $-0,463$ & $-0,543$ & 0,492 & 0,751 \\
\hline $\mathrm{X} 24=\%$ da área $\mathrm{cl}$ pastagens plantadas $/$ área pastagens & $-0,100$ & $-0,295$ & $-0,248$ & 0,158 \\
\hline$X 25=\%$ da área de lavouras / área explorada & 0,917 & 0,245 & $-0,237$ & 0,957 \\
\hline $\mathrm{X} 26=\%$ das terras produtivas não-utilizadas & & & & \\
\hline / área aproveitável & $-0,254$ & 0,217 & $-0,644$ & 0,526 \\
\hline X27 = \% da área imigada / área trabalhada & 0,174 & $\mathbf{0 , 8 0 5}$ & $-0,103$ & 0,688 \\
\hline $\mathrm{X} 28$ = total de pessoal ocupado $(\mathrm{EH}) /$ área explorada & 0,630 & $-0,442$ & 0,176 & 0,622 \\
\hline $\mathrm{X} 29=\%$ de empregados temporários / pessoal ocupado & $\mathbf{0 , 7 1 9}$ & 0,394 & $-0,445$ & 0,870 \\
\hline$X 30=\%$ de empregados permanentes pessoal ocupado & 0,787 & 0,497 & $-0,272$ & 0,940 \\
\hline X31 = \% de mão-de-obra familiar / pessoal ocupado & $-0,746$ & $-0,481$ & 0,378 & 0,930 \\
\hline$X 32=\%$ de parceiros e outra condição/ pessoal ocupado & 0,106 & 0,594 & $-0,569$ & 0,687 \\
\hline \% da variância explicada pelo fator após a rotação............ & $. .37,46$ & 21,84 & 14,53 & \\
\hline
\end{tabular}

Fonte: Dados do IBGE, Censo Agropecuánio 1995/96 (PE), processados através do SAS.

* mesorregiões Recife e Sertão Pernambucano do São Francisco. 
Tomando-se os dados da tabela 7.16, classificou-se os coeficientes de correlação ou cargas fatoriais em 6 grupos ou intervalos de valores absolutos, como está apresentado na tabela 7.17 .

A maior parte das cargas fatoriais referentes a cada um dos três fatores (F1, F2 e F3) é positiva, respectivamente, cerca de $72 \%, 81 \%$ e $59 \%$. Ou seja, esses fatores, em princípio, guardam relação favorável com os indicadores de modernização, podendo-se estabelecer estruturas bastante características do processo.

O Fator 1 é a dimensão pela qual se pode extrair a principal medida de modernização, haja vista que $43,8 \%$ das cargas fatoriais são positivas e elevadas.

A segunda dimensão, expressa pelo Fator 2, apresenta, em sua maior parte, correlações positivas , porém fracas (47\%). Contudo, os $34 \%$ de coeficientes de correlação positivos, que variam de forte a moderado, são suficientes para estabelecer uma segunda estrutura característica do processo.

Tabela 7.17. Percentagem de grupos de variáveis segundo o grau de correlação entre cada fator e a variável.

\begin{tabular}{|c|c|c|c|c|}
\hline $\begin{array}{c}\text { Grau de Correlação do } \\
\text { Fator }\end{array}$ & $\begin{array}{c}\text { Intervalo } \\
\text { (valores absolutos) }\end{array}$ & $\begin{array}{c}\text { Fator } 1 \\
(\%)\end{array}$ & $\begin{array}{c}\text { Fator } 2 \\
(\%)\end{array}$ & $\begin{array}{c}\text { Fator } 3 \\
(\%)\end{array}$ \\
\hline positivo e forte & $(0,6$ e mais $)$ & 43,8 & 21,9 & 9,4 \\
\hline positivo e moderado & $(0,5$ a menos de 0,6$)$ & 0 & 12,5 & 0 \\
\hline positivo e fraco & $($ menos de 0,5$)$ & 28,1 & 46,9 & 50,0 \\
\hline negativo e forte & (0,6 e mais) & 12,5 & 0 & 6,2 \\
\hline negativo e moderado & $(0,5$ a menos de 0,6$)$ & 0 & 3,1 & 3,1 \\
\hline negativo e fraco & (menos de 0,5$)$ & 15,6 & 15,6 & 31,3 \\
\hline Total & & 100,0 & 100,0 & 100,0 \\
\hline
\end{tabular}

Fonte: Classificação elaborada pela pesquisa a partir dos dados processados através do SAS.

O terceiro fator (F3), semelhantemente ao Fator 2, também se mostra associado positiva e fracamente com a maior parte dos indicadores $(50 \%)$ : apenas $9 \%$ das cargas fatoriais são positivas e fortes. Contudo, os coeficientes positivos representam $60 \%$ do total. Em suma, o Fator 3 está exprimindo mais sinonímia em relação ao processo, isto é, concordância com a maior parte dos indicadores, do que antagonismo. 
Em sendo assim, essa terceira dimensão também está representando alguma das faces do processo.

De maneira geral, o objetivo da rotação foi alcançado com sucesso: as correlações, para os três fatores, tornaram-se com maior frequência, relativamente fortes ou relativamente fracas. Para todos os fatores prevalecem, como já observado, as correlações positivas. Em consequência, as correlações positivas e fortes indicarão bem acentuadamente, em seu conjunto, o significado de cada fator. Para nenhum fator houve a prevalência de correlações de valores moderados, isto é, nem muito fracas ou nem muito fortes.

O passo seguinte foi o de confirmar se essa quantidade inicial de fatores seria a mais adequada para explicar ou captar, em conjunto, proporção significativa da variância de cada variável. Ou, de outra parte, que pelo menos a maior parte das variáveis estivesse associada fortemente a algum dos três fatores. Essa investigação foi procedida analisando-se as comunalidades e as cargas fatoriais.

Através dos valores das comunalidades listadas na tabela 7.16, avaliouse, então, a capacidade explicativa conjunta dos três fatores em relação a cada indicador. Observa-se que dos 32 indicadores, os três fatores explicariam conjuntamente grande parte da variância total de pelo menos 28 , ou cerca de $87 \%$ do total. Outros quatro não estão bem captados, apresentando comunalidade inferior a 50\%: X3 (número de tratores / área trabalhada), X9 (valor dos financiamentos / área explorada), X10 (valor dos financiamentos / equivalente-homem) e X24 (percentagem da área com pastagens plantadas / área de pastagens), respectivamente: 0,$391 ; 0,375 ; 0,460 ;$ e 0,158 .

Note-se, também, que o indicador X24, que apresenta a comunalidade de valor mais baixo, não está associado forte ou moderadamente a nenhum dos três fatores, considerando-se cargas fatoriais superiores a 0,5. Ao contrário, o indicador X10 acha-se forte e positivamente $(0,638)$ associado ao Fator 2 . Também a esse fator, encontram-se associados positiva e moderadamente os indicadores X3 $(0,517)$ e X9 $(0,552)$.

Por outro lado, mencionem-se X1 (percentagem dos estabelecimentos com indicação de uso de força mecânica) e X26 (percentagem das terras produtivas não- 
utilizadas / área aproveitável), cujas respectivas comunalidades situam-se entre 0,5 e 0,6, indicando que o conjunto de três fatores explicaria moderadamente as variâncias desses indicadores.

Em nível de teste, em razão das baixas comunalidades apresentadas pelo conjunto de três fatores para $\mathrm{X} 3, \mathrm{X} 9, \mathrm{X} 10$ e $\mathrm{X} 24$, efetuou-se uma análise fatorial extraindo-se quatro fatores. Constatou-se que, após a rotação, para X9 e, principalmente, para X24, ainda ocorria comunalidade de valor baixo: 0,44 e 0,26 , respectivamente. Entretanto, para $\mathrm{X} 3$ e $\mathrm{X} 10$, as comunalidades passaram de valores baixos a fortes: 0,79 e 0,60 .

Analisando-se as cargas fatoriais, constatou-se que $\mathrm{X} 3$ e $\mathrm{X} 9$ apresentaram forte e positiva associação com o Fator 1, e X10, moderada e negativa associação com o Fator 2. Todavia, o problema continuou a persistir para X24. Ou seja, a comunalidade manteve-se baixa e, além disso, todos os quatro fatores apresentaram correlação fraca com esse indicador.

$\mathrm{Na}$ seqüência de testes, foram extraídos cinco fatores. Como resultado, apenas para X24 ainda continuava a ocorrer uma comunalidade de baixo valor: 0,46 . Também, nenhum fator associou-se forte ou moderadamente ao indicador. De uma maneira geral, excetuando X24, todos os demais revelaram-se estar associados forte ou moderadamente aos fatores.

Procedendo-se a análise fatorial através da extração de seis fatores, justamente o total associado às raizes características maiores que a unidade, observou-se nos dados rotacionados, que todas as comunalidades são bastante elevadas, indicando que apenas seis fatores são adequados para captar parcelas expressivas da variância de praticamente todos os 32 indicadores.

A comunalidade referente a X24 tornou-se elevada $(0,839)$, além de o indicador revelar-se forte e positivamente associado ao Fator 6. Entretanto, conhecida a solução para o indicador, isto é, a extração de 6 fatores, o sexto fator mostrou-se desprezivel do ponto de vista de acrescer significativamente uma dimensão apreciável do processo, por dois motivos: o primeiro, por ter captado, mesmo após a rotação, apenas 
$5,2 \%$ da variância das variáveis originais; em segundo, por mostrar-se associado forte e positivamente apenas ao próprio X24. Em razão disso, pouco seria acrescentado à análise.

Restaria decidir entre a extração de 3, 4 ou 5 fatores. Apesar de um maior número de fatores conseguir captar em conjunto parcela mais expressiva da variância, optou-se por permanecer com apenas três, pois revelaram-se suficientes para o trabalho proposto. Além disso, fatores adicionais passam a explicar, tomados isoladamente, proporções cada vez menores da variância dos indicadores originais ${ }^{23}$. Ou seja, o acréscimo de 4 ou 5 fatores dificultaria a análise das estruturas, pois fragmentaria ainda mais o total da variância explicada. Levou-se também em consideração um critério mais empírico que foi o de reter determinada quantidade de fatores, que após a rotação, pudesse ser interpretável de modo coerente. Como se observou na extração de 3 fatores, apesar das comunalidades serem relativamente baixas para $X 3, X 9$ e $X 10$, esses indicadores apresentaram-se razoavelmente associados ao Fator 2, satisfazendo os propósitos do trabalho.

A análise das cargas fatoriais a seguir, de acordo com os dados apresentados na tabela 7.16, vai fornecer uma interpretação específica ou significado de cada fator.

Considerando-se a análise fatorial através da extração de três fatores temse que o primeiro fator (F1) está forte e positivamente correlacionado com $X 7$ (percentagem dos estabelecimentos com indicação de uso de fertilizantes), X11 (valor dos investimentos / área explorada), X13 (valor da produção agropecuária (animal e vegetal) / área explorada), X15 (valor da despesa total da produção / área explorada), X19 (valor das despesas com adubos, corretivos, sementes, mudas, agotóxicos medicamentos e alimentação dos animais / área explorada), X21 (valor das despesas com energia elétrica, combustíveis e lubrificantes / área explorada), X22 (valor das despesas com medicamentos e alimentação dos animais / área de pastagens), X25 (percentagem da

\footnotetext{
${ }^{23} \mathrm{Na}$ análise fatorial extraindo-se seis fatores, a proporção da variância explicada por esse conjunto de fatores è de $91,5 \%$. Porém a variância explicada por cada fator decresce sucessivamente: Fator $1(45,49 \%)$, Fator 2 (19,01\%), Fator $3(9,33 \%)$, Fator $4(8,04 \%)$, Fator $5(5,64 \%)$ e Fator $6(4,00 \%)$.
} 
área de lavouras / área explorada) e X28 (total de pessoal ocupado (EH) / área explorada). Esse conjunto de indicadores está caracterizando a intensidade de exploração da terra.

O Fator 1 também se mostra positiva e fortemente associado aos indicadores X14 (valor da produção agropecuária / equivalente-homem), X16 (valor da despesa total da produção / equivalente-homem), X20 (valor das despesas com adubos, corretivos, sementes, mudas, agrotóxicos, medicamentos e alimentação dos animais / equivalente-homem). Ou seja, o Fatorl está indicando também aumento da relação capital-trabalho, pelo lado da utilização de insumos químico-biológicos.

Analisando-se as cargas fatoriais relativas aos indicadores das categorias de mão-de-obra, constata-se que F1 está forte e positivamente associado a X29 (percentagem de empregados temporários / total de pessoal ocupado em equivalentehomem) e a X30 (percentagem de empregados permanentes / total de pessoal ocupado em equivalente-homem), e forte e negativamente associado ao trabalho familiar (X31). Quer dizer, o Fatorl também está assinalando a modernização das relações de trabalho.

$\mathrm{O}$ Fator ainda se mostra forte e negativamente associado a Xl (percentagem dos estabelecimentos com indicação de uso de força mecânica), X2 (percentagem dos estabelecimentos com indicação de uso de força animal) e X6 (número de arados de tração animal / área trabalhada).

Quer dizer, o Fator 1 exclui a utilização de força animal, tanto em termos de disseminação (X2), quanto em termos de seu uso intensivo por unidade de área (X6). Por outro lado, Xl está revelando não existir, também, forte disseminação de força mecânica, apesar de ocorrer o uso intensivo de tratores, em face da associação positiva, embora fraca, ao indicador X3 (0,329).

Em resumo, o Fator 1 será interpretado com medida de modemização, na qual estão reunidas simultaneamente tanto a intensidade da exploração da terra, em termos do uso intensivo de tecnologias por unidade de área, quanto a relação capitaltrabalho, isto é, o emprego de tecnologias por unidade de mão-de-obra ocupada. 
O Fator 2 está associado forte e positivamente a X5 (número de arados de tração mecânica / área trabalhada), X9 (valor dos financiamentos / área explorada), X27 (percentagem da área irrigada / área trabalhada). Revela-se ainda moderadamente associado a X3 (número de tratores / área trabalhada). Esses indicadores estão revelando a intensidade de exploração da terra.

Esse segundo fator também está associado forte e positivamente a X4 (número de tratores / equivalente-homem), X10 (valor dos financiamentos / equivalentehomem), X14 (valor da produção / equivalente-homem) e X16 (despesas total da produção / equivalente-homem). O Fator 2 , em função desse conjunto específico de indicadores, pode ser interpretado como aumento da relação capital trabalho.

O Fator 2 associa-se forte e positivamente ao conjunto de estabelecimentos que receberam assistência técnica (X8). Mostra-se, também, moderadamente associado a X32 (percentagem de parceiros e outra condição / total de pessoal ocupado em equivalente-homem) e fraca e positivamente ao trabalho assalariado temporário (X29) e ao permanente (X30).

A dimensão F2 será interpretada como uma medida do grau de mecanização e assistência técnica associadas à irrigação.

À primeira vista, os dois fatores anteriores apresentam semelhanças, pois ambos estão medindo a modernização. Porém, a primeira dimensão está captando o fenômeno mais em termos das inovações químico-biológicas, enquanto que a segunda estrutura, principalmente pelo lado da mecanização e utilização de inovação fisica: a irrigação. Dessemelhanças existem também quanto à utilização de mão-de-obra: o Fator 1 está bem associado aos indicadores concementes ao trabalho assalariado, tanto permanente quanto temporário. Ao associar-se positiva e fortemente a X28 (total de pessoal ocupado / área explorada), revela existir intensidade de uso do trabalho humano por unidade de área. Diferentemente, F2 está associado moderada e negativamente a X28. Por outra parte, associa-se de forma positiva ao trabalho de parceiros e pessoal de outra condição, e moderadamente ao trabalho assalariado permanente e temporário. Por refletir predominantemente aspectos relacionados à mecanização, em consequência, essa 
estrutura (F2) evidencia um peso menor para os indicadores relacionados à mão-de-obra, opostamente ao que revela o Fator 1.

O Fator 3 está forte e positivamente correlacionado com : X11 ( valor dos investimentos / área explorada), X12 (valor dos investimentos / equivalente-homem) e X18 (percentagem do valor das despesas com adubos, corretivos, sementes, mudas, agrotóxicos, medicamentos e alimentação dos animais / valor da despesa total). Paralelamente, apresenta forte associação negativa com X17 (percentagem do valor das despesas com salários / valor da despesa total) e X26 (percentagem das terras produtivas não-utilizadas / área aproveitável). Além disso, revelou moderada associação negativa ao indicador referente à participação das categorias parceiro e pessoal de outra condição (agregados, moradores, etc.) no total de pessoal ocupado (X32). De outra parte, a associação inversa entre X17 (-0,813) e X18 (0,794) está indicando uma estrutura representativa de explorações embasadas mais na utilização de insumos do que na de mão-de-obra assalariada, dado que F3 também é negativamente associado ao trabalho temporário (X29) e ao permanente (X30), ou mesmo da categoria "parceiros e outra condição $(X 32=-0,569)$. Porém, associa-se positivamente, embora de forma fraca, ao trabalho familiar $(\mathrm{X} 31=0,378)$.

Em resumo, essa dimensão está indicando um conjunto de explorações que utiliza preponderantemente trabalho familiar em detrimento de mão-de-obra contratada. Em sendo assim, sua principal rubrica de despesas são os insumos $(\mathrm{X} 18=$ $0,794)$ e não os salários $(X 17=-0,813)$. Além disso, são explorações que utilizam intensivamente a terra, tanto em termos dos insumos nela empregados, quanto pela pressão sobre esse recurso, haja vista sua baixa ociosidade revelada por X26 $(-0,644)$. Está ainda associada mais à pecuária $(X 23=0,492)$ do que às lavouras $(X 25=-0,237)$. O Fator 3 será interpretado como investimentos e utilização de insumos modernos, com ênfase em áreas de pecuária.

Através da tabela 7.18, apresentam-se os valores dos fatores segundo 13 microrregiões homogêneas e duas mesorregiões de Pernambuco, para 1995/96. As 
unidades de observação acham-se listadas em três grandes blocos, segundo as tradicionais mesorregiões: Mata, Agreste e Sertão.

Tabela 7.18. Valores do fatores, segundo microrregiões homogêneas e mesorregiões, na análise fatorial em 32 indicadores. Pernambuco, 1995/96.

\begin{tabular}{lccc}
\hline Microrregião Homogênea & Fator $\mathbf{1}(\mathbf{a})$ & Fator 2 (b) & Fator 3 (c) \\
\hline Recife* & $\mathbf{2 , 0 1 1}$ & $\mathbf{0 , 8 2 2}$ & $\mathbf{0 , 8 7 0}$ \\
Mata Seca** $^{*}$ & $\mathbf{1 , 2 0 5}$ & $\mathbf{1 , 6 4 9}$ & $-0,362$ \\
Mata Úmida*** $^{*}$ & $\mathbf{1 , 0 9 2}$ & $-0,058$ & $-2,606$ \\
Vitória de Santo Antão & $\mathbf{1 , 1 3 7}$ & $-0,661$ & $\mathbf{0 , 0 6 0}$ \\
\hline Vale do Ipanema & $-0,570$ & $-0,694$ & $\mathbf{0 , 4 9 1}$ \\
Alto Capibaribe & $-0,042$ & $-0,658$ & $\mathbf{0 , 3 2 0}$ \\
Médio Capibaribe & $\mathbf{0 , 6 2 1}$ & $-1,479$ & $\mathbf{0 , 2 1 2}$ \\
Brejo Pernambucano & $\mathbf{0 , 0 4 2}$ & $-0,304$ & $\mathbf{0 , 9 8 5}$ \\
Garanhuns & $-0,355$ & $-0,755$ & $\mathbf{0 , 4 1 6}$ \\
Vale do Ipojuca & $-0,116$ & $\mathbf{0 , 3 9 9}$ & $\mathbf{1 , 7 4 4}$ \\
\hline Araripina & $-0,829$ & $-0,584$ & $-1,015$ \\
Salgueiro & $-0,949$ & $-0,124$ & $-0,783$ \\
Sertão do São Francisco* & $-1,281$ & $\mathbf{2 , 4 1 6}$ & $-0,034$ \\
Sertão do Moxotó & $-1,026$ & $\mathbf{0 , 1 7 1}$ & $-0,313$ \\
Alto Pajeú & $-0,941$ & $-0,140$ & $\mathbf{0 , 0 1 5}$ \\
\hline \hline
\end{tabular}

Fonte: Dados do IBGE, Censo Agropecuário de 1995/96 (PE), processados através do SAS.

(a) Modernização; (b) Mecanização e assistência técnica associadas à irrigação; (c) investimentos e utilização de insumos modernos, com ênfase em áreas de pecuária.

* mesorregiōes; ** refere-se à microrregião Mata Setentrional; *** refere-se à microrregião Mata \$leridional.

O primeiro fator é a principal medida de modemização, ao ter captado, após a rotação varimax, $37 \%$ da variância das variáveis originais. Além disso, apresentou correlações positivas com cerca de $72 \%$ do total de 32 indicadores. Ainda considerandose esse total, F1 associou-se positiva e fortemente a $43 \%$, propiciando uma interpretação bem clara do fenômeno.

As unidades de observação com os valores positivos mais elevados localizam-se na zona canavieira, principalmente a mesorregião Recife $(2,011)$, secundada pelas microrregiões Mata Seca $(1,205)$, Vitória de Santo Antão $(1,137)$ e Mata Úmida $(1,092)$. As demais microrregiões que apresentaram valores positivos localizam-se na mesorregião Agreste: Médio Capibaribe $(0,621)$ e Brejo Pernambucano, com valor 
próximo da média $(0,042)$, ambas situadas em partes de antigas micorregiões homogêneas: a primeira, no Agreste Setentrional, e a segunda, no Agreste Meridional.

As demais microrregiões do Agreste apresentaram valores negativos. Contudo, comparativamente, os valores negativos de todas unidades de observação localizadas na mesorregião Sertão $(-0,829$ a $-1,281)$, são inferiores aos apresentados pelas unidades do Agreste $(-0,042$ a -0.570$)$. Isto indicaria que, considerando-se a modernização representada por $\mathrm{Fl}$, os níveis do processo estão melhor posicionados no Agreste do que no Sertão, embora ambas mesorregiões aquém da zona canavieira. Essa constatação reconfinna a hipótese de que a modemização no estado perderia intensidade no sentido leste-oeste, ou litoral-interior.

No Agreste, a partir dos valores negativos, pode-se estabelecer subníveis de modernização: a microrregião pior posicionada é o Vale do Ipanema (ex-MRH Arcoverde) - com o valor inferior às demais (-0,570) -, seguida das MRHs Garanhuns (0,355), Vale do Ipojuca $(-0,116)$, e finalmente, com valor próximo da média, o Alto Capibaribe $(-0,042)$.

Embora as microrregiões do Censo 1995/96 não sejam exatamente as mesmas dos Censos anteriores, pode-se fazer algumas considerações, tomando-se as antigas microrregiões como referência. A microrregião Agreste Setentrional, subdividida que foi em duas unidades, está revelando um espaço mais moderno (Médio Capibaribe) e outro mediano (Alto Capibaribe); já no Agreste Meridional, a oposição é mais acentuada entre o mais modemo, embora com valor mediano, (Brejo Pernambucano), e o menos moderno (Garanhuns). A microrregião Vale do Ipojuca manteve-se a mesma, em termos de comparabilidade entre os Censos, tendo-se situado em subnível melhor que a microrregião anterior

As unidades geográficas mais atrasadas, no que se refere à dimensão especifica da modemização intrínseca ao Fator 1, localizam-se na mesorregião Sertão, todas com valores negativos bem expressivos e bastante próximos: Sertão do São Francisco $(-1,281)$, Sertão do Moxotó $(-1,026)$, Salgueiro $(-0,949)$, Alto Pajeú $(-0,941)$ e Araripina $(-0,829)$. 
Considerando-se outra face da modemização subjacente, desta feita em F2, isto é, a mecanização e assistência técnica associadas à imigação, tem-se que apenas duas unidades de observação, reveladas modernizadas por F1, também apresentaram valor positivo através de F2: a mesorregião Recife $(0,822)$ e a microrregião Mata Seca $(1,649)$. A Mata Úmida exibiu valor negativo, porém próximo e abaixo da média (0,058). As demais unidades de observação com valor positivo para o Fator 2 são: na mesorregião Sertão, a mesorregião Sertão do São Francisco $(2,416)$ e a microrregião Sertão do Moxotó $(0,171)$, e no Agreste, a microrregião Vale do Ipojuca $(0,399)$.

A mesorregião Recife e a microrregião Mata Seca estão revelando uma modemização mais consistente, pois, considerando-se as duas principais dimensões da modemização, F1 e F2, essas unidades de análise se encontram significativamente posicionadas com valores bem acima da média. Analisando-se a questão, a partir da soma dos escores de F1 e F2, constatam-se valores em torno de 2,8 para as duas unidades mencionadas. Seguem-se-lhes o Sertão do São Francisco $(1,1)$, a Mata Úmida $(1,0)$ e Vitória de Santo Antão $(0,48)$.

Em relação à mesorregião Sertão do São Francisco, que apresentou o valor mais alto para F2, como mencionado, revela uma dualidade tecnológica muito grande; abriga a moderna e dinâmica agricultura irrigada ao longo do Rio São Francisco ao lado de um setor tradicional, de sequeiro, basicamente a policultura alimentar de subsistência associada à pecuária extensiva. Isso explicaria, em parte, o valor negativo de F1 ao lado do alto valor positivo de F2.

$\mathrm{O}$ terceiro fator (F3), segundo a interpretação realizada com base nos coeficientes de correlação entre o fator e cada indicador, está representando principalmente os investimentos e a utilização de insumos modernos, com ênfase em áreas de pecuária. Está refletindo também áreas de baixa ociosidade do recurso terra e de importância relativa da mão-de-obra familiar.

$\mathrm{Na} z o n a$ canavieira, apresentam valores positivos a mesorregião Recife $(0,870)$ e a microrregião Vitória de Santo Antão $(0,060)$, cujo valor situa-se próximo e ligeiramente acima da média. Na mesorregião Agreste, todos os valores são positivos, 
sendo o Vale do Ipojuca, a microrregião melhor posicionada $(1,744)$, seguida pelo Brejo Pernambucano $(0,985)$, Vale do Ipanema $(0,491)$, Garanhuns $(0,416)$, Alto Capibaribe $(0,320)$ e Médio Capibaribe $(0,212)$. Considerando-se as antigas microrregiões, o Agreste Meridional (Brejo Pernambucano e Garanhuns) estaria melhor posicionado que o Agreste Setentrional (Alto e Médio Capibaribe). Ressalte-se que a estrutura representada pelo Fator 3, em razão de estar refletindo positivamente, embora fracamente, a mão-de-obra familiar $(\mathrm{X} 31=0,378)$, inclusive no aspecto de intensidade $(\mathrm{X} 28=0,176)$, concomitantemente ao uso de força animal (X2 e X6), posiciona, favoravelmente, todas as microrregiões do Agreste: nessa mesorregião há predomínio dos minifúndios, e da pequena propriedade de modo geral, apesar de existir concentração fundiária; e a terra é explorada intensivamente, pelo trabalho do "responsável e membros não remunerados da família". Trata-se, além disso, de região em que ocorreu forte processo de avanço da pecuária.

Na mesorregião Sertão, apenas a microrregião Alto Pajeú apresentou valor positivo, porém baixo $(0,015)$ : em outras palavras, está posicionada acima e próxima da média. Opostamente, a mesorregião Sertão do São Francisco está posicionada abaixo e próxima da média $(-0,034)$.

O Fator 3 apresenta algumas semelhanças com os resultados da análise dinâmica. Considere-se inicialmente os valores do Fator 2 (pecuária melhorada em áreas de predomínio de lavouras), obtidos para 1980: os escores mostraram-se positivos para as microrregiões da Mata, Agreste e, no Sertão, apenas para o Alto Pajeú. Nesta análise estática, para 1995/96, também para esses espaços os valores revelaram-se positivos, à exceção da Mata Seca e da Mata Úmida, que apresentam escores negativos. Há que se considerar que os fatores não são exatamente os mesmos, nem as unidades de análise, nem o periodo investigado. Contudo, os valores positivos de F2 (1980) e F3 (1995/96) de alguma forma estão corroborando a principal conclusão de ambas análises: as áreas aonde estão situadas a pecuária melhorada seriam praticamente as mesmas: todas as microrregiões do Agreste sem exceção, no Sertão, o Alto do Pajeú, e, na Mata, fundamentalmente, a mesorregião Recife. 


\section{CONCLUSÕES}

Em Pernambuco, ainda predomina uma agricultura de baixo padrão tecnológico. Entretanto, a análise fatorial revelou a existência de diferenciações relevantes entre as posições relativas de cada microrregião homogênea com referência ao processo de modernização em curso. Em 1950, as microrregiões mais modemizadas localizavam-se na zona canavieira. Além desse espaço geográfico, considerando-se a ocorrência de modernização, identificou-se o Sertão Pernambucano do São Francisco, uma exceção em meio ao contexto de baixo nível tecnológico predominante na mesorregião. Em linhas gerais, esse conjunto de microrregiões mais modernizadas manteve-se relativamente estável nas décadas seguintes.

São justamente as microrregiões que apresentaram níveis mais altos de modernização as que revelaram tendência mais acentuada de incremento desse processo, acarretando o aumento da diferenciação. Tomando-se o período 1950/80, a microrregião com mais forte tendência de modernização foi a Mata Seca. Seguem-se-lhe o Sertão do São Francisco, Recife e a Mata Úmida. A análise fatorial dinâmica, através dos valores para 1980, revelou duas outras microrregiões com sinais de modernização: o Agreste Setentrional e Salgueiro.

A tendência de desenvolvimento de um padrão mais elementar de modernização, caracterizado pela utilização da tração animal, foi identificada para o período 1950/80, para microrregiões do Agreste e do Sertão. Em oposto, na Zona da Mata, existiu tendência de afastamento em relação a esse padrão. Especificamente, foi constatada a existência de interação entre as tendências de modernização convencional (mecanização e insumos químico-biológicos) e a elementar (principalmente a tração animal), resultando em três grupamentos: microrregiões com predomínio de tendência 
de modernização convencional: as da zona canavieira e Agreste Setentrional; microrregiões com tendência equilibrada entre os dois padrões: São Francisco e Salgueiro, refletindo forte dualidade tecnológica; e microrregiões com tendência predominante de desenvolvimento de padrão elementar de tecnificação: microrregiões do Sertão e microrregiões do Agreste, excetuando-se o Agreste Setentrional.

Entretanto, considerando-se o padrão mais evoluído de modernização, todas as microrregiões apresentaram variações positivas. Mas, essa tendência foi bem menos acentuada para a microrregião agrestina de Arcoverde e as microrregiões sertanejas Moxotó e Alto Pajeú. Ao contrário, essas microrregiões, encabeçada pela primeira, revelaram forte tendência de incorporação de tração animal.

A análise dinâmica também revelou uma estrutura relativa ao desenvolvimento da pecuária melhorada no Estado. Grosso modo, à exceção de Araripina, a pecuária melhorada continuaria sendo praticada nas mesmas microrregiões, apesar de decorridos 30 anos: as microrregiões da zona canavieira e as do Agreste, e, no Sertão, apenas o Vale do Pajeú. Em termos de evolução, somente a Mata Úmida apresentou tendência favorável no período 1950/80. Entretanto, considerando-se o subperíodo 1970/80, ocorreram variações positivas para quase todas as microrregiões, indicando melhoria do padrão tecnológico da atividade.

Identificou-se outra estrutura para qual atribuiu-se o significado predominante de atraso, em face dos principais indicadores de modernização associarem-se negativamente a essa dimensão. Em linhas gerais, todas as microrregiões revelaram variações negativas para o escore fatorial, no período $1950 / 80$, indicando tendência de avanço da modernização, ou, em outras palavras, afastamento de aspectos relacionados ao atraso. As variações negativas foram bastante acentuadas na Zona da Mata. Ao contrário, as variações negativas foram mais fracas, no Agreste, para a microrregião Arcoverde, e, no Sertão, para o Alto Pajeú.

Os dados de 1995/96, utilizados em análise fatorial estática, evidenciaram niveis de modernização mais elevados para as microrregiões homogêneas da zona canavieira. Revelaram, ainda, modemização em partes das antigas microrregiões 
Agreste Setentrional e Agreste Meridional, respectivamente MRH Médio Capibaribe e MRH Brejo Pernambucano.

A modernização ainda foi identificada através de uma segunda estrưtura na qual a mecanização e assistência técnica se associaram à irrigação. Posicionou-se fortemente, nessa dimensão, o Sertão Pemambucano do São Francisco, seguido pela microrregião canavieira Mata Seca e a mesorregião Recife. Também com valores positivos, isto é, valores acima da média, porém bem menos expressivos, destacaram-se o Vale do Ipojuca e o Sertão do Moxotó.

Uma terceira estrutura de modernização, investimentos e utilização de insumos modernos com ênfase em áreas de pecuária, apresentou valores positivos para todas as microrregiões do Agreste - com escores elevados para o Vale do Ipojuca e o Brejo Pernambucano (antiga MRH Agreste Meridional) - e no Sertão, próximo da média, o Alto Pajeú. Na Zona da Mata, com notas positivas apenas a mesorregião Recife, secundada pela nova MRH Vitória de Santo Antão.

Em termos do espaço geográfico estadual, extraindo-se a microrregião onde se insere a agricultura irrigada do São Francisco, a estratificação de escores fatoriais leva a inferir que o processo de modemização perderia intensidade no sentido capital-interior. Em outras palavras, os níveis de modemização, grosso modo, posicionam melhor as microrregiões da Mata, e na seqüência, as do Agreste, e, finalmente, as do Sertão, que apresentam indices freqüentemente inferiores às demais.

Em síntese, o processo de modemização revelou-se mais intenso nas microrregiões relativamente mais modernizadas. Como resultado, tanto nos anos 1980 quanto nos anos 1990, as principais microrregiões com indícios de modernização mais consistente continuaram a ser as da Zona da Mata, em função de sua principal atividade a cana-de-açúcar, e o Sertão do São Francisco, dado o dinamismo propiciado pelo crescente uso de sistemas irrigados. Entretanto, esse quadro de modernização concentrada foi sendo paulatinamente abrandado, em decorrência de ter havido tendência generalizada de modernização nas três mesorregiões. Em conseqüência, nos anos 1990, todas as microrregiões da mesorregião Agreste apresentaram algum tipo de modernização, principalmente com base em áreas de pecuária, resultado de processo que 
fora iniciado desde os anos 1950. Mais a oeste, especificamente na mesorregião Sertão, embora a modemização se encontre bastante restrita ao São Francisco, também houve tendência favorável de disseminação do processo.

As políticas governamentais contribuíram para o atual quadro de distribuição desigual do processo de modemização, em face da concentração de recursos. Não obstante as microrregiões canavieiras haverem sido beneficiadas e se mostrarem mais modernizadas que a média, os mecanismos criados de proteção à atividade, em relação à concorrência, teriam acarretado o retardamento do ritmo adequado de modernização que seria normalmente imposto a um mercado livre. No Sertão, fundamentalmente, o fomento à irrigação ao longo do São Francisco obteve por êxito a interiorização do desenvolvimento tecnológico. Entretanto, a modernização manteve-se bastante circunscrita. Disso resultou que, mesmo dentro do próprio espaço microrregional, a dualidade tecnológica é exacerbada. Cabe destacar que o fomento às atividades irrigadas em outras áreas, no Sertão e no Agreste, produziu o estabelecimento de "enclaves modernos", insulados em contexto predominante e tecnologicamente tradicional. Diante da problemática, sugere-se o direcionamento da aplicação dos instrumentos de política, reorientando investimentos e financiamentos, no sentido de reduzir as disparidades tecnológicas, e, por decorrência, as de ordem social e econômica. Como resultado, seria elevado o nível tecnológico do setor agropecuário do estado, aumentando sua produtividade e dando-lhe maior dinamismo, para a geração de emprego e renda, possibilitando melhoria das condições de vida da população. 


\section{REFERÊNCIAS BIBLIOGRÁFICAS}

ALVES, M.C. SAS - Estatística multivariada. Piracicaba: CIAGR/ESALQ/USP, 1993. 111p. (Série Didática CIAGRI, 23).

ANDRADE, M.C. A propriedade da terra e a questão agrária em Pernambuco. In: A propriedade da terra $e$ as transformações recentes da agricultura pernambucana. Recife: Convênio UFPE/IDRC/Fundação FORD, 1982.

ANDRADE, M.P. Estrutura fundiária, modernização e distribuição de renda na agricultura matogrossense. Piracicaba, 1989. 201p. Dissertação (Mestrado) Escola Superior de Agricultura "Luiz de Queiroz", Universidade de São Paulo.

ARAÚJO, P.F.C.; SCHUH, G.E. (Coord.) Desenvolvimento da agricultura: natureza do processo e modelos dualistas. São Paulo: Pioneira, 1975. 192 p. ; Desenvolvimento econômico e agricultura. Piracicaba: ESALQ/USP, 1997

BARROS, G.S. de C. Economia da comercialização agrícola. Piracicaba: FEALQ, 1987.

BANCO CENTRAL DO BRASIL. Crédito rural: dados estatísticos, 1977-81.

BELFORT, A.F. Usinas resistem à crise. Jornal do Commércio. Caderno de Economia, Recife, 06 jun. 1999. 
BRASL. Ministério da Agricultura. Comissão Coordenadora da Política Nacional de Crédito Rural. Crédito rural: perfis de distribuição e dados estatísticos, 1969-76. Brasilia: COMCRED, 1977-78. 5v.

.INSTITUTO NACIONAL DE COLONIZAÇÃO E REFORMA AGRÁRIA. Regiões homogêneas da agricultura. Campinas: INCRA/UNICAMP, 1975. 290p.

Zoneamento agrário: $1^{\text {a }}$ fase. Brasília: INCRA/SERPRO, 1978. 140p. (Informativo técnico, n. 4).

CARVALHO, B.M.T. de S.P. de. Modemização da agricultura: análise de seis culturas no Brasil. Piracicaba, 1982. 205p. Dissertação (Mestrado) - Escola Superior de Agricultura "Luiz de Queiroz", Universidade de São Paulo.

CAST ANHEIRA, P.M. Análise fatorial como método de estratificação: uma aplicação empirica na cafeicultura. Viçosa, 1976. 67p. Dissertação (Mestrado) - Universidade Federal de Viçosa.

CODEVASF. Jornal de Irrigação. (Veículo informativo da CODEVASF). Brasilia, 1983, n.3, p. 1-8.

COMISSÃo DO VALE DO SÃO FRANCISCO. A valorização do Vale do São Francisco. Rio de Janeiro: CVSF, 1957. (Relatório da Missão Francesa enviada pela "Seção de Assistência Técnica Bilateral" do Ministério de Negócios Exteriores da França, em abril de 1956).

CONSELHO DE DESENVOLVIMENTO DE PERNAMBUCO. Relatório dos estudos sobre o potencial de exploração da Zona da Mata de Pernambuco com agriculturas de sequeiro e irrigada . Recife: SEPLAN/CONDEPE, 1991. 75p.

CUNHA, A.S. Rural poverty and agricultural modernization in Brazil. Nashville, 1978. 245p. Thesis (Ph.D. ) - Vanderbilt University. 
DANTAS, B. A agroindústria canavieira de Pernambuco: as raizes históricas dos seus problemas, sua situação atual e suas perspectivas. Recife: MINTER/GERAN, 1971. $107 \mathrm{p}$.

; SILVA, L.S. Subsídios para o programa de desenvolvimento sustentável da Zona da Mata. Recife, 1995.72p.

ESPÍRITO SANTO, E.N. do. Transformações da agricultura no Estado de Santa Catarina. Piracicaba, 1998. 197p. Tese (Doutorado) - Escola Superior de Agricultura "Luiz de Queiroz", Universidade de São Paulo.

FEI, J.C.H.; RANIS, G. Agrarianismo, dualismo e desenvolvimento econômico. In: ARAÚJO, P.F.C.; SCHUH, G.E. (Coord.). Desenvolvimento da agricultura: natureza do processo e modelos dualistas. São Paulo: Pioneira, 1975. cap.2, p.101136.

FIGUEIREDO, N.M.S. Modernização, distribuição da renda e pobreza na agricultura brasileira, 1975, 1980 e 1985. 248p. Piracicaba, 1996. Tese (Doutorado) - Escola Superior de Agricultura "Luiz de Queiroz", Universidade de São Paulo.

FUNDAÇÃO INSTITUTO BRASILEIRO DE GEOGRAFIA E ESTATÍSTICA. Censo agrícola de 1960 (Pernambuco). Rio de Janeiro: IBGE, 1966.

Censo agropecuário de 1970 (Pernambuco). Rio de Janeiro: IBGE, 1975.

Censo agropecuário de 1980 (Pernambuco). Rio de Janeiro: IBGE, 1983.

- Censo agropecuário de 1985 (Pernambuco). Rio de Janeiro: IBGE, 1990.

. Censo agropecuário de 1995/96 (Pernambuco). Rio de Janeiro: IBGE, 1997.

Censos econômicos de 1950 (Pernambuco). Rio de Janeiro: IBGE, 1956.

- Produção Agrícola Municipal: culturas temporárias e permanentes (Pernambuco, Alagoas, Sergipe e Bahia), 1973-80. 
GUEDES, L.C.A. Condicionantes da distribuição de renda na agricultura de Goiás em 1980. Piracicaba, 1992. 108p. Dissertação (Mestrado) - Escola Superior de Agricultura "Luiz de Queiroz", Universidade de São Paulo.

HOFFMANN, $\mathbf{R}$ Componentes principais $\mathbf{e}$ análise fatorial. Piracicaba: ESALQ/USP, 1994. (Série Didática, n.90, $3^{\mathrm{a}}$ ed.). 37p.

A dinâmica da modemização da agricultura e a distribuição de renda em 157 MRH do Brasil. Revista de Economia e Sociologia Rural. Brasilia, v. 30, n. 4, p. 271-290, out./dez. 1992.

; KAGEYAMA, A. Modernização da agricultura e distribuição de renda no Brasil. Pesquisa e Planejamento Econômico, v.15, n.1, p.171-208, abr. 1985.

; KASSOUF, A. Modernização e desigualdade na agricultura brasileira Revista Brasileira de Economia, v. 43, n.2, p.273-303, abr.jjun. 1989.

JANVRY, A. de. Social structure and biased technical change in Argentina agriculture. In: BISWANGER, H.P.; RUTTAN, V.W. Induced inovations. The Johns Hopkins University Press, 1978. p.297-326.

JORGENSON, D.W. Teste de teorias alternativas de desenvolvimento em economia dualista. In: Araújo, P.F.C.; SCHUH, G.E. Desenvolvimento da Agricultura: natureza do processo e modelos dualistas. São Paulo: Pioneira, 1975. cap.2, p.137152.

LANILLO, R.F. Caracterização da estrutura de produção agropecuária do estado do Paraná. Piracicaba, 1984. 177p. Dissertação (Mestrado) - Escola Superior de Agricultura "Luiz de Queiroz", Universidade de São Paulo.

LEWIS, W. A. Economic development with unlimited supplies of labour Manchester School, n.22, p.3-42, 1954. 
MARX, K. O Capital. Crítica da Economia Política. Rio de Janeiro: Civilização Brasileira,1971. v.I-II. (Livro Primeiro : O processo de produção do capital).

MEDEIROS, C.B. et al. Estrutura dos processos produtivo e administrativo do setor agropecuário em Pernambuco. In: CONSELHO DE DESENVOLVIMENTO DE PERNAMBUCO. Cadernos do Conselho de Desenvolvimento de Pernambuco. Recife: CONDEPE, 1970. (Série I, Agricultura, v.5).

MELO, M.L. de. Bases geográficas dos problemas do Nordeste. In: IBGE. Revista Brasileira de Geografia, v. 24, n.4, out./dez. 1962.

MELO, P.C.T. Considerações sobre a produção de tomate industrial em Pernambuco. Recife: IPA, 1983.

MESQUITA, O.V.; GUSMÃO, R.P.de; SILVA, S.T. et al. Modemização da agricultura brasileira. Revista Brasileira de Geografia, v.39, n.4, p.3-65, out./dez. 1977.

PAIVA, R.M. Modemização e dualismo tecnológico na agricultura: uma reformulação. Pesquisa e Planejamento Econômico, v.5, n.1, p.117-161, jun. 1975.

REDWOOD, J. Evolução recente da agricultura nordestina: principais tendências e transformações, 1950-70. Recife: MINTER / SUDENE / POLONORDESTE / OEA, 1983.

RUTTAN, W. Teorias de crescimento em estágios, modelos em economia dualista e política de desenvolvimento agrícola. In: ARAÚJO, P.F.C.; SCHUH, G.E. (Coord.). Desenvolvimento da agricultura: natureza do processo e modelos dualistas. São Paulo: Pioneira, 1975. cap.2, p.153-172.

SABBAG, W. A pequena propriedade no Agreste: estudo das transformações, 195070. Recife: PNPE-IPEA/UFPE, 1979. 
SABBAG, W. Contribuição ao estudo da olericultura: uma análise da produção e dos determinantes de sua expansão em Pernambuco, 1950-80. Recife, 1984. 221p. Dissertação (Mestrado) - Universidade Federal de Pernambuco.

SERPE (Serviço de Estatística de Pernambuco). Anuários estatísticos de Pernambuco: 1949-80.

SILVA, J.G. da; KAGEYAMA, A. Emprego e relações de trabalho na agricultura brasileira: uma análise dos dados censitários de 1960, 1970, e 1975. Pesquisa e Planejamento Econômico, v.13, n. 1, p.235-266, abr.1983.

TARSITANO, M.A.A. Análise da agricultura mato-grossense, 1970-85: modernização, desconcentração da terra e mão-de-obra. São Paulo, 1990.1 152p. Tese (Doutorado) - Fundação Getúlio Vargas.

TAVARES, M. da C. Acumulação de capital e industrialização no Brasil. Rio de Janeiro, 1974. 182p. Tese (Livre Docência) - Faculdade de Economia e Administração, Universidade Federal do Rio de Janeiro.

TRONCOSO LEONE, E. Modernização e distribuição de renda no Estado da Bahia em 1980. Piracicaba, 1988. 152p. Dissertação (Mestrado) - Escola Superior de Agricultura “Luiz de Queiroz", Universidade de São Paulo.

ZANCHET, M.S. Estrutura agrária, modemização e distribuição de renda na agropecuária catarinense em 1980. Piracicaba, 1990. 122p. Dissertação (Mestrado) Escola Superior de Agricultura “Luiz de Queiroz", Universidade de São Paulo. 